\title{
KAZIMIR MALEVICH: APPROACHING THE NEW SYSTEM
}

$$
\text { by }
$$

Irina Lyubchenko

Master of Fine Arts, University of Ottawa, Ottawa ON, 2010

Bachelor of Technological Education, University of Toronto, Toronto ON, 2013

Bachelor of Fine Arts, Ryerson University, Toronto ON, 2007

\author{
A dissertation \\ presented to Ryerson University and York University \\ in partial fulfillment of the \\ requirements for the degree of \\ Doctor of Philosophy \\ in the joint program of \\ Communication and Culture
}

Toronto, Ontario, Canada, 2020

(C) Irina Lyubchenko, 2020 


\section{AUTHOR'S DECLARATION FOR ELECTRONIC SUBMISSION OF A DISSERTATION}

I hereby declare that I am the sole author of this dissertation. This is a true copy of the dissertation, including any required final revisions, as accepted by my examiners.

I authorize Ryerson University to lend this dissertation to other institutions or individuals for the purpose of scholarly research.

I further authorize Ryerson University to reproduce this dissertation by photocopying or by other means, in total or in part, at the request of other institutions or individuals for the purpose of scholarly research.

I understand that my dissertation may be made electronically available to the public. 


\title{
Kazimir Malevich: Approaching the New System \\ by Irina Lyubchenko \\ Doctor of Philosophy in the joint program of \\ Communication and Culture \\ Ryerson University \\ 2020
}

\begin{abstract}
This dissertation examines Kazimir Malevich's art and writing with a view to establishing that they combine a strain of strict methodological reductionism with an equally well-marked esotericism. It strives to prove that although this feature of Malevich's work was common among vanguard artists and thinkers, there are also highly idiosyncratic qualities in the way Malevich reconciled these two threads. An ensuing goal of this work is to propose how to complete an unfinished 1927 film script by Kazimir Malevich titled "Artistic and Scientific Film—Painting and Architectural Concerns-Approaching the New Plastic Architectural System.”

The question regarding the confluence of science and mysticism in Malevich's workthe primary concern of this dissertation—requires tracing in the artist's art and writings the presence of ideas belonging to these worldviews traditionally considered to be antithetical to each other. This dissertation establishes Malevich's relationship with mysticism and strains of thought that resemble scientific content and approach. Among the latter, this work investigates Malevich's interest in the geometry of the fourth dimension, draws parallels between the artist's concern for visualizing infinity and the problems of set theory, and examines the role of imaginary numbers in Malevich's worldview. To complete the analysis of Malevich's exploration of the concept of space prominent in the aforementioned mathematical themes, this dissertation examines the artist's interest in investigating the space of the cosmos. It also establishes that Malevich's ideas were not only influenced by the scientific advancements in electromagnetism but also by the theories of thermodynamics, which together with the former
\end{abstract}


relay a view of the world where all processes, organic and inorganic, are understood as the product of the transformation of energy. In Cubism and Futurism: Spiritual Machines and the Cinematic Effect, R. Bruce Elder draws attention to the early twentieth-century thinkers' view of cinema as an electromagnetic machine. This dissertation examines Malevich's relationship with the cinematic art and its reception in Russia during Malevich's most productive years. This work concludes with having satisfied its larger objective: to envision a possible scenario of how Malevich's unfinished script could unfold. It contains the copy of the original script, its proposed finale, and an essay that outlines how my investigation of Malevich's intellectual landscape informed the decisions involved in inferring the concluding shot sequences of the artist's only cinematic work. 


\section{Acknowledgements}

This dissertation was prepared with the generous support of the Joseph-Armand Bombardier Canada Graduate Scholarship, using funds provided by the Social Sciences and Humanities Research Council of Canada, Ontario Graduate Scholarship, and Rogers Fellowship in Communication and Culture.

First and foremost, I would like to thank my supervisor, R. Bruce Elder, without whose support and intellectual stimulation this dissertation would not have been possible. Prof. Elder's incredible wealth of knowledge and encyclopedic erudition, coupled with electrifying enthusiasm for scholarship, have been an endless source of inspiration. Bruce Elder and his wife Kathryn included me into their rich world of culture in every form, whether it was the realm of ideas, art, or the enjoyment of international cuisine. Being a part of this world elevated my understanding of how neatly interwoven living and studying culture are as processes: an invaluable lesson for a scholar of culture. As I embark on my post-dissertation journey, I am infinitely grateful for my supervisor's continued mentorship.

Additionally, I am immensely thankful for all the support and advice of my committee members: Isabel Pedersen, who always found time to offer pertinent and insightful suggestions, and Seth Feldman, whose sense of humour and wise comments cheered me up and steered my thoughts in the right direction.

One of the most memorable experiences I have had during my doctoral work was my Foreign Study at the Stedelijk Museum Amsterdam, supervised by Frank van Lamoen. The latter's enthusiasm and depth of inquiry in the questions of avant-garde art's history and theory propelled my research and ignited my creative practice with new ideas. I also would like to thank the staff of the Stedelijk Museum's library and archives-Willem van Beek, Esther Brakenhoff, 
Bart Brouns, Maartje Janssen, Marly Hendricks, Michiel Nijhoff, and Niek Stafleu—whose professionalism and friendliness created the most enriching intellectual environment.

My sincere gratitude also goes to Catherine Richards, my MFA supervisor, who was at the roots of my fascination with Kazimir Malevich's work. My many fruitful dialogues with Prof. Richards, who is always a source of inspiration for being more daring and trusting one's sense of creative intuition, made me into the artist and the scholar I am today.

This dissertation truly was a group effort: my mother Natalia Lyubchenko spent many hours in galleries documenting important exhibitions of Russian avant-garde art, acting as my ambassador in Russian libraries, finding references and passages in rare books that are difficult to find anywhere else; my partner and lifelong friend Michael Portnoy shared his technical expertise, knowledge of higher-dimensional geometry, and programming; and George Izraelian made this project feasible by generously offering the use of his Oculus Rift VR gear. Last but not least, I would like to thank my friends and family, who have provided tremendous support throughout my writing this dissertation. 


\section{Table of Contents}

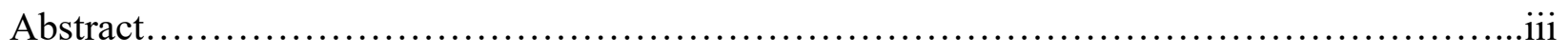

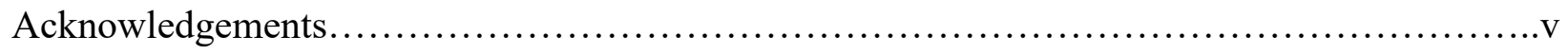

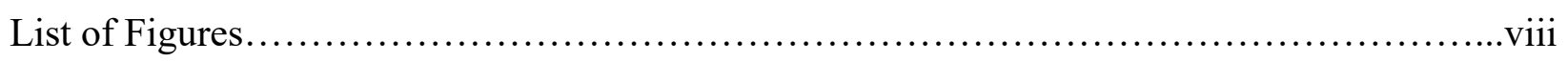

List of Appendices..................................................................

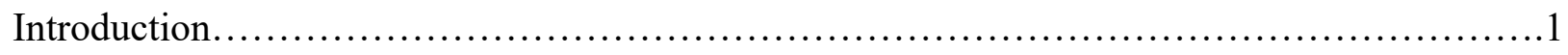

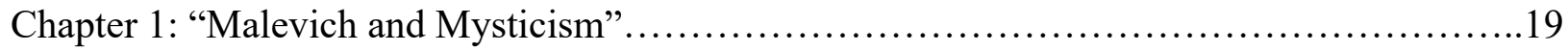

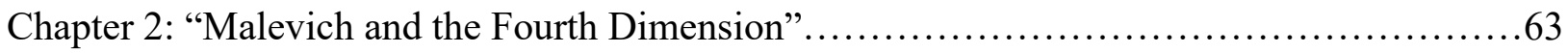

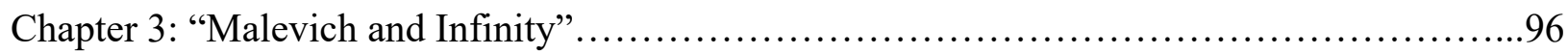

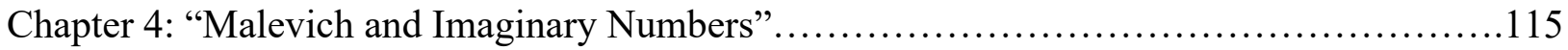

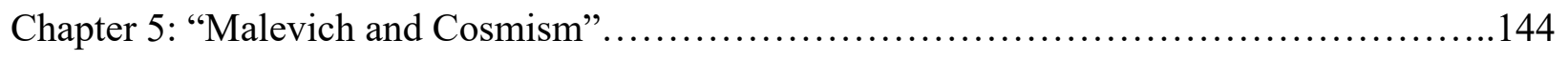

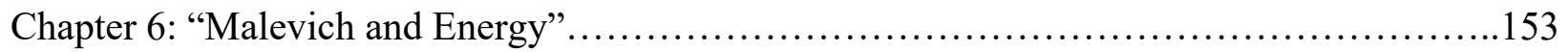

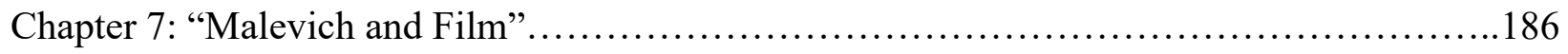

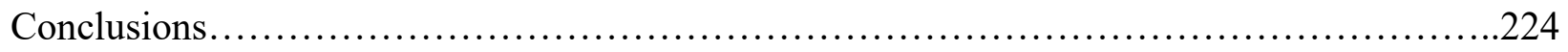

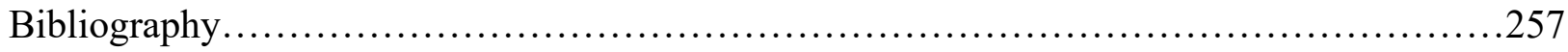


Figure 4.1: Polar form of a complex number

Figure 4.2: Florensky's depiction of the reversed side of reality

Figure 4.3: Kazimir Malevich, The Graph of the Movement of Creative Units in Infinity, 1919-1923 (left); A three-dimensional Cartesian coordinate system (right).

Figure 4.4: Malevich's (right) and Florensky's (left) conceptions of the space(s) (my interpretation).

Figure 4.5: Favorsky's cover image for Florensky's Mnimosti v Geometrii (left);

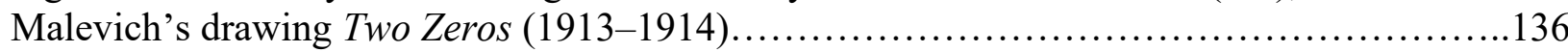

Figure 4.6: Kazimir Malevich, Suprematist Mirror, 1923.................................137

Figure 6.1: Kazimir Malevich, Environment that inspires suprematists ("reality"), photographs that accompany Malevich's essay Introduction to the Theory of the

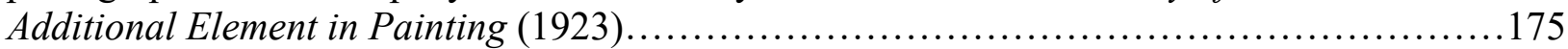

\section{List of Appendices}

Appendix A: "Realizing Kazimir Malevich's Unfinished Film Script"

Figure A.1: Excerpts from Kazimir Malevich's script “Artistic and Scientific FilmPainting and Architectural Concerns-Approaching the New Plastic Architectural

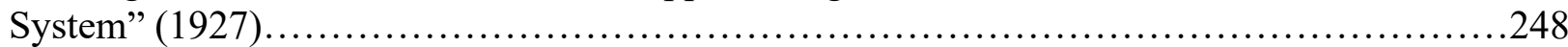

Figure A.2: Stills from the video depicting consecutively overlaid transparencies with drawings of figures from Malevich's script, as seen in Figure A.1. The video can be watched here (password: Malevich): https://vimeo.com/366396037.

Figure A.3: Cube in anaglyph Stereo 3D. Please turn the page horizontally and view with the included glasses.

Figure A.4: Four-dimensional cube in anaglyph Stereo 3D. Please turn the page horizontally and view with the included glasses.

Figure A.5: Four-dimensional architecton in anaglyph Stereo 3D. Please view with the included glasses.

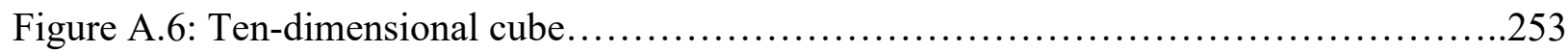

Figure A.7. Screenshot of the Virtual Reality scene of a four-dimensional architecton.........255

Figure A.8: Screenshot of the Virtual Reality scene of a four-dimensional architecton (close-up) 256 


\section{Introduction}

\section{Dissertation Objectives:}

In this dissertation, I examine the art and writing of Kazimir Malevich (1879-1935) with a view to establishing that they combine a strain of strict methodological reductionism with an equally well-marked esotericism. I strive to prove that although this feature of Malevich's work was common among vanguard artists and thinkers there are also highly idiosyncratic qualities in the way Malevich reconciled these two threads. An ensuing goal of this work is to propose how to complete an unfinished 1927 film script by Kazimir Malevich titled "Artistic and Scientific Film - Painting and Architectural Concerns - Approaching the New Plastic Architectural System.”

\section{Genealogy of Dissertation's Objectives:}

The art of Kazimir Malevich accompanied me throughout my life. I first saw his paintings as a six-year old child, at the retrospective of Malevich's work at the Tretyakov Gallery where, according to my mother who took me there, I offered my first philosophical interpretation of the Black Square. When I began making my own art, the basic geometric shapes in primary colours often entered the frames of my photographs, films, and videos. If Malevich knew of this development, he would have said that my artistic body was infected with the additional element of Suprematism. I began noticing the persistent presence of Malevich's legacy in my work during my MFA studies at the University of Ottawa. Becoming conscious of the effects his art had on my imagination prompted me to read Malevich's extensive writings. At once poetic and purportedly scientific, Malevich's idiosyncratic prose intrigued me: the writings' unique style and content were like nothing else I had read before. Several of Malevich's essays are intended for educational purposes and are more declarative and lucid by comparison to the artist's more personal philosophical texts that started speaking to me only recently, years after I first 
encountered them. Among the instructional writings was Die Gegenstandslose Welt (The World as Non-Objectivity), a book that consisted of two essays, "Einführung in die Theorie des additionalen Elementes der Malerei" (Introduction into the Theory of the Additional Element in Painting), and "Suprematismus" (Suprematism), edited and published in German by Walter Gropius and Lazlo Moholy-Nagy as an eleventh book in the Bauhaus book series Bauhausbücher. These essays were one of the last of Malevich's attempts to disseminate his utopian vision internationally and, as such, were intended to attract the attention of readers who were also aided by useful diagrams and accompanying drawings. They reinforced my intent to study Malevich's oeuvre more closely, until I was able to fully relate to the world of ideas that enriched this artist's life.

The first intellectual puzzle that drew my attention upon reading Malevich's The World as Non-objectivity turned out to be a result of poor translation, as I subsequently learned from consulting the text in its original Russian language. Most versions of Malevich's Bauhaus texts were translated to English from the German 1927 publication, since the original Russian texts were not published until 1998. For example, in the 1964 Modern Artists on Art: Ten Unabridged Essays, a publication that contained Malevich's "Suprematism" essay (one of two essays in the Bauhaus book), the editor Robert L. Herbert writes that "the entire text was translated by Howard Dearstyne from the German (the Russian manuscript has not been uncovered) ... ."1 The English translation of the first sentence of "Suprematism" states,: "Under Suprematism I understand the supremacy of pure feeling in creative art."2 It is difficult not to associate "the supremacy of pure feeling" with Romanticism and the primacy of the inner self to which the proponents of this movement ascribed. The words of the hero of Ludwig Tieck's Romantic novel Franz Sternbald's Wanderings come to mind: "Not these trees not these mountains do I wish to 
copy, but my soul, my mood, which governs me just at this moment." ${ }^{3}$ Even though an argument can be made in relation to the parallels that run between Romanticism and Suprematism, the emotional subjectivism that "the primacy of pure feeling" encompasses is in striking contradiction with the rational investigations of the first essay in the Bauhaus book titled "Introduction to the Theory of the Additional Element in Painting." This essay is a careful examination of artistic styles aimed at determining the mechanisms of their evolution. Malevich does not study emotions and inner feelings of artists as variables that affect the development of artistic styles. This contradiction prompted me to consult Malevich's texts in Russian, where I learned that Malevich used the word “ощущение" that can mean both, feeling and sensation. While the first meaning of the Russian word connotes an emotional landscape of an individual, the second — refers to the perceptual apparatus or human sensorium and, as such, has no connection with Romantic notions of the primacy of the inner world. This investigation into the meaning lost in translation brought me to the realization that Malevich's scholarship may still have gaps and misunderstandings, and that I may be able to fill them.

This initial examination of the Russian word “ощущение” that combines objective and subjective meanings, sensation and feeling respectively, was a prelude to the larger theme of my investigation of the co-existence of scientific and esoteric, mystical ideas in Malevich's work. The aforementioned essay "Introduction to the Theory of the Additional Element in Painting" highlights the effects of the surrounding environment on the nervous system of an artist, who transforms painterly forms though serving as a medium between the environment and the body of a painting. The essay is infused with Darwinian ideas and explains the formation of stylistic traits in art as a result of the artist's interaction with his or her environment. One of the reasons why Suprematism came to existence, according to Malevich, was the development of aviation 
and the ability to observe familiar objects from unfamiliar perspective that revealed them in flattened, simplified geometric forms. This theory of Suprematism's origins was in remarkable contrast with Malevich's account of how he "discovered" Black Square, his first Suprematist painting completed in 1915 . He writes:

The midnight of art broke through. Fine arts are sentenced to exile. The artist-idol—a relic of the past. Suprematism squeezes the entirety of painting into a black square on a white canvas. I did not invent anything. I just felt the night inside me and in it I saw the new, which I called Suprematism. It expressed itself as a black plane in the shape of a square. ${ }^{4}$

I began to wonder how Malevich can simultaneously describe his art as a visual language that developed in accordance with evolutionary laws and as a revelation that appeared to the artist in a trance-like state. My interest in tackling this question resulted in this dissertation.

Simultaneously with my becoming intellectually absorbed with the evolutionary theories of art discussed in Malevich's Bauhaus book, I learned of the existence of the unfinished 1927 film script titled "Artistic and Scientific Film - Painting and Architectural Concerns Approaching the New Plastic Architectural System.” At the end of the 1950s, Malevich's script was discovered in Berlin and reached the attention of Hans Richter, the avant-garde filmmaker, who Malevich hoped would turn his vision into a film. ${ }^{5}$ Richter was unsuccessful in his attempts to realize Malevich's cinematic project. ${ }^{6}$ I became convinced that if I learn to understand how scientific and occult inspirations coalesced in Malevich's imagination, I would be able to finish this artist's only cinematic project — an undertaking that to my knowledge no other artist besides Hans Richter attempted to accomplish. Now, nearing the completion of my doctoral studies, I can confirm that grasping the intricate ways in which scientific reasoning intertwined with esoteric notions is central for understanding the art and writings of Kazimir Malevich. In this resulting documentation of my investigations, for the first time in one body of work, I bring together analyses of Malevich's oeuvre in relation to scientific ideas borrowed from 
mathematics, physics, biology, tectology (a precursor of systems theory), and rocket science among others, while highlighting the close ties these ideas have with the mysticism and creativity in this artist's synthetic system of thought.

In this project, I aim at creating a kaleidoscopic vision of Malevich's philosophy and practice of art, highlighting the complex ways in which science, technology, and esoteric doctrines stimulated this artist's thinking. This important topic has not received sustained attention from the scholars of Malevich. Exceptions are the insightful analyses of Charlotte Douglas, whose book Swans of Other World: Kazimir Malevich and the Origins of Abstraction in Russia, and her numerous articles, such as "Evolution and the Biological Metaphor in Modern Russian Art" and "Energetic Abstraction: Ostwald, Bogdanov, and Russian Post-Revolutionary Art," revealed the origins of Malevich's mysticism in the scientific and philosophical ideas infused with esoteric strains of thought. The writings of the leading specialist in the Russian $20^{\text {th }}$ century avant-garde, John E. Bowlt, were an enormous resource for my dissertation and provided a holistic portrait of Russian artistic culture on the cusp of the $20^{\text {th }}$ century. Bowlt's Moscow \& St. Petersburg 1900-1920: Art, Life and Culture of the Russian Silver Age was instrumental for my finding close associations between Malevich's artistic journey and that of the Russian Symbolists known for mystical explorations. In Bowlt's essay “Esoteric Culture and Russian Society," I learned of Malevich's frequent visits to the cabaret Stray Dog, which was also a favourite place of P.D. Ouspensky — an insight that allowed me to build a stronger understanding of how Malevich, who despised reading, acquired knowledge of Ouspensky's theories of the fourth dimension. Another source of encyclopedic knowledge of the intricate relations between art, science, technology, and spirituality were the three volumes written by my supervisor, R. Bruce Elder: Harmony and Dissent: Film and Avant-garde Art Movements in the Early 
Twentieth Century, DADA, Surrealism, and the Cinematic Effect, and Cubism and Futurism:

Spiritual Machines and the Cinematic Effect. These studies contain vast knowledge of the time period pertaining to my study, and it would be difficult to highlight any specific ideas that were important for my writing. For the sake of concision, I will list only a few of the themes that these books brought to my attention. Harmony and Dissent's Part 2 outlines the variety of forms spirituality took in the Russian culture of the late nineteenth and early-twentieth century, elucidating the presence of occult motives in Constructivism and Suprematism. DADA, Surrealism, and the Cinematic Effect provides an illuminating analysis of the genealogy of avant-garde art. It pictures the rise of the vanguard art as instigated by the collapse of a modernity that was crushed under the seemingly unbreakable postulates built on the principles of calculative reason. This volume also brought to my attention set theoretical problems of Georg Cantor. As it will be discussed in more detail further in this introduction, Cubism and Futurism revealed to me the extent to which Malevich's work aligned with electrologic art as defined by Marshall McLuhan, Renato Barilli, and R. Bruce Elder. In their respective writings, McLuhan, Barilli, and Elder among other ideas discuss the effects of technological paradigms on imagination, creative expression, and the perception of reality. Taking into consideration that Malevich's most productive years were marked by an incredible attention to electric technologies in Soviet Russia, looking into the theories that reveal non-objective, anti-perspectival art and process philosophies as inspired by the electric paradigm becomes a necessity; McLuhan's, Barilli's, and Elder's accounts of the electrologic worldview's genealogy are excellent companions for this investigation.

When it comes to writing individual chapters, the collection of essays The Occult in Russian and Soviet Culture, edited by Bernice Glatzer Rosenthal, enriched my understanding of 
the wide range of occult beliefs that infused Russian culture during the period of Malevich's active years. I would like to highlight the seminal work on the interpretation of the fourth dimension in the arts by Linda Dalrymple Henderson titled The Fourth Dimension and nonEuclidean Geometry in Modern Art. This groundbreaking study offers a detailed history of the concept's visualizations by mathematicians, such as Charles Hinton, and artists throughout the $20^{\text {th }}$ century. The chapter "Transcending the Present: The Fourth Dimension in the Philosophy of Ouspensky and in Russian Futurism and Suprematism" informed my understanding of the importance of Ouspensky's notions of higher emotions, higher intellect, intuition and mystical wisdom for Malevich and, as such, was instrumental in my crafting the narrative for the chapter "Malevich and the Fourth Dimension," where I follow in the steps of Henderson's important work, building on the arguments offered there. Similarly, the book Naming Infinity: A True Story of Religious Mysticism and Mathematical Creativity, the only work on the Russian mathematicians Egor Luzin, Dmitri Egorov and Pavel Florensky’s association with the Name Worshipping movement, was indispensable in my preparing the chapter "Malevich and Infinity," as it portrayed a rich moment in the history of mathematics when religious practices stimulated scientific work, bringing to the fore the link between science and spirituality that this dissertation traces. Nikolai Firtich's article “Rejecting ‘The Sun of Cheap Appearances': Journey Beyond ‘Zero’ with Kručenych, Malevič, Belyj, Jakobson and Jean-Luc Godard” is a rare work on Malevich's zero philosophy that establishes close ties between Malevich's zero symbolism and that of Andrei Bely. Firtich's analysis inspired me to locate the origins of Malevich's theories of the beyond in the work of Florensky, who undoubtedly influenced Bely's prose. A detailed account, and the first in English, of the esoteric evolutionary philosophy of Nikolai Feodorov offered in Georg M. Young's book The Russian Cosmists: The Esoteric Futurism of Nikolai 
Fedorov and his Followers confirmed my conjecture that Malevich was among those well acquainted with Feodorov's theories. The chapter "Imagining the Cosmos" in Asif A. Siddigi's The Red Rocket's Glare: Spaceflight and the Soviet Imagination presents an insightful overview of how the possibility of space travel inspired early twentieth-century Russian writers and artists to create science-fiction films, novels, and art works that experiment with the utopian dream of interstellar voyage. Both, Young's and Siddigi's brief but perceptive discussions of Malevich's work in relation to Russian Cosmism and space flight, respectively, were illuminating and rich sources that contributed to my chapter "Malevich and Cosmism." Julia Vaingurt's excursion into Aleksei Gastev's biomechanics in her book Wonderlands of the Avant-Garde: Technology and the Arts in Russia of the 1920s made it possible for me to outline organic and mechanistic interpretations of thermodynamics in early Soviet culture and conclude that Malevich subscribed to the former. Vaingurt's book and Douglas' paper "Energetic Abstraction: Ostwald, Bogdanov, and Russian Post-Revolutionary Art," together with Elder's Cubism and Futurism: Spiritual Machines and the Cinematic Effect, laid the foundation for my chapter "Malevich and Energy."

In developing the narratives of my chapters, close reading primary sources has been especially revealing and was essential for my study. Since some of the intellectual connections I established in my dissertation have not been made before, such as Malevich's possible interest in set theories and theories of imaginary numbers, I relied extensively on close readings of Malevich's writings and authors whose works I believed to be related. I am infinitely grateful for having access to Malevich's collected writings in five volumes, a publication made possible by the great work of one of the leading scholars of Malevich, Aleksandra Shatskikh. Another avenue for access to Malevich's original works was my archival research at the Stedelijk Museum Amsterdam, where I had the rare opportunity to exchange ideas with the head 
researcher of Khardzhiev-Chaga archive, Frank van Lamoen. Last but not least, I made it imperative to use any opportunity to experience the art of Kazimir Malevich in person and visited galleries and museums that had this artist's works on display. In particular, I would like to mention one of the richest exhibitions of Malevich's work titled Malevich (Tate Modern, London, 16 July-26 October 2014, also shown at the Stedelijk Museum Amsterdam, 18 October 2013 - 2 February 2014) that I visited in London's Tate in 2014.

\section{Chapters' Overview:}

The question regarding the confluence of science and mysticism in Malevich's work-the primary concern of this dissertation - requires tracing in the artist's art and writings the presence of ideas belonging to these worldviews, traditionally (as an aftermath of modernity's reductive methods) considered to be antithetical to each other. I began my explorations of Malevich's intellectual life with establishing this artist's relationship with mysticism in this dissertation's first chapter titled "Malevich and Mysticism." Materialism and positivism injected into the intellectual lives of Russian reading population through Voltaire, Diderot, and Rousseau, combined with the hardened regime of Orthodoxy, created a spiritual void that made alternative belief systems particularly inviting. This chapter explores mysticism as the search for spiritual renovation through practices marginalized by organized religion and studies its relevance for Malevich's philosophy of art through the writings of Vladimir Soloviev and Henri Bergson for whom experience of ultimate reality via art was one of the central philosophical themes. The concepts of darkness, void, abyss, and desert are often present in Malevich's writings and appear in Christian, Hindu, and Buddhist mystical teachings. These introvertive experiences believed to grant the knowledge of higher realities are examined in relation to Soloviev's notion of totalunity and Bergson's vision of reality as flux. These thinkers' proposition to synthesize scientific 
forms of knowledge with the knowledge received through intuition addresses the main question of this dissertation by outlining major philosophical ideas on the confluence of science and mysticism that undoubtedly influenced Malevich's worldview. This knowledge of Malevich's mystical leanings was to serve as a background against which the artist's scientific principles were to stand out in a more clearly defined manner. However, working on this chapter revealed that mysticism in Russian thought of the late nineteenth and early twentieth century was tightly interwoven with scientific notions. This notion is best expressed in Soloviev's advocacy for the reliance on what he called "intellectual intuition," an approach to living that combines the faculties of reason and creativity, or an "an integral knowledge as a synthesis of empiricism, rationalism, and mysticism."7

Having investigated Malevich's relationship with mysticism required me to consider the artist's strains of thought that resemble a scientific content and approach. Malevich's interest in the geometry of the fourth dimension, which was a popular concept at the time and inspired many artists of the early twentieth century, is well documented in Linda Dalrymple Henderson's book The Fourth Dimension and Non-Euclidean Geometry in Modern Art. Malevich did not hide his concern for hyperdimensional space geometry as many of his paintings refer to the fourth dimension of space in their titles. It was clear to me that mathematical ideas, such as hyperspace geometry, influenced Malevich's work. This conjecture that investigation of mathematical ideas is a fruitful endeavor when it comes to interpreting Malevich's art and writing can be supported by the artist's contemporary Guillaume Apollinaire's claim that "most of the new painters are mathematicians without knowing it."

Having strong evidence in support of Malevich's interest in hyperspace, reinforced my decision to begin the exploration of Malevich's intellectual attraction to mathematical ideas with 
the chapter "Malevich and the Fourth Dimension" and the implications of the popularity of this mathematical concept on Malevich's oeuvre. A short historical overview of the genealogy of the geometrical idea of the fourth dimension is followed by a discussion of the interpretations of the concept in the occult circles. The concept of the fourth dimension lent itself to esoteric interpretations. The proponents of spiritualism suggested that the fourth dimension was the domain of souls, while Theosophists proposed that it was an astral plane that human spirit alone could reach. This chapter explores hyperdimensional space geometry through both the lens of mathematical science and counter-scientific interpretations of spiritualism and Theosophy. With scientists, such as Alexander Butlerov and Johann Karl Friedrich Zöllner, adhering to esoteric beliefs, the border between the different approaches to understanding the fourth dimension is difficult to define. Malevich's art and writings demonstrate the artist's awareness of the plethora of ideas associated with hyperspace. This chapter concentrates on Malevich's synthetic approach to the geometry of the fourth dimension in connection to the ideas of Charles Hinton and Pyotr Ouspensky.

Upon completing the chapter "Malevich and the Fourth Dimension," I began investigating whether Malevich's common use of the word "infinity" in his writings was indicative of his fascination with set theory, a branch of mathematics of the infinite that dominated science at the turn of the centuries and beyond. The chapter "Malevich and Infinity" proved that there was ground for my conjecture. It begins with the historical overview of the concept of infinity, so central to Malevich's work, concentrating on its genesis and its further development in the Western world. Attempts to treat actual infinity in mathematical terms, have played a major role in the crisis of modern reason, ${ }^{9}$ leading to the advancements in Russian mathematics that arguably have affected Malevich's conception of the role and the possibilities 
of painting. Russian mathematicians Nikolai Luzin, Dmitri Egorov, and Pavel Florensky grappled with the questions posed by set theory, a branch of mathematical logic established by Georg Cantor in the second half of the nineteenth century. ${ }^{10}$ This chapter examines how Luzin, Egorov, and Florensky's struggle to gain the knowledge of the infinite parallels that of Kazimir Malevich. As in the previous chapter, the strong ties between scientific principles and mystical ideas are established. Here, it is accomplished through revealing the creative inspiration the aforementioned mathematicians received from their engagement with the condemned religious movement of Name Worshippers.

While collecting material for the "Malevich and Infinity" chapter, I discovered the work titled Mnimosti v Geometrii (Imaginaries in Geometry) written by Pavel Florensky, one of the mathematicians labouring on the problems of set theory. At the same time, at the KhardzhievChaga archive of Malevich's documents at Stedelijk Museum Amsterdam, I found Malevich's drawing The Graph of the Movement of Creative Units in Infinity that displayed a graph of a function drafted as if it was behind the $\mathrm{x}, \mathrm{y}, \mathrm{z}$ axes usually used for plotting mathematical objects in a three-dimensional space on a two-dimensional surface. Florensky's interpretation of imaginary numbers as existing on the reverse side of reality echoed this drawing's content and prompted me to develop this line of investigation further, resulting in the chapter titled "Malevich and Imaginary Numbers" - an analysis of the role of imaginary numbers in the work of Kazimir Malevich. This chapter argues that the philosophical implications of "mnimosti" in geometry, related to the mathematical concept of complex numbers (numbers that have an imaginary part), have been paramount for the development of Malevich's convictions in the existence of a hidden reality. Imaginary numbers are puzzling mathematical entities, whose contradictory nature intrigued not only mathematicians but also artists and writers. The spatial 
interpretation of imaginary numbers, ${ }^{1}$ in which they are conceived of as geometric rotation operators, inspired Malevich interested in new conceptions of space, such as those offered by the theories of non-Euclidian geometry and a geometric fourth dimension. Pavel Florensky's interpretation of imaginary numbers sought the unified knowledge of space. Florensky's treatment of space as the fundamental unit of geometric analysis led him to conceptualizing complex space as the reverse side of reality, the underbelly of the perceptible world. In Dante's Divine Comedy Florensky found the germ of non-Euclidian geometry, a discovery that prompted him to revive Aristotelian-Ptolemaic-Dantean cosmology. This chapter investigates the connections between the theories of imaginary numbers as explicated by Pavel Florensky and the art of Kazimir Malevich which, as I argue, is in dialogue with these theories.

From the aforementioned investigations it became apparent that for Malevich grasping new conceptions of space was the underlying primary motivation behind his artistic and philosophical works. Whether it is mystical experiences of being one with the universe or penetrating the hidden reality of the fourth dimension, knowing the abyss of the infinite or theorizing how to reach the underbelly of the known world, the idea of space is omnipresent in Malevich's oeuvre. To complete the analysis of Malevich's exploration of this concept, it was a natural step to examine this artist's interest in investigating the space of the cosmos. Making this intellectual leap from the theory of space to the practice of space flight was not difficult as Malevich prepared for future extraterrestrial habitation by designing architectural constructions. The confidence and seriousness of intent with which the artist undertook this planning supports my conjecture that Malevich was aware of Konstantin Tsiolkovsky's ground-breaking

\footnotetext{
${ }^{1}$ One of such spatial interpretations was offered by the mathematician William Rowan Hamilton, who developed the idea of the quaternion in the late nineteenth century; for further detail, please see: William Rowan Hamilton, Elements of Quaternions (London: Longmans, Green \& Co., 1866).
} 
achievements in the new field of rocket science, which this scientist founded at the beginning of the twentieth century. The chapter "Malevich and Cosmism" explores how faith in technological progress combined with the utopian aspiration to escape the confines of Earth transformed science fiction into what many believed to be a scientific fact. Malevich's convictions that space would be conquered were grounded in the ideas of two prominent thinkers who provided theoretical and practical support for the artist's preparations for the imminent space travel. Nikolai Feodorov's "common task" to eliminate death and settle all those resurrected beyond Earth must have prompted Malevich to begin exploring options for a Suprematist architecture in space. Konstantin Tsiolkovsky's revolutionary foundation of the principles of rocket science served as a scientific ground for otherwise fantastical ideas. This chapter investigates unorthodox philosophies, such as Feodorov's Cosmism and Tsiolkovsky's panpsychism, and their principal role in the development of what is considered a purely scientific field of rocket science and space exploration. Malevich's Suprematism, a spatial visual philosophical system, is in dialogue with these systems of belief.

During my PhD studies, I worked as a research assistant for my supervisor, R. Bruce Elder, one of whose projects was a publication of a new volume within the series of books on cinema and its paramount effects on the earlier forms of artistic expression, such as painting and poetry. Presented in a kaleidoscopic web of intricate connections with a variety of ideas, this new book, titled Cubism and Futurism: Spiritual Machines and the Cinematic Effect (2018), argues that the themes explored by the Futurist and Cubist artists were symptomatic of a new age instigated by a shift in worldviews from the mechanical to the electromagnetic conception of reality. I could not help but notice that disregard for linear perspective, the aspiration to capture the dynamism of life, and a denunciation of calculative reason — concerns explored by the artists 
examined in Elder's recent book—were also central for Malevich, whose Suprematism, according to the artist, was the next evolutionary stage of artistic development, following Cubism and Futurism. Together with Marshall McLuhan's Understanding Media (1964) and Renato Barilli's The Science of Culture and the Phenomenology of Styles ([1991], 2012), the two works that are in dialogue with Cubism and Futurism: Spiritual Machines and the Cinematic Effect, Elder's 2018 book had a tremendous effect on my view of Malevich's ouevre. I began considering the search for renewed spirituality and new conceptions of space- the themes I discussed in the chapters on mysticism, fourth dimension, infinity, imaginary numbers, and Cosmism - as symptoms of an electrologic age, manifestations of the changing worldview. There was no doubt that I had to probe the body of Malevich's work for the presence of electromagnetic strains of thoughts.

My consultations with primary and secondary sources revealed that Malevich's ideas were not only influenced by the scientific advancements in electromagnetism but also by the theories of thermodynamics, which together with the former relay a view of the world where all processes, organic and inorganic, are understood as the product of the transformation of energy. The resulting chapter "Malevich and Energy" highlights the importance of the concept of energy in Malevich's work; by consulting the writings of Wilhelm Ostwald and Alexander Bogdanov, widely read by the Russian public at the time, it investigates how the science of thermodynamics entered the range of Malevich's philosophical concerns. The occult strains of Ostwald's science termed "energetics" are examined, followed by the analysis of electromagnetic ideas in Malevich's oeuvre in relation to the aforementioned works by McLuhan, Barilli, and Elder.

In Cubism and Futurism, Elder draws attention to the early-twentieth-century thinkers' view of cinema as an electromagnetic machine that shapes light and, therefore, shapes electricity, 
transforming the film theatre into an electromagnetic space. ${ }^{11}$ After studying Malevich's intellectual connection with the concept of energy, exploring the artist's relationship to film gained additional relevance, beyond my initial interest in the artist's unfinished film script (the completion of which also required engaging with Malevich's view of cinema). The following chapter, "Malevich and Film," examines the artist's relationship with the cinematic art and its reception in Russia during Malevich's most productive years. The changing views of cinemafrom its Symbolist conceptualization as the "kingdom of shadows" to the Futurist appreciation of film as the most suitable form of art to express the dynamism of modern life, and, finally, to the Soviet leaders' realization of cinema's potential as a propaganda tool—are reflected in Malevich's art and writing. The chapter on Malevich and film offers a detailed account of the artist's developing perspectives on film theory and practice. It outlines the artist's vision for cinema, which stems from the criticism of figurative, narrative works in favour of abstracted and non-objective films, such as Hans Richter's Rhythmus 21. An account of Malevich's intellectual exchange with the master of figurative cinema, Sergei Eisenstein, is followed by an examination of the artist's hopes for establishing a creative dialogue with Hans Richter, with whom Malevich anticipated making a film about the evolution of Suprematist forms.

The dissertation's main body of research consisting in this introduction and chapters titled "Malevich and Mysticism," "Malevich and the Fourth Dimension," "Malevich and Infinity," Malevich and Imaginary Numbers," "Malevich and Cosmism," "Malevich and Energy," and "Malevich and Film," ends with the brief section "Conclusions," outlining the general outcomes of this dissertation and the new projects that stem from it.

Upon completion of the aforementioned chapters, my imagination gained enough creative momentum to envision a possible scenario of how Malevich's unfinished script could unfold. 
Appendix A contains the copy of the original script, its proposed finale, and an essay that outlines how my investigation of Malevich's intellectual landscape informed the decisions involved in inferring the concluding shot sequences of the artist's only cinematic work. 
${ }^{1}$ Robert Herbert, ed., Modern Artists on Art: Ten Unabridged Essays (Nueva Jersey [Estados Unidos]: Prentice-Hall, 1964), 116.

${ }^{2}$ Ibid., 117.

${ }^{3}$ Tim Blanning, The Romantic Revolution: A History (New York: Modern Library, 2012), 25.

${ }^{4}$ Kazimir Malevich, "Our Time is the Age of Analysis..." [1921], in Sobranie sochinenii v piati tomakh [Collected Works in Five Volumes] (Moscow: Gileia, 1995-2004), vol. 2, 30, (translation mine).

${ }^{5}$ Timothy O. Benson and Aleksandra Shatskikh, "Malevich and Richter: An Indeterminate Encounter," October 143 (2013): 59.

${ }^{6}$ Ibid., 67.

${ }^{7}$ Oliver Smith, Vladimir Soloviev and the Spiritualization of Matter (Boston: Academic Studies Press, 2011), 5.

${ }^{8}$ Guillaume Apollinaire, "On Painting," in The Cubist Painters (Berkeley, CA: University of California Press, 2004), 13.

${ }^{9}$ R. Bruce Elder, Dada, Surrealism, and the Cinematic Effect (Waterloo, Ont.: Wilfrid Laurier University Press, 2013), 42.

${ }^{10}$ Loren R. Graham and Jean-Michel Kantor, Naming Infinity: A True Story of Religious Mysticism and Mathematical Creativity (Cambridge: The Belknap Press of Harvard U Press, 2009), 5.

${ }^{11}$ R. Bruce Elder, Cubism and Futurism: Spiritual Machines and the Cinematic Effect (Waterloo, Ont.: Wilfrid Laurier University Press, 2018), 22-23. 


\section{Chapter 1: Malevich and Mysticism}

\section{Introduction:}

In the last quarter of the nineteenth century, Russia suffered from ideological exhaustion. On one hand this time was marked by the tightening of the Orthodox Church regime - a reaction to Tsar Alexander II's assassination that led to the constraints on freedom of speech and put an end to the intelligentsia's commitment to the institutional church. On the other-by the loss of the belief in Populist ideology that proposed to reform Russia through the education of peasantry and merging of the classes but resulted in the trials of the idealistic leaders of the "going to the people" movement, ironically initiated by the angered peasants themselves. ${ }^{1}$

Russia's literate population, who especially read Voltaire but also Diderot and Rousseau, embraced aspects of the Enlightenment project—religious commitments were attenuated and materialism and positivism were increasingly adopted. ${ }^{2}$ In this environment of spiritual crisis many felt the need for renovation outside of the apparatus of organized religion, partly explaining the importance of mysticism for Russian philosophy at the turn of the centuries.

Understood broadly "as a view that knowledge of reality can be gained in a vital, immediate, intuitive manner that cannot be described in rationalistic or empirical categories,"3 mysticism is treated as a legitimate method for gaining the experience of ultimate reality, sometimes referred to as God, in the philosophies of Vladimir Soloviev and Henri Bergson. This chapter is concerned with the common threads between the philosophies of the aforementioned thinkers and Kazimir Malevich's philosophical system, which I contend reflects some of the major tenets of these rather different but not mutually exclusive philosophies. Without attempting to summarize the vast scope of Soloviev's, and Bergson's systems of thought, I will concentrate on the importance each of the philosophers assigned to mystical experiences and to 
the role of art in grasping the hidden-from-the-senses reality. In this chapter I propose to interpret Malevich's Suprematism as a mystical, artistic approach to knowing the Absolute that Malevich interprets as non-objectivity. I demonstrate that Malevich's philosophy of art is in close intellectual contact with the theories of Soloviev and Bergson, with whom the artist shares the vision of reality as aesthetic and suggests that art is a practice that can unveil ultimate reality perceived as flux.

\section{Mysticism:}

Prior to initiating the discussion of the role of art and mysticism in the philosophies of Soloviev, and Bergson, and elucidating comparable themes in Malevich's Suprematism, I will provide more detail on what is considered a mystical experience. There is an agreement among the scholars of mysticism that the German philosopher, Friedrich Schleiermacher, was one of the most influential for the development of modern mysticism in the nineteenth-century. ${ }^{4}$ According to this thinker, mysticism doesn't belong to any specific religion but is the essence of world religions. It promises an immediate and direct contact with "the infinite world" that stays veiled for habituated senses and a mind muddled in the routine of the everyday. ${ }^{5}$ Broadly defined, using the words of one of the major writers on mysticism Evelyn Underhill, "Mysticism is the art of union with Reality. The mystic is a person who has attained that union in a greater or less degree; or who aims at and believes in such attainment." Evelyn Underhill's book Mysticism (1911) was surpassed in popularity in 1946 with the publication of Aldous Huxley's The Perennial Philosophy. Huxley elaborates on mysticism as a spiritual practice: "Properly practiced, with due preparation, physical, mental and moral, meditation [which Huxley considered to be the 'technique of mysticism'] may result in a state of what has been called 'transcendental consciousness' - the direct intuition of, and union with, an ultimate spiritual reality that is 
perceived as simultaneously beyond the self and in some way within it."

The view of mysticism shared by both, Underhill and Huxley, comprises the school of thought generally known as Perennialism. Sometimes criticized for its underlying essentialism, Perennial philosophy contends that mystical experiences do not dramatically differ among cultures and historical periods, sharing common characteristics. It also assumes that the ultimate reality that reveals itself to the mystics is the same, no matter where and when the mystical experience takes place. ${ }^{8}$ This view of mysticism was especially popular in the beginning of the $20^{\text {th }}$ century when it was disseminated not only by the proponents of such occult doctrines as Theosophy but also by the representatives of a more analytical, scholarly approach to its study, such as William James. In his seminal book The Variety of Religious Experiences, James identifies ineffability and noetic quality as two main features of a mystical experience:

No adequate report of its contents can be given in words. [...] its quality must be directly experienced; it cannot be imparted or transferred to others. [...] mystical states are more like states of feeling than like states of intellect. No one can make clear to another who has never had a certain feeling, in what the quality or worth of it consists.

Although so similar to states of feeling, mystical states seem to those who experience them to be also states of knowledge. They are states of insight into depths of truth unplumbed by the discursive intellect. They are illuminations, revelations, full of significance and importance, all inarticulate though they remain; and as a rule they carry with them a curious sense of authority for after-time. ${ }^{9}$

In opposition to perennialist position, constructivists emphasize the effects of beliefs, expectations, and cultural, historical and social backgrounds on shaping mystical experiences, claiming that linguistic schema of a practicing mystic predetermines the type of the mystical state he or she can enter. The followers of this tradition devote sufficiently more attention to particularities of the mystical experiences, avoiding generalizations such as the perennialist conviction that there is a commonality between the mystical experiences of Hindus, Christians, and Judaists, for example. ${ }^{10}$ In his essay titled, "The Mystical Illusion," one of the prominent representatives of this school of thought, Hans H. Penner, writes: 
The basic assumption of this essay is that there are no direct experiences of the world, or "between individuals except through the social relations which 'mediate' them." Once this principle has been granted, it does not make much sense to speak of states of "pure consciousness" or experiences not constituted from within a linguistic framework. ... If the principle is firmly held it will follow that, if mystical experiences have any significance in order to explain their significance it will be necessary to locate and explicate the set of relations which mediate them. The thesis of this essay is that "mysticism" is an illusion, unreal, a false category which has distorted an important aspect of religion. ${ }^{11}$

In Mysticism, Mind, Consciousness, Robert Forman provides a strong argument against constructivism. Briefly summarized, it states that constructivist claim that mystical experiences are shaped by expectations does not hold its ground — since there is no mental or sensory intentional object in mystical events there is nothing that can be shaped. The role of language in determining a mystical state is also unclear-mystical events are pre-linguistic and are characterized by "void of conceptions." Mystical experiences often take place prior to any intellectual realization and therefore cannot be affected by any factors that constitute the subject, such as his or her cultural and social background. ${ }^{12}$ Taking into consideration the soundness of Forman's argument, I would like to proceed with the assumption that there is, indeed, a similarity among mystical experiences. Based on this assumption founded on perennialist theories, I can now compare Malevich's accounts with those of other mystics. Drawing such parallels makes it possible to put forward a proposition that Malevich's experiences can be understood as mystical.

\section{Malevich and Mysticism:}

One of the sources of my convictions that Malevich's Suprematism is a mystical, artistic approach to knowing the Absolute, which the artist interprets as non-objectivity, is Malevich's description of the birth of the Black Square. Malevich writes:

Полночь искусства пробила. Изящные искусства приговорены к изгнанию. Художник-кумир пережиток прошлого. Супрематизм сжимает всю живопись в черный квадрат на белом холсте. Я ничего не придумал. Я только ощутил в себе ночь и в ней я увидел новое, которое назвал Супрематизмом. Он выразил себя черной плоскостью в форме квадрата.

The midnight of art broke through. Fine arts are sentenced to exile. The artist-idol—a relic of the past. 
Suprematism squeezes the entirety of painting into a black square on a white canvas. I did not invent anything. I just felt the night inside me and in it I saw the new, which I called Suprematism. It expressed itself as a black plane in the shape of a square. ${ }^{13}$

As this quote suggests, Malevich arrived at the non-objectivity of Suprematism through a mystical experience: the Black Square appeared in Malevich as an alien sensation that visited the artist during an introspective experience. The reference to darkness- "I just sensed the night in me"- is particularly important if we are to make an inference that Malevich experienced a mystical intuition that revealed itself as the black plane, the "royal infant" from which the rest of the Suprematist forms have evolved. While it is possible to imply that Malevich mentions darkness poetically, it is tempting to interpret Malevich's internal night as a hint to the content of ideas that enriched the artist's intellect at the time. In case of Malevich's description of the birth of the Black Square, it may well be that the artist felt an intellectual affiliation with the religious tradition of apophaticism.

According to apophatic theology, a lost tradition of Old Russian Orthodoxy that experienced a revival in nineteenth-century Russia, the nature of God is so ineffable that no existing words or concepts can describe Him. ${ }^{14}$ Via negativa is a mystic's way to God through negation of what God is, ultimately leading to a conceptualization of God as darkness, void, abyss, and desert. It is in this darkness that one can find light—an intuition of which the Tibetan Book of the Dead speaks as "the clear light of the Void" and Dionysius—as "the dazzling obscurity which outshines all brilliance with the intensity of its darkness." ${ }^{15}$ The Upanishads, the ancient texts that contain central ideas of Hinduism, too, refer to the knowledge of the creative cosmic principle, or Brahman, as darkness that nonetheless is spiritually illuminating:

\footnotetext{
They who worship ignorance Enter blind darkness:

They who delight in knowledge Enter darkness, as it were, yet deeper
} 
They who worship non-becoming

Enter blind darkness:

They who delight in becoming

Enter darkness, as it were, yet deeper. ${ }^{16}$

It seems that if we are to comprehend the significance of the concept of darkness for the various schools of mystical thought, we must come to terms with the notion that the void can be understood not as emptiness, but as an infinite fullness. Similarly, layer upon layer of coloured paint eventually produces black, which hides within itself a myriad of possible colour combination. For Malevich, the colour black could have carried an analogous meaning of density, not of "blind darkness." If Malevich has experienced a mystic union with the ultimate reality, in which he became enveloped in darkness of the Black Square, he must have expressed the dazzling light of his revelations in his white paintings, such as White on White.

Malevich's description of coming in contact with the Black Square as a feeling of darkness that arose in the artist's psyche, and its stripped down, laconic nature is in marked contrast with the vivid, baroque accounts of the visionaries for whom the experiences are located in the external reality and not the inner world of a mystic. A thirteenth-century Christian, Mechtild of Hackelborn, provides the following experiences of her visions: "The King of glory once appeared in indescribable splendor in the fullness of his joy, wearing a golden robe embroidered with doves and covered by a red mantle. This garment was open on two sides to indicate that the soul has free access to God." ${ }^{\prime 17}$ Malevich's austere sensation of the non-objective Black Square is far removed from the decadent enjoyment of the sensory stimuli that has enveloped Mechtild of Hackelborn in her figurative vision. One can almost see and feel the reflective surface of the lush fabric that covers the King of glory. This striking difference in the experiences of Malevich and Mechtild of Hackelborn indicates that Malevich's mysticism's relationship to sensory experiences is of another order. In his book, Mysticism, Mind, 
Consciousness, Robert Forman agrees with Ninian Smart's definition of mysticism, which states, "Mysticism describes a set of experiences or more precisely, conscious events, which are not described in terms of sensory experience or mental images." ${ }^{18}$ This definition of a mystical state as an experience that is impossible to describe with the vocabulary associated with the senses, accords with the meaning of the Ancient Greek word $\mu v \omega$ (from which the word "mystical" originates) and translates as "to conceal, to close." ${ }^{19}$ Malevich's Suprematist philosophy agrees with this definition of mysticism, emphasizing that experiencing Suprematist art does not involve any of the senses with which we perceive physical reality—Suprematism is a direct, unmediated communication of pure sensation:

\begin{abstract}
Новое Искусство, как и Супрематизм, выключило лицо человека, как выключили предметноизобразительное $<$ из> азбук<и> китайцы, установив другой знак передачи тех или других ощущений. Так как ощущают в последнем исключительно чистое ощущение. Таким образом, знак, выражающий то или другое ощущение, не является образом ощущения. Кнопка, пропускающая ток, не есть образ тока. Картина не является действительным изображением <лика>, ибо такого лика нет.

Отсюда философия Супрематизма не рассматривает мир, не осязает его, не видит, но только ощущает.
\end{abstract}

The New Art, as well as Suprematism, turned off human face, as the Chinese switched off the objectfigurative from their alphabet, setting another sign for the transmission of those or other sensations. Because they feel in the latter an exceptionally pure sensation. Thus, the sign expressing this or that sensation is not a representation of sensation. A button that transmits a current is not an image of the current. The picture is not a real image of the face, for there is no such face.

Hence the philosophy of Suprematism does not inspect the world, does not feel it, does not see it, but only senses it. ${ }^{20}$

Interestingly, Malevich's vocabulary, with which the artist attempts to describe his ineffable experiences, relies on the lexicon of the Christian mystics, such as Meister Eckhart and points to its origins in Neoplatonic thought of such figures as John Scottus Eriugena. In the ninth century, the theologian, philosopher, and poet, John Scottus Eriugena, used the word "desert" to speak of the "No-thingness" of God. In late biblical texts, this harsh empty no-land was considered imbued with possibilities to find God. ${ }^{21}$ For Meister Eckhart, one of the most prominent German mystics who initiated the vernacular language to speak of mystical states, 
desert was a synonym for his idiosyncratic and complex term, "ground," which simultaneously alludes to the physical ground, the base of an object, and the abstract ground, or the essence of a thing. Rupturing beyond the physical limitations of things was a central concern for Eckhart, who wrote: "All our perfection and holiness rests in this: that a person must penetrate and transcend everything created and temporal and all being and go into the ground that has no ground."22 If we turn to Malevich's elucidation of his experiences painting Suprematist shapes, we find striking affiliations with the concept of desert just mentioned. Malevich relies on the concept of a desert on many occasions, emphasizing the non-sensory encounter with this spiritual entity:

Но удивляет меня, что ищущие отправляются на кладбище, но никогда не ищут в пустоте. Всюду изведали люди и пророки все щели головы своей, но не изведали пустоты простынь пустыни. Я ощущаю дыхание пустыни и ставлю живописную супрематическую плоскость в новую жизнь.

But it surprises me that the seekers go to the cemetery, but they never search in the void. People and prophets everywhere scrutinized all the cracks in their heads, but they did not experience the emptiness of the desert sheets. I feel the breath of the desert and put the painterly suprematist plane into a new life. ${ }^{23}$

Искусство вышло к пустыне, в которой нет ничего, кроме ощущения пустыни. Художник освободился от всех идей - образов и представлений и проистекающих от них предметов, и всей структуры диалектической жизни.

Art came to the desert, in which there is nothing but a sense of desert. The artist has freed himself from all ideas - images and representations and the resulting from them objects, and the entire structure of dialectical life. ${ }^{24}$

Белые поля - это не поля, обрамляющие черный квадрат, но только ощущение пустыни, ощущение небытия, в котором вид квадратообразной формы является первым беспредметным элементом ощущения.

White fields are not the fields that frame the black square, but only a sensation of a desert, a sensation of non-existence, in which a variant of a square-shaped form is the first non-objective element of sensation. ${ }^{25}$

Таким образом, на беспредметной пустыне Искусства воздвигнется новый мир ощущений, мир Искусства, выражающий все свои ощущения формой Искусства.

Thus on the non-objective desert of Art, a new world of sensations - the world of Art, which expresses all its sensations through the form of Art- will be erected. ${ }^{26}$

Besides being saturated with the use of the word "desert," biblical language is populated by references to another seemingly empty space - the abyss. Around the twelfth century, in 
contrast to its earlier derogatory meaning, this term began to be used in a positive sense by

Cistercians, a religious order of monks and nuns that originated in France, around 1098 AD. John

Tauler, a disciple of Eckhart, developed a theology of the abyss, in which the abyss from which

all came to life merges with the abyss created from it — the human and the divine become One:

"The abyss draws the abyss into itself." ${ }^{27}$ As it will be mentioned in the chapter on Malevich and mathematics, the artist experiences his Suprematism as an abyss: "I saw myself in space, hidden in dots and bands of colour; there among them I sank into the abyss." 28 And elsewhere:

At the moment, a person's path lies through space; suprematism, the semaphore of colour - in its infinite abyss. The blue colour of the sky is conquered by the suprematist system, broken through, and went into the white as a true real representation of infinity and therefore is free from the colour background of the sky. $^{29}$

Мы на руле аэропланов, на дне и гребне морей, среди клокочущих бездн пространства должны внимательно строго смотреть за движением и с застывшим лицом идти в пустыню.

We are on the helm of airplanes, at the bottom and crest of the seas, among the bubbling abysses of space, we must carefully watch the movement and with a stiff face go to the desert. ${ }^{30}$

Я прорвал синий абажур цветных ограничений, вышел в белое, за мной, товарищи авиаторы, плывите в бездну, я установил семафоры супрематизма. Я победил подкладку цветного неба, сорвал и в образовавшийся мешок вложил цвета и завязал узлом. Плывите! Белая свободная бездна, бесконечность перед вами.

I broke through the blue lampshade of colour restrictions, walked out into the white, follow me, fellow aviators, swim into the abyss, I installed semaphores of suprematism. I defeated the lining of the coloured sky, tore it and put the colours into the formed bag and knotted it. Swim! White free abyss, infinity before you. ${ }^{31}$

Through relying on the language often used by Christian mystics, Malevich seems to

communicate the sensation of non-objectivity that in contemporary theories of mysticism is referred to as pure consciousness event (PCE). Walter Stace, the author of the seminal text Mysticism and Philosophy, distinguishes between "extrovertive mysticism” characterized by perceiving unity with reality and "introvertive mysticism" - non-spatial awareness of a void or "pure consciousness." 32 It is this latter experience that seemed to have stimulated Malevich for the development of the non-objective language of Suprematism. 
However, these two types of mystical experiences are often understood as an extension of one another. The quiet state of introvertive mysticism, such as sama $\bar{a} h i^{33}$ can become prolonged and expanded if a mystic learns to maintain "pure consciousness" along with the full use of the human faculties, entering the state of sahaja samādhi. Malevich's project to restructure the physical reality according to the tenets of Suprematism acquires a new meaning if we consider that this artist's insights could have shared many characteristics with those of other mystics. Then, the introvertive mystical experience that revealed the bliss of non-objectivity to Malevich could be analogous to the state of samāadhi and the extrovertive sahaja samädhi - to the acquiring the state of non-objectivity that erases all boundaries between beings, assimilating into the One. Malevich describes the latter condition of oneness in the following way:

Let us assume that in many thousands or millions of years humanity will attain omniscience, hence, will reach the state of being everywhere. What will this moment be like? There will be nothing to comprehend and nothing to know, and, obviously, there will be nothing to do. The world is open, and its entire being stands in knowledge, the universe in all its greatness and infinity of its creations will move according to its eternal law of motion, and already all its movement is a part of my knowledge and its every phenomenon is infinitely calculated. Having attained such perfection, we will reach God, namely the image that humanity has predetermined in its legends or in actuality. Then, the beginning of a new divine inactivity, non-being, disappearance of personhood will arrive, for the humanity will enter into that greatest image of its perfect predestination. ${ }^{34}$

For Malevich, the utter goal of Suprematism is to rebuild the perception apparatus of human beings in such as a way as to enable them to perceive the world as it really is, as "milk without the milk bottle"; to sense it in its non-objective nakedness devoid of utilitarian constructions of the mind that make the distinction between objects and subjects necessary in the first place:

Двигаясь в общем течении Искусства, освобождающегося от предметности как мироосознания, в тысячу девятьсот 13 году я пришел к форме квадрата, которая была встречена критикой как ощущение полной пустыни. ... Жутко и мне было расстаться с миром образным, волей и представлением, в котором жил и который воспроизводил и принимал за действительность бытия. Но чувство легкости тянуло меня и довело до полной пустыни, которая стала без-образной, но только ощущением, и это стало содержанием моим.

Moving in the general flow of Art, freed from objectivity as a way to perceive the world, in the year of 1913, I came to the form of a square, a feeling of total desert, which was met with criticism. ... It was also terrible for me to part with the figurative world, the will and the representation in which I lived and which I 
reproduced, and accepted for the reality of being. But the feeling of lightness beckoned me and brought me to a total desert, which became non-objectivity, a sensation alone, and it became my content. ${ }^{35}$

Here is how a Buddhist scripture Digha Nikaya describes the attainment of various levels of altered states by a practitioner of samatha meditation:

By the transcendence of all conceptualizations of form, by the disappearance of conceptualizations based upon sense-data, by paying no attention to conceptualizations of manifoldness, having attained to the sphere of infinite space [the practitioner] remains therein, thinking space is unending. By entirely transcending the sphere of infinite space, having attained to the sphere of infinite consciousness [the practitioner] remains therein, thinking 'consciousness is infinite'. By entirely transcending the sphere of infinite consciousness, having attained to the sphere of nothing at all [the practitioner] remains therein, thinking 'there is nothing'. By entirely transcending the sphere of nothing at all, having entered the sphere of neither conceptualization nor non-conceptualization, [the practitioner] remains therein. By entirely transcending the sphere of neither conceptualization nor non-conceptualization, having attained the cessation of sensation and conceptualization, [the practitioner] remains therein. ${ }^{36}$

Taking into account the discussion of Malevich's interest in the concept of infinity of space and of the mind, coupled with the aforementioned analysis of Malevich's encounter with the desert of the Black Square, it becomes difficult to overlook the striking parallels between the descriptions of a Buddhist practitioner's altered states and Malevich's writings on the nonobjectivity of Suprematism. Without claiming that there is any direct influence of the teachings of Christian, Hindu, and Buddhist mystics on Malevich's work, I do, however, want to stress the commonalities between the various introvertive mystical experiences briefly discussed here and those of Malevich. The consistent affinities that Malevich's art and writing have with the practices of the aforementioned mystics, prompts a suggestion that Malevich arrived at Suprematism through a mystical encounter with his own consciousness in its pure, non-objective state - an experience the artist developed into a visual language of Suprematism, the "new realism" of which was to train the senses to perceive the underlying objectlessness of one's own self and the external world; to reach what in Indian and Tibetan Buddhist tradition is called sahaja samādhi - "a recognition of the identity of spirit and matter, subject and object," when there is "no sacred or profane, spiritual or sensual, but everything that lives is pure and void." 37 
To acquire a more nuanced understanding of Malevich's mysticism I propose to consult religious philosophy of Vladimir Soloviev, whose ideas on spirituality infused with his vast knowledge of mystical writings, have inspired artists and thinkers of Malevich's time and beyond. In particular, I would like to concentrate on Soloviev's insistence on the possibility of knowing ultimate reality through the use of intuition and his conviction that art plays a fundamental role in this epistemological undertaking — a point of view he shared not only with Malevich, but also with Henri Bergson, whose philosophy I will turn to in the latter part of this chapter.

\section{$\underline{\text { Soloviev and Mysticism: }}$}

In 1901, Leo Lopatin, Vladimir Soloviev's close friend and a professor of philosophy at the University of Moscow, held a lecture in commemoration of Soloviev who passed away one year earlier. During the lecture, Lopatin shared his conviction that in the last twenty-five years Soloviev certainly was "the most original philosopher in the whole of Europe." Lopatin notes that among Vladimir Soloviev's most profound intellectual faculties was his unprecedented ability to synthesize seemingly incompatible ideas into an organic philosophical structure.

Soloviev is a theist as he accepts the notion of God as the only source of all created life, and he is a pantheist in his understanding of all beings gradually becoming permeated with the Divine Wisdom. He is a mystic in his ideas on the intuitive basis of the knowledge of God, and he is a rationalist in the ways he treats speculative problems of philosophy. Soloviev is an idealist in how he comprehends the inner essence of things, and he is a realist in considering space and time as possessing independent reality. ${ }^{38}$ It is not surprising that one of his followers Sergei Bulgakov noted:

Thanks to the multifaceted nature of his philosophy, the name of Solovyov unites people from a variety of spiritual pasts and presents - philosophers and poets, sociologists and natural scientists, Marxists and decadents, priests and laymen, the right and the left. Every person finds his own road to him, receives answers to his own questions, distinguishes his or her favorite motif within the sonorous chord. ${ }^{39}$ 
It can be said that in his system of thought, Soloviev reached the total-unity of ideas. It is as if his philosophy served as a theoretical model of unity he hoped would become realized in the final stage of humankind's history_- "the total mutual interpenetration and free solidarity of spiritual and material, ideal and real, subjective and objective factors and elements of the universe. ${ }^{" 40} \mathrm{In}$ Soloviev, the project of arriving at the aforementioned total-unity, which brings to mind Malevich's aspiration to grasp the world in its non-objective form, can only be achieved through a synthesis of available ideas on how to approach the reality of lived experiences. Kazimir Malevich's striving towards scientific approach to studying the development of art (his bacteriological method expounded on in "Introduction to the Theory of the Additional Element in Painting," for example) and his emphasis on the role of intuition in artistic processes can thus be understood in relation to the synthesizing impulse witnessed in Soloviev's thought.

Soloviev's synthetic philosophy stems from his conviction that only through the union of intellect and intuition can one gain "integral knowledge" of reality and become aware of one's divine wholeness. The philosopher envisions a path for humanity in which every member of society approaches lived reality through reliance on "intellectual intuition"- a holistic use of all the human faculties that include not only rational thinking but also the creative impulse. Soloviev emphasizes the possibility of instilling positive change on reality through affecting convictions that dwell in human minds. ${ }^{41}$ This predilection towards active transformation of lived experience brings Soloviev's philosophy closer to that of the Russian cosmist, Nikolai Feodorov. While the latter proposes active transformation of nature through scientifically altering the course of its evolution, the former suggests altering the world by practicing creativity—human beings are not only the created, they are also creators, imbued with the theurgist impulse to materialize thought. In the community of people who probe the world with intuitive reason, which is the synthesis of 
rationality and creative intuition, economic, political and spiritual bonds within society develop into an organic unity characterized by the shared common goal of its citizens - to find meaning in life. ${ }^{42}$

The current state of affairs, according to Soloviev, is such that human beings have learned to disregard intuition in favor of calculative reason, severing human contact with the hidden spiritual reality and denying access to the integral knowledge of the world. Soloviev's insistence on legitimacy and actuality of intuition is related to his criticism of rationalism and neo-Kantianism, which enforce metaphysics in which human consciousness can only be concerned with the phenomenal reality. However, according to Soloviev, noumenal knowledge does enter the mind - a contact made possible through the faculty of intuition, or as he often terms it, faith. The philosopher differentiates between the external knowledge that relies on the observation of phenomena and the internal knowledge, whose subject is the underlying essence of things, Kantian "thing(s)-in-itself":

1) In external knowledge or objective knowledge ... we have knowledge only of the practical relationships between actual beings, or their external interaction.

2) With internal experience ... we have knowledge not only of relationships, but of some actual psychological essence, namely our own. Unmediated knowledge of a being is possible only in terms of internal experience, or that which I call essential knowledge. ${ }^{43}$

Soloviev's emphasis on the necessity of integral knowledge proposes to synthesize external and internal knowledge into an epistemological system that relies on both, empirical data and intuitive insights. Malevich's inner encounter with the Black Square - "I did not invent anything. I just felt the night inside me and in it I saw the new, which I called Suprematism. He expressed himself as a black plane in the shape of a square" 44 — can be understood as an experience instantiated by an intuitive insight, leading to what Soloviev terms internal knowledge. The nonobjective vision of Black Square can be interpreted as the unmediated knowledge of the silent 
interiority of Malevich's own self, through which, according to the mystical writings discussed earlier, one gains the knowledge of the Absolute.

Soloviev echoes mystical teachings of Hinduism, Buddhism, and those of early Christian mystics in his description of what he defines as internal, unmediated knowledge of one's psychological essence and what in contemporary theories of mysticism is termed "pure consciousness experience." These connections are not accidental— the philosopher was a devoted scholar of mystical works and had traveled to London's British Museum to study Indian, gnostic, and Medieval thought. ${ }^{45}$ It is difficult to ascertain how familiar Malevich was with Soloviev's ideas but the artist certainly shares the philosopher's convictions in the possibility of knowing the noumenal reality through an unmediated knowledge of the self and of the surrounding physical world. His Suprematist shapes, starting with the Black Square, his "milk without the milk bottle," attest to this proposition.

Kazimir Malevich's philosophy in many ways reflects Soloviev's skepticism regarding the well-spread infatuation with science and denigration of all forms of experiences for which no empirical evidence can be found. Some of the earliest expressions of these convictions can be found in his work for the Futurist opera Victory Over the Sun. Through the use of Zaum language invented by Kruchenykh, atonal musical score written by Matyushin, and Malevich's set designs that transformed perception of space, the opera was intended to confront and overthrow calculative reason represented by the Sun that enlightens all with rationality and logic. This early, somewhat violent project of overcoming the rule of reason, can be witnessed in such lines from the opera's text as "We picked up the sun by its fresh roots, They are fatty, smelled of arithmetic." And, elsewhere in the opera's libretto:

With swollen fingers in reddish hairs, the sun has caressed you with the gadfly's persistence: in your soul, a slave has been kissed to death. 
I, fearless,

have born my hatred for daylight through centuries... ${ }^{46}$

Victory Over the Sun, however, is not intended as a proclamation of war on reason; it only points at the weaknesses of relying on intellect alone, mistrusting one's sense of intuition.

Kruchenykh's Zaum was not a celebration of madness but an introduction of a constructive principle with which to unveil ontological reality. ${ }^{47}$ Malevich's alogism, a visual language that preempted Suprematism and developed in parallel with Zaum, which synthesized common vocabulary with nonsensical elements, too, combined figuration and abstraction to challenge the habitual way of perceiving reality. In his personal letters to Kruchenykh, Malevich expressed his growing understanding of how one can simultaneously rely on both, reason and intuition:

We have come as far as the rejection of reason, but we rejected reason because another kind of reason has grown in us, which in comparison to what we have rejected, can be called 'beyond reason' [zaumnyi] which also has law, construction [konstruktsiia], and sense, and only by learning it shall we have work based on the law of the truly new 'beyond reason'.

We have arrived at beyond-reason-ness. I don't know whether you agree with me or not, but I am beginning to understand that in this beyond-reason there is also a strict law which gives pictures their right to exist. And not one line should be drawn without the consciousness of its law, then only are we alive. ${ }^{48}$

Malevich carried his conviction in the fruitfulness of intuitive reasoning throughout his artistic carrier, developing a system of thought that in many ways was in dialogue with that of Soloviev. In "On New Systems in Art," Malevich has placed intuition at the center of his cosmology. Using phrases such as "intuitive wisdom" and "worldly intuition," the artist envisions intuition as an interpenetrating energy for which the artificially created borders between subjects and objects do not exist. The intuitive wisdom's dynamic movement towards self-realization creates human beings who, upon reaching perfection, shed the outlines of their bodies joining in what the intellect calls "brotherly love":

Удобства, о которых человек хлопочет лично для себя, окажутся пустыми. Для мировой интуиции не существует ни культуры, ни человека, ни лошади, ни паровоза, и она ничего не делит на национальное, отечественное, государственное, как делает человек, привесивший на каждый кустик номер о роде, происхождении, вероисповедании и звании. Интуиция ныне уже срывает все номера, но для особых необходимых ей целей, которые разумом рассматриваются как экономическое 
харчевое дело и единство, братство «вечной любви».

The comforts that a human being is bustling about for his selfish reasons will turn out to be meaningless. For the world intuition, there is no culture, no man, no horse, no locomotive, and it divides nothing into a national, domestic, or state, as a person does, adding to each bush a number about gender, origin, religion and rank. Intuition is already tearing down all the numbers, but for the special purposes that are necessary for it, which are considered by the intellect to be an economic affair and solidarity, the brotherhood of "eternal love." 49

Шар земной не что иное, как комок интуитивной мудрости, которая должна бежать по путям бесконечного. ... В бесконечном движении предыдущего вышел новый знак движения - человек, и о покое, удобстве нечего думать, ибо в тот момент, когда человек достигнет или будет достигать видимого совершенства, интуиция выведет из него все человеческое в новый знак, и образ человека исчезнет как допотопный мир.

The earthly ball is nothing but a lump of intuitive wisdom that must run along the paths of the infinite. ... In the endless movement of the past, a new sign of movement has emerged - human, and there is no reason to think of comfort, for at the moment when a human being reaches or about to reach apparent perfection, intuition will distill from him all human characteristics into a new sign, and the human image will disappear as an antediluvian world..$^{50}$

Even though Malevich does not rely on the concept of Soloviev's all-unity when explaining his cosmological views, there is a looming sense of its presence in Malevich's descriptions of intuitive wisdom's disregard for borders, definitions and other human constructs. It is through the teachings of intuition that humankind can learn how to perceive the world as One, or, in Malevich's words, as Non-objectivity.

In Malevich's concept of intuitive wisdom and worldly intuition, one can recognize the face of Soloviev's Sophia (Divine Wisdom). In "Readings on Godmanhood," Soloviev pictures the world as a concrete realization of the Absolute unity and ideal multiplicity. This Being, the lived reality of actually existing things, gains independence and freedom; it is capable of affecting the Absolute, for it simultaneously is both, concrete and ideal. In its unity, this Being, which opposes itself to the Absolute, is Sophia, the world-soul and the ideal humankind, which connects and contains all beings within itself. ${ }^{51}$ However, for the world to participate in the intimate dialogue with the Absolute, it first has to reach the state of the ideal humankind, to embody Sophia, to become Divine Wisdom. For Soloviev, humanity's Fall took place when 
human beings segregated themselves from the rest of the living world and became alienated in their greed and selfishness:

... man, as the spiritual centre of the universe, embraced the whole of nature in his soul and lived its lifeloved, understood, and hence controlled it — now, having asserted his selfhood, having shut his soul off from all things, he finds himself in an alien and hostile world, which no longer speaks to him in an intelligible language, and neither understands nor obeys him.... ${ }^{52}$

In their respective visions of a utopian future, both, Soloviev and Malevich, devote a central role to the actions of human beings, whose perfection leads to all-unity. In fact, one of the most sufficient corrections to Christianity that Soloviev undertook was his reconceptualization of the place of human beings on their path towards salvation. Whereas Christian doctrine teaches that sin entered the world through man, Soloviev contends that evil and discord the concrete reality is permeated with, is the direct result of God's need for diversity. ${ }^{53}$ In Soloviev's cosmological system, plurality of all the forms found in the natural world came to being through God's contemplation of each of the ideal essences separately, affirming their independent existence. This process severs ties with the unity of God, who, through this contemplation, creates real entities from ideal forms. ${ }^{54}$ This intimate connection between posited-out-of-God beings and God, led Soloviev to a conclusion that natural world is "only a different and improper interrelation of the very same elements which constitute the being of the divine world." 55 The world of God and the concrete world "differ from one another not in essence but in arrangement." 56 This conclusion further led to a proposition that through active re-organization of its elements lived reality can become the Kingdom of God-a project that can be accomplished when all matter becomes spiritualized. Through receiving the knowledge of the Divine order, all elements will assume their rightful place within the cosmos.

Spiritualization of matter is fundamentally a creative act, endowing artistic practice with the major role in the quest towards total-unity. In The General Meaning of Art, Soloviev states: 
Для своей настоящей реализации добро и истина должны стать творческою силою в субъекте, преобразующею, а не отражающею только действительность. Как в мире физическом свет превращается в жизнь, становится организующим началом растений и животных, чтобы не отражаться только от тел, но воплощаться в них, так и свет разума не может ограничиться одним познанием, а должен осознанный смысл жизни художественно воплощать в новой, более ему соответствующей действительности.

For its actual realization, the good and the truth must become a creative force in the subject, transforming and not simply reflecting reality. As in the physical world, light turns into life, becomes the constructive cause of plants and animals, not only to be reflected from bodies, but to be incarnated in them, so the light of reason cannot be limited to acquiring knowledge alone, but should artistically embody the apprehended meaning of life in a new, more appropriate for it, reality. ${ }^{57}$

Creativity for Soloviev is a transforming, alchemical force that is capable of not simply mirroring reality but recasting it into something completely new. The energy of sunlight undergoes a complex chemical process that stimulates the growth of plant life. Similarly, knowledge of life gained from experience becomes the inner force responsible for the transformation of artist's materials into new realities. Malevich, too, seeks to gain the knowledge of the world through two incarnations of light: "sunlight, revealing things, and the brightest light — the light of knowledge." 58 On many occasions in his writings Malevich also stresses that the role of an artist is not to replicate nature, which he equates with an act of theft, but to add new forms to the myriad of those already existing:

Природа есть живая картина, и можно ею любоваться. Мы живое сердце природы. Мы самая ценная конструкция этой гигантской живой картины. Мы ее живой мозг, который увеличивает ее жизнь. Повторить ее есть воровство, и повторяющий ее есть ворующий; ничтожество, которое не может дать, а любит взять и выдать за свое (Фальсификаты).

Nature is a living picture, and one can admire it. We are the living heart of nature. We are the most valuable design of this giant living picture. We are its living brain, which multiplies its life. Copying it is stealing, and the one who is copying it is a thief; a nobody who cannot give, but loves to take and pass for his own (Counterfeits). ${ }^{59}$

And, even more succinctly:

Природа есть декорация, а наше творчество увеличение жизни. Мы готовим сознание к принятию больших начал, чем земные.

Nature is a decoration, and our creativity is a multiplication of life. We are preparing consciousness to accept greater beginnings than earthly ones. ${ }^{60}$ 
Interestingly, Malevich's understanding of his creativity as an expansion of life leads the artist to a conclusion that his creative, theurgist acts are akin to those of God. Malevich may be describing his having reached the state of Soloviev's Godman-a semi-divine creator in his own right—when he writes:

The difference between God and man is that God does not have a question for what and why. His goal is life-creation, like my organism moves air. To this I came. A man, who has reached the world will, ceases to be a man. ${ }^{61}$

In the aforementioned statements, Malevich does not only agree with Soloviev on the artistic necessity of creation as an act of birth, an addition to the entities already existing in nature but also manifests the anthropocentric view of the cosmos, in which humankind is at the heart of the universal order and is on its way to attaining the knowledge of the "higher first principles."

Soloviev suggests that the latter knowledge is revealed through art. However, not all artistic activities can lead to this type of revelation. Soloviev differentiates between three types of materialization of beauty in art. Beauty can be concretized in art through a direct or magical contact with noumenal reality that is internally deeply felt by the artist. It can also be experienced through materialization in art of the amplified glimpses of meaning hidden in the everyday - a result of an indirect experience of beauty. And, finally, there is an experience of beauty through reflection - an utterly destructive aesthetic activity that is rooted in mindless mirroring of the absolute ideal in the inadequate human reality. ${ }^{62}$ It is possible to suggest that Malevich's art belongs to the first type of Soloviev's schema for, according to Malevich's own account, the artist encountered Black Square in a deeply felt internal experience. In Soloviev's cosmology, Malevich can be regarded as an epitome of an artist capable of spiritualizing reality through direct experience of the Absolute made possible through reliance on intuitive reason. However, before arriving at such conclusion - that Malevich can be considered the prophesied by Soloviev artist-theurg, who was to restructure reality according to the Divine principles 
(Malevich's Non-objective principles) — it is necessary to address a seeming incongruity between Soloviev and Malevich's cosmological theories: the lack of the concept of beauty in Malevich's writings.

Soloviev understands beauty as a type of unity, alongside goodness and truth. All three categories, as a coming together of various elements, are manifestations of love in a general meaning of the word, whose definition is close to such concepts as harmony and cosmos. ${ }^{63}$ Beauty is a real, actually existing manifestation of love as unity, clarifying Soloviev's insistence on its necessary presence in works of art. Artist's role, in Soloviev's vision, is to create unity out of disparate, alienated elements of lived reality, transforming the world through creativity into a harmonious all-unity.

For Soloviev, the microcosm of artistic form is analogous to the macrocosm of lived reality — both must be characterized by a particular relationship between its elements and the whole. Among these prescribed relations are the mutual reliance of individual elements on one another, constitution of the whole from its parts, and the preservation of individuality amid the members of the whole ${ }^{64}$ Kazimir Malevich, too, sees the creative process as a struggle to create a unity of contrasting elements, harmony out of dissonant parts:

The same creative surface appeared before the artist-creator - his canvas, the place where the intuition builds his world and also the flowing forces of painterly and colour energies are regulated by him in various forms, lines, planes; he also creates forms, individual elements of their signs and achieves unity of contradictions on his painterly surface. Thus the creation of the contrasts of forms brings to being a unified harmony of the body of the construction, without which creation is inconceivable. ${ }^{65}$

Soloviev equates the lack of harmony between the elements with evil: "Any evil can be reduced to a violation of mutual solidarity and the balance of parts and the whole." ${ }^{96}$ Even though Malevich does not operate with such concepts as evil, good, truth, and beauty, the artist agrees with the philosopher that the art's meaning is in creating harmony out of dissonant, contradicting elements. In Soloviev, an artwork that on its painterly surface demonstrates unified harmony is 
an integration of spirit and matter. And, spiritualization of matter is the vector of Soloviev's

entire system:

Идеальное содержание, остающееся только внутреннею принадлежностью духа, его воли и мысли, лишено красоты, а отсутствие красоты есть бессилие идеи. В самом деле, пока дух не способен дать своему внутреннему содержанию непосредственного внешнего выражения, воплотиться в материальном явлении и пока, с другой стороны, вещество не способно к восприятию идеального действия духа, не способно проникнуться им, претвориться или пресуществиться в него, до тех пор, значит, между этими главными областями бытия нет солидарности, а это значит, что у самой идеи, которая именно и есть совершенная солидарность всего существующего, нет еще здесь, в этом ее явлении, достаточно силы для окончательного осуществления или исполнения ее сущности.

The ideal content, which remains only the inner affiliation of the spirit, its will and thought, is devoid of beauty, and the absence of beauty is the impotence of the idea. In fact, as long as the spirit is not able to give its inner content a direct external expression, to incarnate in a material phenomenon and while, on the other hand, the substance is not capable of perceiving the ideal action of the spirit, is unable to become permeated, transformed by it or be transfigured into it, then there is no solidarity between these main areas of existence, and this means that the idea itself, which is the perfect solidarity of all that exists, does not yet have here, in this phenomenon, sufficient strength for the final realization or fulfillment of its essence. ${ }^{67}$

In order to restructure the world so that it resembles the original Divine order of beauty,

harmony, and unity, where all the elements in the cosmos assume their rightful place, matter

should become permeated with spirit, and spirit must necessarily find expression in matter.

Malevich appears to agree with Soloviev's project when he states:

Возможно ли такое разделение, отъединение духа от тела или души, раз тело составляет архитектуру последней (дух и материя разные по весу явления)? По моему предположению, это отъединение сделать нельзя, поскольку наше сознание находится в представлении материи как тела. Но разделение существует, и весь упор человеческого усилия идет к одной силе духовной, через поднятие духа собирается привести все материи в нужное состояние. Отсюда усмотреть возможно то, что материя, приведенная через силу духа, уже одухотворена и потому предполагается жизненной и духовно легкой,- само же физическое разрешение любого вопроса без духовного участия считается безжизненным неодаренным состоянием.

Is such separation possible, the separation of the spirit from the body or the soul, since the body constitutes the architecture of the latter (spirit and matter are different in weight phenomena)? In my opinion, this separation cannot be done, because our consciousness is in the representation of matter as a body. But the separation exists, and the whole emphasis of human effort goes to one spiritual force, through the uprising of the spirit is going to bring all the matter into the rightful state. Hence it is possible to see that matter brought through the force of the spirit is already spiritualized and therefore supposed to be vital and spiritually light, while the physical resolution of any question without spiritual participation is considered a lifeless, ungifted state. ${ }^{68}$

Malevich's philosophy approaches Soloviev's when the artist shares his conviction that through

the "uprising of the spirit" humankind can bring all matter to its "rightful state" of being

spiritualized and therefore_-living and light (for Malevich, lightness or weightlessness are 
fundamentally important characteristics of matter that enable it to escape the forces of gravity and reach the abyss of non-objectivity beyond Earth). Thus, both thinkers consider the spiritualization of matter as state that objective reality must attain before being transformed into the total unity. For Soloviev and Malevich, the world process initiated by nature and continued by humans is an aesthetic process. The world is artistic material that through creativity of humankind can regain its contact with the Absolute, becoming a universal spiritual organism and ultimately leading to the end of the world process, of history.

It is difficult to ascertain the degree to which Malevich was familiar with Soloviev's writings. This short analysis, however, points at intellectual affiliation between these thinkers, who both struggled to reform society through changing the ways of knowing reality. Soloviev and, later, Malevich, were ultimately proposing an epistemological revolution in which humankind's theurgic creativity played a central role. It seems plausible that Malevich's proposition that artists rely on intuitive reason, a method which can lead to gaining awareness of the world in its non-objective state, can be considered a part of the same intellectual striving that prompted Soloviev to insist on the need to obtain integral knowledge of reality and enter the state of all-unity—a condition that, similarly to Malevich's non-objectivity, is characterized by the disintegration of objects.

\section{Bergson and Mysticism:}

French philosopher Henry Bergson (1859-1941) sought to unveil the hidden-from-perception condition of reality as flux, where objects are not bounded by clearly defined limits but, instead, interpenetrate each other in a state of a continuous change. From, roughly, the 1890 s to 1920 s, it is possible to find ideas parallel to those of Bergson in the works of many Russian artists, writers, and thinkers, belonging to a wide range of cultural movements, such as Symbolism, 
Futurism, Acmeism, and Suprematism. ${ }^{69}$ This intellectual affinity between Bergson and most of the prominent Russian cultural figures of the time can to a large degree be attributed to their shared concern regarding the effects of scientific rationalism and determinism on human consciousness, which prompted investigation of integrative modes of knowing that emphasized the role of intuition in granting access to the ceaselessly flowing reality Bergson called duration. $^{70}$

For Bergson, as for Soloviev and Malevich, one of the central philosophical projects is stressing the difference and proposing a synthesis between the scientific forms of knowledge available through the practice of analysis, and those available through intuition and leading to the knowledge of the absolute (the Absolute for Soloviev). In an essay titled Introduction to Metaphysics (1912), Bergson defines scientific method as "going all around [a thing]," implying that there is always a particular position one takes as an observer obtaining relative knowledge of an analyzed object. The other way of knowing entails "entering into [a thing]"-a position that cannot be characterized by any particular viewpoint and therefore incapable of providing any relative knowledge of an object, instead granting an absolute knowledge. Even though stripped of its religious connotations, Bergson's absolute that appears to be recast from its religious predecessor retains some of its characteristics: it is inexpressible through symbolic language, can be revealed in a form of a direct awareness of "all at once in its entirety," perfect in the sense of being "perfectly what it is," and infinite. ${ }^{71}$

Bergson contends that the human mind has a tendency to subject the absolute knowledge of an original experience to the compartmentalizing forces of abstraction and analysis. In what can be interpreted as a criticism of representational mimetic art, Bergson provides an example to this practical affliction of the human mind. He pictures an artist, who, while visiting Paris, makes 
some sketches of Notre Dame. ${ }^{72}$ As long as this artist's aspiration is to copy the appearance of

Notre Dame, the sketches remain the work of an artisan, incapable of offering a genuinely new, original experience:

But disinterested art is a luxury, like pure speculation. Long before being artists, we are artisans; and all fabrication, however rudimentary, lives on likeness and repetition, like the natural geometry which serves as fulcrum. Fabrication works on models which it sets out to reproduce; and even when it invents, it proceeds, by a new arrangement of elements already known. ${ }^{73}$

Bergson suggests that the discussed Notre Dame illustrations, being the "fabrication works" "set out to reproduce," no matter how well executed, are but notes on the experience as a whole and are incapable of granting an intuition of Paris to those who have never visited the city. Even for the artist, who created these drawings, they are but vectors pointing in the direction of an original intuition that inspired the work. ${ }^{74}$ The inner meaning of an original experience, such as the sense of a city an inquisitive tourist acquires, is the absolute infinite knowledge that even an endless myriad of its representations cannot offer.

Bergson offers an analogous example of what intuition is in his discussion of what it means to approach an understanding of the work of a philosopher. A devoted reader eventually reaches the stage of familiarization with the philosopher's thought when they have a fleeting sensation of grasping the idea, the single point this philosopher has been formulating in his entire oeuvre:
In this point is something simple, infinitely simple, so extraordinarily simple that the philosopher has never succeeded in saying it. And that is why he went on talking all his life. He could not formulate what he had in mind without feeling himself obliged to correct his formula, then to correct his correction: thus, from theory to theory, correcting when he thought he was completing, what he has accomplished, by a complication which provoked more complication, by developments heaped upon developments, has been to convey with an increasing approximation the simplicity of his original intuition. All the complexity of his doctrine, which would go on ad infinitum, is therefore only the incommensurability between his simple intuition and the means at his disposal for expressing it. ${ }^{75}$

This brings to mind the distinction between actual and potential infinity discussed in chapter "Malevich and Infinity": the simplicity of the original intuition is akin to the unfathomable absolute infinite that mathematicians (unless they operate within the field of set theory) avoid to 
represent mathematically, picturing infinity as a potentiality consisting of endlessly increasing manifolds. The latter can be compared with the aforementioned complexity of the philosopher's doctrines, which "go on ad infinitum" and with which they attempt to describe the simplicity of the original intuition. In accord with Bergson's ideas, Malevich, parting ways with mimetic representation, seeks to attain the feeling of the actual infinite, the simplicity of intuition of an original experience, all-at-once-in-its-entirety sensation. This striving can be witnessed in the evolution of Suprematism, which entered the stage of the absolute of the white-on-white paintings upon outgrowing its earlier stages of black-and-white and colour Suprematism.

In "Form, Colour, and Sensation," Malevich shares a concern similar to that of Soloviev and Bergson: there is an assumption that methods of science are applicable to art, or, more generally, that scientific analysis is the only reliable method of knowing reality. Specifically referring to Friedrich Ostwald's colour system, Malevich's argument centers on the discussion of a theory that application of colour to form can be guided by scientifically discerned rules, for which, according to Malevich, there is no place in the toolbox of an artist:

Таким образом, все законы, установленные оптикой, основанной на физическом восприятии глазной
системой явлений, могут, конечно, быть введены в знание художника, но пользоваться этими
знаниями в своих творческих работах ему не придется, эти знания для него будут абстрактны. Но
если художник захочет использовать их, то можно смело поручиться, что его картины будут похожи
на ничего не стоящие в художественном отношении произведения великого ученого по цвету
Освальда.

Thus, all laws established by optics, which is based on the physical perception of phenomena by the ocular system, can, of course, be introduced into the knowledge of the artist, but he will not have to use this knowledge in his creative works, this knowledge will be abstract for him. But if the artist wants to use it, you can safely vouch that his paintings will look like artistically unworthy works of the great colour scientist, Ostwald. ${ }^{76}$

Malevich explains that since colour theories describe phenomena related to the structure of the human visual perception apparatus, the use of optical effects is legitimate in such utilitarian applications as, for example, selection of an appropriate wall colour suitable for the size of a room to be painted. The effects of artworks instill changes in the spiritual or psychic system of a 
human being and alter perception of reality in an aesthetic or mystical way. ${ }^{77}$ The rules that guide optical illusions simply do not apply to those that control the effects of art on a psycheart is directed by an intuition of an artist and not by a set of scientific principles:

Следовательно, организм каждого художника обладает внутри себя довольно тонкой по работе лабораторией, которая даст сто очков любой оптической лаборатории, ибо разрешить такую проблему как отношение цвета к форме является немаловажным делом.

Но в действительности эти две лаборатории расходятся или одна другую исключает, и достижения второй для художника могут иметь такое значение, как наука об анатомии для искусства, т.е. никакого значения.

Восприятия физической стороны мира через интуицию, преломляясь в представлениях, не будут совпадать с решением оптической лаборатории. Оптическое восприятие есть рассмотрение явлений, а интуитивное есть ощущение их. Поэтому, если для первого важна форма «как таковая» и цвет «как таковой», для второго ни форма, ни цвет не играют никакой роли, ибо на первый план ставится художником ощущение явлений, а не изображение как зрительное восприятие оптического порядка.

Consequently, the organism of each artist has within itself a rather fine laboratory, which will give a hundred points to any optical laboratory, since to solve such a problem, as the colour-to-form ratio, is no small matter.

But in reality these two laboratories diverge or exclude each other, and the achievements of the second for the artist can have such significance as the science of anatomy for art, i.e. no significance.

Perceptions of the physical side of the world through intuition, refracted in representations, will not coincide with the decision of the optical laboratory. Optical perception is the visual inspection [рассмотрение] of phenomena, and the intuitive is the sensation of them. Therefore, if for the first the form "as such" and the colour "as such" are important, for the second, neither form nor colour play any role, since it is the sensation of phenomena, rather than image as visual perception of the optical order that is foregrounded by the artist. ${ }^{78}$

The Russian word "рассмотрение" (rassmotrenie) refers to not only the process of looking carefully, with an increased effort to see something thoroughly, but also to pondering an issue with the purpose of making an assessment. ${ }^{79}$ The root of the word "смотр" (looking at something as in inspection) discloses a Platonic connection between knowledge and vision: in “рассмотрение," considering something and looking at something are intertwined. This prompts a suggestion that Malevich's use of "рассмотрение" is not accidental - the artist's choice of vocabulary emphasizes the connection between optical vision and analytical thinking. When Malevich speaks of optical perception as looking at phenomena, Bergson's definition of scientific analysis_- "going all around [a thing]"- comes to mind. Malevich's emphasis on the artist's primary goal being communication of sensations and not picturing of phenomena, which 
belongs to the optical order, reminds of Bergson's definition of the role of philosophers: "entering into [a thing]" to grasp it intuitively. In fact, in its attention to dispencing with symbolic representation of reality, Malevich's Suprematism begins to approach Bergson's understanding of metaphysics:

If there exists a means of possessing a reality absolutely instead of knowing it relatively, of placing oneself within it instead of adopting points of view toward it, of having the intuition of it instead of making the analysis of it, in short of grasping it over and above all expression, translation or symbolic representation, metaphysics is that very means. Metaphysics is therefore the science which claims to dispense with symbols. ${ }^{80}$

The absolute knowledge of an object attained through intuition, or "a sympathy by which one is transported into the interior of an object in order to coincide with what there is unique and consequently inexpressible in it," $" 81$ allows access to the dynamic reality hidden by the utilitarian predilections of the human mind.

Bergson considers intuition located in duration, while analysis - in immobility. ${ }^{82}$ Malevich, too, understands the underlying reality as inherently dynamic: "The whole Universe is moving in a vortex of non-objective excitation." ${ }^{83}$ In his scientific analysis of the evolution of artistic forms titled "Introduction to the Theory of the Additional Element in Painting" (and since Malevich's artistic intuitions were antecedent to his analytic insights, Bergson would have approved Malevich's scientific study of art since "It cannot be too often repeated: from intuition one can pass on to analysis, but not from analysis to intuition" $\left.{ }^{\prime 4}\right)$, Malevich notices a historical trajectory in forms' development according to which colour masses seek to liberate themselves from the confines of form and conceptual baggage imposed on them by representational art. Such disintegration of form is accompanied by a release of colour masses' repressed dynamism, and since one of the goals of art, according to Malevich, is to express sensations of universal dynamism, Malevich prescribes annihilation of form as a means to achieve art's goal. Futurists, for example, even though they are able to achieve a dynamic sensation on their canvases, are still 
bound to objective representation characterized by a chaotic distraction of form, whose broken

pieces are not yet fully abstract. In "Futurism, Kinetic and Dynamic" (1929), Malevich

emphasizes that an artwork's elements must co-exist in a state of harmonious balance, which

Futurist painterly explosions of objective reality can only destabilize:

Разница между супрематическим проявлением динамического ощущения и проявлением футуристическим будет в том, что футурист динамическое ощущение проявляет при помощи явлений природы, то есть человека, затем - при помощи движения вещей. Супрематическое проявление ощущения той же силы, наоборот, не проявляет эту силу через какие бы то ни было вещи либо природные явления, а создает особую форму, которой и проявляет ощущаемую силу. Потому картина проявления супрематического динамизма являет собой не хаотичный вид построений динамических элементов вещей, как это мы видим у некоторых футуристов, например у художника Боччони, а видим гармонично выстроенный образ абстрактных элементов.

The difference between the suprematist and the futurist manifestation of a dynamic sensation is such: the futurist expresses the dynamic sensation with the help of natural phenomena, that is a human being, andwith the help of the movement of things. The suprematist manifestation of the sensation of the same force, on the contrary, does not manifest this force through any things or natural phenomena, but creates a special form, which manifests the force being sensed. Therefore, the painterly manifestation of suprematist dynamism is not chaotic in the type of construction of the dynamic elements of things, as we see in it in some of the futurists, for example, in Boccioni, but we see a harmoniously arranged image of abstracted elements. $^{85}$

Malevich's "special forms" are non-objective vessels for the colour masses released from the confines of utilitarian objects. In their movement towards greater dynamism, they evolve towards the ultimate dynamic system of white Suprematism where these "special forms" begin to disintegrate, merging with the absolute. Malevich paints dynamic interior of objects—drops in the ocean of Bergsonian non-objective universal duration.

It seems that the artist agrees with the philosopher that the perception of objective reality as coagulated in many ways is a convention, a useful system of isolation of durations into matter that allows human bodies to survive. This imposed-by-the-human-mind static order, however, hides dynamic non-objectivity:

В ней [в природе] действуют проявления без цели, ума, рассуждения, знания и идеи, она вечное безидейное биение, вне причин и обстоятельств, она <как> возбуждение в первом случае, во втором как беспредметность. Отсюда может существовать и то, что не мыслит... Человек, забравшись в глубь природы, где нет никаких предметов, говорит - там нет жизни... Там нет мысли, там нет $<$ ни > книг, ни движения. Что же тогда там существует? Беспредметность, беспредметная природа. Появление человека в таком обстоятельстве вносит новую реакцию, которая выражается творением предметов, т.е. установление $<$ м $>$ понятий. Реализация таковых понятий создает вещь, предметы. 
Создается то, что называем жизнь. Так создается предметная жизнь понятий, осознаваний, но сущность беспредметная фактически остается незыблемой.

In it [in nature] manifestations act without purpose, mind, reasoning, knowledge and idea, it [nature] is an eternal, non-conceptual pulsation, outside of causes and circumstances, it is excitation in the first case, in the second - non-objectivity. Hence, there can be something that exists and does not think ... A man, penetrating into the depths of nature, where there are no objects, says - there is no life ... There is no thought, there are no books, no movement. What then exists there? Non-objectivity, non-objective nature. The emergence of a human being in this circumstance introduces a new reaction, which is expressed by the creation of objects, i.e. the establishment of concepts. The implementation of such concepts creates a thing, objects. What we call life is created. This creates the objective life of concepts, awareness, but the nonobjective essence actually remains unshakable. ${ }^{86}$

According to Malevich, human conception of life is intimately connected with existence of objects. Malevich, in agreement with Bergson, reverses this notion—-life, in its primordial endless flowing duration, does not require human mind to exist; it endures despite of human mind's attempts to assign static order to it. Unattended by the mind's tendency to impose form and conceptual meaning on surrounding environment, objects melt and become one with the universal flow of energies. Bergson writes:

The distinct outlines which we see in an object, and which give it its individuality, are only the design of a certain kind of influence that we might exert on a certain point of space: it is the plan of our eventual actions that is sent back to our eyes, as though by a mirror, when we see the surfaces and edges of things. Suppress this action, and with it consequently those main directions which by perception are traced out for it in the entanglement of the real, and the individuality of the body is re-absorbed in the universal interaction which, without doubt, is reality itself. ${ }^{87}$

Bergson considers art as a pathway to "reality itself." Interestingly, the philosopher has not developed a systematic theory of art, nor had he delivered dedicated lectures or published any essays specifically on this topic. ${ }^{88}$ However, Bergson's oeuvre is permeated with references to art as a practice that relies on intuition and serves as one of the most convincing applications of Bergson's theories. In art, Bergson finds the proof for the existence of intuition as a faculty of human perception: "That an effort [of intuition] is not impossible, is proved by the existence in man of an aesthetic faculty along with normal perception." ${ }^{89}$ This distinction between normal and aesthetic perception is reminiscent of Malevich's differentiation between visual and psychic 
perceptual systems, where the former is affected by the optical phenomena, and the latter-by mystical insights. In Laughter, Bergson offers one of his most lucid definitions of art:

There is a veil between nature and us ... a veil which is thick for ordinary men, but thin, almost transparent, for the artist and the poet. ... Thus, art has no other object than to set aside the practical useful symbols, the conventionally and socially accepted generalities, in short, all that masks reality from us, in order to place us face to face with reality itself. ... Art is certainly only a more direct vision of reality. ${ }^{90}$

One of the ways in which art is "a more direct vision of reality" than the fields of knowledge that predominantly involve the intellect are, lies in art's resistance to predictabilityone does not know the exact manner in which an idea would materialize into an artistic form prior to its realization; the outcome is always unforeseeable. ${ }^{91}$ Bergson writes:

The finished portrait is explained by the features of the model, by the nature of the artist, by the colours spread out on the palette; but even with the knowledge of what explains it, no one, not even the artist, could have foreseen exactly what the portrait would be, for to predict it would have been to produce it before it was produced - an absurd hypothesis which is its own refutation. ${ }^{92}$

Art shares the characteristic of unpredictability with duration, described by Bergson as "the continuous progress of the past which gnaws into the future and which swells as it advances." 93 When discussing duration of the self - the most available to each human being experienceBergson notes that the constant presence of the past in each moment of existence denies the possibility to relive the same state twice. Affected by the flux of experiences, our personality ceaselessly changes, making it impossible to foresee the future-imagining the new order of elements already perceived cannot provide a prediction of what has not yet been experienced. ${ }^{94}$ This unforeseeable nature of duration that finds expression in the practice of art is in a stark contrast with the methods of science that rely on predictability and repetition. Science determines patterns in phenomena in order to foresee the future outcomes. For Bergson, art is one of the human activities that does not dispense with the unforeseeable but instead embraces it: "In so far as we are geometricians, then, we reject the unforeseeable. We might accept it, assuredly, in so 
far as we are artists, for art lives on creation and implies a latent belief in the spontaneity of nature." 95

Malevich agrees with Bergson on the impotence of calculative methods and scientific predictions when it comes to the events of life: "To be practical means to foresee, and since every prediction is a simple representation or theoretical calculation of the events of being, it can never reveal true reality [подлинность] ехасtly." ${ }^{96}$ Thus, both, Bergson and Malevich, agree that scientific principles must be abandoned when one's aspiration is to grasp reality as flux. Artists, equipped with the sense of intuition, should take command and swim the waters of duration, for they know that "in fact, there is another reality hidden beyond consciousness." 97

Perceiving the other, hidden reality that Malevich refers to in the above paragraph, is often referred to as mysticism. Even though Bergson has been concerned with a possibility of knowing the absolute of duration, he has not referred to this knowledge as mystical until his 1932 book Two Sources of Morality and Religion, where he explored the relationship between the structures of a society and the associated with those structures types of spiritual practices. In this volume, Bergson extends his theories of duration and intuition towards envisioning conditions that can be suitable for the flourishing of human life. True to his didactic method of juxtaposition, Bergson discusses the two types of societies, the closed and the open. The former is that "whose members hold together caring nothing for the rest of humanity, on the alert for attack or defence, bound, in fact, to a perpetual readiness for battle." ${ }^{" 98}$ The members of such a society are controlled by moral obligation, while communicating confidence in the cohesion of their group through the use of static, myth-based religion..$^{99}$

Malevich calls this type of society “общежитие” (obshhezhitie, community housing). In fact, since the artist does not identify an existence of any other type of social organization, it can 
be assumed that human civilization in its entirety falls under this term. In Suprematism as Pure Knowledge, Malevich expounds on how, on its path towards greater knowledge, "общежитие" established the institutions of science, religion, and art, which are in a continuous struggle to denounce each other's claims of having access to truth. ${ }^{100}$ Russian Orthodox religion is founded on the definition that God is tripartite and exists as God, Spirit, and Son. The precision of this definition creates a suspicion in Malevich that the tools of science, the compartmentalizing forces of analysis, are also those of religion. ${ }^{101}$ One of the most important foundations of science is the conviction that it is possible to define a unit of matter. However, the nature of matter for Malevich is as elusive as is the nature of God, bringing the artist to a conclusion that both, science and religion are founded on false premises. ${ }^{102}$ In a Bergsonian spirit, Malevich objects in bewilderment:

Если Христос сказал «не ищите нигде Бога, как только в себе», то и любой техник может сказать,
ищите совершенства вещи только в себе, но как в первом, так и <во> втором этого места
невозможно найти и в себе, ибо где я начинаюсь и где кончаюсь (какие безумные искания
придумало общежитие), но, несмотря на все, человек ищет Бога через два пути.
If Christ said "do not look for God anywhere, but in yourself," then any technician can say, seek the
perfection of a thing in yourself only, but both in one and in the other case, it is impossible to find this
place inside yourself, for [I cannot determine] where I begin and where I end (what a mad inquiry society
[общежитиe] came up with), but, in spite of everything, human beings search for God in these two ways.

Neither religion, nor science, can sense the limitless nature of human spirit, one's inner self. This inability provides the foundation for their existence as institutions that propagate the static model of reality.

Besides revealing the fallacy of science and religion, Malevich also criticizes artists who, under the ideological pressures of “общежитие,” depict symbolical representations of reality forgetting about its non-objective nakedness:

Предметное идейное общежитие творило свою практическую жизнь, но оно не удовлетворилось реальностью, требуя от Искусства другого их состояния символа. Простое яйцо через палитру живописца превращалось в символ Пасхи, стало величайшим событием. 
Продолжая свою предметную “идейную” работу, общежитие направило сознание живописцев и всего Искусства в осознание того, что жизнь последнего только в творении “идейных” символов общежития, что подлинность их не в яйце, а в воображаемом символе. Получилось, что река стала осознавать, что она река для того, чтобы носить лодки, символы человеческой идеи: “Иначе какая же я река, когда не будет на моей спине лодок?”; “Какая же я атмосфера, когда во мне нет аэропланов?”.

Также сказал и художник: “Какой же я буду художник, когда во мне не будет содержания “идейного” предметного общежития?”. “Поэтому я, природа, и я, художник, могу существовать только тогда, когда во мне существует содержание общежития, когда оно в величии своего гнева или милости метает блок смыслов в мое беспредметное без-смыслие”.

The objective, founded-on-ideas-and-concepts society [общежитие] created its practical life, but it was not satisfied with reality, demanding from Art of other, their symbolic state. A simple egg through the palette of the painter turned into a symbol of Easter, it was the greatest event.

Continuing its objective "ideological" work, the society [общежитие] directed the consciousness of painters and the whole of Art to the realization that the life of the latter is only in the creation of "ideological" symbols of society [общежитие], that their authenticity is not in the egg but in an imaginary symbol. It turned out that the river began to realize that it, river, exists in order to carry boats, symbols of the human idea: "Otherwise, what kind of river am I when there are no boats on my back?"; "What kind of atmosphere am I when there are no airplanes in me?".

The artist also said: "What kind of an artist will I be when I do not have the content of an ‘ideological' objective society [общежитие]?”. "Therefore, I, nature, and I, the artist, can exist only when the content of the society [общежитие] exists in me, when in the majesty of its anger or mercy it [society] throws a block of meanings into my non-objective meaninglessness". ${ }^{104}$

In this telling quote, Malevich suggests that it is not only the consciousness of the artist that becomes altered under the demands of what Bergson calls closed society, but also nature itself!

Bergson's open society — a utopian model that the philosopher juxtaposes with his criticism of the closed society, in which members are guided by egoistic principles alone — on the contrary, is "deemed in principle to embrace all humanity." 105 Something that is yet to be attained, the dream of the open society becomes materialized in the lives of those rare individuals who "know that all around intelligence there lingers still a fringe of intuition, vague and evanescent." 106 These mystics, the practitioners of the dynamic religion (and Malevich is certainly one of them), are not afraid to "fasten upon it, intensify it, and above all, consummate it in action, for it has become pure contemplation only through a weakening in its principle, and, if we may put it so, by an abstraction practiced on itself." ${ }^{107}$ Bergson's philosophy begins to approach Soloviev's when he discusses the experiences of a mystic's soul: 
A soul strong enough, noble enough to make this effort would not stop to ask whether the principle with which it is now in touch is the transcendent cause of all things or merely its earthly delegate. It would be content to feel itself pervaded, though retaining its own personality, by a being immeasurably mightier than itself, just as an iron is pervaded by the fire which makes it glow. Its attachment to life would henceforth be its inseparability from this principle, joy in joy, love of that which is all love. In addition it would give itself to society, but to a society comprising all humanity, loved in the love of the principle underlying it. ${ }^{108}$

Bergson's vision of open society where each of its members loves the other, a generosity learned from the experiences of duration, is in striking similarity with Soloviev's Godmanhood. If the latter is a stage of the creative evolution of humankind on the path towards reaching the state of all-unity, which, as it was demonstrated earlier, in many ways resembles Malevich's concept of non-objectivity, Bergson's open-society is the furthest point of the human evolution the philosopher discusses. His vision of the future of humankind lacks the grandiosity, radicalism, and optimism of either, Soloviev's or Malevich's - their anthropocentrism provides confidence that all human beings can become mystics, artists, theurgists and godmen capable of restructuring the world through creativity. In fact, Malevich was so inspired by his vision of the future that he began to prepare humankind for the coming of non-objectivity by gradually assimilating human beings to its presence — an intention most noticeable in his architectural projects and sketches of intergalactic habitats. Bergson, on the other hand, wrote Two Sources of Morality and Religion - his most prominent text that elucidates the philosopher's views on the relationship between human flourishing and social structure — in the atmosphere infused with acute anxiety associated with the rise of Nazism in Germany. It is not surprising then that Bergson's writing of this period lacks the utopian enthusiasm of the Russian thinkers, and, instead of the promise of the non-objective all-unity, emphasizes the immediate danger of humankind's extermination:

Mankind lies groaning, half-crushed beneath the weight of its own progress. Men do not sufficiently realize that their future is in their own hands. Theirs is the task of determining first of all whether they want to go on living or not. Theirs the responsibility, then, for deciding if they want merely to live, or intend to make just the extra effort required for fulfilling, even on their refractory planet, the essential function of the universe, which is a machine for the making of gods. ${ }^{109}$ 
In a similar vein, Malevich criticizes the destructive tendencies of human beings that guide their actions and inevitably lead to conflicts (Malevich's belief in the evolution of humankind does not stop him from experiencing discontent with the present conditions of human existence):

Заполучив все различия, расположив их во времени, пространстве, общежитие вынужденно ждет катастрофы, базируясь на своем сознании, которое всегда катастрофично. Оно что-то осознает, а сознание его целиком предметно, поэтому и все в мире предметно и практично, и этого уже достаточно, чтобы жить в вечной тревоге, в ожидании катастрофы.

Having received all the differences, having located them in time and space, society [общежитие] is forcedly waiting for the catastrophe, relying on its own consciousness, which is always catastrophic. It is aware of something, and its consciousness is entirely objective, therefore everything in the world is objective and practical, and this is enough to live in eternal anxiety, in anticipation of a catastrophe. ${ }^{110}$

Malevich sees all the troubles of humankind rooted in objective perception of reality, which forbids him to imagine a society guided by love and understanding, something that Soloviev and Bergson are eager to portray in their writings. If Soloviev suggests that on the way towards allunity humankind will rejoin in brotherly love, a condition that is still objective as it does not demand a total dissipation of form, Malevich is convinced that the only path humanity must take is towards non-objectivity - total annihilation of things will lead towards the liberation in nothingness. Malevich states:

Действие Супрематизма не связано никакими границами “практических", “целеполезных”, “сообразных" “задач”, ни анализом, ни синтезом, никакими исканиями подлинного и не подлинного художественного эстетического, не служит ничему. Всё находится в беспредметном равенстве, или нуле веса, оно есть ничто как ответ на “что?” общежития. Тем более, что все человеческие усилия через все его целесообразности, все практические соображения идут к тому же беспредметному абсолютному сознанию, в котором оно потеряет всё из виду.

Супрематизм как беспредметность, как освобожденное ничто есть резкое противопоставление “организационной идейной предметности”.

The effect of Suprematism is not constrained by any boundaries of "practical", "purposeful", "conformable" "tasks," or analysis, or synthesis, by any search for genuine or non-genuine artistic aesthetic, it does not serve anything. Everything is in a state of non-objective equality, or zero of weight, it is nothing - the answer to "thing" of society [общежитие]. Moreover, all humanity's efforts through all the expediency, all practical considerations go to the same objectless absolute consciousness, in which it will lose sight of everything.

Suprematism as non-objectivity, as a liberated nothing, is in a sharp contrast with "organizational ideological objecthood". ${ }^{11}$ 
Even though Malevich's quest towards non-objectivity does not allow a stopover at the global village suggested by Soloviev, both thinkers are drawn towards the final destination of the liberated no-thingness. For Soloviev, all-unity is the Absolute "liberated" from all beings (according to the Latin word absolutum) that he calls God, Ein Sof (the Kabalistic notion translated as "non-something"), and "nothing."112 This definition of all-unity as the liberated nothing is in striking similarity with Malevich's understanding of Suprematism, pointing out an intellectual affiliation between the two thinkers.

Although Soloviev and Malevich propose the possibility for reaching the state of all-unity and non-objectivity of Suprematism, respectively, while Bergson proposes no comparable project (of leaping into the formless flux of duration without the possibility of return into the habitual objective reality), there are many parallels in the philosophical ideas of these thinkers, among which are the insistence on the use of intuition to access ultimate reality and understanding of reality as fundamentally aesthetic, elevating art to a practice capable of offering visions of reality as flux. 
${ }^{1}$ Vasily Vasilyevich Zenkovsky, A History of Russian philosophy, trans. G. L. Kline (London: Routlegde \& Paul, 1953), vol. 1, 170-171.

${ }^{2}$ Ibid., $73-75$.

3 James P. Scanlan, “A. F. Losev and mysticism in Russian philosophy,” Studies in East European Thought. 46, no. 4 (1994): 263.

${ }^{4}$ Michael Stoeber, "Mystical Concepts, Artistic Contexts," in Mystical Landscapes: From Vincent van Gogh to Emily Carr, 45-57 (Munich: DelMonico Books Prestel, 2017), 45.

${ }^{5}$ Ibid.

${ }^{6}$ As quoted in John Ferguson, An Illustrated Encyclopaedia of Mysticism and the Mystery Religions (London: Thames and Hudson, 1976), 126.

${ }^{7}$ Aldous Huxley, Ends and Means (London: Chatto \& Windus, 1946), 286.

${ }^{8}$ Denise Lardner Carmody and John Tully, Mysticism: Holiness East and West (New York: Oxford University Press, 1996), 6.

${ }^{9}$ William James, The Varieties of Religious Experience: A Study in Human Nature, Being the Gifford Lectures on Natural Religion Delivered at Edinburgh in 1901-1902, by William James (New York, London, Bombay, Calcutta, and Madras: Longmans, Green, And Co, 1917), 381.

${ }^{10}$ Denise Lardner Carmody and John Tully, Mysticism: Holiness East and West, 6-7.

${ }^{11}$ As quoted in Denise Lardner Carmody and John Tully, Mysticism: Holiness East and West, 7.

12 Robert K. C. Forman, Mysticism, Mind, Consciousness (New York: State University of New York Press, 1999).

${ }^{13}$ Kazimir Malevich, "Our Time is the Age of Analysis..." [1921], in Sobranie sochinenii v piati tomakh [Collected Works in Five Volumes] (Moscow: Gileia, 1995-2004), vol. 2, 30 (translation mine).

${ }^{14}$ Nel Grillaert, "Orthodoxy Regained: The Theological Subtext in Dostoevskijs 'Dream of a Ridiculous Man,"” Russian Literature 62, no. 2 (2007): 155.

${ }^{15}$ As quoted in John Ferguson, An Illustrated Encyclopaedia of Mysticism and the Mystery Religions, 45.

${ }^{16}$ Anonymous, The Upanishads (Penguin Classics) (London: Penguin Classics, 1965), 8.

${ }^{17}$ As quoted in Robert K. C. Forman, Mysticism, Mind, Consciousness, 5.

${ }^{18}$ Ibid., 5-6. 
${ }^{19}$ Ibid., 6.

${ }^{20}$ Kazimir Malevich, “The World as Non-Objectivity: Suprematism" [1927], in Sobranie sochinenii v piati tomakh [Collected Works in Five Volumes] (Moscow: Gileia, 1995-2004), vol. 2, 118-119 (translation mine).

${ }^{21}$ Bernard Mcginn, "Mystical Language in Meister Eckhart and His Disciples," Medieval Mystical Theology 21, no. 2 (2012): 221.

${ }^{22}$ Ibid., 220.

${ }^{23}$ Khardzhiev-Chaga Collection, Document H_0762, Stedelijk Museum Amsterdam.

${ }^{24}$ Kazimir Malevich, "The World as Non-Objectivity: Suprematism,” 105 (translation mine).

${ }^{25}$ Ibid., 109.

${ }^{26}$ Ibid., 106.

27 As quoted in Bernard Mcginn, "Mystical Language in Meister Eckhart and His Disciples," 221.

${ }^{28}$ Marion Ackermann and Isabelle Malz, Kandinsky, Malewitsch, Mondrian: Der weisse Abgrund Unendlichkeit = The Infinite White Abyss (Koln: Snoeck Verlagsgesellschaft mbH, 2014), 251.

${ }^{29}$ Kazimir Malevich, "Suprematism. From 'The Catalog of the Tenth State Exhibition. Nonobjective Creation and Suprematism," Sobranie sochinenii v piati tomakh [Collected Works in Five Volumes] (Moscow: Gileia, 1995-2004), vol.1, 150 (translation mine).

${ }^{30}$ Kazimir Malevich, "To the State Workers from Art" [1918], in Sobranie sochinenii v piati tomakh [Collected Works in Five Volumes] (Moscow: Gileia, 1995-2004), vol. 1, 84 (translation mine).

${ }^{31}$ Kazimir Malevich, "Suprematism. From 'The Catalog of the Tenth State Exhibition. Nonobjective Creation and Suprematism," 151 (translation mine).

${ }^{32}$ W. T. Stace, Mysticism and Philosophy (London: Macmillan \& Co, 1961), 86.

33 According to Webster's Encyclopedic Dictionary of the English Language (New York: Portland House, 1989) samādhi-n. Hinduism, Buddhism. Contemplation of an object of meditation, seen as one stage in which the distinction between subject and object is preserved, and another stage in which all distinctions are completely absorbed. [ $<$ Skt, a drawing together (of mind), deep contemplation] 
${ }^{34}$ Kazimir Malevich, "Laziness_-The Real Truth of Humankind" [1921], in Sobranie sochinenii $v$ piati tomakh [Collected Works in Five Volumes] (Moscow: Gileia, 1995-2004), vol. 5, 183 (translation mine).

${ }^{35}$ Kazimir Malevich, “The World as Non-Objectivity: Suprematism,” 106 (translation mine).

${ }^{36}$ As quoted in Paul J. Griffiths, "Pure Consciousness and Indian Buddhism," in The Problem of Pure Consciousness: Mysticism and Philosophy, ed. Robert K. C. Forman (New York, Oxford: Oxford University Press, 1990), 80-81.

${ }^{37}$ Ananda Kentish Coomaraswamy, The Dance of Šiva: Essays on Indian Art and Culture (New York, N.Y.: Dover, 1985), 103.

${ }^{38}$ L. M. Lopatin, “The Philosophy of Vladimir Soloviev," Mind: A Quarterly Review of Psychology and Philosophy XXV, no. 100 (October 1916): 456.

${ }^{39}$ As quoted in V. S. Soloviev, Divine Sophia: The Wisdom Writings of Vladimir Solovyov, ed. Judith Deutsch Kornblatt (Ithaca: Cornell University Press, 2009), 4.

40 Vladimir Soloviev, “The General Meaning of Art,” Library of Russian Religious, Philosophical, and Artistic Literature. Accessed September 19, 2017, 1 (translation mine). http://www.vehi.net/soloviev/smysl_isk.html.

${ }^{41}$ Oliver Smith, Vladimir Soloviev and the Spiritualization of Matter (Boston: Academic Studies Press, 2011), 32.

42 Hilary L. Fink, Bergson and Russian Modernism: 1900-1930 (Evanston: Northwestern University Press, 2012), 17.

${ }^{43}$ As quoted in Hilary L. Fink, Bergson and Russian Modernism: 1900-1930, 18.

${ }^{44}$ Kazimir Malevich, "Our Time is the Age of Analysis..." [1921], in Sobranie sochinenii v piati tomakh [Collected Works in Five Volumes] (Moscow: Gileia, 1995-2004), vol. 2, 30 (translation mine).

${ }^{45}$ Oliver Smith, Vladimir Soloviev and the Spiritualization of Matter, 26.

${ }^{46}$ As quoted in Charlotte Douglas, Swans of Other Worlds: Kazimir Malevich and the Origins of Abstraction in Russia (Ann Arbor, MI: UMI Research Press, 1980), 38.

${ }^{47}$ Charlotte Douglas, Swans of Other Worlds: Kazimir Malevich and the Origins of Abstraction in Russia, 50.

${ }^{48}$ As quoted in Charlotte Douglas, Swans of Other Worlds: Kazimir Malevich and the Origins of Abstraction in Russia, 52. 
${ }^{49}$ Kazimir Malevich, "On New Systems in Art" [1919], in Sobranie sochinenii v piati tomakh [Collected Works in Five Volumes] (Moscow: Gileia, 1995-2004), vol. 1, 172 (translation mine).

${ }^{50}$ Ibid.

${ }^{51}$ Vladimir Soloviev, Readings on Godmanhood (Moscow: Prospekt. Electronic, 2014), 125-126 (translation mine).

${ }^{52}$ As quoted in Vasily Vasilyevich Zenkovsky, A History of Russian philosophy, vol. 2, 511.

${ }^{53}$ Vasily Vasilyevich Zenkovsky, A History of Russian philosophy, vol. 2, 501.

${ }^{54}$ Ibid., 505.

${ }^{55}$ As quoted in Vasily Vasilyevich Zenkovsky, A History of Russian philosophy, vol. 2, 498.

${ }^{56}$ As quoted in Vasily Vasilyevich Zenkovsky, A History of Russian philosophy, vol. 2, 499.

${ }^{57}$ Vladimir Soloviev, "The General Meaning of Art," 3 (translation mine).

http://www.vehi.net/soloviev/smysl_isk.html.

${ }^{58}$ Kazimir Malevich, "A Note on the Limits of Reality" [sometime between 1919-1922], in Sobranie sochinenii v piati tomakh [Collected Works in Five Volumes] (Moscow: Gileia, 19952004), vol. 5, 194 (translation mine).

${ }^{59}$ Kazimir Malevich, "From Cubism and Futurism to Suprematism" [1915], in Sobranie sochinenii v piati tomakh [Collected Works in Five Volumes] (Moscow: Gileia, 1995-2004), vol. 1, 40 (translation mine).

${ }^{60}$ Kazimir Malevich, "To the State Workers from Art" [1918], in Sobranie sochinenii v piati tomakh [Collected Works in Five Volumes] (Moscow: Gileia, 1995-2004), vol. 1, 87 (translation mine).

${ }^{61}$ Khardzhiev-Chaga Collection, Document H_0758, Stedelijk Museum Amsterdam.

${ }^{62}$ Vladimir Soloviev, "The General Meaning of Art," 5-6 (translation mine). http://www.vehi.net/soloviev/smysl_isk.html.

${ }^{63}$ Vladimir Soloviev, Readings on Godmanhood, 98 (translation mine).

${ }^{64}$ Vladimir Soloviev, "The General Meaning of Art," 3 (translation mine). http://www.vehi.net/soloviev/smysl_isk.html.

${ }^{65}$ Kazimir Malevich, "On New Systems in Art" [1919], in Sobranie sochinenii v piati tomakh [Collected Works in Five Volumes] (Moscow: Gileia, 1995-2004), vol.1, 157 (translation mine). 
${ }^{66}$ Vladimir Soloviev, "The General Meaning of Art," 3 (translation mine).

http://www.vehi.net/soloviev/smysl_isk.html.

${ }^{67}$ Ibid., 4.

${ }^{68}$ Kazimir Malevich, "Suprematism as Non-Objectivity" [1922], in Sobranie sochinenii v piati tomakh [Collected Works in Five Volumes] (Moscow: Gileia, 1995-2004, vol. 3, 248-249

(translation mine).

${ }^{69}$ Hilary L. Fink, Bergson and Russian Modernism: 1900-1930, xiii.

${ }^{70}$ Ibid., XV.

${ }^{71}$ Henri Bergson, The Creative Mind, trans. Mabelle L. Anderson (Westport, Conn.: Greenwood Press, 1946), 188-189.

${ }^{72}$ Ibid., 200.

${ }^{73}$ Henri Bergson, Creative Evolution, trans. Arthur Mitchel (Mineola, NY: Dover Publications, 1998), 45.

${ }^{74}$ Henri Bergson, The Creative Mind, 200-202.

${ }^{75}$ Ibid., 127.

${ }^{76}$ Kazimir Malevich, "Form, Colour, and Sensation" [1928], in Sobranie sochinenii v piati tomakh [Collected Works in Five Volumes] (Moscow: Gileia, 1995-2004), vol.1, 313 (translation mine).

${ }^{77}$ Ibid., 314.

${ }^{78}$ Ibid., 315.

${ }^{79}$ S. A. Kuznetsov, Bolshoi tolkovyi slovar russkogo iazyka (Sankt-Peterburg: Norint, 2000), 1097.

${ }^{80}$ Henri Bergson, The Creative Mind, 191.

${ }^{81}$ Ibid., 190.

${ }^{82}$ Ibid., 212.

${ }^{83}$ Kazimir Malevich, "Suprematism as Pure Knowledge" [1922], in Sobranie sochinenii v piati tomakh [Collected Works in Five Volumes] (Moscow: Gileia, 1995-2004), vol. 3, 79 (translation mine).

${ }^{84}$ Henri Bergson, The Creative Mind, 212. 
${ }^{85}$ Kazimir Malevich, "Futurism, Kinetic and Dynamic" [1929], in Sobranie sochinenii v piati tomakh [Collected Works in Five Volumes] (Moscow: Gileia, 1995-2004), vol. 2, 226 (translation mine).

${ }^{86}$ Kazimir Malevich, "Suprematism as Pure Knowledge," 85 (translation mine).

${ }^{87}$ Henri Bergson, Creative Evolution, 11.

${ }^{88}$ Ruth Lorand, “Bergson's Concept of Art," British Journal of Aesthetics 39, no. 4 (October 1999): 400.

${ }^{89}$ Henri Bergson, Creative Evolution, 176-177.

${ }^{90}$ As quoted in Hilary L. Fink, Bergson and Russian Modernism: 1900-1930, 18-19.

${ }^{91}$ Ruth Lorand, "Bergson's Concept of Art," 403.

92 Henri Bergson, Creative Evolution, 6-7.

${ }^{93}$ Ibid., 4.

${ }^{94}$ Ibid., 5-7.

95 Ibid., 45.

${ }^{96}$ Kazimir Malevich, "Suprematism as Pure Knowledge,” 73 (translation mine).

${ }^{97}$ Ibid., 208.

${ }^{98}$ Henri Bergson, The Two Sources of Morality and Religion (Westport, Conn.: Greenwood Press, 1974), 255.

${ }^{99}$ Ibid., 256.

${ }^{100}$ Kazimir Malevich, “Suprematism as Pure Knowledge,” 108 (translation mine).

${ }^{101}$ Kazimir Malevich, "God Is Not Cast Down. Art, Church, Factory” [1920], in Sobranie sochinenii v piati tomakh [Collected Works in Five Volumes] (Moscow: Gileia, 1995-2004), vol. 1, 253 (translation mine).

102 Ibid.

${ }^{103}$ Ibid., 248.

${ }^{104}$ Kazimir Malevich, "Suprematism as Pure Knowledge,” 104 (translation mine). 
${ }^{105}$ Henri Bergson, The Two Sources of Morality and Religion, 256.

${ }^{106}$ Ibid., 201.

${ }^{107}$ Ibid.

${ }^{108}$ Ibid.

${ }^{109}$ Ibid., 275.

${ }^{110}$ Kazimir Malevich, "Suprematism as Pure Knowledge," 97 (translation mine).

${ }^{111}$ Ibid., 107.

112 Teresa Obolevitch, "All-Unity According to V. Soloviev and S. Frank. A Comparative Analysis," Forum Philosophicum 15, no. 2 (2010): 414. 


\section{Chapter 2: Malevich and the Fourth Dimension}

\section{Introduction:}

The chapter commences with a brief introduction of the history of the concept of the fourth dimension outside of Russia by looking at the work of Hermann Grassmann, Bernhard Riemann, and Washington Irving Stringham, among others. This short introduction is followed by an outline of the concept's popularity among professional mathematicians and lay public in Russia. Some alternative to scientific interpretations of the fourth dimension are considered through consulting such counter-sciences as spiritualism and Theosophy. Malevich is unambiguous about his interest in the concept of the fourth dimension: the artist includes the phrase in the titles of his paintings and mentions it in his writings. Pyotr Ouspensky's definition of the concept, one of the core ideas in his writings, relies on the interrelationship of time and space. Malevich's art, which is at once static and dynamic - the dynamism of Suprematist forms is expressed via the static media of painting and sculpture — demands a further inquiry into the artist's view of his art's temporality. This chapter approaches this inquiry through outlining the artist's concern for the geometry of higher dimensions and tracing the presence of spiritualist, theosophist, and Ouspensky's ideas in Malevich's worldview. The chapter concludes with a more in-depth study of the points of intersections between Ouspensky's esoteric teachings on the fourth dimension and Malevich's Suprematism.

The Fourth Dimension Outside of Russia:

Mathematical pondering upon the idea of a four-dimensional space (4D space) as a separate category of mathematics has not been initiated until roughly around the middle of nineteenth century. Among some of the most prominent works in this area of inquiry were Arthur Cayley's 1843 article "Chapters in the Analytical Geometry of (n) Dimensions" and Hermann 
Grassmann's Die lineale Ausdehnungslehre, ein neuer Zweig der Mathematik (The Theory of Linear Extension, a New Branch of Mathematics) of $1844 .{ }^{1}$ British mathematician, Arthur Cayley, coined the terminology of $n$-dimensional geometry in the aforementioned text, which, besides offering algebraic equations with $n$ variables is, curiously, also Cayley's memoir. The term "geometry of $n$ dimensions" appears only in the title and mathematical ideas offered do not approach visualization of four-dimensional space. ${ }^{2}$ Hermann Grassmann's mathematics, even though not yet concerned with visual properties of multi-dimensional spaces, points in the direction of this inquiry.

The grammar schoolteacher Grassmann's work received little attention at the time of its publication, partly due to the philosophical tone of his writings and the lack of formulae in the text. However, nowadays, Grassmann is considered the real founder of $n$-dimensional space and the father of algebraic ideas that were so visionary that came to blossom only in the twentieth century. ${ }^{3}$ The central idea of Grassman's theory of linear extension has to do with formation of higher-dimensional extensive quantities by means of product formation of vectors. For example, a parallelogram (Grassmann's “second-level figure") is formed by two vectors, and a parallelepiped ("third-level figure") by three. ${ }^{4}$ This understanding of how higher-dimensional geometric objects are spawned from lower dimensional ones becomes one of the most accessible ideas to explain the possibility of the fourth dimension and can be regarded as partially responsible for the popularity of the concept among the lay public of the fin-de-siècle. Grassmann infers: "since this method of formation is theoretically applicable without restriction, I can define systems of arbitrarily high level by this method...geometry goes no further [than third-level figures], but abstract science knows no limit." ${ }^{.5}$ For Malevich it is the abstract art of 
Suprematist higher planes that is "the freest mass structure of excitation, which knows no limits." 6

Another important event in the history of formation of the geometry of higher dimensions is Bernhard Riemann's 1854 lecture “Über die Hypothesen, welche der Geometrie zu Grunde liegen" (On the Hypothesis which lie at the Bases of Geometry). ${ }^{7}$ In this lecture, Riemann introduces his concept of manifold, which radically changed the conceptualization of space and allowed Einstein to develop his theory of general relativity. ${ }^{8}$ Riemann's manifold is a folded space that exists outside of the Euclidian space and can have infinite number of dimensions. In Riemannian geometry, instead of being defined as a conglomerate of points each given space is defined as being composed of other spaces (that can be locally treated as Euclidian) and the relationship among them. Riemann's analysis is concerned with continuous manifolds and space as continuous phenomena-the line of thinking that is parallel to that of Bergson's philosophy of duration. ${ }^{9}$ It is possible to think of Malevich's Suprematist paintings as expressive of Riemannian geometry. The artist not only treats the spaces he creates as continuous—dynamic Suprematist sensations cannot be granular-but he also emphasizes that the Suprematist art's intrinsic motivation is to create a unified painterly body that consists of a "variety of lines, volume, plane, colour"10 — spaces of n-dimensions through which this painterly body is defined (note that to the list of spatial elements of one-dimensional line, two-dimensional plane, and three-dimensional volume, Malevich adds colour, tempting to interpret it as a four-dimensional configuration).

It is quite possible that the idea of the folded space introduced by Riemann allowed Irvin Stringham to develop a method to draw four-dimensional shapes- something that has not been done prior to Stringham's draftsman's work in his 1880 paper titled "Regular Figures in $n$ - 
Dimensional Space.” Stringham's approach to visualizing four-dimensional figures involves determining the number and shapes of three-dimensional cells, or coverings, that a fourdimensional figure consists of, and imagining these cells folded up to form a 4D figure. ${ }^{11}$ This way of treating four-dimensional solids (hypersolids) on the basis of analogy, such as that between the relationship of a point and a line, a line and a square, and a square and a hypercube (4D cube), was a common strategy of dealing with the unimaginable fourth dimension at the end of the nineteenth and early twentieth centuries - an approach that seems to have been borrowed from Grassmann's linear vector extensions. This visualization tactic was so practical that allowed German mathematician, Victor Schlegel, to create three-dimensional models of polyhedroids' projections, which are geometric projections of four-dimensional figures whose cells (a three-dimensional analogue of a two-dimensional face, such as a triangle of a tetrahedron) are polyhedrons, or solids with flat polygonal faces. ${ }^{12}$ Schlegel's illustrations of these models have been known to inspire Cubist painters, among whom were the scientifically minded Jean Metzinger and Juan Gris, tutored in the new geometries by Maurice Princet, an insurance actuary with an in-depth knowledge of mathematics. ${ }^{13}$

The Fourth Dimension in Russia:

Even though theories of the fourth dimension of space have been widely discussed among physicists and mathematicians at international forums, and the field of four-dimensional geometry has become a fully developed mathematical discipline towards the end of the nineteenth century, it appears that mathematicians in Russia at the time did not express any particular interest in $n$-dimensional geometry.

In Kazan University, mathematicians continued the work of Nikolai Lobachevsky, who, in 1830, independently from János Bolyai who published his findings in 1832, has developed a 
non-Euclidian geometry often referred to as hyperbolic. The latter type of geometry supports the notion that if given a line and a point not on this line, infinitely many lines parallel to the given line can be drawn through that point. Interestingly, non-Euclidian geometries, widely explored by Russian mathematicians, would only gain in popularity among the Russian artists after the revolution of 1917, while French artists began dabbling in their enigmas at least a decade earlier. ${ }^{14}$

In Petersburg School of Mathematics, number theory, mathematical physics, and theory of probability were among the fields of mathematics that were strong; higher-dimensional geometry was not. ${ }^{15}$ Moscow School of Mathematics was famous for its developments in set theory and theory of functions. ${ }^{16}$ Lack of concern for the four-dimensional geometry among professional mathematicians appears to also be reflected in a comparable disregard for $n$ dimensional geometry among the amateur science enthusiasts. The end of the nineteenth and early twentieth century in Russia has witnessed an unprecedented economic growth, which created demand for scientific knowledge and instigated a utopian belief in the possibilities of science. This enthusiasm was reflected in the abundance of periodicals devoted to a variety of scientific fields, among which was "Вестник опытной физики и элементарной математики” (Bulletin of Experimental Physics and Elementary Mathematics, published from 1886-1917). Curiously, this journal, at the time one of the most popular scientific magazines that had articles on elementary mathematics, abstract algebra, non-Euclidian geometry, theory of functions, and philosophy of mathematics, did not contain any articles on $n$-dimensional geometry throughout its almost thirty-year publication span. ${ }^{17}$ 
Spiritualism and the Fourth Dimension:

It is quite possible that the lack of concern for the topic of $n$-dimensions of space within the government-funded educational institutions and mainstream mathematical forums, such as the aforementioned journal, was related to the popularity of the fourth dimension among the followers of the counter-sciences, to which many members of the scientific professions simultaneously belonged. The probability of this suggestion is reinforced if one takes into consideration that the concept of the fourth dimension was introduced to the Russian public through the writings of German astrophysicist and psychic investigator Johann Karl Friedrich Zöllner, who "proved" the existence of the fourth dimension in his spiritualistic experiments, which involved confirming the validity of Zöllner's hypothesis that spirits reside in the fourth dimension. ${ }^{18}$ Zöllner conducted his experiments with an American medium Henry Slade, who, allegedly was able to tie four knots on a string that was originally unknotted without any observable interference with the string. The possibility of such a fit is explained with the assistance of an analogy: a three-dimensional being can straighten a cord bent in two dimensions without touching the ends of a string, by simply lifting the cord in the third dimension; similarly, a four-dimensional being can tie a knot in three-dimensions without touching the ends of a string, by lifting the cord in the fourth dimension. ${ }^{19}$

Alexander Butlerov, an outstanding Russian chemist interested in spiritualism, published his thoughts on the possibility of explaining mediumistic phenomena using the theories of the fourth dimension in his article "Четвертое Измерение Пространства и Медиумизм” (Тhe Fourth Dimension of Space and Mediumism, published in Russkij Vestnik, February 1878), where he quoted Zöllner at length. Three years prior to this publication, Butlerov published an article in "Русский Вестник" (Russian Bulletin), titled "Mediumistic Phenomena" (published 
November, 1875). Editor of this important literary and socio-political journal provided an endnote to the title of Butlerov's essay, which stated: "The name of the author of this article, A.M. Butlerov, a professor of chemistry at the St. Petersburg University who enjoys such an honorable reputation and authority in the academic world, involuntarily draws special attention to it and in any case justifies its appearance in the magazine." ${ }^{20}$ [“Имя автора этой статьи, пользующегося столь почетной известностью и авторитетом в ученом мире, профессора химии при С.-Петербургском университете, А.М. Бутлерова, невольно обращает на нее особое внимание и во всяком случае оправдывает ее появление в журнале]." Butlerov, as if in response to this endnote, expresses his unwillingness to publish materials on spiritualism in his homeland:

While more than on one occasion I printed about my observations on mediumistic phenomena in German, I considered it still untimely to speak about them in the Russian press. That sharp prejudice with which the majority was and is regarding this question, that, one might say, disgust with which almost all the editorial offices of newspapers and magazines were reluctant to give it a place on the pages of their publications, all this did not call for my exposition of my observations in our organs of glasnost. ${ }^{21}$

Печатая не раз по-немецки о моих наблюдениях над явлениями медиумизма, я считал до сих пор несвоевременным говорить о них в русской печати. То резкое предубеждение, с которым относилось и относится к этому вопросу большинство, то, можно сказать, отвращение, с которым почти все редакции газет и журналов изредка и нехотя решались давать ему место на страницах своих изданий, все это не призывало меня к изложению моих наблюдений в наших органах гласности.

The skepticism towards spiritualism described by Butlerov did not stop it from becoming one of the most popular forms of counter-science at the turn of the century. Its two forms - mystical that resembled an alternative religion and scientific, which was guided by a positivist rationaleattracted most individuals. In the beginning of the twentieth century, there was an estimated 1,672 official and unofficial spiritualist circles, existing in Moscow and St. Petersburg. ${ }^{22}$ Spiritualism appealed mainly to those who were inspired by the French Decadents. Thus, the Symbolist poets Aleksandr Blok and Valeryi Bryusov frequented séances, while the latter also 
contributed to the Spiritualists' own Journal Rebus (1881-1917) [where Butlerov often published as well] and intended to write a novel with the self-incriminating title, The Medium. Andrei Bely, a younger Symbolist, has incorporated a mediumistic character into his novel The Silver Dove. ${ }^{23}$

During the first decade of the twentieth century, Kazimir Malevich experimented with Symbolism, which became associated with spiritualism, and was deeply "interested in the metaphysical concerns of the Blue Rose group of Symbolist painters led by Pavel Kuznetsov."24 In Malevich's works of that period one can certainly witness the effects of the artist's infatuation with Symbolism. It is less obvious however, whether Malevich was interested in spiritualism and the mediumistic interpretation of the fourth dimension at the time. Towards the end of the first decade of the twentieth century, Malevich's short-lived enthusiasm for Symbolism was outlived by his new inspiration sparked by his visit to "The Golden Fleece" exhibition of 1908 that presented the works of Vincent Van Gogh, Paul Cézanne, and Henri Matisse, among others. ${ }^{25}$ Shortly after, Malevich took an anti-Symbolist stance. It is quite possible that together with his having denounced Symbolism, Malevich rejected all the cultural practices associated with it, which must have included spiritualism and the mediumistic interpretation of the fourth dimension as a harbor for disembodied souls.

Theosophy and the Fourth Dimension:

Another occult tradition that offered its interpretation of the mathematical theories of the fourth dimension is Theosophy. Founded by a Russian émigré Elena Blavatsky, in 1875, in New York, it quickly gained popularity in Russia, offering a doctrine that combined a variety of ancient belief systems into an eclectic brew that announced itself as scientific religion, a convenient for many merging between science and religion. Among the supporters of Theosophy in Russia were Andrei Bely, Pyotr Ouspensky, Nikolai Berdyaev, and Wassily Kandinsky ${ }^{26}$ Mme Blavatsky, 
according to her disciple Charles Leadbeater, did not speak of the same idea of the geometrical fourth dimension when she mentioned that the fourth dimension is an "absurdity" and just but "another way to describe the interpenetration of matter." Instead of Blavatsky, who, as it seems, was not particularly fond of mathematical reasoning, it was Leadbeater who introduced the theosophical explanation of the fourth dimension of space. Leadbeater, inspired by the writings of Charles Hinton, was convinced that Hinton, without being consciously aware, was studying the astral plane, defined by Annie Besant, a fellow Theosophist, as a "definite region of the universe, surrounding and interpenetrating the physical, but imperceptible to our ordinary observation because it is composed of a different order of matter." ${ }^{27}$ In Leadbeater's cosmology, the fourth dimension was identical to the astral plane. Leadbeater writes: "Hinton is not a member of the Theosophical Society, and I think he has no idea that through the study of the higher spaces he approaches the sensing of the astral plane. However, that is the case, and astral plane corresponds with the four-dimensional space."28

Charles Hinton, a British mathematician and writer of science fiction works, became interested in the fourth dimension around 1880, with his first publication on the topic titled "What is the Fourth Dimension?" (1880). Hinton promoted intuitive and visual understanding of the concept, an educational project which prompted him to create a variety of colour illustrations of the tesseract (the term for hypercube that Hinton is credited with coining), a printed collection of which could be purchased when his later book "The Fourth Dimension" was published in 1904. Hinton's philosophy is centered on the belief that the evolution of humankind is possible through the evolution of the ability to visualize the fourth dimension. Russian mathematician and esotericist, Pyotr Ouspensky, would pick up Hinton's evolutionary optimism and turn it into a full-blown Promethean hyperspace philosophy. (In its underlying belief in the possibility of 
completely transforming the world, Prometheanism, so characteristic of the Russian culture of the turn of the centuries, united both, Ouspensky and Malevich. $)^{29}$ To a contemporary reader, Hinton's writings do not sound as fantastical as do Leadbeater's, which further develop Hinton's more sober approach to hyperspace philosophy to accommodate the Theosophical worldview. However, Hinton's works on the fourth dimension lend themselves well to occult interpretations. When reading "What is the Fourth Dimension?" one doesn't need to flex imagination to reach Leadbeater's conclusion that Hinton's fourth dimension is the Theosophical astral plane: "So if there were four-dimensional objects, we should only know as solids - the solids, namely, in which they intersect our space. Why, then, should not the four-dimensional beings be ourselves, and our successive states the passing of them through the three-dimensional space to which our consciousness is confined?" 30

Using Hinton's strategy to explain the concept of the fourth dimension of space by way of analogy between two-dimensional beings' perception of a three-dimensional space and threedimensional beings' perception of a four-dimensional space, Leadbeater explains why the fourth dimension of space is not immediately available to human senses. This thought experiment leads Leadbeater to a much more daring proposition than the mathematicians of the time could openly afford: three-dimensional beings exist beyond the boundaries of Euclidian space, a feat achieved by an extension of their souls into the higher dimensions. Leadbeater writes:

Now you understand that although we are seemingly surrounded by only three-dimensional objects, all those objects, or some, have, if, there is a four-dimensional space, four dimensions, while we only see what our limitations permit us. So, for example, all our fellow creatures may be four-dimensional beings. ... You might be, here on this plane, only a very common person, but one who could see in the fourth dimension the unknown part, that which we call "soul," might see a much higher development. ${ }^{31}$

The proposition that human soul resides in the fourth dimension of space coincides with the teachings of Theosophy that the density of matter changes the further away one is from the physical reality made up of the densest matter in the universe. Soul, having a lesser density than 
that of a human body, exists in the astral plane, which Leadbeater believes to have been synonymous with the mathematical concept of the fourth dimension. Buttressing his ideas on Hinton's example of the differences in spatial extensions of water and its gaseous form, Leadbeater discusses the relationship between the density of matter and this matter's possible existence in higher dimensions of space: "You know that a liquid, thrown on a flat surface, spreads in two directions, whilst a free gas spreads out in three dimensions. When you let your liquid, from a space of three dimensions, spread itself in two dimensions, it must become smaller in the direction of the third dimension. Is it, then, not possible that your gas can spread in three dimensions because it has been poured out of a fourth?"32 Dispersion of density and relief from weight that necessarily follows could be the required steps towards existence in the higher dimensions of space. Thus, the concepts of weight and the lack thereof are fundamentally important for Theosophy.

Curiously, the concept of weightlessness was one of the central themes in Kazimir Malevich's writings. Malevich interprets the concept of weight not only as a physical characteristic of a body, its heaviness, but also as the weight exerted on a mind by the burden of existence. Malevich advocates for overcoming these forces of gravity, whether they are real or ideal. Technological progress assists humankind with creating conditions, which make one's physical body appear utterly light — one can truly feel weightless when accelerating in a speedy automobile, or lose the sensation of their body's heaviness in a space rocket, floating due to an almost complete lack of gravity. Taking into account Malevich's interest in space exploration, this radical way of achieving weightlessness was something he probably pondered upon. There are also ways to achieve the lightness of mind and lift one's psyche to higher realms. For Malevich, lightness is harmony: 
Вес и тяжесть идут к атрофии.

Weight and gravity steer towards atrophy. ${ }^{33}$

Гармония это то, что не имеет веса, а следовательно, силы давления, падения и поднятия. В ней нужно видеть искомое художественное начало как статизированный момент. ... Безвесие и есть тот искомый предел всякого строительства. Материя невесома, как невесомы все явления в нашем сонном состоянии мозга, но они нас давят до боли, до кошмара. Во сне, наяву мы стараемся тоже обратить все явления в безвесие, уничтожая их последним. ... Итак, с этой точки зрения вся прогрессия человека заключается в том, чтобы найти такую систему, по которой вес материалов превратится в полное безвесие (гармония безвесия.) ... Вся наша техническая прогрессия совершенна тем, что каждый шаг движения старается сделать легким, благодаря чему движутся пароходы, поезда, и мы себя со скоростью и легкостью бросаем через большие пространства (психодвижение).

Harmony is something that has no weight, and therefore, no forces of pressure, fall, and rise. In it one must see the desired artistic principle as a moment of stasis. ... Weightlessness is that desired limit of all construction. Matter is weightless, as are weightless all the phenomena in our sleepy state of the brain, but they pressure us to pain, to nightmare. In a dream, in real life, we also try to turn all the phenomena into weightlessness, destroying them last. ... So, from this point of view, the whole progression of humankind is concerned with finding such a system, according to which the weight of materials will turn into complete weightlessness (harmony of impassivity.) ... All our technical progression is perfect because it attempts to make light every step of movement, in virtue of which steamers and trains are moving, and we throw ourselves with speed and lightness through vast spaces (psychomovement). ${ }^{34}$

Malevich's weightless "psychomovement," the movement of the human psyche, through "the vast spaces," brings to mind the Theosophical conviction that it is the lighter body of a human being, the astral body that is capable of traveling through the astral plane. Even though Malevich doesn't indicate that his "vast spaces" are anything akin to the astral plane, his insistence on lightness as a quality required for psychic explorations is similar to that found in Theosophy. It is difficult to be certain whether Malevich was consciously interweaving Theosophical ideas with his own, but the notion of a human mind, outside of a body, being a cosmic nomad exploring space betrays if not an affiliation, then at least familiarity with some of the concepts of this popular occult doctrine. 


\section{Pyotr Ouspensky and the Fourth Dimension:}

Although, there are some common threads in Malevich's writings and the interpretations of the concept of the fourth dimension explicated in spiritualism and Theosophy, neither one nor the other system of thought inspired Malevich as much as did the ideas on higher dimensions of Pyotr Ouspensky. A true successor to Charles Hinton, Ouspensky was introduced to the concept of the fourth dimension early on, by his father, who devoted much time to this puzzling study. ${ }^{35}$ Ouspensky had a well-rounded education and was trained not only in the mathematics and the sciences but also in the arts. Disenchanted by the positivist leanings of contemporary to his time thinkers, Ouspensky wrote in a way that truly synthesized science, philosophy, and esotericism - a tendency to which his writings, such as his most important works The Fourth Dimension (1909) and Tertium Organum (1911), can surely attest. The extent of the grandeur of Ouspensky's intentions is disclosed by the title of his most influential work, Tertium Organum (Latin for "The Third Canon"). The meaning of the title is related to Aristotle's Organon (Latin for instrument, tool, logic), a standard collection of Aristotle's six works on logic, and Francis Bacon's Novum Organum (Latin for “The New Organon”), Bacon's attack on the Aristotle's logic system. By naming his treatise "The Third Canon," Ouspensky claims that his work is a founding text explicating the canons of the new logic system, as, in their own time, claimed the authors of the other two texts just mentioned. The truths contained in Ouspensky's volume, however, are arcane, expelled by the Aristotelian tradition of empiricism that found expression in a much despised by Ouspensky positivism: "I have called this system of higher logic Tertium Organum because for us it is the third canon — third instrument—of thought after those of Aristotle and Bacon. The first was Organon, the second, Novum Organum. But the third existed earlier than the first." ${ }^{36}$ Claude Bragdon, who wrote the introduction to the English edition of 
Tertium Organum (that without the knowledge of Ouspensky was published in New York, in 1922), states: "Ouspensky presents a new logic, or rather, he presents anew an ancient logic - the logic of intuition — removing at a stroke all of the nightmare aspects, the preposterous paradoxes of the new mathematics, which by reason of its extraordinary development has shattered the old logic, as a growing oak shatters the containing jar. ${ }^{.37}$ In these tumultuous times when mathematics ceased to be the unshakable pillar of certainty, Ouspensky's renewed logic of intuition aimed at positivist apathy and skepticism was to revive mathematics through recharging its forgotten dialogue with philosophy. Since, it would have been impossible to create a philosophy of (hyper)space without addressing Kant's propositions on the matter, Ouspensky began this dialogue with Kant's Critique of Pure Reason.

In terms of Kantian ideas on space, Ouspensky agrees with Hinton, who noted that Kantian proposition that we cognize things through the senses, relying on our perception of space and time alone, is usually regarded negatively, as a barrier that blocks us from knowing things as they really are, things in themselves. ${ }^{38}$ After Hinton, Ouspensky proposes a radically different interpretation of Kant, which states that by studying space, the reality, in fact, can be known. Ouspensky quotes from Hinton's New Era of Thought: "The first postulate of this book is a full recognition of the fact that it is by means of space that we apprehend what is. Space is the instrument of the mind. ... It is important to develop the space sense, for it is the means by which we think about real things." ${ }^{39}$ Ouspensky further develops the thought began by Hinton and suggests that what is needed is an alteration in perception, or, more specifically, evolution of space-sense, leading to the knowledge of the noumenal reality: "Kant established the fact that the development of knowledge under the existing conditions of receptivity will not bring us any closer to things in themselves. But there are theories asserting that it is possible, if desired, to 
change the very conditions of receptivity, and thus to approach the true substance of things." 40 In Ouspensky's project of changing "the very conditions of receptivity," one can recognize Malevich's conviction that it was the artist's role to attune the perception apparatus of the viewer in order to enable the perceptual shift necessary for sensing the harmony of the new realism of Suprematism. ${ }^{41}$

A proposition that Ouspensky was an extremely important thinker for Malevich can be supported by the historical findings of John E. Bowlt, who, in his essay "Esoteric Culture and Russian Society," discusses a fruitful cultural atmosphere that formed in a Saint Petersburg's bohemian cabaret the Stray Dog, which both Malevich and Ouspensky frequented between December 1911 and 1914. The latter enjoyed conversing with the audience of the cabaret on the topics of "the Tarot, theosophy, Alexandrian Christianity, the French magical revival, Russian orthodoxy, neo-Platonism, Jakob Böhme, the monks of Athos [the latter topic I will discuss in the chapter on Malevich and infinity]." ${ }^{42}$ Bowlt suggests that the Stray Dog was also the venue where Ouspensky shared the ideas from his recently published Tertium Organum. This would explain the fact that Malevich's notebooks contain an almost verbatim quotation belonging to the former-highly unusual evidence if one takes into account that Malevich almost never quoted any thinkers and even claimed that he disdained reading. The quote states the following: "The forms of our consciousness, their modes of expression, continuously evolve and, apart from the forms known to us, new ones will be formed." 43 Even though Malevich did not reference the author of these lines, one can find the paragraph that they were extracted from in Tertium Organum's chapter VIII, devoted to Ouspensky's theory of the relationship between the evolution of psychic apparatus and perception of higher dimensions, among other things. There, Ouspensky states: 
Мы еще не вполне ясно отдаем себе отчет, в какие формы выльется развитие человеческих способностей. Но мы уже можем сказать, что формы сознания и способы выражения их непрерывно эволюционируют и кроме известных нам форм должны образовывать новые.

В настоящий момент у нас есть три единицы психической жизни - ощущение, представление, понятие (и идея), и начинает образовываться четвертая единица - высшая интуиция.

... Если бы мы могли изменить свой психический аппарат и увидели бы при этом, что изменился мир кругом нас, то это было бы для нас доказательством зависимости свойств пространства от свойств нашего сознания.

Например, если бы мы могли к трем существующим у нас единицам психической жизни прибавить четвертую, то есть сделать высшую интуицию, существующую сейчас только в зачаточном виде, такой же определенной, точной и действующей согласно нашей воле, как понятие, - и если бы при этом увеличилось число характеристик пространства, то есть если бы пространство из трехмерного стало четырехмерным, - то это подтвердило бы наше предположение и доказало бы идею Канта, что пространство с его свойствами является формой нашего чувственного восприятия.

We are not yet fully aware of the forms in which the development of human abilities will result. But we can already say that the forms of our consciousness, their modes of expression, continuously evolve and, apart from the forms known to us, new ones will be formed. ${ }^{1}$

At the moment, we have three units of psychic life - sensation, representation, concept (and idea), and the fourth unit - the higher intuition - begins to form.

... If we could change our psychic apparatus and see at the same time that the world around us has changed, this would be for us the proof of the dependence of the properties of space on the properties of our consciousness.

For example, if we could add a fourth to the three existing units of psychic life, that is, to make a higher intuition that exists now only in an embryonic form, as certain, precise and acting according to our will as concept - and if in doing so the number of characteristics of space increases, that is, if the space from the three-dimensional becomes four-dimensional, then this would confirm our assumption and prove Kant's idea that the space with its properties is the form of our sensory perception. ${ }^{44}$

According to Ouspensky, the properties of space are dependent on the properties of

consciousness, leading him to a proposition that for a creature, which possesses sensations only, the world is a one-dimensional line, while for a human being, who possesses sensations, perceptions, and conceptions, the world reveals itself as a three-dimensional Euclidian space. ${ }^{45}$ Developing the fourth psychic ability of higher intuition, which Ouspensky, after Hinton, terms "space-sense" even though the meaning of the term is altered, brings knowledge of the world's true nature, in all its four dimensions.

\footnotetext{
${ }^{1}$ In English edition of Tertium Organum the part quoted by Malevich is omitted.
} 
Ouspensky provides a detailed description of the fourth and the final stage of psychic evolution. Upon entering this stage of development, human beings gain the ability to perceive the fourth dimension of space, conceive of the past and the future as the present, sense infinity as the only actually existing reality, operate with such types of knowledge as mathematics of the infinite, intuitive art and mystical religion. This stage of evolution is the cradle of new beings, the super-beings. Moreover, this race, according to Ouspensky, already exists and “люди новой расы уже начинают узнавать друг друга. Уже устанавливаются лозунги и пароли...” "people of the new race are already beginning to recognize each other. Slogans and passwords are being established ${ }^{2} \ldots . "{ }^{\prime 6}$ Taking into account that Ouspensky considers art to be the language of the future-in a new world full of new experiences for which no concepts yet exist, art is an invaluable tool for communication - it is tempting to assume that Malevich regarded himself if not a representative of the new race of super-beings then at least as someone approaching their psychic excellence. Indeed, Malevich's Suprematism, with its concern for the study of the infinite through intuitive insights, can truly be considered a new type of knowledge system prepared to lead humanity to the last stage of psychic evolution prophesied by Ouspensky.

Where Ouspensky truly extends Hinton's ideas on the fourth dimension is in the conception of the relationship between time and space. Ouspensky understands time as an illusion created by the passing of the four-dimensional world through three-dimensional reality, proposing that the physical three-dimensional space is a section of a noumenal four-dimensional space. ${ }^{47}$ Unable to see time as infinite spatial extension human beings observe it as if through a narrow slit, perceiving what is called the present, while falsely agreeing on the non-existence of

\footnotetext{
${ }^{2}$ This part is also omitted from the English edition of Tertium Organum.
} 
the past and the future. ${ }^{48}$ If one's consciousness is able to overcome the limitations of this narrow slit of human sensuous receptivity, it will be able to rise above the perceived linearity of time and see the past and the future existing simultaneously as the present. ${ }^{49}$ Ouspensky reminds us that the past contains not only what happened but also all that could have happened. Similarly, the future consists of the myriad of possible events that together with the indeterminate past make up an unknown space, which Ouspensky believes is time - the fourth dimension of space. This time-space qualifies to be defined as a geometric fourth dimension:

By time we mean the distance separating events in the order of their succession and binding them in different wholes. This distance lies in a direction not contained in three-dimensional space, therefore it will be the new dimension of space.

This new dimension satisfies all the possible requirements of the fourth dimension on the ground of the preceding reasoning.

It is incommensurable with the dimensions of three-dimensional space, as a year is incommensurable with St. Petersburg. It is perpendicular to all directions of three-dimensional space and is not parallel to any of them. ${ }^{50}$

The illusion of motion that human beings understand as time is a symptom of the existence of the fourth spatial dimension. To human beings, whose limited faculties of perception preclude possibility of the awareness of the fourth dimension of space, time manifests itself only as motion. The other, spatial manifestation of time, remains hidden:

\begin{abstract}
It is necessary to admit that by one term, time, we designate really two ideas- "a certain space" and "motion upon that space." This motion does not exist in reality, and it seems to us as existing only because we do not see the spatiality of time. That is, the sensation of motion in time (and motion out of time does not exist) arises in us because we are looking at the world as if through a narrow slit, and are seeing the lines of intersection of the time-plane with our three-dimensional space only. ${ }^{51}$
\end{abstract}

Or to put the matter more exactly, the contact with a certain space of which we are not clearly conscious calls forth in us the sensation of motion upon that space; and all this taken together, i.e., the unclear consciousness of a certain space and the sensation of motion upon that space, we call time. ${ }^{52}$

In his definition of the fourth dimension, Ouspensky emphasizes the existence of space upon which human perceptual apparatus perceives the illusion of motion. The phrase "motion upon space" brings to mind the conventional for the current reader definition of the fourth dimension as time, proposed by Einstein. Thus, without stressing the spatial nature of time, Ouspensky's 
time as space can be confused with Einstein's time that, even though intimately connected with the three spatial dimensions, is non-spatial itself.

At least on one occasion, the declarative and lucid style of Malevich's writing indicates that the artist intended his ideas on the fourth dimension to be correctly interpreted. This instance is related to Malevich's preparations of the text that would be known as Cubism (1918). In what appears to be an earlier, 1916 version of this essay, Malevich writes on the fourth dimension as time, in agreement with Albert Einstein — a detail so poignantly noticed by Malevich's scholar, Alexandra Shatskikh:53

Будучи не чисто живописным направлением - на основании трехмерного построения и лепки живописной он несет в себе стремление к четвертому измерению живописных масс.

Указывая ясно путь к чистому живописному направлению т.е. к двухмерному, как живописной плоскости и четвертому т.е. ко времени движения живописного цвета в пространстве.

Being not a pure painterly direction [in art] - on the basis of the three-dimensional construction and painterly modeling, it [Cubism] bears an aspiration for the fourth dimension of the painterly masses.

Clearly pointing the path to pure painterly direction i.e. to the two-dimensions of the painterly plane and to the fourth one i.e. to the time of movement of the painterly colour in space. ${ }^{54}$

Indeed, Malevich's "time of motion of the painterly masses in space" does portray time as a measure of motion, which is taking place in space. In another version of this document Malevich, as if correcting himself, attempts to create a sense of time as space within which his painterly masses are to reside:

Хотя будучи сам не чисто живописным - на основании красочной лепки - имея в большей части своей основательный трехмерный закон - устремляясь - к четырехмерному т.е. заключении живописной формы в четырехмерном измерении - т.е. времени.

Although not being purely painterly itself - on the basis of colour modeling - having mostly fundamental, three-dimensional law - aspiring - to the four-dimensional i.e. to the enclosure of a painterly form in the fourth dimension - i.e. time. ${ }^{55}$

In Цветопись (1917) (Cvetopis'; a neologism that can roughly be translated as “writing with colour'), an unrelated to Cubism article document, which, however, was written around the same 
time, Malevich clearly demonstrates his allegiance to Ouspensky's understating of the fourth dimension as spatial time:

Цветописец < $>$ стал непосредственно перед голым материалом, из которого ему предстоит создать форму двухмерную или трехмерную (скульптур<а>). (Четвертая мера, движение во времени или же представление в изображении той части вещи, <что скрыта,> т.е. четвертой стороны, является раскрытием всех четырех сторон вещи для ясного <о ней> представления, но в это же время вещь теряет свой общий вид, так что погоня за выяснением четвертой стороны вещи выясняет ее, но разрушает вещь, ее реально<е > существованиях Мне думается, что достижение четвертого измер<ения> по отношению к четвертой стороне вещи за счет других нелепо. И убеждаюсь, что четвертая мера должна быть отнесена к<0> времени, как $5<$-я> мера к \{тепломеру\}.

The colourist stood directly in front of the bare material from which he was to create a two-dimensional or three-dimensional shape (sculpture). (The fourth measure, the movement in time, or the representation in the image of that part of the thing that is hidden, i.e., the fourth side, is the disclosure of all four sides of the thing for a clear conception of it, but at the same time the thing loses its general form, so that the pursuit of finding out the fourth side of the thing does bring one to figuring it out, but destroys the thing, its real existence. I think that the achievement of the fourth dimension with respect to the fourth side of the thing at the expense of others is ridiculous. I am convinced that the fourth measure should be attributed to time, as the 5 th measure to thermal energy\}. ${ }^{56}$

Here, Malevich equates the fourth dimension with the movement in time and not with the time of movement, as he did in the aforementioned version of the Cubism essay. Suggesting spatial configuration of time that contains motion within its plane, Malevich, further in the sentence, describes the fourth dimension as that part of a thing that is hidden, its fourth side. He blends the temporal and spatial interpretation of the fourth dimension in a manner similar to Ouspensky's. While both, Malevich and Ouspensky, regard art as the language capable of transmitting intuitions of the fourth dimension, in the discussed passage Malevich argues against using fourdimensional representation in the arts. The elusive nature of four-dimensional objects renders it impractical to create in four spatial dimensions for an artist, willing to communicate their ideas to the public that still perceives the reality of their existence as three-dimensional. This communicative barrier of spatial four-dimensional art forces Malevich to a conclusion that in the hands of artists, the fourth dimension must be treated as time. According to Malevich's 
recommendations, the art of painting should rely on a two-dimensional surface, while the art of sculpture - on three dimensions of space. When it comes to the fourth dimension of time, only one art form that so masterfully utilizes time (and that undoubtedly affected the development of Malevich's art) comes to mind - the art of cinema (Malevich's dialogue with this art form is discussed in the "Malevich and Film" chapter).

Cinema, which Malevich envisions as the perfect medium for visualizing the evolution of Suprematist shapes, is a dynamic form, while the noumena of the fourth dimension, according to Ouspensky, is static. This paradoxical relationship of the dynamism of film to the static immobility of the fourth dimension might be the reason why Malevich's infatuation with film was somewhat brief. It could be that the illusion of motion that film creates is too much in agreement with the way phenomena of three-dimensions, "the immobile angles and curves of the fourth dimension," appear to be in motion to human beings with an undeveloped spacesense.$^{57}$ For Malevich, the tension between dynamism and immobility, expressed in his choice of the static medium of painting to portray dynamic Suprematist forms, seems to have been one of the driving creative forces.

Malevich's philosophy contains multiple references to an immobile yet dynamic state of reality as non-objectivity he terms "покой," a word that can be translated as rest, inactivity, peace. In the spirit of Ouspensky's claim that "the truth... is contained in a union of two opposite understandings in one," ${ }^{58}$ Malevich states that the goal of Suprematism is to "transfer the force of the statics through the economic essence of the plane or to form a visible dynamic rest" (“передать силу статики через экономическую сущность плоскости или образовать видимый динамический покой)." 59 This “elastic, dynamically arrested movement of the Suprematist plane” (“упругое, динамически покойное движение супрематической 
плоскости") plays the main role in Suprematist painting. ${ }^{60}$ Malevich's concept of dynamic state of rest approaches Kandinsky's notion of dynamic equilibrium that for the latter was best expressed in the shape of a circle. Brought to the fullest expression of the union of the opposites, the circle becomes a point, simultaneously referring to silence and speech. ${ }^{61}$ It appears that achieving the state of loud silence that Kandinsky associates with a point is comparable to reaching the condition of rest pregnant with dynamism, which Malevich sought in Suprematist art. $^{62}$

According to Malevich, the consciousness of the new man will be directed into nonobjectivity. This movement towards the non-objective will be achieved through "dynamism of excitement or rest, the realization of which must occur through the Suprematist system as a new white realism” “динамизм возбуждений или покой, реализация которого произойти должна через Супрематическую систему как новый белый реализм."63 Malevich purposefully combines contradictory words into a phrase such as "dynamic rest” (динамический покой) to allude to the difficult task that his Suprematism faces: to express the immobile (that is not moving according to the common human understanding of what motion is) nature of the fourth dimension through the dynamism with which it is perceived in the three-dimensional world. Through dynamic Suprematist masses Malevich wants to express the eternal non-objective rest [покой] of the fourth dimension — a project that bends traditional conceptions of logic, bordering with non-sense. Contrary to expectations, this condition of illogicality and absurd is a welcomed one. As Ouspensky said, "In order to realize the new world, we must understand the new logical order of things." ${ }^{4}$ This revelation that encountering "the new order of things inevitably leads to logical absurdities"65 brings to mind Malevich's alogism and the Zaum language of Kruchenykh discussed in the chapter on Malevich and mysticism. Malevich, having grasped the logic of the 
new order, arrived at the understanding of reason beyond that dictated by the consciousness trapped in the space of merely three dimensions:

\begin{abstract}
We have come as far as the rejection of reason, but we rejected reason because another kind of reason has grown in us, which in comparison to what we have rejected, can be called 'beyond reason' [zaumnyi] which also has law, construction [konstruktsiia], and sense, and only by learning it shall we have work based on the law of the truly new 'beyond reason'.

We have arrived at beyond-reason-ness. I don't know whether you agree with me or not, but I am beginning to understand that in this beyond-reason there is also a strict law which gives pictures their right to exist. And not one line should be drawn without the consciousness of its law, then only are we alive. ${ }^{66}$
\end{abstract}

Transition to higher logic that allows to comprehend time as the fourth dimension of space should be accompanied by denunciation of matter as one of the most stubborn delusions of an undeveloped consciousness. In order for the present to expand "it would be necessary for us to liberate ourselves from matter, because matter is nothing more than the conditions of space and time in which we dwell." ${ }^{67}$ Consciousness must leave the conditions of materiality of threedimensional existence, to evolve from the dominant human form of receptivity, in which matter exists in three dimensions, in time and space. Ouspensky claims that this condition is equivalent to a form of blindness: "In speaking of matter it is necessary always to remember that matter is not a substance, but a condition. Suppose for example, that a man is blind. It is impossible to regard this blindness as a substance; it is a condition of the existence of a given man. Matter is a form of blindness." ${ }^{\prime 68}$ Ouspensky's analogy between the condition of blindness and the inability to grasp reality as a four-dimensional space brings to mind Malevich's architectons, his “blind Suprematist structures" 69 discussed in the chapter on Malevich and cosmism. The adjective "blind," which I interpreted as descriptive of the structure's lack of doors and windows, and as indicative of Malevich's rejection of objective vision, acquires a new meaning in the context of Ouspensky's Tertium Organum. It is possible that by referring to his architectons as blind, Malevich, with the wit and the sense of irony characteristic of the artist, confirms their yet inferior state of existence as matter in three dimensions. Malevich seeks the non-objective state 
of rest in which the three-dimensional objects are annihilated and all becomes undifferentiated totality. This project suggests a process in which matter abandons its objective state - a project that is in agreement with Ouspensky's call to lift the veil of material existence. Malevich writes of the practical difficulties of the realization of this project and of the persistence of material forms:

я в полном покое хочу пройти всю натуру, все бытие, не хочу вражды и тяжести. Я хочу втиснуть свой разгоряченный борьбою мозг в натуру и раствориться в ней, но несчастье мое в том, что не могу <ни> найти щели, ни придумать орудие, которое разрубило <бы> натуру, и я бы вошел-она не рубится, не растворяется, не сгорает, не замерзает, она, как ведьма, в пар обращается, и в воду, и в дерево, и в пепел; так уж сам мой разум установил ее неущемленность. Хочешь ведьму преодолеть-а она опрокинется собакой, хочешь ее ударить-она колесом пошла. В ученом мире эта ведьма неуязвима, она называется материя.

in complete peace I want to go through all of nature, all being, I do not want enmity and gravity. I want to squeeze my heated brains into nature and dissolve in it, but my misfortune is in that I can neither find a crevice, nor come up with a tool that would penetrate nature for me to enter - it does not cut, it does not dissolve, it does not burn out, it does not freeze, it, like a witch, turns into steam, and into water, and into a tree, and into ashes; so my mind itself has established its unbreachingness. If you want to overcome a witch, she will turn into a dog, you want to hit her - she rolled away like a wheel. In the learned world, this witch is invulnerable, it is called matter. ${ }^{70}$

Malevich's project of doing away with matter, an aspiration so close to that of Ouspensky, can be witnessed in the titles of Malevich's paintings presented at The Last Futurist Exhibition of Paintings 0,10 (19 December 1915 to 17 January 1916). These early Suprematist works bore such names as Painterly Realism of a Boy with a Knapsack-Colour Masses in the Fourth Dimension (1915), Painterly Realism of a Football Player-Colour Masses in the 4th Dimension (1915), Painterly Realism of a Peasant Woman in Two Dimensions (1915), Self Portrait in Two Dimensions, Automobile and Lady_Colour Masses in the 4th Dimensions (1915), and LadyColour Masses in the Fourth and Second Dimensions (1915). Material form loses its recognizable features and appears in its original, true shape-as immobile angles and curves of the fourth dimension, or, according to Malevich's terminology, as colour masses. The latter comes to sight in the recognizable shape of, for example, a boy with a knapsack and a football 
player, only when perceived with the reliance on sensations, perceptions, and conceptionsproperties of consciousness that portray reality as three-dimensional-without the assistance of the fourth property of higher intuition.

The question arises, however, regarding the resemblance of Malevich's self-portrait, which, according to the author, resides in two dimensions, and the four-dimensional colour masses of a boy with a knapsack (there could be other analogous comparisons between Malevich's 1915 paintings but we will adhere to the one just mentioned). In The Fourth Dimension and Non-Euclidian Geometry in Modern Art, Linda Dalrymple Henderson suggests that Malevich's paintings presented at the 0.10 exhibition describe three-dimensional subject matter existing in the two and four-dimensional spaces to hint at the artistic process that brings forth Suprematist art. Malevich is stimulated by his surroundings, which are situated in the habitual Euclidian space of three dimensions, but he exports his sensations of this reality into the spaces of other dimensions. Malevich declares: "In naming some of these paintings I do not wish to point out what form to seek in them, but I wish to indicate that real forms were approached in many cases as the ground for formless painterly masses from which a painterly picture was created, quite unrelated to nature." ${ }^{\prime 11}$ Malevich's statement surely explains the absence of the titles that speak of the subject matter's being depicted in the three dimensions-nature serves as the raw material for the artist. However, it does not shed more light upon the question concerning the similarity between the depictions of the subject matter derived from the phenomenal reality in two and four dimensions of space.

In his otherwise flawed paper titled A Man and His Square: Kasimir Malevich and the Visualization of the Fourth Dimensions, Stephen Luecking offers a curious supposition regarding the possible reasons for Malevich's choosing to paint shapes in two and four dimensions in an 
almost identical manner — as polygons on white background. Luecking lists a variety of analogies with which the geometry of the fourth dimension was introduced to the laymen at the turn of the twentieth century. Among the more common analogies some of which were already discussed in this chapter, Luecking brings to the fore a less frequently used analogy that deals with the intersections of two lower-dimensional objects with a higher-dimensional one. ${ }^{72}$ Thus, in a three-dimensional space the intersection of two two-dimensional planes produces a onedimensional line segment. From this postulate, it follows that in a four-dimensional space, the intersection of two three-dimensional solids will produce a two-dimensional plane. This method of establishing conceptual understanding of higher-dimensional geometry was popularized by Edwin Abbott Abbott in his satirical novella Flatland: A Romance of Many Dimensions (1884). ${ }^{3}$ Using this method, Luecking proposes that Malevich's Painterly Realism of a Boy with a Knapsack - Colour Masses in the Fourth Dimension demonstrates just that: the intersection of three-dimensional solids / human forms in a four-dimensional space produces black and red planes. Luecking also notices that the passing of a three-dimensional object through a twodimensional plane brings similar results—a slice of the three-dimensional solid or a plane. ${ }^{73} \mathrm{It}$ seems that Malevich's Self Portrait in Two Dimensions, according to Luecking, is about passing of a three-dimensional body of the artist through a two-dimensional surface of the canvas. Thus, the polygons of Painterly Realism of a Boy with a Knapsack and Self Portrait in Two Dimensions are very much alike, even though achieved through intersections of objects in four and two dimensions, respectively.

\footnotetext{
${ }^{3}$ Through depicting the difficulty with which a lower-dimensional creature perceives beings from a higherdimensional world, Flatland proposes that human inability to perceive higher-than-three-dimensional spaces might be a symptom of their existence.
} 
This curious theory, although plausible, extensively relies on the type of analytical thinking that Malevich despised. It is quite possible that Malevich, in lieu of the artist's developed sense of humor (which according to Bergson leads to intuitive insights), purposefully created this intellectual trap for those willing to get caught in the webs of their own reason. Malevich's alogism seeps through his work from the time of its inception expressed in such paintings as An Englishmen in Moscow (1914) throughout his entire carrier. Could it be then that the similarity between the three-dimensional bodies living in a four-dimensional world and the three-dimensional bodies - in a two-dimensional plane, a correspondence announced by Malevich in his 1915 paintings, is at once an artist's prank and the affirmation of a conviction that without having a developed space-sense and assistance of higher intuition one cannot share their judgments on the topic of higher dimensions?

\section{Conclusions:}

Indeed, having a coherent theory of higher dimensions of space that can allow one to be judgmental and opinionated can only be the product of a dedicated mind. Malevich's writings demonstrate this intellectual struggle, an aspiration to reconcile the variety of ideas on this puzzling topic. Even though Malevich's art contains echoes of non-Euclidian geometries and shares with them a comparable motivation to discover spaces other than the habitual threedimensional phenomenal world, it is in the geometries of the four dimensions where one can truly locate a source of Malevich's inspirations. While there are traces of spiritualistic and theosophical interpretations of the fourth dimension in Malevich's writings, an almost palpable presence of Ouspensky's thought in the artist's work is difficult to ignore. A Promethean task of rebuilding reality through restructuring of the perceptual apparatus of human beings by introducing the fourth unit of psychic life, the higher intuition, to consciousness' already present 
three - sensation, representation, concept — is a project that appears to be driving both Malevich's and Ouspensky's philosophies. Annihilation of matter, which is a symptom of a mind's not having a developed space-sense and only operating with merely three units of psychic life, is another common theme in the two thinkers' oeuvres. Most important, Malevich agrees with Ouspensky regarding the fourth dimension as time, which they both interpret as spatial. However, when it comes to practical application of this realization, Malevich prefers to treat the fourth dimension as time omitting its spatial characteristic. This, the artist states, should be done due to purely pragmatic reasons - while it is possible to work in two and three dimensions, expressing one's artistic ideas in four spatial dimensions makes the subject matter of the artwork unrecognizable and therefore uncommunicative, which cancels one of the artwork's purposes of being a transmitter of sensations. Malevich stays loyal to the metaphysical conception of the fourth dimension as noumenal reality but considers it dynamically, as non-spatial time when it comes to the practical applications of the idea of the fourth dimension in art. 
${ }^{1}$ Linda Dalrymple Henderson, The Fourth Dimension and non-Euclidean Geometry in Modern Art (Cambridge, MA: MIT Press, 2013), 105.

${ }^{2}$ A. N. Kolmogorov and A. P. IUshkevich, Mathematics of the 19th Century: Mathematical Logic, Algebra, Number Theory, Probability Theory (Basel: Birkhäuser Verlag, 2001), 76.

${ }^{3}$ Christoph J. Scriba, Peter Schreiber, and Jana Schreiber, 5000 Years of Geometry: Mathematics in History and Culture (Basel: Birkhäuser, 2015), 439.

${ }^{4}$ Ibid.

${ }^{5}$ A. N. Kolmogorov and A. P. IUshkevich, Mathematics of the 19th Century, 77.

${ }^{6}$ Kazimir Malevich, "Suprematism as Pure Knowledge" [1922], in Sobranie sochinenii v piati tomakh [Collected Works in Five Volumes] (Moscow: Gileia, 1995-2004), vol. 3, 138, (translation mine).

${ }^{7}$ Linda Dalrymple Henderson, The Fourth Dimension and non-Euclidean Geometry in Modern Art, 105.

${ }^{8}$ Arkady Plotnitsky, "Bernhard Riemann's Conceptual Mathematics and the Idea of Space," Configurations 17, no. 1 (2009): 124.

${ }^{9}$ Ibid., 111.

${ }^{10}$ Kazimir Malevich, "On New Systems in Art" [1919], in Sobranie sochinenii v piati tomakh [Collected Works in Five Volumes] (Moscow: Gileia, 1995-2004), vol.1, 162 (translation mine).

${ }^{11}$ Tony Robbin, Shadows of Reality: The Fourth Dimension in Relativity, Cubism, and Modern Thought (New Haven: Yale University Press, 2006), 5.

${ }^{12}$ Linda Dalrymple Henderson, The Fourth Dimension and non-Euclidean Geometry in Modern Art (Cambridge, MA: MIT Press, 2013), 107.

${ }^{13}$ Ibid., 171-172.

${ }^{14}$ Ibid., $165 \& 374-375$.

${ }^{15}$ B. V. Gnedenko and S. S. Demidov, Ocherki po istorii matematiki v Rossii (Moskva: OGIZ Gosudarstvennoe Izdatel'stvo Tehniko-Teoreticheskoj Literatury, 1946), 100.

${ }^{16}$ Ibid., 174. 
${ }^{17}$ I consulted the scanned copies of the magazine's issues. Vestnik opytnoj fiziki i jelementarnoj matematiki (V.O.F.Je.M.) Archive 1886-1917. Version 1.00 Full DVD Edition, Multimedia Disk, Matematicheskij institut RAN im. Steklova, 2011.

${ }^{18}$ Linda Dalrymple Henderson, The Fourth Dimension and non-Euclidean Geometry in Modern Art, 378.

${ }^{19}$ Friedrich Zöllner and Johann Carl, Transcendental Physics: An Account of Experimental Investigations from The Scientific Treatises of Johann Carl Friedrich Zöllner (London: W.H. Harrison, 1880), 6-7.

${ }^{20}$ Aleksandr Butlerov, Stat'i po mediumizmu (Sankt-Peterburg: Tip. V. Demakova, 1889), 1 (translation mine).

${ }^{21}$ Ibid., (translation mine).

${ }^{22}$ Maria Carlson, No Religion Higher than Truth: A History of the Theosophical Movement in Russia, 1875-1922 (Princeton: Princeton University Press, 2015), 27.

${ }^{23}$ Ibid.

${ }^{24}$ John E. Bowlt, "Esoteric Culture and Russian Society," in The Spiritual in Art: Abstract Painting 1890-1985, 165-83 (New York: Abbeville Press, 1986), 168.

${ }^{25}$ Linda Boersma et al., Kazimir Malevich and the Russian Avant-garde: Featuring Selections from the Khardzhiev and Costakis Collections (Amsterdam: Stedelijk Museum, 2013), 20.

${ }^{26}$ Bernice Glatzer Rosenthal, "Fashionable Occultism: Spiritualism, Theosophy, Freemasonry, and Hermeticism in Fin-de-Siècle Russia," in The Occult in Russian and Soviet Culture, ed. Bernice Glatzer Rosenthal (Ithaca, NY: Cornell University Press, 1997), 139-143.

${ }^{27}$ Annie Wood Besant, Man and His Bodies (Los Angeles, CA: The Theosophical Publishing House, 1917), 36.

${ }^{28}$ Charles W. Leadbeater, "The Fourth Dimension," Lecture, Amsterdam, April 1900, p. 4. (A lecture given by C. W. Leadbeater before the Amsterdam Lodge T.S. in April, 1900. Stenographic notes in Dutch by J.J. Hallo, Jr.; translated into English by Mrs. Marie Knothe.)

${ }^{29}$ James H. Billington, Ikona i topor: opyt istolkovaniâ istorii russkoj kul'tury (Moskva: VGBIL, 2011), $556 \& 567$.

${ }^{30}$ Charles H. Hinton, Speculations on the Fourth Dimension: Selected Writings of Charles Hinton (New York, NY: Dover Publications, 1980), 12.

${ }^{31}$ Charles W. Leadbeater, "The Fourth Dimension," 11 (emphasis original). 
32 Ibid., 14.

${ }^{33}$ Kazimir Malevich, "Exhibition of the Professional Union of Painters. Left Federation (young faction)" [1918], in Sobranie sochinenii v piati tomakh [Collected Works in Five Volumes] (Moscow: Gileia, 1995-2004), vol. 1, 121 (translation mine).

${ }^{34}$ Kazimir Malevich, "1/47. Suprematism. The World as Non-Objectivity” [1924], in Sobranie sochinenii v piati tomakh [Collected Works in Five Volumes] (Moscow: Gileia, 1995-2004), vol. 4, 166 (translation mine).

${ }^{35}$ Linda Dalrymple Henderson, The Fourth Dimension and non-Euclidean Geometry in Modern Art, 379.

${ }^{36}$ P. D. Uspenski1̌, Tertium Organum: The Third Canon of Thought; A Key to the Enigmas of the World, trans. Claude Fayette Bragdon and Nicholas Bessaraboff (New York: Alfred A. Knopf, 1922), $10 \& 262$.

${ }^{37}$ Ibid., 3.

38 Ibid., 23.

39 Ibid., 24.

40 Ibid., 25.

${ }^{41}$ Kazimir Malevich, "The World as Non-Objectivity. Part 1. Theory of the Additional Element in Painting" [1927], in Sobranie sochinenii v piati tomakh [Collected Works in Five Volumes] (Moscow: Gileia, 1995-2004), vol. 2, 75 (translation mine).

42 As quoted in John E. Bowlt, "Esoteric Culture and Russian Society," in The Spiritual in Art: Abstract Painting 1890-1985, 165-83 (New York: Abbeville Press, 1986), 172.

${ }^{43}$ Khardzhiev-Chaga Collection, Document H_0759, Stedelijk Museum Amsterdam (translation mine).

${ }^{44}$ P. D. Uspenskiĭ, Tertium Organum: Kljuch k zagadkam mira (Sankt-Peterburg: Trud, 1911), 65-66.

${ }^{45}$ P. D. Uspenskiu, Tertium Organum: The Third Canon of Thought; A Key to the Enigmas of the World, 85.

${ }^{46}$ P. D. Uspenskiı̆, Tertium Organum: Kljuch k zagadkam mira (Sankt-Peterburg: Trud, 1911), 259 (translation mine).

${ }^{47}$ P. D. Uspenski1, Tertium Organum: The Third Canon of Thought; A Key to the Enigmas of the World, 382.

48 Ibid., 39. 
49 Ibid.

${ }^{50}$ Ibid., 45 (emphases in original).

${ }^{51}$ Ibid., 46.

52 Ibid., 113.

53 Alexandra Shatskikh, "Comments and Notes," in Sobranie sochinenii v piati tomakh [Collected Works in Five Volumes] (Moscow: Gileia, 1995-2004), vol. 5, 475 (translation mine).

54 Khardzhiev-Chaga Collection, Document H_0756, Stedelijk Museum Amsterdam, 3 (translation mine).

55 Khardzhiev-Chaga Collection, Document H_0761, Stedelijk Museum Amsterdam (translation mine).

${ }^{56}$ Kazimir Malevich, "Cvetopis"” [1916-1918], Sobranie sochinenii v piati tomakh [Collected Works in Five Volumes] (Moscow: Gileia, 1995-2004), vol. 5, 67 (translation mine).

${ }^{57}$ P. D. Uspenskiū, Tertium Organum: The Third Canon of Thought; A Key to the Enigmas of the World, 115.

58 Ibid., 44.

${ }^{59}$ Kazimir Malevich, "Suprematism (From the 1915-1920 Works)" [1925], in Sobranie sochinenii v piati tomakh [Collected Works in Five Volumes] (Moscow: Gileia, 1995-2004), vol. 2, 33 (translation mine).

${ }^{60}$ Kazimir Malevich, "Exhibition of the Professional Union of Painters. Left Federation (young faction)" [1918], in Sobranie sochinenii v piati tomakh [Collected Works in Five Volumes] (Moscow: Gileia, 1995-2004), vol. 1, 122 (translation mine).

${ }^{61}$ R. Bruce Elder, Harmony and Dissent: Film and Avant-garde Art Movements in the Early Twentieth Century (Waterloo, Ont.: Wilfrid Laurier University Press, 2010), 156.

${ }^{62}$ On loud silence of a point, see Wassily Kandinsky, Point and Line to Plane (New York: Solomon Guggenheim Foundation, 1947), 25.

${ }^{63}$ Kazimir Malevich, "The World as Non-Objectivity. Part II. Suprematism as Non-Objectivity" [1927], in Sobranie sochinenii v piati tomakh [Collected Works in Five Volumes] (Moscow:

Gileia, 1995-2004), vol. 3, 241 (translation mine).

${ }^{64}$ P. D. Uspenskiu, Tertium Organum: The Third Canon of Thought; A Key to the Enigmas of the World, 246.

65 Ibid. 
${ }^{66}$ As quoted in Charlotte Douglas, Swans of Other Worlds: Kazimir Malevich and the Origins of Abstraction in Russia (Ann Arbor, MI: UMI Research Press, 1980), 52.

${ }^{67}$ P. D. Uspenskiū, Tertium Organum: The Third Canon of Thought; A Key to the Enigmas of the World, 49.

${ }^{68}$ Ibid., 237.

${ }^{69}$ Kazimir Malevich, "Letter from Malevich to El Lissitzky, 14 August 1924, Nemchinovo," in Malevich o Sebe, Sovremenniki o Maleviche: Pis'ma, Dokumenty, Vospominaniia, Kritika: V 2kh Tomakh, eds. I. A. Vakar and T. N. Mikhienko, (Moskva: RA, 2004), vol. 1, 160.

${ }^{70}$ Kazimir Malevich, "1/40 Painterly Experience" [around 1923], in Sobranie sochinenii v piati tomakh [Collected Works in Five Volumes] (Moscow: Gileia, 1995-2004), vol. 4, 28 (translation mine).

${ }^{71}$ As quoted in Linda Dalrymple Henderson, The Fourth Dimension and non-Euclidean Geometry in Modern Art, 422.

72 Stephen Luecking, "A Man and his Square: Kasimir Malevich and the Visualization of the Fourth Dimension," Journal of Mathematics and the Arts 4, no. 2 (2010): 96.

${ }^{73}$ Ibid., 98. 


\section{Chapter 3: Malevich and Infinity}

\section{Introduction:}

Kazimir Malevich has actively explored the concept of the infinite in his writings and in his white paintings of 1918-1919, associating the infinite with the colour "white." He writes:

At the moment, a person's path lies through space; suprematism, the semaphore of colour-in its infinite abyss. The blue colour of the sky is conquered by the suprematist system, it was broken through, and it entered the white as a true real representation of infinity and therefore is free from the colour background of the sky. ${ }^{1}$

Around the same time that Malevich was working out the non-objective language of Suprematism in which the artist strove to articulate the relationships between the finite and the “infinite abyss" of colour, Russian mathematicians, Nikolai Luzin, Dmitri Egorov, and Pavel Florensky, have been wrestling with the implications of set theory at the basis of which was an aspiration similar to Malevich's - to attain the knowledge of the infinite. In a way, Malevich's Suprematism is also aroused by an ambition to overcome the problems of set theory. Exposing logical contradictions at the basis of set theory, Russell's Paradox triggered developments in mathematics that contributed to the unfolding of what is commonly referred to as the crisis of modern reason. ${ }^{23}$ It is this crisis that stimulated avant-garde practices that sought to find lost harmony and revive the spirit circumcised by calculative reason. ${ }^{4}$ Interpreted in such manner, the aforementioned Russian mathematicians' and Malevich's projects can be understood as reactions against the crisis of modern reason expressed in mathematical and visual languages, respectively. What is particularly striking about these seemingly different approaches to studying infinity, the mathematical and the visual, is that both appear to be founded on treating infinity as actually existing, as a complete totality that can be subjectively experienced in the physical world. Egorov, Luzin, Florensky, and Malevich's approach to the problems of modernity is to take a theurgist stance to creative practices and to synthesize mathematical ideas with mysticism,- 
especially of the sort found in Name Worshippers' movement—affirming that it is possible to create infinities that through the act of creation become actually existing. Similar aspirations can be found in Russian Symbolist art and are especially well pronounced in the work of the poet, Andrei Bely, the student of Egorov and the classmate of Luzin and Florensky. From his mathematical mentors influenced by the mysticism of the Name Worshippers, Bely must have borrowed understanding of poetic creation as life imbuing. He writes: "When I name an object with a word, I thereby assert its existence." ${ }^{5}$ This conviction that created artistic forms actually exist and bear characteristics of life is fundamentally important for Malevich. I contend that at least partially, it is connected with the developments in mathematics that led to treating infinities as actually existing. To understand how Malevich and the aforementioned Russian mathematicians came to treat infinity as such, one needs to undertake a short excursion into the history of the concept of the infinite. This excursion is followed by an introduction of the ideas of the Name Worshipping sect, which, I argue, have contributed to Malevich's understanding of art as a process that brings forth life.

\section{Brief History of Infinity:}

From a bird's eye view and with a momentary indulgence in teleological understanding of history, it appears that the intellectual transformations of the concept of actual infinity were moving towards the climactic developments in its theorizing, which took place on the verge of the centuries, in the work of Georg Cantor, laying the foundation for the achievements of Luzin, Egorov, and Florensky. My proposition that the developments of the Russian School of Mathematics have influenced Malevich's understanding of infinity makes the study of Cantor and of the aforementioned mathematicians fundamentally important for my project. 
If we descend towards the time of the genesis of the Western understanding of infinity, its history can be said to begin with the Greek term apeiron ( $\ddot{\alpha} \pi \varepsilon \imath \rho \circ v)$, often translated as unbounded, infinite, indefinite, and undefined. The latter meaning of the word reflects apeiron's cosmological roots. In Greek cosmology, the world was born out of original chaos, of apeiron. ${ }^{6}$ This rather pejorative connotation of the infinite is reflected in Plato and Pythagoras' rejection of infinity rooted in the thinkers' convictions that the world is finite and can be represented through a finite sequence of natural numbers. For Plato, the ultimate form, the Good, is, too, finite and definite. $^{7}$

Aristotle, who is often considered the father of modern science, expressed acute concern for the empirical investigations of the physical world, and recognized that the study of physics involved analysis of categories that were either limited or unlimited: time and space do seem to expand indefinitely, pointing at the actuality of apeiron. This contradiction between the actuality of the infinite and the a priori finite world of the Greeks must have motivated Aristotle to buttress the dominant worldview with the more restricted notion of potential infinity. The latter allowed avoiding the dangerous actual infinite by claiming that it doesn't exist. Since it is never complete, it is bound to remain in a state of perpetual movement to the next value, as a mere potentiality that never reaches the limit. ${ }^{8}$ This account of the infinite as processive can be considered truly revolutionary, as it had been in opposition to the dominant worldview that considered the infinite to be a perfect, all-inclusive totality. Aristotle's conception of the infinite has come to prevalence in the domains of physics and mathematics, forbidding the entrance of actual infinity into the language of mathematics until the middle of the $19^{\text {th }}$ century.

Even though Aristotelian approach to infinity would come to dominate Western science, there was somewhat of a reaction against Aristotle and a reversion to the ideas of Plato-an 
intellectual movement that found expression in metaphysics and Christian philosophy. Interestingly, both of these approaches to infinity, the mathematical and the metaphysical, would later converge in the work of Georg Cantor, fundamentally altering the history of mathematics.

It was Plotinus who seems to have first connected the ideas about God and infinity and emphasized the immeasurable nature of the former in his writings. Being a follower of Plato, Plotinus deemed it important to resurrect the distinction between the physical reality immediately available to the senses and the transcendental, ultimate reality of Platonic Forms that only the inner eye can see. The philosopher interchangeably used various names to describe the underlying reality, an Eleatic "The One," a Platonic "The Good," and the name for the infinite that would become preferred by the later theologians - "God." The ineffability of the First Principle that resulted in the plurality of names ascribed to It by Plotinus, also brought about a radical change in the conception of infinity. In Plotinus' Neoplatonism, the derogatory meaning of the infinite as something lacking form and undefined is substituted for one in which God's limitless nature is celebrated. No form is capable of containing the One, self-sufficient in its vastness that no human imagination is capable of grasping. Plotinus says: "The One, perfect because it seeks nothing, has nothing, and needs nothing, overflows, as it were, and its superabundance makes something other than itself." ${ }^{\prime 9}$ This overflowing (it must be noted that Plotinus uses emanation as a metaphor and, in his writings, clearly indicates that it should not be understood literally) creates his "first born," Intelligence, which becomes such only when it turns towards the One and becomes filled with It, reaching the state of perfection. ${ }^{10}$ It is this "turning" that gives form to the infinity produced by the overflowing of the One. Intelligence, when inundated with the goodness of the One, creates Soul, whose subsequent overflowing produces the sensible universe. 
Interestingly, ideas reminiscent of the One and of the ultimate reality would become fundamentally important for Malevich. It seems that with Plotinus, Malevich shared a pluralistic approach of naming the unifying force that moved the world. For the artist, God, too, was not immediately related to any static form of deity, but was ineffable power, creative force. Malevich, as if writing about Plotinus' the One and Intellect states:

God - the power, the life of which consists in the eternal work of modification of forms, and in this eternally creative power lie or, rather, it is divided into two clearly separate forces, which, however, exist together only (they live); the first force is unconscious, the second conscious (two together are the Great Intellect). Unconscious force creates and changes a form; conscious - designs it for life (Schopenhauer was not correct when acknowledging this will as unconscious and all creation as unconscious expression of the will). All in nature has intellect and is consciously designed without interference for each other; everything is calculated and nothing is omitted. ${ }^{11}$

I propose that Malevich's Neoplatonic infinity as the unbounded First principle is mathematically connected with the ideas of Georg Cantor, who too was inspired by mystical understanding of infinity as God and invented mathematical language that was to assist him in comprehending Its unboundedness. Among the thinkers in whom Cantor found support for his conviction in the actual existence of infinity was Friedrich Leibniz, who proposed that actual infinity can be found in the infinite divisibility of nature. Leibniz, who most certainly was influenced by Neoplatonic thought, must have been inspired by the dialogue in Parmenides, a text by Plato that motivated Plotinus to develop his strain of anti-Aristotelian metaphysics, which supports the idea of the infinite divisibility of matter:

Then being is distributed over the whole multitude of things, and nothing that is, however small or however great, is devoid of it? ... And it is divided into the greatest and into the smallest, and into being of all sizes, and is broken up more than all things; the divisions of it have no limit. ${ }^{12}$

This proposition that actual infinity can be found in nature, becomes reincarnated in the seventeenth century by Leibniz:

I am so in favor of actual infinite that instead of admitting that Nature abhors it, as is commonly said, I hold that Nature makes frequent use of it everywhere, in order to show more effectively the perfections of its Author. Thus I believe that there is no part of matter which is not - I do not say divisible - but actually divisible; and consequently the least particle ought to be considered as a world full of infinity of different creatures. ${ }^{13}$ 
It is difficult to say whether Malevich has consulted any writings by Leibniz, but analogies in thought between Leibniz and Malevich can be drawn. Malevich understands the world as a series of nested universes: the universe of the cosmos contains the human world, in which each human, in turn, consists of a universe of creatures. Even though the artist doesn't stress the infinite character of this series, he does emphasize the idea of divisibility of nature into smaller elements: "Man is a universe as well. In it, there also live billions of lives, which use and destroy him. Similarly, this man will act on the ball on which we live."14

Seventeenth century was marked by the concept of infinity becoming more dominant in mathematics and sciences, bringing metaphysics and mathematics into conflict regarding the place of God. Among those claiming infinity for God alone was George Berkeley, who criticized calculus as a doctrine that found expression in Newtonian theory of fluxions and the Leibnizian infinitesimals. The concept of infinitely expanding Newtonian space threatened theological monopoly on infinity as well. ${ }^{15}$ This surely was the time of experimentation with ideas on how to interpret the mathematical and scientific findings in such a way as not to contradict the word of God. ${ }^{16}$ Isaac Newton, too, engaged in a metaphysical excursion, which brought him to a conviction that actual infinity does exist.

Interestingly, the idea of Newtonian space, associated with mathematization and rationalization of physical space, was strongly linked to a motivation to understand God. For Newton, God and space are interrelated for the physical space is a sensorium of the omnipresent God—an unusual and highly contested position at the time. In Principia Mathematica, Newton writes:

Space is an affection of a being just as a being. No being exists or can exist which is not related to space in some way. God is everywhere, created minds are somewhere, and body is in the space that it occupies; and whatever is neither everywhere nor anywhere does not exist. And hence it follows that space is an emanative effect of the first existing being, for if any being is posited, space is posited. ${ }^{17}$ 
Newton infers that existence necessarily involves occupation of space-a logical consequence of existence of any being. It follows that space must be an emanation of the first existing being, or God. Newton's emanative principle of space is akin to Plato's conception of the emanation of the Good that fills the inner eye, philosopher's soul, with wisdom. Similarly, God emanates space and fills it with his presence that is everywhere at all times. Since God always is, space is eternal as well: there never was or will be an occasion at which God ceases to exist and to occupy the emanated space. God's eternity results in consistent existence of space, without beginning or end. This iconoclastic idea of the intimate connection between God and space brought Newton to an even more radical proposition - that space is actually infinite. For Newton, this proposition is a logical outcome of the actual infinity of the omnipresent God, who must occupy an actually infinite space, being actually infinite himself. Common notion that space is only potentially infinite would render Newton's God potentially infinite as well, an assumption Newton could not agree with. In Newton's philosophy, the only way to comprehend the actual infinity of God is to merge God with an infinite Euclidean space. ${ }^{18}$

Newton's unwillingness to discuss the topics of metaphysics in relation to the sciences, something that was a staple of natural philosophers prior to Newton, played a trick on him. The force of attraction, which for Newton was evidence of His actions upon the space He inhabited, was the manifestation of God's omnipresence in the world; it has ceased to be regarded as such and became a secularized force of nature, a characteristic of matter, that enriched mechanistic theories of life instead of displacing them. ${ }^{19}$ Space became the infinite void, filled with lifeless matter that moves in eternal time according to strict mathematical rules without any particular purpose or meaning. 
As it had been sketched earlier in this chapter, actual infinity has undergone substantial conceptual transformations, originating in the closed world of the ancient Greeks, for whom it had a negative connotation of chaos and formlessness, becoming the actual infinity of Neoplatonic God, and, later, of space inhabited by omnipresent first principle of Newton, eventually turning into the spiritless void of infinite Newtonian space. With the exclusion of Leibniz's insistence on the infinite divisibility of matter that was bathed in his mathematical ideas, actual infinity was not used in mathematics. ${ }^{20}$ Possibly as an expression of an overarching mathematizing tendency characteristic of modern paradigm that emerged in the seventeenth century, the concept of infinity, too, started to be expressed mathematically, with Bernard Bolzano introducing the concept of actual infinity into mathematics in his book, The Paradoxes of the Infinite (1851).

In the second chapter of this book, Bolzano writes: "It is precisely in mathematics... where we speak most frequently of the infinite."21 Bolzano's Paradoxes is born out of the conviction that the lack of the proper definition of infinity lies at the origin of all paradoxical situations in mathematics. ${ }^{22}$ It is through reformulating infinity as a property of sets that Bolzano intended to save mathematics from confusion. ${ }^{23}$ Infinity for Bolzano cannot be understood as something that exists on its own, but only as a property of a set of finite elements:

... a truly infinite quantity $[\ldots]$ does not by any means need to be variable $[\ldots]$ Conversely, it is quite possible for a quantity merely capable of being taken greater than we have already taken it, and of becoming larger than any one pre-assigned (finite) quantity, nevertheless to remain at all times merely finite: which holds in particular with any numerical quantity $1,2,3,4, \ldots{ }^{24}$

This conceptual leap allows Bolzano to affirm the existence of actual infinity:

Now that we are agreed on the idea to be attached to the word infinite, and now that we have made ourselves clearly aware of the elements composing that idea, the next question to be asked is that concerning its objective existence - that is, whether there exist objects to which it can be applied, whether there exist sets which we may judge to be infinite in the sense here declared. This I venture to answer with a decided affirmative [...] The set of all 'absolute propositions and truths' is easily seen to be infinite. ${ }^{25}$ 
Bolzano's development of the concept of the infinite served as a foundation for the work of Georg Cantor, whose groundbreaking achievements led set theory to its maturity, transforming mathematics into the science of the infinite. ${ }^{26}$

Curiously, Malevich's description of the infinite, which he has been actively exploring in his 1918-1919 white paintings, is surprisingly close to how the founder of set theory, Georg Cantor, defined a set. Malevich describes his visceral journey into the infinite: "I saw myself in space, hidden in dots and bands of colour; there among them I sank into the abyss. ${ }^{27}$ According to Emmy Noether, a contemporary of Cantor, here is how the founder of set theory visualized a set:

As to the concept of a set, Dedekind said he regards a set as a pursed sack, a sack that contains certain specific things, but you do not see them and know nothing of them other than that they are specific and present. Some time later, Cantor gave his own idea of a set. He draw himself up to full height, described with his arm a grandiose gesture, and, with inscrutable gaze, breathed: "I visualize a set as an abyss." 28

Cantor fully transformed actual infinity into a mathematical object and embedded it into the language of mathematics. Very roughly summarized, Cantor's revolutionary approach to the study of actual infinity consisted of performing arithmetic operations on finite and infinite sets, the counting of which led him to his breakthrough discovery of transfinite numbers. ${ }^{29} \mathrm{In}$ December 1873 , Cantor proved that the set of integers $\mathbb{N}$ and the set of real numbers $\mathbb{R}$ differed in their respective number of elements - the event that marked the beginning of set theory. Taking into account that mathematicians did not operate with the actual infinite prior to Cantor's discovery, having to consider that there was not simply one actual infinity, but two, was surely a radical idea at the time.

Cantor's aspiration to know the infinite was guided by his theological concerns, for he associated the infinite with God and desired to grasp its perfection through speaking the language of infinity, which he invented in the form of transfinite numbers. Malevich connected the infinite 
with non-objectivity and imagined that the evolution of humanity should come to a state of complete objectlessness and elimination of traditional notions of time and space. Infinity will be defeated by non-objectivity and humanity will have to give up such notions as the past and the future. Malevich explains:

Let us assume that in many thousands or millions of years humanity will attain omniscience, hence, will reach the state of being everywhere. What will this moment be like? There will be nothing to comprehend and nothing to know, and, obviously, there will be nothing to do. The world is open, and its entire being stands in knowledge, the universe in all its greatness and infinity of its creations will move according to its eternal law of motion, and already all its movement is a part of my knowledge and its every phenomenon is infinitely calculated. Having attained such perfection, we will reach God, namely the image that humanity has predetermined in its legends or in actuality. Then, the beginning of a new divine inactivity, non-being, disappearance of personhood will arrive, for the humanity will enter into that greatest image of its perfect predestination. ${ }^{30}$

Thus, joining the infinite in its non-objective endlessness and indefiniteness is the ultimate state of perfection in Malevich's view of human evolution.

Malevich and the Russian School of Mathematics:

Whether he was familiar with it or not, Cantor's set theory could not assist Malevich in grasping the infinite for it contained within itself a paradox, an intellectual abyss that undermined the foundations of mathematics. Through the specific ways of probing this abyss, arguably created by the same cultural conditions that spurred the developments in the avant-garde art, the new creative freedoms were discovered in Suprematism and set theory in Russia; freedoms that enabled thinkers to not only know the infinite but to create it. It is the emphasis on the reality of existence of the objects created in the visual art of Malevich and in the mathematics of Nikolai Luzin, Dmitri Egorov, and Pavel Florensky that I would like to briefly focus on here.

In his writings, Malevich frequently affirms his conviction in the reality of the art forms he creates, with probably the most famous example being Malevich's Black Square, to which the artist refers to as a "royal living infant." ${ }^{31}$ Malevich defines works of art not concerned with the imitation of nature as those that contribute living forms to the already existing ones, creating new 
species. Only when colours are released from the confines of lines that depict nature on a canvas

and form themselves into painterly arrangements motivated by the artist's intuition, can a

painting be considered a living plane. The artist explains:

But paint was in the oppression of the common sense, was enslaved by it. And the spirit of the paint was weakening and dying away. But when it defeated the common sense, the colours poured on the forms of real things they so hated. The paints have ripened, but their forms in the consciousness have not. That's why the faces and bodies were red, green and blue. But this was a harbinger, leading to the creation of selfdetermined pictorial forms. Now you need to arrange the body and give it a live appearance in real life. And this will happen when the forms come out of the picturesque masses, i.e. will arise just as utilitarian forms arose. Such forms will not be the repetition of living things in life, but will themselves be a living thing. The painted plane is a living real form. ${ }^{32}$

In figurative painting, which copies the visible world, Malevich sees only death, an empty vessel devoid of life:

Only a few still recognize representational art as art—aesthetic act, worrying about expressing the object or a portrait in a harmonious combination of pictorial relations, to express a picture not of an object, but to frame the object into a picture. The artist, in dealing with nature, has this goal - in such an action we do not see creativity, in which painting can participate. Adding a creative sign that will be a living picture - will be a living member of the entire living world, - every image of nature in the artistic frame will be like a dead person decorated with fresh flowers. ${ }^{33}$

Malevich's consideration of Suprematist forms as real and alive cannot be traced to any particular source. It is most probable that these beliefs seeped into the artist's consciousness through becoming acquainted with the vitalist ideas of Henry Bergson and the panpsychist thought of Konstantin Tsiolkovsky. I contend, however, that at least partially these convictions of Malevich were formed in dialogue with the ideas found in the philosophy of name, propagated by Pavel Florensky, Aleksei Losev and Sergei Bulgakov, who in turn were influenced by the popularity of the name-worshipping sect among Russian intelligentsia. ${ }^{1}$

At the root of the name-worshipping practice lies a realist conviction that in the name of God called in the prayer, God himself is present, or, using the language of the name worshippers,

\footnotetext{
${ }^{1}$ This was wonderfully demonstrated in relation to the mathematical work of Egorov, Luzin and Florensky in Naming Infinity.
} 
“The Name of God is God." Among the most devoted supporters of the movement was Pavel Florensky — a priest, historian, philosopher, scientist, and mathematician, whose intellectual contact with the Russian avant-garde must have stimulated the spread of the importance of naming beyond academia and religious practices into literary and artistic traditions. Malevich, too, seems to have been informed of the discourses around naming that occupied intelligentsia at the time. In the following quote the artist, as if simultaneously referring to Florensky and Cantor, mentions both a priest and a scientist:

Hence the whole culture of human "perfection," "scientific and visual justifications." The simple action, the first, scientific, lies in giving names to the unknown, which is neither plural, nor singular. All science is like a priest who, baptizing in the name of Unknown, unfamiliar to him God, gives the name to the baby. Also a scholar, operating with an unknown infinite, gives a name, dividing it into elements. ${ }^{34}$

Florensky's commitment to the ideals of Name Worshipping has inspired his Moscow University professor, mathematician Dmitri Egorov, and instilled spiritual curiosity in the latter's colleague, Nikolai Luzin, influencing the emergence of a new mathematical field of descriptive set theory. For the Russian mathematicians, the process of naming and describing mathematical entities was equaled with giving them life imbued with all the characteristics of actual existence. ${ }^{35}$

Florensky suggests that the first steps towards accepting the existence of the actual infinite in nature and in God should be through admission of the infinite in spirit or in abstracto. Thus, gaining awareness of the abstract, spiritual infinity takes the central position within the hierarchy of the epistemological quest towards knowing the infinite in all its forms. ${ }^{36}$ Cantor and Florensky's abstract way of gaining insight into the Absolute and the Transfinitum is through creation of the symbols of the infinite - transfinite numbers. Malevich's in abstracto is through invention of the non-objective, abstract (otvlechennyi) symbols of Suprematism. The artist states: "Suprematist figures or forms are built only in space and convey its infinite abyss, without giving any impression that they themselves come from the earth or have gravitation toward it." 37 
Malevich stresses the newness of forms that artistic consciousness should create and concretize on a canvas. Similarly, the mathematicians working in set theory create new infinities. The infinity of Malevich's White on White can be said to be a visual analogue of a mathematical infinity described by Luzin — both are creations that actually exist and can be experienced in the physical world according to the convictions of their authors. Even though there are apparent analogous motivations in the works of the Russian mathematicians and of Malevich, the latter's writings contain what appears to be a disagreement with the ideas explicated in the philosophy of the name. To be precise, there is no evidence pointing at Malevich having read Florensky's texts. However, the ideas around naming were in the air and Malevich's writing that expressed this seeming antagonism demand to be examined. In what seems to be a polemic tone, Malevich writes:

To create a real world, the society [Malevich uses the word общежитие (obshhezhitie, community housing), which implies a lack of privacy and a condition of shared ideology that such living environment often entails] gave the unknown a name and [that] made the unknown real.... Will the name be a real authenticity? It seems to me that it will not... Hence, the arising of the human life built under the conditions of the names, there is no other reality this society can have (in fact, there is another reality concealed behind the sub-consciousness). ${ }^{38}$

And elsewhere:

But, obviously, a person could not otherwise live among the phenomena of nature outside of the knowledge of "objects," and painting became, like the entire work of man, the process of acquiring knowledge of nature. Without entering into any professional functions, the man gave a name to every phenomenon, and after giving to all their names, as it were, the world has become truly known to humanity, registered and with prescribed functions. But through the description of the phenomena's actions the rest of the mystery was also exhausted. ${ }^{39}$

Malevich describes the detrimental consequences of the human need to name every unknown phenomenon, restricting and limiting its potential through the process of definition and classification. Malevich, whose Suprematism is to return humanity into the state of nonobjectivity, cannot agree with a project that is opposed to his - to segregate phenomena from the totality of all undifferentiated, fused things and initiate them into their objecthood. This is the project of science, according to Malevich: 
By giving a name to every phenomenon, science still had in mind the fact that through the name of the scientific registry it would establish the boundaries of a known unit, singling it out from the common nameless fusion. And then only in science (still in representation) it became its clear function and, consequently, professional, understandable, scientifically grounded unit. And from that moment on, the real world, as a whole, inseparable in a dense or empty heartbeat, began to disappear, culture, the world as atomization, came into view in the scientific rationales of division-atomizations. ${ }^{40}$

To take a closer look at the seeming contradiction between the ideas of Malevich and the philosophy of the name, it is necessary to revisit Florensky's interpretation of the concept of the name, the basis of which is the realist and mystical conviction that the Name of God is God. Name-worshippers were in opposition to nominalism and rational materialism of traditional church (imyaborzy), which proposed that the name of God is only an indexical pointer, a sign, devoid of divine presence. Nominalism and rationalism of imyaborzi is akin to those of the sciences, which too are predisposed to subjectively assigning names to phenomena. The latter proclivity is exactly what Malevich is opposed to, making it possible to assume that the artist, in fact, shares the ideas expressed in the philosophy of the name so popular among the Russian set theoreticians.

Florensky writes, "The task of name-worshiping, as some intellectual creativity, is to express the primordial sense of humanity ... and, therefore, to reveal the ontological, epistemological and psychophysiological prerequisites of this all-human sensation and selfperception.." ${ }^{\prime 1}$ Defined as such, Florensky's philosophy approaches that of Malevich, who writes, "Suprematism is the end and the beginning, when sensations become naked, when Art becomes as such, without face. Suprematist Square- the same element as the dash of primitive man, which in its repetition subsequently expressed the sensations not of ornament, but only of rhythm.." ${ }^{\prime 2}$ And if we remember that the Jesus prayer of the name-worshippers is a rhythmic incantation that is to attune the body to its divine rhythms, establishing unity with God, resemblances with Malevich's rhythmic Suprematism become even more pronounced.

In addition, the theurgic component of the name-worshippers and the freedom associated 
with this act of creation — one is free to create God through pronouncing his name — can be found in Malevich's recognizing the infinite freedom of an artist-creator:

Before the inventor there definitely are the barriers of the dependency on overcoming the obstacles and adjusting to the requirements of needs and necessities. Before the creator, they do not exist from the consideration that he is free, but being free can be only that, which does not feel boundaries or obstacles. ${ }^{43}$

Georg Cantor, whose mathematics of infinity in its mysticism was akin to a painterly study of the infinite undertaken by Malevich, famously said, "the essence of mathematics lies in its freedom."44 This saying found expression in the mathematician's creatively unrestrained approach to mathematics where he founded and named an entire series of infinities, or even infinity of infinities. This creative aspect of freedom in mathematics finds full expression in the work of Luzin, Egorov, and Florensky, who immersed themselves into the problems of set theory, which granted them unpredictable and startling results.

\section{Conclusions:}

What I contend is important for the study of Malevich's understanding of infinity and of space, is the Russian mathematicians' conviction that by naming new infinities they give life to them-a belief based in their affiliation with the religious heretic practices of the Name Worshippers. This birthing of infinities by the Russian mathematicians closely resembles Malevich's conceptualization of creative process as the painting of realities that exist not as a symbol or a sign, but as objectively existing worlds of their own. This creative act of bringing forth mathematical and painterly objects, such as the infinities of Luzin's A-sets and infinity of Malevich's White on White, can be viewed as a result of a peculiar conceptual metamorphosis, in which infinity is viewed as the life-producing first principle which itself has become a product of the creative activity of its children. 
${ }^{1}$ Kazimir Malevich, "Suprematism. From 'The Catalog of the Tenth State Exhibition. Nonobjective Creation and Suprematism," in Sobranie sochinenii v piati tomakh [Collected Works in Five Volumes] (Moscow: Gileia, 1995-2004), vol. 1, 150 (translation mine).

${ }^{2}$ It was the time when mathematicians were particularly eager to find reassurance that mathematics had solid foundations, with Bertrand Russell and Alfred North Whitehead embarking on this project by deducing mathematics from logic, for which they relied on Cantor's set theory. It was while working on the Principia Mathematica, the three-volume book on the foundations of mathematics that even after a decade-long work was never completed, Russell disturbingly discovered a paradox that undermined Cantor's set theory and with it the soundness of mathematics itself (R. Bruce Elder, Dada \& Surrealism, 35). When considering classes that are not members of themselves and asking whether the class of such classes is or is not a member of itself that Russell arrived at a conclusion that either answer is contradictory. A similar contradiction can be created by giving a person a piece of paper that states: "The statement on the other side of this paper is false", while the other side states: "The statement on the other side of this paper is true" (R. Bruce Elder, Dada \& Surrealism, 35).

${ }^{3}$ R. Bruce Elder describes these developments in Chapter 1 of Dada, Surrealism, and the Cinematic Effect.

${ }^{4}$ R. Bruce Elder, Dada, Surrealism, and the Cinematic Effect (Waterloo, Ont.: Wilfrid Laurier University Press, 2013), 23.

${ }^{5}$ Loren R. Graham and Jean-Michel Kantor, Naming Infinity: A True Story of Religious Mysticism and Mathematical Creativity (Cambridge: The Belknap Press of Harvard University Press, 2009), 97.

${ }^{6}$ Rucker, Rudy V. B. Infinity and the mind: the science and philosophy of the infinite (Princeton, NJ: Princeton U Press, 2005), 3.

${ }^{7}$ Donald Davidson, Plato's Philebus (New York: Routledge, 2013), 308.

${ }^{8}$ Michael J. Smith, "Aristotle on the Infinite, Space, and Time," in A Companion to Aristotle (Oxford: Wiley-Blackwell, 2013), 261.

${ }^{9}$ David J. Yount, Plotinus the Platonist: A Comparative Account of Plato and Plotinus' Metaphysics (London: Bloomsbury Academic, 2016), 108.

${ }^{10}$ Ibid.

${ }^{11}$ Khardzhiev-Chaga Collection, Document H_758, Stedelijk Museum Amsterdam.

12 Plato, Parmenides 144, in The Dialogues of Plato: Translated into English, with Analyses and Introductions, trans. Benjamin Jowett (New York: Macmillan and Co., 1892), 70. 
${ }^{13}$ Joseph Warren Dauben, Georg Cantor: His Mathematics and Philosophy of the Infinite (Princeton, NJ: Princeton University Press, 1990), 124.

${ }^{14}$ Khardzhiev-Chaga Collection, Document H_758, Stedelijk Museum Amsterdam.

${ }^{15} \mathrm{~W}$. Breidert, "Berkeley's defence of the infinite God in contrast to the infinite of mathematics," in Mathematics and the Divine: A Historical Study, 499-509 (Amsterdam: Elsevier Science, 2005), 503-504.

${ }^{16}$ For example, the famous mathematician and theologian, John Wallis, illustrated the Holy Trinity in terms of a three-dimensional cube, where the cube represents the unity of the trinity and its three dimensions - length, breadth, and height — stand for the Father, the Son, and the Holy Ghost (ibid., 504).

${ }^{17}$ As quoted in Andrew Janiak, Newton as Philosopher (New York: Cambridge University Press, 2008), 141-142.

${ }^{18}$ Andrew Janiak, Newton (Chichester, West Sussex: Wiley Blackwell, 2015), 167.

${ }^{19}$ Alexander Koyre, From the Closed World to the Infinite Universe (Radford, VA: Wilder Publications, 2007), Kindle, Kindle Locations 3444-3447.

${ }^{20}$ Samuel Levey, "Leibniz on Mathematics and the Actually Infinite Division of Matter," The Philosophical Review 107, no. 1 (January 1998): 50.

${ }^{21}$ Bernard Bolzano and Steve Russ, The Mathematical Works of Bernard Bolzano (Oxford: Oxford University Press, 2004), 600.

${ }^{22}$ Guillermina Waldegg, "Bolzano's Approach to the Paradoxes of Infinity: Implications for Teaching," Science \& Education 14, no. 6 (2005): 564.

${ }^{23}$ Ibid., 565.

${ }^{24}$ Bernard Bolzano, Paradoxes of the Infinite (Routledge Revivals) (London: Routledge, 2014), 80 .

${ }^{25}$ Ibid., 84.

${ }^{26}$ See Hermann Weyl on mathematics as "the science of the infinite" in Levels of Infinity [1930].

${ }^{27}$ Marion Ackermann and Isabelle Malz, Kandinsky, Malewitsch, Mondrian: Der weisse Abgrund Unendlichkeit $=$ The infinite white abyss (Koln: Snoeck Verlagsgesellschaft $\mathrm{mbH}$, 2014), 251.

${ }^{28}$ R. Thiele, "Georg Cantor (1845-1918)," in Mathematics and the Divine: A Historical Study, 523-548 (Amsterdam: Elsevier Science, 2005), 542. 
${ }^{29}$ Ibid., 528.

${ }^{30}$ Kazimir Malevich, "Laziness_-The Real Truth of Humankind" [1921], in Sobranie sochinenii $v$ piati tomakh [Collected Works in Five Volumes] (Moscow: Gileia, 1995-2004), vol.5, 183, (translation mine).

${ }^{31}$ Kazimir Malevich, "From Cubism and Futurism to Suprematism" [1915], in Sobranie sochinenii v piati tomakh [Collected Works in Five Volumes] (Moscow: Gileia, 1995-2004), vol.1, 53 (translation mine).

${ }^{32}$ Ibid., 49.

${ }^{33}$ Kazimir Malevich, "On New Systems in Art” [1919], in Sobranie sochinenii v piati tomakh [Collected Works in Five Volumes] (Moscow: Gileia, 1995-2004), vol.1, 163 (translation mine).

${ }^{34}$ Kazimir Malevich, "Suprematism as Non-objectivity” [1922], in Sobranie sochinenii v piati tomakh [Collected Works in Five Volumes] (Moscow: Gileia, 1995-2004), vol.3, 316 (translation mine).

${ }^{35}$ Loren Graham and Jean-Michel Kantor, Naming Infinity, 96.

${ }^{36}$ Pavel Florensky, "On the Symbols of the Infinite (An Outline of G. Cantor's Ideas)" [1904], in Sobranie sochinenii v chetyreh tomakh [Collected Works in Four Volumes] (Moscow: Mysl', 1994), vol. 1, 87.

${ }^{37}$ Kazimir Malevich, “A Note around 1914,” in Sobranie sochinenii v piati tomakh [Collected Works in Five Volumes] (Moscow: Gileia, 1995-2004), vol. 5, 384 (translation mine).

${ }^{38}$ Kazimir Malevich, "Suprematism as Pure Knowledge" [1922], in Sobranie sochinenii v piati tomakh [Collected Works in Five Volumes] (Moscow: Gileia, 1995-2004), vol. 3, 208 (translation mine).

${ }^{39}$ Ibid., 126.

${ }^{40}$ Ibid.

${ }^{41}$ As quoted in A. Oleksyuk, "Filosofiya Imeni P.A. Florenskogo [P.A. Florensky's Philosophy of Name]," Vestnik MGOU 'Filosofskie Nauki' 4 (2009): 166 (translation mine).

42 Kazimir Malevich, "The World as Non-objectivity. Part II. Suprematism” [1927], in Sobranie sochinenii v piati tomakh [Collected Works in Five Volumes] (Moscow: Gileia, 1995-2004), vol. 2, 110 (translation mine). 
${ }^{43}$ Kazimir Malevich, "Suprematism as Pure Knowledge" [1922], in Sobranie sochinenii v piati tomakh [Collected Works in Five Volumes] (Moscow: Gileia, 1995-2004), vol. 3, 80 (translation mine).

${ }^{44}$ As quoted in P. Cartier et al., Freedom in Mathematics (New Delhi: Springer, 2016), 10. 


\section{Chapter 4: Malevich and Imaginary Numbers}

Introduction:

This chapter draws parallels between Malevich's understanding of Suprematism as a prism that focuses objective vision allowing one to grasp what lays beyond its limits, beyond zero, and Florensky's interpretation of imaginary numbers that proposes the existence of the reverse side of reality, where space is imaginary, objects have imaginary mass, and time moves backward. It claims that Florensky's ideas on imaginary numbers, which the philosopher/mathematician has been discussing since 1902, found expression in Malevich's philosophy of non-objectivity. Florensky's work Mnimosti v Geometrii (Imaginaries in Geometry, 1922) contains the germ of zero symbolism that has evolved not only into the ideas of Andrei Bely and Aleksei Kruchenykh, whose writings have inspired Malevich, but also into Malevich's zero philosophy. Mnimostiv Geometrii is a work that offers a novel approach to understanding the geometry of imaginary numbers, which are the product of multiplication of a real number, such as "five," by an imaginary unit $i$, whose square equals negative one $\left(i^{2}=-1\right)$. In order to fully appreciate Florensky's mathematical masterstroke and to grasp the connections between the imaginary space, occupied by the imaginary numbers, and the space of Suprematism, it is necessary to take a brief tour of the major historical events concerning the development of the ideas surrounding these mathematical entities.

Brief History of Imaginary Numbers:

Exploration of the world of numbers usually begins with the introduction of natural (positive, whole numbers used for counting and ordering), integer (all numbers without a fractional component), rational (numbers expressed as a fraction of two integers), and real numbers (includes rational and irrational numbers, such as $\sqrt{2}$, or $\pi$ ). Even though most of the known 
numbers belong to the aforementioned group(s), there are species that seem to have visited from another realm. One of such puzzling numbers is the mathematical entity $\sqrt{-1}$ that is usually denoted by the letter $i$, which stands for the word "imaginary," and is derived from the equation $x^{2}+1=0$. Attempts to determine the value of the variable $x$ lead to the following result: $x=$ $\sqrt{-1}$. For centuries, this mathematical outcome was either ignored or considered an impossible "mental torture."1 The struggles to comprehend how the square of $x$, which by definition must be a positive number, can possibly equal to a negative value, were far from futile, leading to the development of the complex number plane and the use of $i$ in space-time physics, electrical engineering, and theoretical and applied mathematics.

The first to ignore the square root of a negative number was Heron of Alexandria, who, in the first century A.D., upon providing a correct formula for determination of the volume of the pyramid with square base, $h=\sqrt{c^{2}-2\left(\frac{a-b}{2}\right)^{2}}$, chose to test it with the lower base being equal 28 , the upper- 4 , and the edge -15 . Heron's calculations stated: $h=\sqrt{15^{2}-2\left(\frac{28-4}{2}\right)^{2}}=$ $\sqrt{225-2(12)^{2}}=\sqrt{225-144-144}=\sqrt{81-144}$. But instead of writing that $\mathrm{h}=$ $\sqrt{-63}$, Heron opted for the inoffensive $\sqrt{63}$, completely disregarding the existence of the square root of a negative number and failing to become the first known mathematician to have derived this value from an analysis of a physical problem. ${ }^{2}$

Divorced from its connection with physical reality, the square root of a negative number received a lot more attention. Among the first mathematicians, who dared to use this puzzling number in calculations was Girolamo Cardano, who published his solutions to the cubic and biquadratic equations, that is equations such as $x^{3}+x=10$ and $x^{4}+3 x^{2}=4$, in his 1545 book Ars Magna. Cardano's seemingly innocent problem that read as "Find two numbers that add up to 10 
and give 40 when they are multiplied together" brought him face-to-face with the square root of a negative number, $\sqrt{-15}$ in this case. If converted to algebraic notation, the problem requires finding solutions for the following equations: $x+y=10$ and $x y=40$. Cardano's method for solving such equations involves substitution of the $y$ in the second equation with the $y$ from the first, which equals $10-x$, giving $x(10-x)=40$. Using the quadratic formula $\mathrm{x}=\frac{-b \pm \sqrt{b^{2}-4 a c}}{2 a}$ — a formula that Cardano was familiar with — allowed the mathematician to obtain the two roots of the equation: $\mathrm{x}=5+\sqrt{-15}$ and $\mathrm{x}=5-\sqrt{-15}$. Even though Cardano didn't consider the square root of negative fifteen a number, he nonetheless wrote: "Putting aside the mental tortures involved, multiply [these quantities]. Hence the product is $40 .{ }^{\prime 3}$ While not ignoring or expressing fear towards these mathematical entities, Cardano regards square roots of negative numbers as questionable: "So progresses arithmetic subtlety the end of which, as is said, is as refined as it is useless." About a century later, in his L'Invention nouvelle en l'agebra (1629) Albert Girard argued for the acceptance of these numbers upon posing a question "Of what use are these impossible solutions?" Girard, in a rather pragmatic way, reasoned that the solutions that involve the square roots of negative numbers should be welcomed because there are simply no other solutions. This mode of thinking resulted in one of the still-to-this-day accepted definitions of a number that states that a number is a solution to an algebraic equation. ${ }^{5}$

There is, however, another understanding of numbers, one that relates them to the physical world. This geometric definition proposes that a number is the length of a geometric magnitude. It is precisely this understanding of numbers that prevented Heron of Alexandria mentioned earlier from noticing the notorious square root of a negative number. If he had, his findings would have contradicted the commonly accepted notion that a volume of a figure in space cannot be a negative value. The intuition that the algebraic and geometric conceptions of 
numbers relate to different mathematical systems is supported by the futility of attempts to create a square with an area that equals the area of a given circle (this is commonly referred to as squaring the circle.) In 1882, German mathematician Ferdinand von Lindemann determined that neither $\pi$ nor its square root are algebraic numbers, which provides an explanation for the impossibility of finding solutions to the aforementioned problem. ${ }^{6}$ Kazimir Malevich, however, seemed to have approached this problem in his 1927 film script "Artistic and Scientific FilmPainting and Architectural Concerns-Approaching the New Plastic Architectural System," where his "royal infant," black square, transformed into a circle through rotation, cinematically solving the perplexing mathematical problem. (Interestingly, the stamp for Vitebsk's UNOVIS [abbreviation for the Champions of New Art], a union of young vanguard art students led by Malevich since 1920 to 1922 , is a red square enclosed by a circle.) Similarly to the way Malevich merged the square and the circle in his film script — an act that approaches a synthesis between an algebraic and geometric conceptions of number - this chapter is concerned with how the square root of negative one, an algebraic entity that had no geometric interpretation, has breached the divide between algebra and geometry and gained spatiality. This development in mathematics has had a tremendous effect on the Russian avant-garde artists of the early twentieth century, including Kazimir Malevich, and therefore deserves our closest attention.

The square root of negative one, or $i$, acquired geometric representation on 10 March 1797, in the work of a Norwegian land surveyor, Caspar Wessel. His paper titled "On Analytic Representation of Direction: An Attempt" was presented at the Royal Danish Academy of Sciences and published in the Academy's Memoirs in 1799. Wessel's groundbreaking work, however, did not have an immediate impact, possibly due to its being written in Danish and not translated to other languages. ${ }^{7}$ It was rediscovered much later, in 1895, long after Jean-Robert 
Argand and Johann Carl Friedrich Gauss have independently arrived at similar conclusions in 1806 and 1831, respectively (in fact, Gauss had made his discoveries in 1796, prior to Wessel,

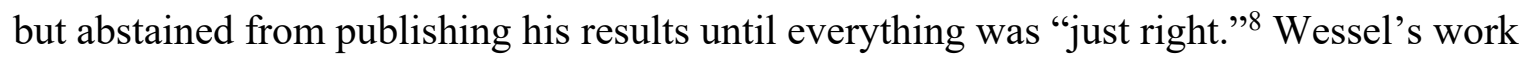
contained an interpretation of complex numbers - any numbers that can be expressed in the form $a+b i$, where $a$ and $b$ are real numbers, and $i$ is the imaginary number, for example $2+3 i$ (or $2+$ $3 \sqrt{-1}$ ). The elegance of Wessel's solution relies on the proposition that since the square root of negative one cannot be located on the number line it is necessary to extend the number line to a number plane by taking another, perpendicular to the conventional number line axis that would represent multiples of $\sqrt{-1} .^{9}$ (Note the striking similarity between the description of the new spatial plane hosting complex numbers and Ouspensky's conceptualization of the fourth dimension of space as time, whose plane is perpendicular to the other three dimensions of space.)

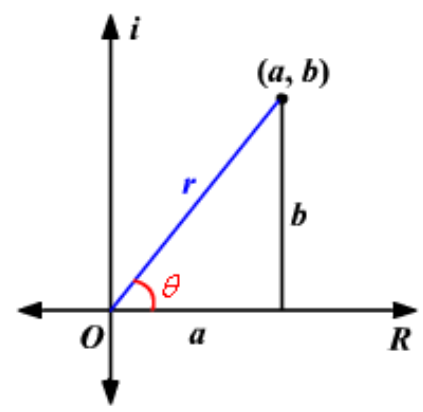

Figure 4.1: Polar form of a complex number.

For Wessel then, a complex number is a point in this newly proposed number plane known as complex plane; it can also be understood as a directed radius vector from the origin to that point. ${ }^{10}$ To understand how Wessel arrived at his simple yet brilliant geometric interpretation of $i$ it is necessary to convert $i$ to its polar form, expressed in terms of the length of the radius vector and the polar angle, which is the counterclockwise angle from the $\mathrm{x}$-axis. Thus, in polar form a complex number is expressed as $r\{\cos \theta+i \sin \theta\}$, which can also be written $\operatorname{as~}^{\mathrm{r} \tan ^{-1}}\left(\frac{b}{a}\right)$ 
and as $\mathrm{r} \angle \theta$. To find the radius, $r$, we can use the Pythagorean theorem: $r=\sqrt{a^{2}+b^{2}}$. A complex number takes the form $a+b i$. In the special case of $i, a=0$ and $b=1$. Knowing the values of $a$ and $b$, we can determine that $r$ equals 1 (since $\sqrt{0^{2}+1^{2}}=1$ ). To find the angle $\theta$, we need to think of $a$ as a value along the $\mathrm{x}$-axis and $b$ as a value along the $\mathrm{y}$-axis. Since we know that $a$ equals zero, we have a point on the positive axis $y$, which implies that $\theta=\frac{\pi}{2}=90^{\circ}$. Using the values of $r$ and $\theta$, we can express $i$ in polar form, $i=\sqrt{-1}=1 \angle 90^{\circ}$. This equation states that $\sqrt{-1}$ is the directed line segment with the length of one points straight up along the vertical axis. Geometrically, multiplying by $\sqrt{-1}$ is simply a counterclockwise rotation by $90^{\circ}$ a property that gave $\sqrt{-1}$ an additional meaning $(\sqrt{-1}$ is also an imaginary number) of the rotation operator. ${ }^{11}$

Florensky and Imaginary Numbers:

Acceptance of square roots of negative numbers not only as solutions to algebraic equations but also as geometrical magnitudes, albeit existing in an imaginary plane, was an important intellectual milestone, the one that would stimulate the imagination of avant-garde artists two centuries after Wessel first thought of the solution to the geometric interpretation of $i$. It can be said that complex number theories truly blossomed with the development of non-Euclidian geometries, which can partially explain the excitement around the idea of the imaginary plane among the Russian vanguard artists exploring new conceptions of space. Pavel Florensky, a polymath, priest, and an artist also discussed in the chapter on Malevich and Infinity, was among the thinkers who offered a strikingly original and unprecedentedly holistic theory of imaginary numbers.

In Mnimosti v Geometrii (Imaginaries in Geometry) (1922, the majority of the work was already written in 1902; Florensky discussed it with Luzin then ${ }^{12}$ ), Florensky argues against a 
reductivist approach to complex number mathematics: instead of interpreting functions themselves, it is the variables that are interpreted. The complex plane as defined by Wessel, Argand, Gauss and others, is only useful for expression of function's content, its “material cause," while neglecting function's form, its "formal cause." ${ }^{13}$ Florensky alludes to Aristotle's four causes for a reason — he seeks unified knowledge of geometric space, the one that fits into the larger picture of the world, of metaphysics. In geometry, Florensky's unifying task is to extend the two-dimensional representation of geometric entities to include imaginary numbers, which have been graphed independently since the foundation of their geometric interpretation. ${ }^{14}$ Florensky states: "In short, it is necessary to find a place in space for the representation of the imaginaries, and without taking anything away from the representation of the real numbers that already claimed their places." ${ }^{15}$ Objecting to taking points as the units studied in geometry, Florensky begins the narrative of his argument by asserting the necessity of positing the plane as the fundamental unit of geometrical analysis. Through a series of demonstrations that involve determining an area of a triangle using matrices, Florensky arrives at the mainspring of his work on the imaginaries: an area of a triangle can be either positive or negative depending on the placement of the triangle's coordinates within the matrix. Similarly to Wessel's insight into the rotational properties of $i$, Florensky concludes that the change in the sign of the triangle's area is the result of either some motion of the triangle ${ }^{16}$ or of the spectator in relationship to the triangle. ${ }^{17}$ An area with the negative sign indicates that the triangle under consideration is observed from its behind, suggesting that an observer undertook a $180^{\circ}$ trip around the triangle to face its back. Florensky explains:

Новая интерпретация мнимостей заключается в открытии оборотной стороны плоскости и приурочении этой стороне-мнимых чисел. Мнимый отрезок относится, согласно этой интерпретации, к противоположной стороне плоскости; там находится своя координатная система, в одном случае совпадающая с действительной, а в другом-расходящаяся с нею. Для нас теперь, повторяем, плоскость стала прозрачной, и мы видим обе системы осей зараз, так, что можем 
представить плоскость так, как это сделано на чертеже 15-м, где пунктиром проведена мнимая система осей.

A new interpretation of the imaginaries consists in discovering the reverse side of the plane and in associating this side with imaginary numbers. The imaginary segment refers, according to this interpretation, to the opposite side of the plane; there is its own coordinate system, in one case coinciding with the real, and in the other, divergent with it. For us, now, we repeat, the plane has become transparent, and we see both axes systems at once, so that we can represent the plane in the same way as it is done in the drawing 15 , where the dotted axis is the imaginary axis system. ${ }^{18}$

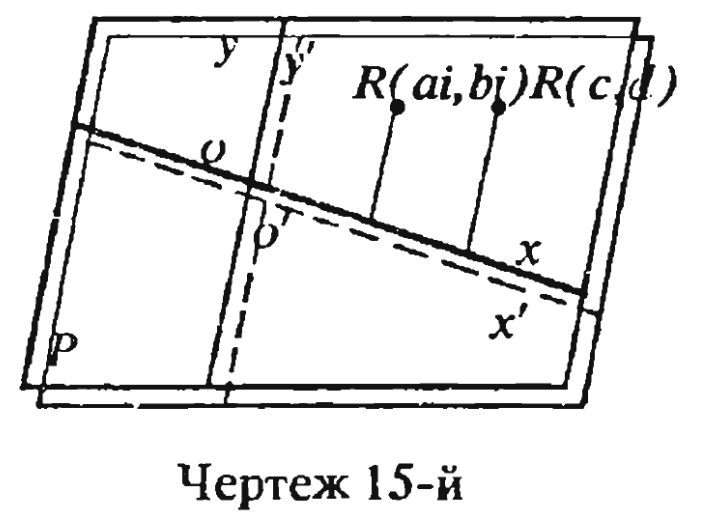

Figure 4.2: Florensky's depiction of the reverse side of reality.

Florensky's discovery of the reverse side of a plane, the one that contains the imaginary numbers, brings to mind Malevich's graph titled The Graph of the Movement of Creative Units in Infinity (1919-1923). This graph, I contend, contains subtle hints at Malevich's intent to communicate his conviction that creativity originates in the imaginary space. Usually, when creating a sketch in three dimensions, a draftsman depicts the system of coordinates facing the viewer, as it is demonstrated in the figure below. Malevich, however, rotates his coordinate system by 180 degrees, so that their axes are pointing away from the viewer. This prompts a question whether Malevich intended to provide the viewer with a hint that the hyperbola depicted is imaginary.

Answering this question would also corroborate my conjecture that Malevich's wording of his disagreement with the direction of Tatlin's work was founded on his knowledge of the theories of the imaginary numbers. Malevich writes: 
Татлин [...] болел в продолжении десяти лет материальной болезнью, сидя в железно стеклянных контр-рельефах [...] Я тоже был на волосок от гибели, меня ожидала та же участь, но тут подвернулся поет Крученых, написал поэму Победа над солнщем (это было в 1913 году) через которую я вышел в обратную сторону Татлину, пришел к нулю, стал делать ненужные вещи.

For ten years, Tatlin was afflicted by "material illness", being stuck in counter-reliefs made of metal and glass [...] I was also just a split second away from perishing, the same fate awaited me, but this is when the poet Kruchenykh turned up, wrote the poem Victory Over The Sun [this was in 1913], through which I came out on the reverse side of Tatlin, came to zero, started to produce useless works. ${ }^{19}$

Malevich’s “я вышел в обратную сторону Татлину” (I came out on the reverse side of Tatlin) may not simply be another example of Malevich's idiosyncratic use of language. It is plausible that Malevich, being aware of Florensky's theories, emphasized the difference between the worldviews of the two artists, which are, in Malevich's view, as insurmountable as the realities of the real and imaginary spaces. Malevich, who “прорвал синий абажур цветных ограничений” (broke through the blue lampshade of colour restrictions) ${ }^{20}$ leaving Tatlin behind, seemed to propose that his art belonged to the underside of reality, while copying phenomena of perceivable reality in art can only be the subject of materialist and objectivist artists.
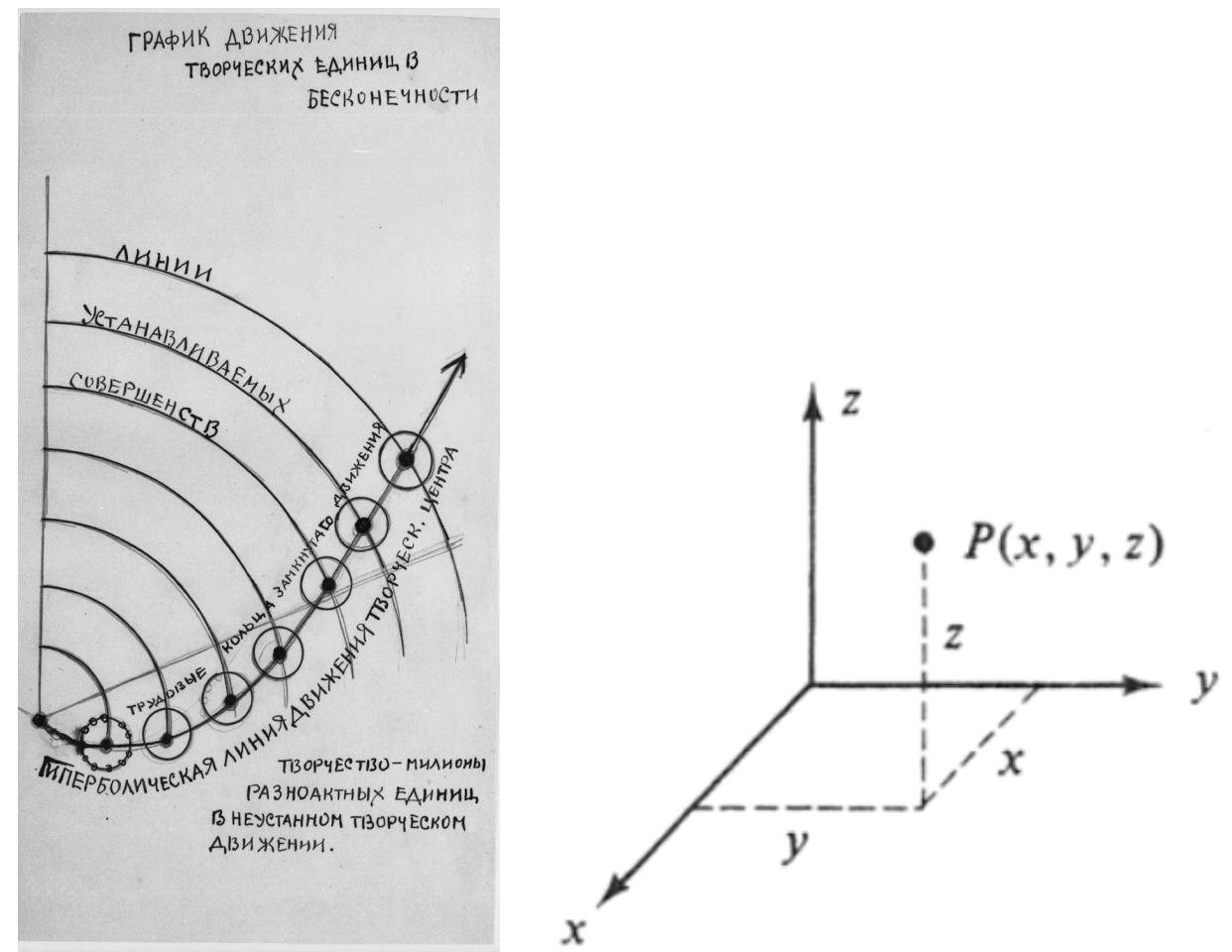

Figure 4.3: Kazimir Malevich, The Graph of the Movement of Creative Units in Infinity, 1919-1923 (left); A three-dimensional Cartesian coordinate system (right). 
Contrary to Malevich, Florensky sees the continuity between the real and the imaginary spaces: Florensky proposes that the type of the combination of real numbers with the imaginaries indicates the location of the given point in relationship to the underside of space. Florensky compares the distance these numbers traverse from the face of the real coordinates to the back of the imaginaries, to the depth of the submersion of a nail driven into a wooden plank. For example, a point with the coordinates $a, b$ is akin to a nail that is still on the surface of the plane since its coordinates' values are real numbers; while a point with the coordinates $a+d i, b i$ is akin to a nail that has been fully driven into and through the plane since its coordinates' values are a complex number and an imaginary number, both located in the underbelly of space. ${ }^{21}$ With the use of expressive metaphors-Florensky's poetic impulse seeps through in all of his workthe mathematician summarizes: “Итак, согласно предлагаемому толкованию мнимостей, кривая может уходить с лица поверхности вглубь ее толщи и тогда протекает на том или другом участке своего течения наподобие подземных рек, изображаемых на карте пунктиром,-—ттобы затем найти себе выход наружу” (So, according to the proposed interpretation of the imaginaries, the curve can go from the face of the surface deep into its thickness and then flows on this or that part of its current like the underground rivers, represented on the map by a dotted line, in order to find a way out). ${ }^{22}$

Florensky the metaphysician does not stop at the development of his truly original interpretation of the imaginary space. In the spirit of Georg Cantor's approach to the relationship between mathematics and metaphysics, Florensky's mathematics works as prosthesis with which his mind envelops reality and grasps its underlying unity and order. On its last pages, beyond discussion of abstracted notions, Florensky's Mnimosti v Geometrii reveals the author's grand 
scheme for which it is but a prelude, a vector indicating the nature of future analysis. In fact, it is these last pages of the work that are believed to have played a part in causing Florensky's premature death at the hands of the Soviet authorities threatened by the author's daring ideas. ${ }^{23}$ The core of Florensky's project introduced in Mnimosti v Geometrii is to revive the AristotelianPtolemaic-Dantean worldview crystalized in The Divine Comedy. The interpretation of imaginary numbers offered in Mnimosti v Geometrii together with the special and general principles of relativity shed a new light and provide new support for Florensky to reconsider the validity of Aristotelian-Ptolemaic-Dantean cosmology. ${ }^{24}$

According to Florensky, who also cites mathematicians George Bruce Halsted (1905) and Heinrich Martin Weber (1905) in support of his theory, Dante's Divine Comedy anticipates nonEuclidian geometry. ${ }^{25}$ Florensky's proposition is based on his analysis of Dante's text, in particular on the geometry of Dante's adventure, which begins with the poet's descent to Hell. Shaped as a funnel, it leads Dante to its narrowest place, where the poet is faced with Lucifer. At this point of the narrative, the poet's body still preserves vertical position: his head points towards the widest part of the hell funnel and his legs - towards Earth's center. However, upon reaching somewhere around Lucifer's waistline, Dante suddenly turns upside down, with his legs now pointing at the surface of Earth, where he entered the underworld, and his head - in the opposite direction. ${ }^{26}$ To contextualize the discussion, Florensky quotes the following passage from Dante's Divine Comedy:

\footnotetext{
He grasped at Satan's huge and shaggy sides, And down he went, clutching the heavy hair, Sliding over the frozen, uneven surface. When we had reached the point where Satan's hip Bulges, his haunch thickening even broader, My leader, working skillfully, but hard, Swung his head around to where his legs Had been, like someone intending to climb back up, And I was afraid he meant to return us to Hell. "Hold on," my Master told me, out of breath
} 
And panting, "for these are the only kind of stairs

We'll climb on, leaving so much evil behind us."

Then he went through an opening in the rock,

And carefully set me, sitting, just at the edge,

Then very slowly, in my direction, stepped

On past me. I lifted my eyes, thinking I saw

The Devil exactly where I had left him, but thought

I saw him, now, with his legs where his head should be-

And if, just then, I truly was bewildered,

We'll let that be said by the very dullest minds,

Those who cannot imagine the point we were climbing

Past. "Get up," my Master said. ${ }^{27}$

The trajectory of Dante's further movement is towards the mountain of Purgation formed by the force of Lucifer's fall, ascension to its peak and then, to the skies and the stars. There, upon reaching the Empyrean, and taking a look at God's glory down on Earth, Dante descends back to Florence without having to traverse any additional distance.

The mystery of Dante's movement posited as a geometrical problem lies in determining how the poet, always traveling forward, in a straight line is able to return to the same location that he has begun his adventure at. Following this line of thought, Florensky draws attention to the fact that Dante returned home in a conventional for a human orientation, with his head up. However, if Dante has not experienced his upside-down turn in Hell, he would have arrived to Florence with his head down. It follows that the plane Dante travels on is such that movement along a straight line inverting its direction once provides a return to the point of departure with no change in orientation, while an analogous movement without the inversion brings the body back in an upside-down position. Florensky concludes that the space depicted in Dante's Divine Comedy is constructed according to the principles of elliptical geometry since it agrees with the two necessary conditions: it is a Riemann surface since it contains closed lines and it is a onesided surface since it reverses orientation. ${ }^{28}$ The conceptualization of Dante's space as elliptical, Florensky states, can help explain the medieval understanding of the world as finite, which agrees with the findings of contemporary physics that space is elliptical, and that both space and 
time are finite, closed in on itself. (Actually, the consensus on whether space is finite or infinite is yet to be reached. $)^{29}$

Malevich and Zero Symbolism:

Malevich's writings are infused with propositions to abandon objective reality by annihilating form, reaching the state of zero, and travelling to the other side of this limit, merging with nonobjectivity. For Malevich, the world is dual: there is objective reality that humans inhabit and perceive with their sense organs and there is a supra-human reality of non-objectivity that requires other senses, such as intuition, to perceive it. This duality presupposes that there is a barrier that one needs to trespass to enter the world of no-thing. In this, Malevich's universe becomes similar to Florensky's resuscitated Aristotelian-Ptolemaic-Dantean cosmology, which, too, proposes the existence of the end of the world, the barrier beyond which is another realm, the realm of beyond zero. The moment of breakthrough, of climbing over the boundary of zero that separates objective reality from the one Malevich seeks to enter, is of paramount importance for Malevich's philosophy. The artist writes:

Нужно было идти дальше к полному уничтожению, к Нулю в Искусстве, и только по-за его контуром мы сможем стать с самособойным цветом как с материалом, но не с оригиналом. Здесь не приходится ни подражать, ни копировать-здесь должны создать; в уродстве лежал смысл избавиться от повторений или же был выход к непосредственному <созданию> творческих знаков.

We had to go further to total annihilation, to Zero in Art, and only beyond its contour we can become with an autonomous colour as a material, but not with the original. Here you do not have to imitate or copyyou must create here; in the ugliness lay the meaning of getting rid of repetitions or there was the way out to the immediate creation of creative signs. ${ }^{30}$

...

Преобразовавшись в быстрине смен бегущих колец горизонта, мы выпрыгнули за пределы нуля повторений, стали непосредственно лицом к лицу цвета.

Being transformed in the fast-moving shifting rings of the horizon, we jumped beyond the limits of the zero of repetitions, became directly face-to-face to colour. ${ }^{31}$

Я прорвал синий абажур цветных ограничений, вышел в белое, за мной, товарищи авиаторы, плывите в бездну, я установил семафоры супрематизма. Я победил подкладку цветного неба, сорвал и в образовавшийся мешок вложил цвета и завязал узлом. Плывите! Белая свободная бездна, бесконечность перед вами. 
I broke through the blue lampshade of colour restrictions, went into the white, follow me, comrade aviators, swim into the abyss, I installed semaphores of Suprematism. I defeated the lining of the coloured sky, tore it, put the colours into the formed bag, and knotted it. Swim! The white free abyss, infinity is before you. ${ }^{32}$

In an article 'Rejecting 'the Sun of Cheap Appearances': Journey Beyond 'Zero' with Kruchenykh, Malevich, Bely, Jakobson and Jean-Luc Godard," Nikolai Firtich notes that the “zero" symbolism, so prevalent in Malevich's thought, is also present in the works of the symbolist poet and writer Andrei Bely. In his renowned novel, Petersburg (1913), Bely, based on his conviction that there is another "higher logic" impossible to grasp with the faculty of reason, creates situations for his characters where they experience metaphysical revelations and have glimpses of this other world of "higher causality."33 The novel's protagonist Nikolai Apollonovich describes his encounter with the transcendent in the following way:

Будто какое-то откровение, что я рос; рос я, знаете ли, в неизмеримость, преодолевая пространства; уверяю вас, что это было реально: и со мною росли все предметы; и - комната, и - вид на Неву, и Петропавловский шпиц: все вырастало, росло - все; и уже приканчивался (просто расти было некуда, не во что); в этом же, что кончалось, в конце , в окончании, -- там, казалось было какое-то иное начало: законечное, что ли... Какое-то оно пренелепейшее, неприятнейшее и дичайшее, вот что-главное; дичайшее может, потому, что у меня не имеется органа, который бы умел осмысливать этот смысл, так сказать, законечный; в месте органов чувств ощущение было “ноль” ощущением; а воспринималось нечто, что и не ноль, и не единица, а менее чем единица. Вся нелепость была, может быть только в том, что ощущение было - ощущением “ноль минус нечто”, хоть пять, например.

It was as though I had a revelation that I was growing... you know what I mean, into immeasurability, traversing space; I assure you that this was real: and all objects were growing with me; the room, and the view of the Neva, and the spire of Peter and Paul; they were all swelling up, growing; and when the growing stopped (there was simply no more room left for growth anywhere, into anything); but in this fact, that it was ending, in the end, in the conclusion - there, it seemed to me, was some kind of another beginning for me: a beyond-end one, perhaps... Somehow it seemed extremely preposterous, unpleasant and deranged, - deranged - that was the principal thing; deranged, perhaps because I did not possess an organ that would have been able to make sense of this meaning, which was so to speak, beyond-end; instead of my sense organs I had a "zero" sense; and I perceived something that was not zero, and not one, but less than one. The whole absurdity was, perhaps, only that the sensation was a sensation of zero minus something - five, for example. ${ }^{34}$

The idea of “законечный” (zakonechnyi, beyond-end) can also be found in Aleksei Kruchenykh, whose Zaum language, literally translated as beyond-sense or beyond-reason, brings to mind Bely's descriptions of the existence of another kind of sense, “"zero' sense," necessary to 
function in the land beyond the end of the world. Indeed, Firtich traces the genealogy of the zero symbolism to the ideas of the symbolist poet Andrej Bely, whose philosophy of zero reached Kruchenykh's imagination through his communication with the formalist critic Roman Jakobson, who was fond of Bely's novel Petersburg. Firtich suggests that the impulse to transgress reason and objective boundaries of reality expressed in Kruchenykh's libretto to the futurist opera Victory Over the Sun was inspired by Bely's Petersburg and, in turn, prompted Malevich to develop the non-objective language of Suprematism founded on the zero of form, Black Square. ${ }^{35}$ In the passage mentioned earlier in this chapter, Malevich confirms Firtich's outline of the genealogy of zero symbolism when he explains that it was, indeed, Kruchenykh's libretto that unveiled the world beyond zero to the artist. Malevich writes:

For ten years, Tatlin was afflicted by "material illness", being stuck in counter-reliefs made of metal and glass [...] I was also just a split second away from perishing, the same fate awaited me, but this is when the poet Kruchenykh turned up, wrote the poem Victory Over The Sun [this was in 1913], through which I came out on the reverse side of Tatlin, came to zero, started to produce useless works.

This telling quote demonstrates that Malevich's aspiration to create non-objective, non-utilitarian works can be traced to his active role as a collaborator on the futurist opera Victory Over the Sun, and, in particular, to Kruchenykh's philosophy expressed in the opera's libretto. However, even though grateful to Kruchenykh for saving him from the task of making useful things, which according to the artist is a deadly endeavor, Malevich, in his "I came out on the reverse side of Tatlin," appears to nod in the direction of Pavel Florensky. Thus, to Firtich's convincing trajectory of zero symbolism in Russian art (Bely—Kruchenykh—Malevich), I would like to add the paramount importance of the ideas of Florensky ${ }^{1}$ (Florensky—Bely—Kruchenykh—

\footnotetext{
${ }^{1}$ Florensky almost certainly inspired Bely's ideas on transcending the limit of zero- - the two were engaged in fruitful correspondence that followed their first meeting in fall 1903 at the house of prof. N. B. Bugaev, father of Andrei Bely (Bely's real name is Boris Bugaev) and Florensky's university professor of mathematics (See: P. Florenskij, Obretaja Put'. Pavel Florenskij v Universitetskie Gody, volume 2, p. 482).
} 
Malevich), for Florensky's work Mnimosti v Geometrii (Imaginaries in Geometry, 1922) can be considered the founding text of zero philosophy. ${ }^{2}$

The analogies between the depictions of space in the aforementioned opera Victory Over the Sun and Florensky's analysis of space in Dante's Divine Comedy cannot be purely accidental: both are infused with allusions to reality that disobeys the rules of logic, rejecting the postulates of Newtonian physics and Euclidian geometry. In the final act, Kruchenykh describes such reality, emphasizing the non-Euclidian arrangement of space, absence of gravity, the reversed movement of time, and the loss of permanence of human bodies. This land beyond zero called the Tenth Country (Firtich proposes that Malevich's first exhibit of Suprematist works titled " 0.10 " was to suggest a connection with the idea of the Futurist Tenth Country ${ }^{36}$ ) is theatrically expressed with the help of Malevich's decorations, the instructions for which state:

“изображены дома наружными стенами но окна странно идут внутрь как просверленные трубы много окон, расположенных неправильными рядами и кажется что они подозрительно движутся" (The houses are represented by exterior walls but the windows strangely go inside like drilled pipes many windows are located in the wrong rows and it seems that they are suspiciously moving). ${ }^{37}$ The description of the building's windows as creating an appearance of motion while somehow being directed inside the structure betrays a geometric space that is reminiscent of n-dimensional elliptic geometry.

Kruchenykh emphasizes that the space of the Tenth Country is enclosing the characters of the opera in such a way that they cannot escape: "10-ыя страны... окна все внутрь проведены дом загорожен живи тут кк [sic] знаешь. Ну и 10-ыя страны! вот не знал что

\footnotetext{
${ }^{2}$ Besides the aforementioned thinkers, the theories of imaginary numbers have inspired the art and writing of El Lissitzky and the poetry of Velimir Khlebnikov and Daniil Kharms, among others.
} 
придется сидеть взаперти" (The Tenth Countries... the windows are all inside the house is fenced off live here as you know. Well, the 10th countries! I did not know that I would have to be locked up). ${ }^{38} \mathrm{He}$ also writes: “все дороги перепутались и идут вверх к земле а боковых ходов нет" (all roads are messed up and go up to the ground and there are no side passages). In a space where no lines are parallel, and all lines intersect—some of the major characteristics of elliptical space - roads can become confusing. The absence of side passages is also revealing: in an elliptical space there are no sides since it is a one-sided surface. Moreover, this suffocating space of the Tenth Country contains areas that are upside down-Florensky has described a similar anomaly in the space of Dante’s Divine Comedy. Kruchenykh writes: “ба, ой упаду (заглядывает в разрез часов: башня небо улицы вниз вершинами—кк [sic] в зеркале)" (bah, oh I am about to fall (peers into the cross-section of a clock: the tower the sky the streets are with their peaks upside down-like in a mirror) ${ }^{39}$ The spaces of Dante's Divine Comedy as explicated in Florensky's Mnimosti v Geometrii and of Kruchenykh's libretto for the Victory Over the Sun portray many similarities that betray the two as representations of what can be an earlier and a later model of elliptical geometry.

Malevich, working on the set designs for the opera, was required to truly engage with the geometrical concepts contained in Victory Over the Sun to be able to successfully materialize the strange environment of the Tenth Country. His designs were meant to confuse the sense of space by replicating in the stage backdrops the geometric shapes present in the costumes, making the human form mingle with its environment. Triggering a sensation of temporal inconsistencies, Malevich's innovative use of lighting, which involved activating spotlights in a continuous motion, subjected the stage composition to endless variation. ${ }^{40}$ Malevich's attempts at creating an illusion of space where objects are not always contained by their boundaries, time is not 
linear, and movement transforms all form can be understood as an aspiration to create a nonEuclidian elliptical space of n-dimensions.

For Florensky and Malevich the land beyond zero is not science fiction - its existence is almost a science fact. The thinkers' true concern is the possibility of knowing the conditions of existence that are beyond the confines of reality human consciousness is able to perceive.

Florensky admits that in order to experience the space beyond space one needs to travel with a speed faster than the speed of light—a requirement that may yet be unimaginable but potentially possible:

Что собственно значит предельность величины $3 \times 10^{10} \mathrm{~cm} /$ сек? Это значит вовсе не невозможность скоростей равных и больших $c$, а-лишь появление вместе с ними вполне новых, пока нами наглядно не представимых, если угодно трансцендентных нашему земному, кантовскому опыту, условий жизни; но это вовсе не значит, чтобы таковые условия были немыслимы, а может быть, с расширением области опыта,-—и представимыми.

What the limit of $3 \times 10^{10} \mathrm{~cm} / \mathrm{sec}$ actually means? This in no way means the impossibility of the velocities equal to and greater than $c$, but only the emergence, together with them, of completely new, not yet imaginable, transcendental to our earthly Kantian experience, conditions of life; but this does not mean that such conditions were unthinkable. Perhaps, with the expansion of the field of experience they will become imaginable. ${ }^{41}$

Florensky's conviction that it is going to be possible to experience conditions of living that are transcendent to our earthly experiences and that are lived at the speed that is faster than the speed of light, is reflected in Malevich's fascination with speed and dynamism that conquer space and time:

Мы, тов. Устинов, летим с неимоверной быстротой, мы опередили скорость машин, техника как культура прошлого и все культуры перед нами мамонты, мы бежим так быстро, что никакие таксометры не в состоянии мерить наше движение. Я могу сказать - мы пережили машину как скорость, для нас нужен новый символ скорости [что же < мыслью, достигшей того, что Солнце и время - наше], и в наше время исторический лоб если не разлетится вдребезги, то порядочно набьет себе шишек в бегстве за учетом.

We, Comrade Ustinov, are flying with an incredible speed, we outstripped the speed of cars, technology as the culture of the past and all the cultures before us are mammoths, we run so fast that no taximeters can measure our movement. I can say - we outlived the car as speed, we need a new symbol of speed [what is the unfortunate technology capable of in comparison with thought, which has accomplished the fact that the Sun and time are ours], and in our time the historical forehead, if not shattered, will acquire sufficient number of bumps in flight for accounting. ${ }^{42}$ 
Even though Florensky states that it is not yet possible to imagine the conditions of existence in space beyond the limits of our universe, he nonetheless attempts to predict these conditions using scientific reasoning. For example, on the border between the Earth and the Sky, following medieval representation of the end of the universe that accords with the Aristotelian-PtolemaicDantean worldview Florensky sought to revive, the length of any object becomes equal to zero, mass becomes infinite, while the time observed from away becomes infinite as well. Beyond this border, however, time flows in inverted fashion, while the length and mass of objects become imaginary. $^{43}$

Similar conditions prevail in Victory Over the Sun's Tenth Country: inhabited by people released from the weight of memories and cut off from the umbilical cord of gravity, human beings lose their substance and merge with the emptiness of space:

трус: что же осталось что-нибудь?

--- ни следа

--- глубока ли пустота?

--- проветривает весь город. Всем стало легко дышать и многие не знают что с собой делать от чрезвычайной легкости.

...

(Чтец):

как необычайна жизнь без прошлого

С опасностью но без раскаяния и воспоминаний...

Забыты ошибки и неудачи надоедливо пищавшие в ухо вы уподобляетесь ныне чистому зеркалу...

coward: what's left, is there anything?

--- not a trace

--- is the emptiness deep?

--- airs the whole city. It has become easy for everyone to breathe and many do not know what to do with the extreme lightness.

...

(Reader):

how extraordinary life is without a past

With danger but without remorse and memories...

Forgotten are the mistakes and failures annoyingly squeaking in your ear, you are now like a clean mirror... ${ }^{44}$

The lightness of being ascribed to the absence of gravity, dissolution of the past, and the destruction of the object expressed in the symbolism of a pure mirror, mirror without 
reflection - the symbolism that would be become utilized in Malevich's Suprematist Mirror

manifesto in 1923 - are the major characteristics of Kruchenykh's portrayal of the land beyond

zero. This literary experiment, which, as we have seen, inspired Malevich to develop his

Suprematist philosophy, contains mathematical ideas that are strikingly similar to Florensky's

work on imaginary numbers, the foundation for Florensky's vision of the architecture of the

cosmos.

It is with the grand vision of the cosmos and of breaking through the boundary that

separates the real space we inhabit from the imaginary unknown space of the beyond that

Florensky concludes his Mnimostiv Geometrii. I would like to quote at length a paragraph from

this conclusion, for there are many parallels to Malevich's ideas, many striking similarities not

only philosophical but also visual—Florensky's words paint the reality of Suprematism:

Но, имея в виду предлагаемое здесь истолкование мнимостей, мы наглядно представляем себе, как, стянувшись до нуля, тело проваливается сквозь поверхность-носительницу соответственной координаты, и выворачивается через самого себя,-почему приобретает мнимые характеристики. Выражаясь образно, а при конкретном понимании пространства-и не образно, можно сказать, что пространство ломается при скоростях, больших скорости света, подобно тому, как воздух ломается при движении тел, со скоростями, большими скорости звука; и тогда наступают качественно новые условия существования пространства, характеризуемые мнимыми параметрами. Но, как провал геометрической фигуры означает вовсе не уничтожение ее, а лишь ее переход на другую сторону поверхности и, следовательно, доступность существам, находящимся по ту сторону поверхности, так и мнимость параметров тела должна пониматься не как признак ирреальности его, но-лишь как свидетельство о его переходе в другую действительность. Область мнимостей реальна, постижима, а на языке Данте называется Эмпиреем. Все пространство мы можем представить себе двойным, составленным из действительных и из совпадающих с ними гауссовых координатных поверхностей, но переход от поверхности действительной к поверхности мнимой возможен только через разлом пространства и выворачивание тела через самого себя. Пока, мы представляем себе средством к этому процессу только увеличение скоростей, может быть скоростей каких-то частиц тела, за предельную скорость $c$; но у нас нет доказательств невозможности каких-либо иных средств.

But, referring to the interpretation of the imaginaries proposed here, we visualize how, by contracting to zero, the body falls through the surface - the carrier of the corresponding coordinate - and turns out through itself, acquiring imaginary characteristics. Expressed figuratively, and, with a concrete understanding of space, not figuratively, we can say that space breaks at speeds greater than the speed of light, just as air breaks with the motion of bodies, whose velocities are greater than the speed of sound; and then qualitatively new conditions for the existence of space, characterized by imaginary parameters, emerge. But, as the fall of a geometric figure [through the surface] does not at all mean its destruction, but only its transition to the other side of the surface and, consequently, accessibility to beings on the other side of the surface, the imaginary parameters of the body should not be understood as a sign of its unreality, but only as a certificate of its transition to another reality. The realm of imaginary things is real, comprehensible, and in Dante's language is called Empyrean. We can imagine the entire space as a double 
space, made up of real and of coinciding Gaussian coordinate surfaces, but the transition from the surface of the real to the imaginary surface is possible only through a breakdown of space and the eversion of the body through itself. For now, we imagine to ourselves a means to this process only through an increase in the velocities, maybe the velocities of some particles of the body, beyond the limiting velocity $c$; but we have no evidence of the impossibility of any other means. ${ }^{45}$

Florensky's "contracting to zero, the body falls through the surface," is curiously alike

Malevich's "we jumped beyond the limits of the zero of repetitions." The importance of zero as a marker of the border between the real and imaginary spaces, the objective physical reality and Suprematist non-objectivity, is, indeed, one of the common themes in Malevich and Florensky. Both speak of the transformation of form that passes through nothingness into a qualitatively different space. Florensky's 1902 (published in 1922) description of how "the body falls through the surface" to become completely transformed in the not yet imaginable conditions of the space beyond the real echoes Malevich's 1915 proclamation that the artist has "transformed into the zero of form and went beyond $0-1$ "46 (read as "zero minus one"). A similar allusion to a geometrically unthinkable space, a reality where something can be subtracted from nothing can be found in Bely's Petersburg mentioned earlier: "The whole absurdity was, perhaps, only that the sensation was a sensation of zero minus something - five, for example." It appears that both Malevich, and Bely before him, were interested in acquiring the taste of what Florensky so poignantly describes as falling through the surface, arriving on the other side of zero-the underbelly of reality.
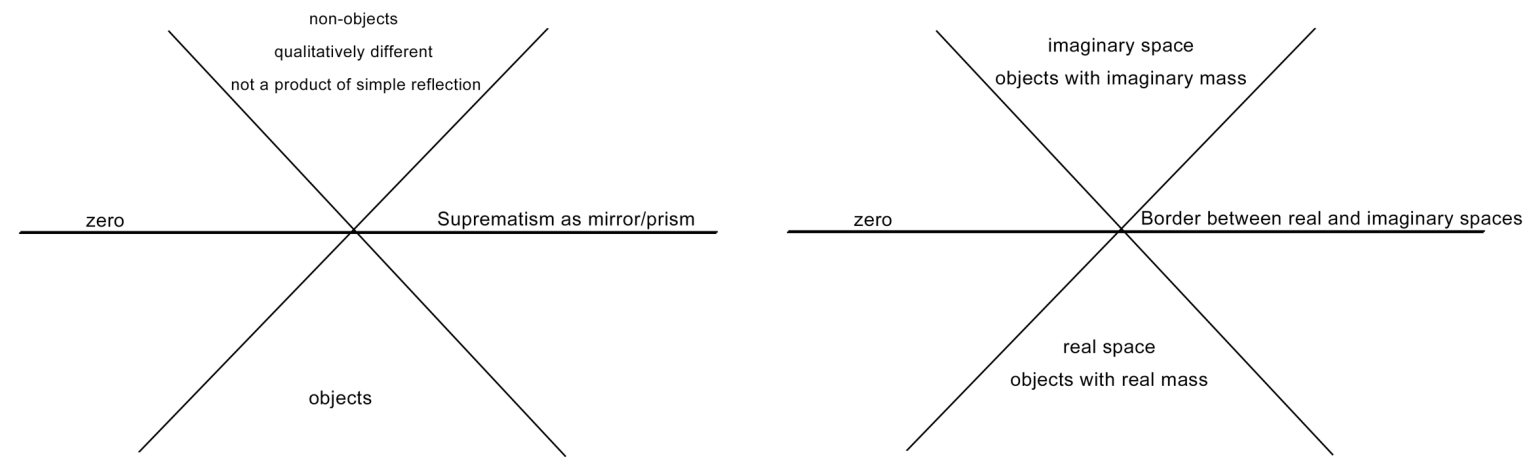

Figure 4.4: Malevich's (right) and Florensky's (left) conceptions of the space(s) (my interpretation). 


\section{Malevich, Florensky, and Mirror Symbolism:}

The parallels between Florensky's and Malevich's envisioning of the beyond can be found in how these thinkers choose to represent this passage. Florensky had closely worked with the graphic artist and woodcut illustrator, Vladimir Favorsky, on the creation of the cover image for Mnimosti $v$ Geometrii. This illustration, according to Florensky who included a clarification to this image at the end of his work on the imaginaries, is an artwork that is infused with mathematical thought. ${ }^{47}$
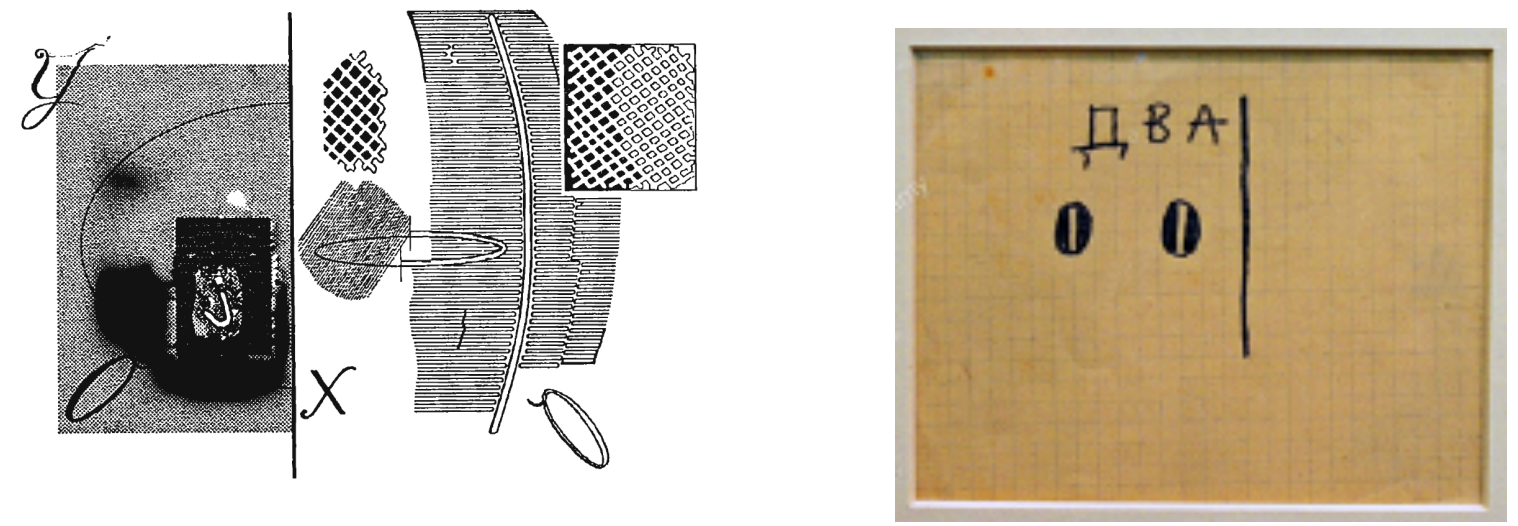

Figure 4.5: Favorsky's cover image for Florensky's Mnimosti v Geometrii (left); Malevich's drawing Two Zeros (1913-1914).

The vertical line that runs across Favorsky's image is the plane that separates the real and the imaginary spaces. Imaginary space is marked using predominantly white colour or the absence thereof. Coincidentally, Malevich deemed white expressive of non-objectivity. In Malevich's Two Zeros (1913-1914), one can notice a comparable arrangement where on the left side of the image the two zeros could be interpreted as representing objective reality (the concept of "two" and "zero" is still objective) that faces the vertical line - the border beyond which is the realm of the no-thing. In a later equation-manifesto Suprematist Mirror (1923), the fundamental 
importance of zero for Malevich is explained: all there is in nature and human consciousness passes through the zero of Suprematism and transforms into non-objectivity.
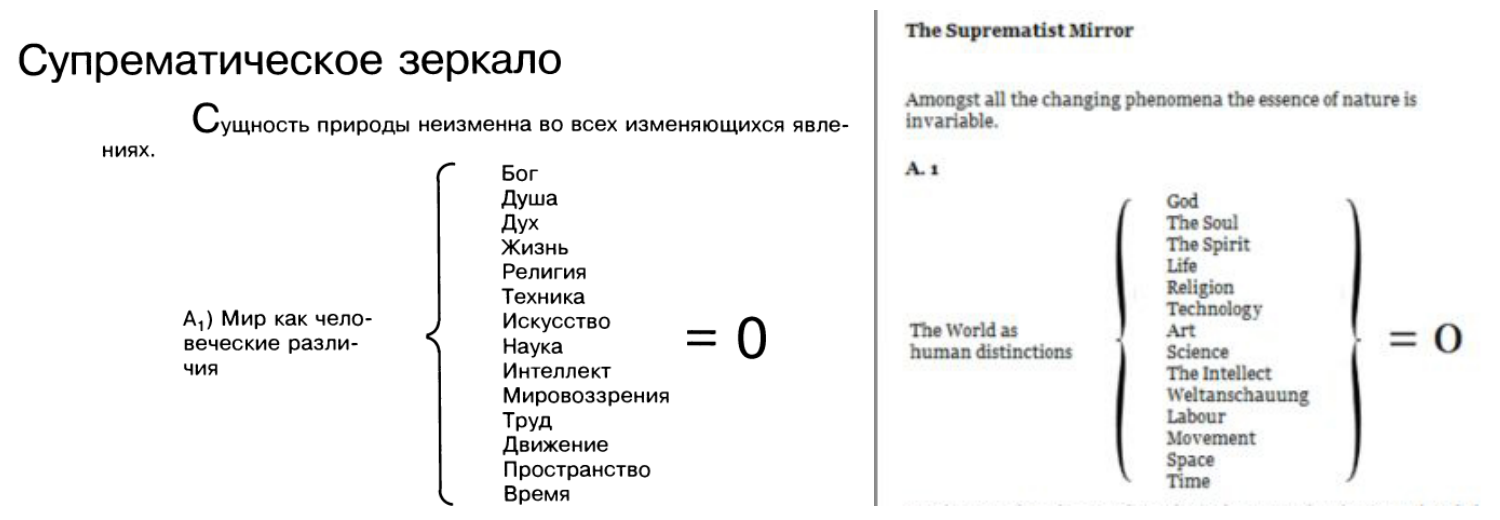

Figure 4.6: Kazimir Malevich, Suprematist Mirror, 1923.

The concept of a mirror resonates with Florensky's theory of imaginary numbers: it brings to mind the reversed side of reality theorized by Florensky. Since a mirror inverts the image (geometrical rotation of coordinates as in Wessel), it assigns imaginary coordinates to the object it depicts, while the surface of the mirror serves as the plane that transforms objects before allowing them to re-appear on the other side, in the underbelly of reality. It can also be understood as a portal to another realm: the mirror is a symbol that signifies distinctive for Russian culture preoccupation with border crossing. ${ }^{48}$ The word that describes the space beyond the surface of the mirror is “зазеркалье” (zazerkal'e). It echoes Bely's adjective “законечный” (zakonechnyj, beyond-end) used to refer to the land beyond zero, and Kruchenykh's neologism “заумный” (zaumnyj, beyond-reason) invented to speak of the new language most appropriate for communication of ideas in the realm beyond the known reality. The artists of the Silver Age in Russia have adopted the symbolism of the mirror as a passage between two worlds. Russian modern and avant-garde artists have continued this tradition, including Marc Chagall and Natalia Goncharova, whose Mirror (1915) and Looking Glass (1912), respectively, are not concerned with reflecting the observed reality. ${ }^{49}$ Similarly, Malevich's mirror equation demonstrates that 
for the artist the mirror does not produce a perfect reflection of an object but instead is akin to a prism that through reverse dispersion collects all the variations of life into one unified beam of non-objectivity:

Также упомянул и о Супрематизме, <отметив,> что через его призму существующие реальности света вообще, или света знания, <не проходят, они> не существуют вовсе. Его призма не преломляет мир явлений ни внутри меня лежащ <ий>, ни вне $<$ меня $>$; $<$ Супрематизмом $>$ не преломляются ни духовные, ни практические явления. Из его абсолютной философии вытекает, что нет ни во мне, ни вне меня вещей, что мир как представление еще не представляет вещи, что и воля моя их не может создать, так <как> нет того, что можно было бы познать и из чего построить познавательные аппараты.

Also mentioned Suprematism, noting that through its prism the existing realities of light in general, or the light of knowledge, do not pass, they do not exist at all. Its prism does not refract the world of phenomena that lies within me, neither that which lies outside me; Suprematism does not refract either spiritual or practical phenomena. From its absolute philosophy it follows that there are no things in me or outside me, that the world as representation does not yet represent a thing, that my will cannot create them either because there is nothing that can be known and nothing from which to build apparatuses that can assist with acquiring knowledge. ${ }^{50}$

\section{Conclusions:}

Malevich agrees with Florensky that beyond the border of the phenomenal world objects cease to exist in their recognizable form. Suprematism, the prism that transforms all into no-thing, opens a passage to reality, whose conditions begin to remind Florensky’s imaginary space, so reminiscent of contemporary physics' concept of a tachyon, or field with imaginary mass. As with other cultural figures discussed in this dissertation, the ideas proposed by Florensky and Malevich seemed radical, preposterous, and daring to their contemporaries, which didn't stop these truly avant-garde thinkers from developing their interdisciplinary philosophies of space. Driven by a utopian belief in the possibilities of science, both Florensky and Malevich envisioned the reality beyond zero, the imaginary and non-objective, and were eager to experience these new conditions of existence. Since technology could not afford such travels, both thinkers engaged in thought experiments, in which the analogy between the order of the cosmos and the order of the mind takes central stage. This Neoplatonic epistemological quest 
mentioned in the chapter on Malevich and Infinity guides Malevich in his aspirations to grasp the order of the universe - an aspiration that to a large degree motivated the development of Suprematism. In one of the passages particularly representative of the mind order / cosmic order analogy, Malevich offers his thoughts on what appears to be a version of Aristotelian-PtolemaicDantean worldview Florensky proposed to revive:

Череп человека представляет собой ту же бесконечность для движения представлений. Он равен бесконечности Вселенной, также не имеет ни потолка, ни пола, бесконечное множество вмещает в себя проектов, изображающих точки как звезды в пространстве. Все так же в нем возникают и исчезают кометы за кометой, эпоха за эпохой совершенств все идут и идут в представлениях человеческого черепа. Какие бы ни были величины, все вмещаются в черепе, все одинаковы - как во Вселенной, так и в нем, а между тем пространство черепа ограничено костной стеной.

Что же тогда пространство, и величина, и вес, когда в маленькой коробке всё вмещается? Это еще больше удивительно, чем Вселенная, которая не ограничена костяной стеной.

Может быть, и она уподобляется человеческому черепу, не ощущает преград в своем черепе для движения планет, как и человек не знает конечности своего черепа и вмещает в него бесконечность; без конца несутся в обоих метеоры солнц, планет и комет.

Всё это происходит потому, что всё суть представления и суждения, ничто не имеет ни веса, ни движения. Таково всё космическое, таково всё в человеке. Как там, так и в человеке ничего нельзя ни разделить, ни соединить, ибо всё представления и всё суждения, целое мое везде и нигде.

The human skull is the same infinity for the movement of representations. It is equal to the infinity of the universe, it also has no ceiling, no floor, it contains an infinite set of projects, which represent points like stars in space. All the same in it, comets are emerging and disappearing one after another, an epoch after epoch of perfection all go and go in the representations of the human skull. Whatever were the values, all fit in the skull, all the same- - both in the universe and in it, and yet the space of the skull is limited by the wall of a bone.

What then is the space, the size, and the weight, when everything is fit in the small box? This is even more surprising than the universe, which is not limited by the bone wall.

Maybe, it is likened to the human skull, does not feel any obstacles in its skull for the motion of the planets, just as a man does not know the finiteness of his skull and accommodates infinity in him; the meteors of the suns, planets and comets are carried without end.

All this happens because all in essence is representation and judgment, nothing has neither weight nor movement. This is all cosmic, this is all human. As there, so in man, nothing can be divided or joined, for all is ideas and all is judgments, my whole is everywhere and nowhere. ${ }^{51}$

Malevich contemplates the possibility that the universe is finite, as is the human brain surrounded by the thick bone of the skull. Similarly to the limitless space of the human mind, which is nonetheless physically associated with the bounded space of the brain, our universe, filled with infinity of stars, may have limits as well. These suggestions point more decisively in the direction of Florensky's groundbreaking theory of the imaginary numbers - the prelude to his large body of work on the Aristotelian-Ptolemaic-Dantean model of the cosmos, which Malevich 
appears to refer to when writing of the finite nature of the universe. Taking into account the other common threads discussed in the chapter - the dual vision of reality, where the real and imaginary (or real and non-objective) realities are separated by a tangible barrier of zero of form represented as a mirror - the intellectual affinities between Florensky's theories of the imaginary space and Malevich's Suprematism become too striking to be ignored. 
${ }^{1}$ Robert Tubbs, What Is a Number?: Mathematical Concepts and Their Origins (Baltimore: Johns Hopkins University Press, 2009), 192.

${ }^{2}$ Ibid., 4.

${ }^{3}$ Ibid., 192.

${ }^{4}$ Paul J. Nahin, An Imaginary Tale: The Story of $\sqrt{ }-1$ (Princeton, NJ: Princeton University Press, 2016), 17.

${ }^{5}$ Robert Tubbs, What Is a Number?: Mathematical Concepts and Their Origins, 192.

${ }^{6}$ Ibid., 198.

${ }^{7}$ Paul J. Nahin, An Imaginary Tale: The Story of $\sqrt{ }-1,48$.

${ }^{8}$ Ibid., 82.

${ }^{9}$ Robert Tubbs, What Is a Number?: Mathematical Concepts and Their Origins, 201.

${ }^{10}$ Paul J. Nahin, An Imaginary Tale: The Story of $\sqrt{ }-1,49$.

${ }^{11}$ Ibid., 49-53.

${ }^{12}$ Pavel Florensky, Mnimosti v Geometrii (Imaginaries in Geometry) (Moscow: Lazur', 1991), 52.

${ }^{13}$ Ibid., 9.

${ }^{14}$ Ibid., 11.

${ }^{15}$ Ibid., 11-12.

${ }^{16}$ Ibid., 15.

${ }^{17}$ Ibid., 25.

${ }^{18}$ Ibid., 25-26 (translation mine).

${ }^{19}$ As quoted in Nikolai Firtich, "Rejecting 'The Sun of Cheap Appearances': Journey Beyond 'Zero' with Kručenych, Malevič, Belyj, Jakobson and Jean-Luc Godard," Russian Literature 65, no. 1-3 (2009): 356. Note: translation by Firtich, except “я вышел в обратную сторону Татлину," which I translated as "I came out on the reverse side of Tatlin." Firtich's translation "to the opposite side" in Russian would sound more like "в противоположную сторону" and does not reflect the meaning of the phrase, obscuring what I contend is a reference to Florensky's theory of imaginary numbers. 
${ }^{20}$ Kazimir Malevich, "Suprematism. From 'The Catalog of the Tenth State Exhibition. Nonobjective Creation and Suprematism," in Sobranie sochinenii v piati tomakh [Collected Works in Five Volumes] (Moscow: Gileia, 1995-2004), vol.1, 151 (translation mine).

${ }^{21}$ Pavel Florensky, Mnimosti v Geometrii (Imaginaries in Geometry), 27.

${ }^{22}$ Ibid, 33-34 (translation mine).

${ }^{23}$ Ibid., 5.

${ }^{24}$ Ibid., 44.

${ }^{25}$ Ibid.

${ }^{26}$ Ibid., 44-45.

${ }^{27}$ Florensky wrongfully attributes this passage to Inferno's Canto XXIII. In fact, it belongs to Canto XXXIV, lines 73 to 94. I quote from Dante Alighieri, The Divine Comedy, trans. Burton Raffel (Evanston, Illinois: Northwestern University Press, 2010), 171-172.

${ }^{28}$ Ibid., 46.

${ }^{29}$ See Kyle Casteel, “Cosmic Shape and Size,” Astronomy (Apr. 2012): 51.

${ }^{30}$ Kazimir Malevich, "Questions” [1916-1918], in Sobranie sochinenii v piati tomakh [Collected Works in Five Volumes] (Moscow: Gileia, 1995-2004), vol. 5, 66 (translation mine).

${ }^{31}$ Ibid., 71 (translation mine).

${ }^{32}$ Kazimir Malevich, "Suprematism. From 'The Catalog of the Tenth State Exhibition. Nonobjective Creation and Suprematism," in Sobranie sochinenii v piati tomakh [Collected Works in Five Volumes] (Moscow: Gileia, 1995-2004), vol. 1, 151 (translation mine).

${ }^{33}$ Nikolai Firtich, "Rejecting 'The Sun of Cheap Appearances': Journey Beyond 'Zero' with Kručenych, Malevič, Belyj, Jakobson and Jean-Luc Godard,” Russian Literature 65, no. 1-3 (2009): 360.

${ }^{34}$ As quoted in Nikolai Firtich, "Rejecting 'The Sun of Cheap Appearances': Journey Beyond 'Zero' with Kručenych, Malevič, Belyj, Jakobson and Jean-Luc Godard,” 362. Note: translation by Firtich, except the word “законечный," which in Firtich's translation "post-terminal" loses its connection with Kruchenykh's word “заумный”, both words have the prefix "za" which can be translated as "beyond": Bely's neologism "законечный” can be roughly translated as beyondend and Kruchenykh's заумный—as beyond-reason.)

35 Ibid., 359. 
${ }^{36}$ Ibid., 357.

${ }^{37}$ Aleksei Kruchenykh and Mikhail Matyushin, Pobeda Nad Solnzem (Victory Over the Sun) (Sankt-Peterburg: Tipografiya Tov-va "Svet", 1913), 17 (translation mine).

38 Ibid., 19.

${ }^{39}$ Ibid.

${ }^{40}$ Charlotte Douglas, Swans of Other Worlds: Kazimir Malevich and the Origins of Abstraction in Russia (Ann Arbor Michigan: UMI Research Press, 1980), 44.

${ }^{41}$ Pavel Florensky, Mnimosti v Geometrii (Imaginaries in Geometry), 49.

${ }^{42}$ Kazimir Malevich, "The Answer to the Two Socialists" [1918-1919], in Sobranie sochinenii v piati tomakh [Collected Works in Five Volumes] (Moscow: Gileia, 1995-2004), vol. 5, 115 (translation mine).

${ }^{43}$ Pavel Florensky, Mnimosti v Geometrii (Imaginaries in Geometry), 50.

${ }^{44}$ Aleksei Kruchenykh and Mikhail Matyushin, Pobeda Nad Solnzem (Victory Over the Sun), 17-18 (translation mine).

${ }^{45}$ Pavel Florensky, Mnimosti v Geometrii (Imaginaries in Geometry), 51.

${ }^{46}$ Kazimir Malevich, "From Cubism to Suprematism" [1915], in Sobranie sochinenii v piati tomakh [Collected Works in Five Volumes] (Moscow: Gileia, 1995-2004), vol. 1, 34 (translation mine).

${ }^{47}$ Pavel Florensky, Mnimosti v Geometrii (Imaginaries in Geometry), 59.

48 Julia Chadaga, "No Mere Reflection: Mirrors as Windows on Russian Culture," Studies in 20th \& 21st Century Literature 34, no. 2 (2010): 171.

${ }^{49}$ Helena Goscilo, "The Mirror in Art: Vanitas, Veritas, and Vision," Studies in 20th \& 21st Century Literature 34, no. 2 (2010): 302-303.

${ }^{50}$ Kazimir Malevich, "Light and Colour," in Sobranie sochinenii v piati tomakh [Collected Works in Five Volumes] (Moscow: Gileia, 1995-2004), vol. 4, 252 (translation mine).

${ }^{51}$ Kazimir Malevich, "Suprematism as Non-Objectivity" [1922], in Sobranie sochinenii v piati tomakh [Collected Works in Five Volumes] (Moscow: Gileia, 1995-2004), vol. 3, 222 (translation mine). 


\section{Chapter 5: Malevich and Cosmism}

\section{Introduction:}

Fin-de-siècle Russia was marked by a proliferation of utopian ideas. Contrary to common belief, it was not only the socialist awakening that shook all the substrates of society-the utopian impulse expressed itself in conservative, reactionary, Slavophile, monarchist, and Christian promises of an earthly paradise. ${ }^{1}$ The longing for a new order gained momentum after 1917 , with the introduction of the capitalist-oriented New Economic Policy (NEP) that sufficiently increased capital gain and instilled a belief in the coming of a better future, taking the form of secular millenarianism. In these years of chronic optimism, utopian faith in technological progress often found expression in mystical and occult ideas, forming intertwined systems of thought.

\section{Malevich and Feodorov:}

The rhetoric of liberation so fundamental for sustaining utopian aspirations, combined with the belief in an inevitable evolution of human species, served as the ideological foundations for Russian Cosmism - one of the most enigmatic philosophical systems that gained unprecedented support in post-revolutionary Russia. Among the most remarkably astonishing proponents of Cosmism was Nikolai Feodorov, whose Philosophy of the Common Task (published posthumously in 1904) inspired such important cultural figures as Dostoevsky, Tolstoy and Gor'kii. ${ }^{2}$ Even though Feodorov's project dated back to Imperial Russia, it was well accepted by the revolutionary elite as its belief in the importance of harnessing nature for the purposes of society corresponded with the communist agenda. ${ }^{3}$ For Feodorov, the reality of evil is an outcome of the blind forces of nature. Eliminating evil requires fighting against accidental, blind chaos, making the world into a rational and creatively regulated universal organism. ${ }^{4}$ Feodorov's 
quest against entropy is best explicated in his conviction in the possibility of overcoming death"the common task" that all the countries in the world, distracted by pointless wars with each other, must, at once, devote their full attention to. ${ }^{5}$

Feodorov emphasized the intimate connections between Earth and the rest of our universe, concluding that the "regulation of nature" on Earth must be complemented by the regulation of the cosmos. ${ }^{6}$ In all human beings, he noticed the deep-seated aspiration to leave the confines of earthly bustling for the depth of the sky. More importantly, the conquering of the cosmos was to become imperative when Feodorov's "common task" of eliminating the necessity of death came to fruition-Earth would simply become unable to sustain all of the immortal lives, including those resurrected, demanding an expansion into space as an escape from an overpopulated, resource-lacking Earth. ${ }^{7}$

Malevich and Tsiolkovsky:

If Feodorov's ideas weren't centered on the practical aspects of space flight, Konstantin Tsiolkovsky's offered constructive suggestions on how to escape the orbit of Earth, providing the scientific grounds for the dream of the cosmos to become the promise of reality. In the 1890s, Tsiolkovsky wrote two science fiction novels in which he introduced designs that would become implemented in late-twentieth-century space exploration e.g. space stations, multistage rockets, space-suits, life-support systems, and spacecraft takeoff and landing methods. ${ }^{8}$ In 1903 , Tsiolkovsky published the first part of the two-part article, "Investigation of Cosmic Spaces by Reactive Devices," explaining the principles of rocketry based on an elegant mathematical model that the inventor developed. ${ }^{9}$ However, it weren't the publications in journals that brought Tsiolkovsky's ideas to prominence and popularity—-the scientist didn't have any formal training and was ostracized from all major academic institutions - it was an alternative network of 
science enthusiasts that helped to do so. Besides being a member of various scientific societies, Tsiolkovsky self-published his works and included a list of contacts of all interested parties to stimulate dialogue through letters. Many of these "scientific letters" were written by individuals without any formal education, who, nonetheless, intelligently shared their speculations on the matter of space flight. ${ }^{10}$

Interestingly, it wasn't only the exploration of space that was the topic of discussion between Tsiolkovsky and his followers. In fact, only about one-eighth of all the books written by Tsiolkovsky were on space research, and one-fourth on dirigible and airship design. ${ }^{11}$ Most of Tsiolkovsky's writings were devoted to expounding on the ideas of Cosmism, which revolve around human immortality, stemming from Tsiolkovsky's acceptance of the principles of panpsychism. ${ }^{12}$ The latter, in Tsiolkovsky's interpretation, is a conviction that all in the universe is alive and possesses the ability to sense, which varies depending on the complexity of the organism. Every sensitive being, according to this doctrine, is made up of individual particles, which Tsiolkovsky terms "atom-spirits." The lives of these beings are akin to dreams. Death disassembles beings into individual immortal atoms incapable of perceiving the movement of time and, therefore, of dreaming. Eventually, after years of reincarnation in a variety of forms of matter, atoms reassemble in a sensitive organism, initiating a new "REM cycle." Belief in progress convinced Tsiolkovsky that the future lives of our atom-spirits would be more gratifying than any state in which we now are able to afford. Thus, the life of atom-spirits, an endless collection of "dreams," exponentially becomes filled with more joy and happiness. Tsiolkovsky states: "Death ends all the suffering and gives, subjectively, immediate happiness." ${ }^{13}$ If Tsiolkovsky's understanding of death and immortality differs from that of Feodorov, his thoughts on the results of the inevitable evolution of the human species into 
"supermen" are alike: the unification of all humans and the end of wars will stimulate a revolution in social consciousness, a total regulation of natural resources, and a growth of the human population, making imperative the colonization of the cosmos. ${ }^{14}$

It is difficult to overestimate the degree of fascination with space that overtook Soviet Russia in the 1920s. With more than two hundred popular science articles and thirty three books written on the topic, ever-growing demand for science fiction novels, and a release of the first Soviet science fiction film Aelita, it could be said that the cultural wave of the space fad had engulfed the totality of Russian culture. ${ }^{15}$ Among the artists most influenced by the promise of human expansion into space certainly was Kazimir Malevich, whose Suprematism synthesizes the scientific and the occult flavors of Feodorov and Tsiolkovsky's philosophies with utmost originality and conviction.

Malevich's utopia is expressed in the artist's belief in the inevitable evolution of consciousness and the coming of the "new man" able to transcend reality and comprehend the hidden universe. In his extensive writings, as if quoting from Feodorov's Philosophy of the Common Task, Malevich states: "The old world has laid its burden on the tithe of the cemetery. In the new world it's too cramped on earth, we are flying into space, digging new passages into its elastic body, and the eagles are in the lowlands of our perfection." 16 The artist has also agreed with the tenets of Feodorov's active evolution: "I shall make my whole state comfortable and convenient, and what is more, I shall convert other states and eventually the whole globe to my comfort and convenience." 17

Malevich's project of the regulation of nature and of the totality of human life had to begin with the development of a new artistic language appropriate for the era of technological advancements of the time. He noticed the incongruity between the intellectual demands of 
current technologies and the lagging of the cultural response prompted by the bureaucracy of habit: "Their bodies are flying on airplanes, but art and life are covered in the old robes of Nerons and Titians." ${ }^{18}$ Malevich's Suprematism - the non-objective language the artist developed - was to free artists from their habitual way of perceiving nature, stimulating the evolution of consciousness necessary for the development of the new man. Radical annihilation of traditional artistic forms resulted in the "birth" of Malevich's "royal infant," Black Square, the zero form from which the language of Suprematism evolved into its maturity.

Malevich's Suprematist shapes are living forms; his paintings_entire living systems. In the 1920s, Suprematism evolved from a single "cell" of Black Square into a complexity and variety of forms, ready to leave the experimental grounds of Malevich's studio-lab and enter the concrete world. ${ }^{19}$ One of the expressions of the new Suprematist world is a prototype of a living flying device that Malevich calls a "technological organism." The artist describes a Suprematist apparatus built as a unitary organism and capable of propelling itself through space by borrowing the electromagnetic energy of the universe, with which it is in a perfect state of symbiosis. ${ }^{20} \mathrm{~A}$ series of Suprematist apparatuses is to form a chain of sputniks orbiting Earth and shaping paths to nearby planets. Malevich explains:

\begin{abstract}
Analyzing suprematist form in motion, we come to a conclusion that linear movement towards any planet cannot be conquered in any other way but through annular movement of intermediate suprematist sputniks, which form a straight line of rings from one sputnik to the other. ... All technical organisms are nothing but little sputniks - entire living worlds ready to fly away into space and occupy a special place. In reality, every one of these sputniks is equipped with a mind and is ready to live its own private life. ...Suprematist forms, as abstraction, have become utilitarian perfection. They do not touch Earth anymore; they can be examined and studied as any other planet or an entire system. I am not talking about a loss of connection with Earth, in the sense of abandonment; I am only pointing at the construction of prototypes of technical organisms of the future suprematist world, conditioned by purely utilitarian necessity. ${ }^{21}$
\end{abstract}

In this lengthy but telling quote one can find a reflection of the peculiar flavor of the Russian approach to the science of space travel: Malevich offers conclusions based on scientific analysis that are at the same time richly infused with panpsychist and vitalist beliefs. Curiously, 
Malevich's sputniks sound a lot like a precursor to the science fiction idea of bioships developed in the 1950s.

Anticipating the near future of interplanetary travel, Malevich directed the attention of his students and later, his own creative energies to the development of architectural designs most appropriate for the new era. Experimentation with architecture began in 1920, the same year Malevich documented his ideas on space travel mentioned earlier. At the time the artist was the director of UNOVIS (abbr. for The Champions of the New Art) where under his directive his then Suprematist colleague, El Lissitzky, and such students as Vera Ermolaeva, Nikolai Suetin and Ilya Chashnik, were to exercise the tenets of Suprematism in practice. $^{22}$

Malevich's project of establishing the science of art and his conviction that Suprematism is the result of the evolution of artistic form is best exemplified in his 1927 film script titled "Artistic and Scientific Film-Painting and Architectural Concerns_-Approaching the New Plastic Architectural System." There the artist traces the development of "the royal infant," his Black Square, into an architecton, which visually comprises a "centripetal accumulation of cubes and parallelepipeds of various sizes and dimensions." ${ }^{23}$ Architectons and planits lack any windows or doors, denying the viewer's access to the interior - $\mathrm{a}$ feature for which Malevich nicknamed his designs "blind suprematist structures." 24 This architectural blindness can also be interpreted as an instance of the artist's philosophical commitment to overcoming objective vision.

As if in response to Velimir Khlebnikov's criticism of contemporary cityscapes observed from the bird's-eye view, which according to the poet remind of nothing but "a scrub brush," 25 Malevich envisioned Suprematist architecture as a system that emphasizes the elegant layout of the buildings" roofs, which for the "winged citizens of the future" 26 will serve as their primary 
habitat. The modularity of the designs suggests the liveliness of the forms - architecture of technological organisms is capable of infinite number of permutations.

With the exception of Lissitzky and Chashnik's extraterrestrial dwelling designs, most of the Suprematist department of UNOVIS had become concerned with refashioning the architecture of Earth. However, Malevich, in the period from 1923 to 1926, produced around two dozen space dwelling designs. Unfortunately, only a handful of these works have survived, among which are Future Planits for Earthlings (1923-1924) and Future Planits for Leningrad:

The Pilot's House (1924). Titles of Malevich's designs suggest a new cosmic view on human life. "Planit" is a neologism, which according to most art historians stems from the word "план" or “планета" ("plan" or "planet") but could also be rooted in the word "планер" (“glider"). If all the aforementioned meanings are combined, "planit" can be translated as an "interplanetary aerodynamic habitat." Malevich writes:

The keys of suprematism are taking me to the discovery of something not yet perceived. My new painting ${ }^{1}$ doesn't belong exclusively to earth. Earth is discarded like a house eaten by wood-boring beetles. And, actually, in the human being and in his consciousness there is a hankering for space, attraction towards "an escape from the globe of Earth."

\section{Conclusion:}

An attraction towards the depths of the universe that Feodorov, Tsiolkovsky and Malevich believed was common to all citizens of Earth continues to drive human expansion into space. Taking into account the perceived presence of the legacy of the Russian avant-garde in contemporary architecture, it is rather possible that the first space dwellings will resemble Malevich's planits and architectons, realizing his utopian ideals. After all, as Tsiolkovsky has famously said: "First, inevitably, the idea, the fantasy, the fairy tale. Then, scientific calculation. Ultimately, fulfillment crowns the dream."28

\footnotetext{
${ }^{1}$ Here, the Russian word is "zivopis," which literally means, "painting that is alive," and it is in this vitalist meaning of the term that Malevich is using this rather traditional word.
} 
${ }^{1}$ Richard Stites, Revolutionary Dreams: Utopian Vision and Experimental Life in the Russian Revolution (New York: Oxford University Press, 1989), 13.

${ }^{2}$ Nikolaŭ Fedorovich Fedorov and S. G. Semenova, Sochineniīa (Moskva: Mysl', 1982), 4.

${ }^{3}$ Ibid.

${ }^{4}$ Ibid., 521.

${ }^{5}$ Ibid., 313, 365-366, 421.

${ }^{6}$ Ibid., 527.

${ }^{7}$ Nikolaŭ Fedorovich Fedorov, Filosofîia obshchago diela: stat'i, mysli i pi'sma (Viernyŭ: Tip. Semiriechenskago obl. pravleniia, 1913), vol. 2, 253.

${ }^{8}$ Asif A. Siddiqi, The Red Rockets' Glare: Spaceflight and the Soviet Imagination, 1857-1957 (Cambridge, MA: Cambridge University Press, 2013), 22.

${ }^{9}$ Konstantin Tsiolkovsky, "Issledovanie mirovyh prostranstv reaktivnymi priborami," Nauchnoe Obozrenie, no. 5 (May 31, 1903).

${ }^{10}$ Asif A. Siddiqi, The Red Rockets' Glare: Spaceflight and the Soviet Imagination, 1857-1957, 48. Also, see the readers' letters written to Tsiolkovsky in K. Tsiolkovsky, Kosmicheskaia filosofiia (Moskva: Sfera, 2004), 59-84.

${ }^{11}$ Asif A. Siddiqi, The Red Rockets' Glare: Spaceflight and the Soviet Imagination, 1857-1957, 53.

${ }^{12}$ K. Tsiolkovsky, "The Monism of the Universe" [1926], in Kosmicheskaia filosofiia (Moskva: Sfera, 2004), 32 (translation mine).

13 Ibid., 52.

14 Ibid., 43.

15 Asif A. Siddiqi, The Red Rockets' Glare: Spaceflight and the Soviet Imagination, 1857-1957, $75 \& 88$.

${ }^{16}$ Kazimir Malevich, "I arrived" [1918], in Sobranie sochinenii v piati tomakh [Collected Works in Five Volumes] (Moscow: Gileia, 1995-2004), vol. 1, 108 (translation mine).

${ }^{17}$ As quoted in Asif A. Siddiqi, The Red Rockets' Glare: Spaceflight and the Soviet Imagination, 1857-1957, 104. 
${ }^{18}$ Kazimir Malevich, "From Cubism and Futurism to Suprematism" [1915], in Sobranie sochinenii v piati tomakh [Collected Works in Five Volumes] (Moscow: Gileia, 1995-2004), vol. 1,37 (translation mine).

${ }^{19}$ Kazimir Malevich, "Suprematism. 34 Drawings" [1920], in Sobranie sochinenii v piati tomakh [Collected Works in Five Volumes] (Moscow: Gileia, 1995-2004, vol. 1, 185 (translation mine).

${ }^{20}$ Ibid., 186.

${ }^{21}$ Ibid.

${ }^{22}$ Maria Gough, "Architecture as Such," in Malevich, ed. Achim Borchardt-Hume (London: Tate Modern, 2015), 158.

${ }^{23}$ Kazimir Malevich, "Artistic and Scientific Film—Painting and Architectural ConcernsApproaching the New Plastic Architectural System" [1927], in Sobranie sochinenii v piati tomakh [Collected Works in Five Volumes] (Moscow: Gileia, 1995-2004), vol. 5, 309-312.

${ }^{24}$ Kazimir Malevich, "Letter from Malevich to El Lissitzky, 14 August 1924, Nemchinovo," in Malevich o Sebe, Sovremenniki o Maleviche: Pis'ma, Dokumenty, Vospominaniia, Kritika: V 2kh Tomakh, eds. I. A. Vakar and T. N. Mikhienko (Moskva: RA, 2004), vol. 1, 160.

${ }^{25}$ Velimir Khlebnikov et al., "Us and Buildings" [1915], in Tvoreniia (Moskva: Sov. pisatel', 1986), 595 (translation mine).

${ }^{26}$ Ibid.

${ }^{27}$ Kazimir Malevich, "Letter from Malevich to M. Matyushin, prior to 23 June 1916, Kunzevo," in Malevich o Sebe, Sovremenniki o Maleviche: Pis'ma, Dokumenty, Vospominaniia, Kritika: V 2-kh Tomakh, eds. I. A. Vakar and T. N. Mikhienko (Moskva: RA, 2004), vol. 1, 89.

${ }^{28}$ Tom D. Crouch, Aiming for the Stars: The Dreamers and Doers of the Space Age (Washington: Smithsonian Institution Scholarly Press, 1999), 30. 


\section{Chapter 6: Malevich and Energy}

Introduction:

In Gutenberg Galaxy: Making of Typographic Man, Marshall McLuhan states that "reorganization of imaginative life" driven by a change in dominant technology is "always delayed by the persistence of older patterns of perception."' The presence of both thermodynamic and electromagnetic paradigms in Malevich's work - the one concerned with the workings of a closed system and the other with open electric fields_-illustrates McLuhan's point. This chapter's purpose is to demonstrate that Malevich's art and writing are situated on the cusp of changing worldviews, from a mechanical to the electromagnetic understanding of reality. These two conceptions of reality enter Malevich's imagination through the scientific ideas of thermodynamics, which harken back to the mechanical principles of force, and through the science of electromagnetism. The co-existence and intermingling of these ideas in the artist's philosophy create the tension between the mechanical aspects of thermodynamic principles and the infinite electric universe of flux manifested in Malevich's project of freeing energy of objects from their formal confines: the rigid lines of Black Square dissipate in White on White.

The Era of Energy:

In his survey of the history of nineteenth-century science, a German British chemist and historian John Theodore Merz stated that one "of the principal performances of the second half of the nineteenth century has been to find ... the greatest of all exact generalizations - the conception of energy." 2 The new physics of energy replaced the earlier Continental model of action-at-adistance force physics. The informal grouping of "North British" physicists and engineers, which included James Clerk Maxwell, William Thomson (Lord Kelvin), Peter Guthrie Tait (18311901), Balfour Stewart (1828-1887), Fleeming Jenkin (1833-1885) and others, was at the 
forefront of the foundation and promotion of the "science of energy," which encompassed the entirety of physical science. ${ }^{3}$ Maxwell's assistant and biographer, William Garnet described this scientific development in the following way: "A complete account of our knowledge of energy and its transformations would require an exhaustive treatise on every branch of physical science, for natural philosophy is simply the science of energy." ${ }^{\prime 4}$

This monistic view of science where, as a chemist and energeticist Wilhelm Ostwald maintained, "everything that happens in the world is nothing but a change in energy," has come to existence through a series of scientific advancements among which the studies of thermodynamics and electromagnetism have played a major role. Prior to these developments the concept of energy did not bear any reference to physical processes and was mainly used in literary or poetic sense to describe the effects of vigorous expression in speech or writingdefinition derived from an incorrect interpretation of Aristotle's śvé $\rho \gamma \varepsilon l \alpha$ (energeia, activity or operation). ${ }^{6}$ In 1805, British physicist and physican, Thomas Young, used the term "energy" in its modern mechanical sense, to refer to what is now known as actual or kinetic energy - a power of doing work, an ability to move material bodies by transferring kinetic energy. ${ }^{7}$ This mechanical understanding of energy propagated by the action-at-a-distance school of thought was contested by theremodynamic studies of a British scientist, Glasgow-based William Thomson (later Lord Kelvin), who was dissatisfied with the application of Newtonian physics to all natural phenomena. Thomson's 1854 definition of thermodynamics declares that it is the subject of "the relation of heat to forces acting between contiguous parts of bodies, and the relation of heat to electrical agency." ${ }^{8}$ His subsequently developed first law of thermodynamics states that heat is a form of energy, which cannot be created or destroyed, making thermodynamic processes a subject to the principle of conservation of energy. His second law of 
thermodynamics, law of entropy, announces that total entropy of an isolated system can never decrease over time; in spontaneous processes, the process of entropy is irreversible.

Thermodynamic principles (kinetic energy provided by the descent of heat from hot to cold bodies or "mechanical effect") made it possible to create heat engines that convert thermal and chemical energy into mechanical energy or work, harking back to classical mechanics.

A catalytic development in science and technology, one that instigated a paradigmatic shift in worldviews, was the foundation of electromagnetic principles led by British scientists Michael Faraday and James Clerk Maxwell, who demonstrated that electricity and magnetism, and electromagnetism and light are interrelated. ${ }^{9}$ Malevich's writings and art reflect the movement from Newtonian to electromagnetic paradigm. From the closed systems of colour Suprematist works, economical in their aim of conserving energy and most certainly inspired by thermodynamic theories, Malevich moves towards the open objectless works of his monochrome period, where all that remains is liberated energy of electromagnetic universe. Ultimately, this intellectual movement leads the artist to the electric field of his own mind, where his thought is not constricted by the formal demands of objective reality.

Malevich and Thermodynamics:

In her paper, Energetic Abstraction: Ostwald, Bogdanov, and Russian Post-Revolutionary Art, Charlotte Douglas suggests that thermodynamics and its extension into energetics as explicated in the works of Wilhelm Ostwald (1853-1932) and Alexander Bogdanov (1873-1928) can be considered a primary intellectual inspiration and force that stimulated Russian abstract painting in the period between 1918 and $1924 .{ }^{10}$ Wilhelm Ostwald, a Nobel Prize winning scientist and the founder of the discipline of physical chemistry, developed a scientific worldview in which the concept of energy held a central place. Ostwald's occult philosophy, which he termed 
"energetics," was to be applied universally to reforming and betterment of society. Energetics stirred interest among the leading scientists of the time, such as Max Planck and Ludwig Boltzmann, who, nonetheless rejected the theory as insufficiently based in mathematical reasoning. ${ }^{11}$ Thus, ignored by the scientific community, Ostwald's energetics was not included in the annals of the history of science. ${ }^{12}$ One of the factors that must have contributed to energetics' exclusion from history was Ostwald's subsequent engagement with pagan traditions of sun worshipping and use of eugenics for improvement of human genetics..$^{13}$ Occult leanings of Ostwald's theory must have contributed to energetics' popularity in Russia, where Ostwald was well known not only for his work in physical chemistry but also for his less conventional teachings. Attesting to the vogue in Russia for Ostwald's ideas is the sheer number of publications: more than thirty individual titles of Ostwald's works were published in Russia from 1888 to $1913 . .^{14}$

Among the main premises of Ostwald's doctrine was the first law of thermodynamics, the law of the conservation of energy, which motivated Ostwald to promote purposeful use of finite and non-replenishable energy. ${ }^{15}$ Ostwald rejected existence of atoms and matter altogether, despising the opposite view as one that propagates mechanistic understanding of the world. ${ }^{16}$ Explicitly stating his anti-matter predilection, Ostwald writes: "While energy becomes clear and more confirmed as a reality, the claims of matter disappear and matter is left without any rights except those of tradition." ${ }^{17}$ Ostwald's rejection of the existence of matter, whose constructed nature he contrasts with the "thingishness or reality of energy,"18 brings to mind Malevich's energetic non-objectivity of Suprematism, a comparable worldview focused on the energy of painterly masses. Malevich's writings are permeated with energetic symbolism and reflect the artist's adherence to energetics' theory of Ostwald. Malevich subscribes to the thermodynamic 
principle of conservation and transformation of energy and admits that matter is in fact energy, which may take the form of the human body:

Возможны доказательства того, что не существует материи, как и я доказываю всею рукописью, но науки доказывают существование энергии, составляющей то, что называем телом.

Совершенством вселенного миродвижения или Бога можно считать то, что самим человеком обнаружено доказательство того, что ничего не исчезает в ней, только принимает новый вид. Таким образом, исчезновение видимости не указывает, что все исчезло.

There may be evidence that there is no matter, as I am proving with the entirety of my writing, but sciences prove the existence of energy, which constitutes what we call the body.

The perfection of the universal world-movement or of God can be considered the fact that the human beings themselves have discovered evidence that nothing disappears, only takes a new form. Thus, the disappearance of visibility does not indicate that everything has disappeared. ${ }^{19}$

Relying on reasoning that betrays the artist's familiarity with the law of the conservation of energy, Malevich concludes that nothing disappears but transforms into another form, offering an uplifting philosophy of life reminiscent of Tsiolkovsky's panpsychism and theories of immortality discussed in an earlier chapter.

Besides writing on ideas reminiscent of the first law of thermodynamics, Malevich also demonstrates his interest in heat, as a form of energy. The artist meditates on the history of the universe's beginnings and contemplates the origin of all forms of life in heat, formed from the decomposition of matter - unified, indestructible energy. Again, the artist uses his monistic worldview to offer a serene picture of reality where catastrophes have no place since the total matter/energy of the (supposedly) isolated system of the universe remains constant. Malevich writes:

Быть может, материя не знает даже, что такое побудительная причина и что такое цель; быть может, она слепа и несознательна в процессах скопления и распада. Быть может, что от распада материи просто возникло тепло, а из него целая вереница новых видов. Человек считал именно такой акт распадения материи мировой катастрофой, расценивая ее с точки зрения распадения дома, дерева или камня. Однако поскольку в природе зафиксирована неуничтожимость материи, зафиксировано, что в огне и на морозе, в тепле и холоде материя единая и все та же, поэтому следует сделать вывод, 
что в мире нет катастроф, мир во всех процессах сотворения и уничтожения пребывает неизменной материей.

Perhaps matter does not even know what the motive is and what the goal is; perhaps it is blind and unconscious in the processes of accumulation and decay. It is possible that heat simply arose from the decay of matter, and from it - a whole chain of new species. A man considered just such an act of disintegration of matter as a world catastrophe, regarding it from the point of view of disintegration of a house, a tree or a stone. However, since the indestructibility of matter is fixed in nature, it is fixed that there is one matter in fire and frost, in warmth and cold, and therefore it must be concluded that there are no catastrophes in the world, the world remains invariable in all processes of creation and destruction. ${ }^{20}$

At least on one occasion, Malevich suggests that the thermal heat energy should be the fifth dimension of art, alongside the fourth dimension of time (after Malevich rejected the geometric fourth dimension as visually incomprehensible and therefore impractical for communication of ideas/energies he accepted time as the fourth dimension of art), the third dimension of space in sculptural works and the two dimensions of painting. ${ }^{21}$ Malevich writes: "Цветописец $<$ в $>$ стал непосредственно перед голым материалом, из которого ему предстоит создать форму двухмерную или трехмерную (скульптур <а>). ... И убеждаюсь, что четвертая мера должна быть отнесена к<0> времени, как $5<-$ я> мера к \{тепломеру\}" (The colour-painter stood directly in front of the bare material, from which he was to create a two-dimensional or threedimensional form (sculpture).... And I am convinced that the fourth dimension should be related to time, as the 5 th dimension to $\left\{\right.$ heat meter\}). ${ }^{22}$

Douglas suggests that another important thinker that stimulated the development of Malevich's energetics' worldview was Alexander Bogdanov, a Russian philosopher, sociologist, and a science fiction writer, who relied on Ostwald's certitude that thermodynamics guides every aspect of life to found his unifying, all-encompassing organizational theory of tectology. ${ }^{23}$ Bogdanov, even though an activist devoted to the cause of Communist movement, did not agree with Vladimir Lenin on the role of Marxism in proletarian revolution. According to Bogdanov, 
Marx's theories were inadequate for instigating cultural revolution he deemed necessary for the creation of a new society, built on the camaraderie and collaboration between the members of the working class. Bogdanov's transformation of the people through cultural change was opposed to Lenin's acquisition of the culture inherited from the former ruling class. ${ }^{24}$ Placing cultural revolution at the center of the program for building a new society prompted Bogdanov to establish Пролеткульт (Proletkult, a portmanteau of the Russian words "proletarskaya kultura," proletarian culture), an artistic laboratory devoted to outlining a true proletarian approach to science and art and reinventing the two through a creative process. ${ }^{25}$ Under Bogdanov's guidance, Proletkult artists' practice of conscious collectivism was to imbue their work with meaning and relevance. Bogdanov writes: “Прежний художник видел в своём труде выявление своей индивидуальности; новый поймёт и почувствует, что в нём и через него творит великое целое-коллектив” (The former artist saw in his work the identification of his individuality; the new - will understand and feel that in him and through him creates a great whole - the collective). ${ }^{26}$ While Malevich would have agreed that the paramount importance of artistic subjectivity is an atavism of the past that must be overcome, it is difficult to imagine the artist's acceptance of melding his artistic concerns with those of the collective. His "great whole" is not the communist society driven by utilitarian needs of self-sustainment, which Malevich, in a derogatory manner, calls общежитие (obshhezhitie, community housing); his is the freed nothing of non-objectivity, the pure energy of Suprematism.

These philosophical contradictions between Bogdanov's and Malevich’s worldviews did not stop the artist from actively participating in Proletkult's educational activities. At a Proletkult lecture in 1920, Malevich declared: "The new Suprematist conclusion leads to new systems, beyond the tangle of objects, to a purely energetic force of motion." ${ }^{27}$ Douglas states that 
Bogdanov's tectology, which is generally considered to be a precursor of systems theory and an early foundation of cybernetics, demonstrates systems thinking that can also be found in Malevich's theories of art. ${ }^{28}$ Indeed, Malevich's theoretical text bearing the name of "On New Systems in Art" (1919-1922) and his film script titled "Artistic and Scientific Film-Painting and Architectural Concerns-Approaching the New Plastic Architectural System" (1927) attest to Douglas' proposition. Systems thinking so permeated Malevich's consciousness that he developed courses for the students of Vitebsk's Peoples' Art School ${ }^{1}$ that reflected his deeply seated interest in this theme. The titles of the subjects speak for themselves: "Statics: Geometricism of form. The composition of contrasting forms. ... Construction. System. History of the system. System theory." 29 As the director of the Museum of Artistic Culture, Malevich proclaimed the analysis of painted "systems" (i.e. paintings) as the primary goal of the institution. ${ }^{30}$

Bogdanov's systems paradigm is rooted in categorization of all human activity into organizational and dis-organizational, making all human actions, whether they are undertaken in the technological, social, or artistic spheres, a material for organizational experience. Analyzing vast data of human interaction from a variety of fields of knowledge, such as social, biological, and physical sciences, allowed Bogdanov to arrive at a general theory of organization, in which

\footnotetext{
${ }^{1}$ From 1917 to 1922, Vitebsk underwent a cultural renaissance fueled by the enthusiasm of its native Marc Chagall, who established its first artistic academy of higher learning titled People's Art School, and of such prominent visiting artists, as Kazimir Malevich and Lazar Lissitzky (the latter's artistic voice matured in Vitebsk). Vitebsk's Peoples' Art School attracted many talented artists to join its faculty, among whom were Ivan Puni and Mstislav Dobuzhinsky. In Vitebsk, Malevich experienced a period of tremendous productivity, publishing many of his most resolved philosophical treatises on new art forms and serving in the capacity of the leader of the student group Unovis. Besides rich developments in the visual arts, Vitebsk's unique cultural environment stimulated flourishing of theatre and music arts, while serving as a fruitful soil for the intellectual experiments of Mikhail's Bakhtin's philosophical circle. Even though the creative explosion in Vitebsk was short-lived, the enriching effects of this cultural wave on the Russian artistic life were long felt. For further details on this period in the history of Vitebsk, please see Aleksandra Shatskikh's Vitebsk: The Life of Art.
} 
unity between the individuals working together allowed for expediency and efficiency required for the members of the communist society. ${ }^{31}$ Bogdanov notes that the term organization, when, for example, it is applied to organization of production, does not refer to the organization of human actions alone. On the contrary, it involves organizing the "labor acts" of humans and machines, which, in an industrial society, replace some of the actions traditionally undertaken by humans. Organic and machine "labor acts" must be organized into a dynamically functional system that responds to the changes in the qualities of the worker or the machine..$^{32}$ The emphasis on making interactions between humans and machines efficient prompted an invigorated interest in biomechanics - the mechanical approach to understanding biological systems that perfectly suited the project of creating the new Soviet worker.

Another member of Proletkult and the organizer of the Central Institute of Labor, Aleksei Gastev, describes the desired state of human/machine interaction as that where the two have become one organism attuned to expedient production. Gastev, anticipating the contemporary concept of a cyborg, writes: “Мы слились со своими железными товарищами, мы с ними спелись, мы вместе создали новую душу движенья, где работник и станок неразрывны” (We merged with our iron comrades, achieved unity, together we created a new soul of movement, where the worker and the machine are inseparable. $)^{33}$ The law of the conservation of energy dictates economical use of human energy, prompting Gastev to conclude that "тело должно быть воспитано, как рабочая машина. Если вы хотите победить, достичь,тренируйтесь, вырабатывайте выдержку—вы победите, вы достигнете. ... В машинеорудии—всё рассчитано и подогнано. Будем также рассчитывать и живую машину— человека" (the body must be brought up like a working machine. If you want to win, to make achievements - train, develop endurance-you will win, you will make achievements. ... In the 
machine-tool - everything is calculated and fitted. Similarly, we will also calculate the living machine — a human being). ${ }^{34}$ Malevich has adopted economy as one of the primary methods in painting and sculpture. Ornamentation and decorative splurging of the past were based on irresponsible waste of human energy and should be substituted with forms whose creation requires the least amount of energy, while yielding the most expressive dynamic results.

Malevich states:

Но выдвигается еще вопрос — вопрос экономический, который поставит себя, пожалуй, в первоисток всего действа и который скажет, что всякое действо совершается через энергию тела, а всякое тело стремится к сохранности своей энергии, а потому всякое мое действо должно совершаться экономическим путем. Так движется все творчество человека. И его творческая мысль давно уже убегает от путаных, может быть, красивых узорных сплетений и украшений к простому экономическому выражению энергийного действа, так что все сложения такого действа уже слагаются не из эстетического, а из экономического веления. Последние течения в искусствекубизм, футуризм, супрематизм-основаны на этом действе.

But another question is being raised - an economic question, which will put itself, perhaps, in the primary sources of the whole action and which will say that every action is performed through the energy of the body, and every body strives for the preservation of its energy, and therefore every action must be performed economically. So moves all the creativity of human beings. And their creative thought has long since fled from the confused, perhaps beautifully patterned entanglements and ornaments, to the simple economic expression of an energetic action, so that all the additions of such an action are already composed not of aesthetic, but of economic dictation. The latest trends in art—cubism, futurism, suprematism—are based on this action. ${ }^{35}$

While there are parallels between Malevich's call for more efficient artistic expression based on the need of human body to conserve energy, it is far removed from concerns for the productive results of labor that drive Gastev's theories. Malevich did not subscribe to the valorization of labor to which his essay "Laziness as the Actual Truth About Humankind" (1921) attests. In his radical disregard for the prevalence of labor in human life, Malevich approaches Bogdanov's philosophy more than he does Gastev's almost religious glorification of the process of production. One of the goals of Bogdanov's utopian tectological science was to develop selfregulating machinery that would free the working class from manual labor, allowing time for 
creative and intellectual work. ${ }^{36}$ In his "Establishing A in Art" (Установление А в Искусстве),

Malevich, in agreement with Bogdanov, states that it is necessary to "признать труд

пережитком старого мира насилия, так как современность мира стоит на творчестве”

(recognize labour as a relic of the old world of violence, since the modernity of the world stands

on creativity). ${ }^{37}$

In an article “Беглым огнем по Центральному Институту труда” (June $\left.18^{\text {th }}, 1928\right)$,

Sergei Eisenstein, who knew Malevich well, uses Malevich’s artistic process as an example in

support of his disagreement with Gastev's mechanical understanding of human organism:

Занимаясь по иным заданиям и в иной области, чем ЦИТ, вопросами органики движения и раскрытием и усвоением общих законов органического протекания двигательного процесса, общих для всех разновидностей его, я специально обращался с вопросом относительно двигательной стороны процесса владения кистью к одному из наших виднейших и популярнейших за рубежом художнику-К. С. Малевичу. ... По свидетельству этого высоко компетентного мастера-“мазок” его кисти никак не результат движения только кисти его руки-а всей мощи крепко сшитого квадрата его фигуры от плеч до пяток: картину пишешь, говорил он, выражаясь “фигурально”, из самого нутра всей своей сущности, <..> целиком. И демонстрируя мне технику острого мазка по холсту, спружинивался весь от каблука, “включавшего” толчок к мазку.

Being engaged in other tasks and in a different area than CIT [Central Institute of Labour], the issues of organic movement and the discovery and understanding of the general laws of organic flow of the motor process, common to all its varieties, I specifically asked one of our most prominent and popular artist abroad, K. S. Malevich, about the motor side of using a paintbrush. ... According to the testimony of this highly competent master, the "brushstroke" of his brush is in no way the result of moving only the hand of his arm, but of the totality of the tightly stitched square of his figure, from shoulders to heels: you write a picture, he said, "figuratively" speaking, from the very inside of your very essence, $<\ldots>$ in its entirety. And showing me a sharp brushstroke technique on the canvas, all of him sprung from the heel, which "was included" into the push towards the brushstroke. ${ }^{38}$

According to Eisenstein's testimony, Malevich's understanding of movement is far from the mechanical, machine-like definition of Gastev. Malevich paints with the entirety of his body, the movement of which continues in the movement of the paintbrush, which can be construed as prosthesis of the muscles and flesh of the artist's hand. ${ }^{2}$ This organic conceptualization of

\footnotetext{
${ }^{2}$ In fact, this quote from Eisenstein speaks to his and, most probably, to Malevich's familiarity with the organ projection theory developed by Ernst Kapp in the $19^{\text {th }}$ century and further theorized by Pavel Florensky (1920s) and Marshall McLuhan (1960s). Since discussion of this theory requires sufficiently more space than I can afford here, I will have to leave this topic outside of the scope of this chapter and investigate it in my subsequent works.
} 
movement and of technology that continues this movement, in this case a paintbrush, emphasizes interconnectedness, fluidity, and transformation of one form of energy, that of the artist's muscles, into another - the energy of the artwork. Engaging into a creative process in such manner betrays a vision of the world as electromagnetic, taking us into the second part of this chapter.

\section{Malevich and Electromagnetism:}

In his book The Science of Culture and the Phenomenology of Styles ([1991], 2012), Renato Barilli adopts the concept of cultural materialism and Marshall McLuhan's ideas on electrology to bring to light the paramount importance for artistic expression of the theories of electromagnetism, developed by Michael Faraday and James Clerk Maxwell in the second half of the $19^{\text {th }}$ century. According to Barilli, the development of electromagnetic principles has ultimately altered human perception of external data and continues shaping reality in the current age of digital technology. Inspired by McLuhan's Understanding Media (1964), Barilli’s book juxtaposes the art and culture stimulated by the invention of the printing press - the modern period — with the postmodern culture brought about by electrologic revolution, characterized by the widespread application of electromagnetism and electric technology. Quite aware of the fallacies of technological determinism, Barilli emphasizes that technological inventions often are predated by their analogous symbolic realizations. He adopts Lucien Goldmann's notion of homologies to explain the parallel (homologous) developments in the technical and the symbolic levels of culture. Modern period, marked by the invention of the printing press in 1450, was symbolically expressed in Leon Battista Alberti's theorization of perspective in $1435 .{ }^{39}$ Thus, the technology of the printing press was developed fifteen years after the foundational ideas on perspective were put forth. However, both discoveries, being homologous, are characterized by 
linearity, grid-like structure, and aspiration to arrest the flow of life, whether on a rigidly structured page or within an immobile pyramid of visual rays that geometrically constitutes linear perspective. ${ }^{40}$

Similarly, electric technology was invented after electric ideas were realized symbolically. Antonio Pacinotti invented the dynamo in 1860; almost a century after Luigi Galvani's experiments with animal electricity (1780) and Alessandro Volta's invention of the Voltaic pile (1799) saw the light of day. ${ }^{41}$ It is with the ideas of Galvani and Volta, who symbolically introduced electrology, that Barilli associates the onset of the electric age. Homologous breakthroughs in art, according to Barilli, are the works of William Blake and Henri Fuseli. These first electrologic artists have defied the rules of perspective, which dominated the painting technique of the time, and created otherworldly visions of swirly planes reminiscent of electromagnetic waves. ${ }^{42}$

In dialogue with Barilli's book is R. Bruce Elder's volume Cubism and Futurism: Spiritual Machines and the Cinematic Effect (2018), where the author develops an argument that Cubism and, especially, Futurism are artistic movements particularly paradigmatic of the electrologic era. These artists epitomized the original, military meaning of the term "avantgarde"-_advance guard" (tr. from French); a small number of strong army corps that marches ahead to bind and engage an enemy, securing the time and space necessary for the strategic operations of the main army. ${ }^{43}$ Long before McLuhan identified this role of art, Cubist and Futurist artworks functioned as early warning systems, preparing the world for the zenith of an electrotechnic age. ${ }^{44}$ After Fuseli and Blake began pondering the implications of electric ideas for human existence more than a century prior, Cubists and Futurist artists have creatively 
responded to the shift towards a vision of reality as flux instigated by the science of electromagnetism.

Even though Cubism and Futurism have many different faces and include artists belonging to different cultural traditions (i.e. Italian Futurism and Russia Futurism), their works contain certain general characteristics among which are the disregard for linear perspective, inquiry into human perception, striving to express heightened sensation of dynamism and simultaneity of time and space. ${ }^{45}$ Suprematism takes further the experiments of Cubism and Futurism: “Футуризм через вещь вел нас к динамизму живописных масс. Кубизм через разлом вещи ведет к чисто живописной пластике. Оба усилия идут к СУПРЕМАТИИ ЖИВОПИСИ" (Futurism, through the object, led us to the dynamism of the painterly masses. Cubism, through the rift of the object, leads to a purely painterly plastic. Both efforts move towards the SUPREMATISM OF PAINTING). ${ }^{46}$ Since Malevich considered these two movements precursors leading to the development of Suprematism, it, too, shares the aforementioned characteristics. Simultaneity, lack of perspective, and dynamism are manifested in another important technological innovation — aviation. The possibility of flight was so inspiring for Malevich that he claimed it was responsible for the development of Suprematism. In the following pages I will trace the presence of electrologic ${ }^{3}$ ideas in Malevich's oeuvre and zoom in on the role of aviation in the conception of Suprematism by consulting Malevich's important essay "Introduction to the Theory of the Additional Element in Painting." But before delving into these matters, I would like to briefly introduce the historical importance of the technology of electricity for Russia at the time. Taking into account that electrification became a state technology during Malevich's most active years, the intuition that Malevich's art is guided

\footnotetext{
${ }^{3}$ This is actually a neologism coined by my supervisor R. Bruce Elder. It was invented to identify that worldview that was founded on the ideas of Michael Faraday and James Clerk Maxwell.
} 
by an artistic aspiration to comprehend reality as a manifestation of electromagnetic principles becomes ever more tangible.

Malevich and Electrification:

Electric technology played an unprecedented importance for the Russian state before and especially after the revolution of 1917. Even though from 1886 to 1914 electrification in Russia developed slowly compared to the West, the First World War demonstrated the indispensability of this technology for military needs and attracted attention of the state officials to the lack of this invaluable energy source..$^{47}$ In 1920 , the Communist party christened electrification the new state technology. Electrical engineers rose to political power convincing technologically minded Vladimir Lenin to approve GOELRO (State Commission for the Electrification of Russia) - a radical and optimistic plan to create a state network of regional power stations in order to eliminate the split between villages and cities and build communist society. ${ }^{48}$ Lenin's belief in liberation through technology and utopian conviction that this technology is electricity can be witnessed in his famous statement at the $8^{\text {th }}$ Congress of Soviets: "Communism is Soviet power plus electrification of the whole country." ${ }^{49}$ Upon becoming acquainted with Lenin in September 1920, H.G. Wells remarked: "For Lenin, who like a good orthodox Marxist denounces all 'Utopians,' has succumbed at last to a Utopia of the electricians." ${ }^{50}$ In this climate of electrical utopia advertised through every channel of communist propaganda it must have been difficult to stay uninitiated into the science of electromagnetism. Indeed, many Russian artists were fascinated with the subject with some notable examples being Natalia Goncharova's Electric Lamp (1913) and Pavel Filonov's GOELRO (Lenin's Plan for the Electrification of Russia) (1931) and Gustav Klutsis' inventive collages Lenin and Electrification (1925) and Electrification of the Entire Country (1920). This literal engagement with the technological 
manifestation of electromagnetic paradigm, i.e. artistic reflections on Soviet electrification, often went hand-in-hand with experimentation with its symbolic aspects. In case of Kazimir Malevich, the artists rarely created works about electricity, with the exception of such drawings as Suprematist Composition (Sensation of Flowing. Telegraph) (1915), Suprematist Composition (Magnetic Attraction) (1914), and Suprematist Composition (Sensation of Magnetic Attraction) (1914). Instead of being guided by the techno-utopian fascination with the utilitarian applications of electricity, Malevich's art explores its philosophical implications, shifts in perceptions of reality that it created.

Malevich, Apollinaire, and Simultaneity:

Before developing Suprematism in 1915, Malevich experimented with Cubist and Futurist forms, creating such eclectic works as Samovar (1913), which demonstrates influence of both Parisian Cubism and Italian Futurism. ${ }^{51}$ A 1914 painting Englishman in Moscow is particularly striking in its synthesis of Cubist lettering that spells out "partial eclipse," alogism also found in Marinetti, and religious iconography. In this work, one can observe the aforementioned features of electrologic art: the space of the painting expresses the new conditions of simultaneity dictated by the changed technological environment of speed and movement. Even though this work belongs to the alogist period in Malevich's art—it is intended to juxtapose and display incongruent elements that are not to be understood with the faculty of reason-it is difficult to avoid the temptation to interpret this important work.

The first impression from looking at Englishman in Moscow is claustrophobic: the painting is densely populated with overlapping figurative elements, jammed within pictorial space flattened by the lack of perspective. A large portrait of a man, whom the scholar of Russian art John Milner identified as the Futurist painter and writer David Burlyuk, occupies a 
prominent place within the painting. An awareness of the approaching war is expressed in the ready-to-fire bayonets and a large red arrow that cuts across the canvas as if instructing direction of army forces; a sense of loss of spirituality and the need to regain it —in the diminutive image of a church contrasted with the oversized fish symbolic of Christ. In the left top corner, Malevich incorporates a yellow shape of colour that appears to be a source of electric light, a projector that illuminates much more effectively than the candle depicted in the middle of the canvas. It could be that Malevich suggests that the spiritual twilight, the "partial eclipse" instilled by the coming war and the fall of faith expressed in the feeble light of the candle, will be overcome in the new age of electromagnetism.

Interestingly, analogous themes can be witnessed in Guillaume Apollinaire's poem Zone published in 1913, a year before Malevich finished his Englishman in Moscow. A French poet, playwright, and one of the most prominent theorists of Cubism and later Surrealism, Apollinaire belonged to a tradition of poets whose verse was kindled by the dissolution of the old religion and the need to reestablish mythology necessary to bind the people together ${ }^{52}$ This aspiration for cultural renewal was expressed in Apollinaire's recasting of religious myths in his landmark 1913 poem "Zone," in which he describes the regeneration of the world through the efforts of poeticized collective consciousness. The poem is structured around a walk in Paris from one sunrise to another, told through the voice of the author, who deliberately decentralizes his experiences by referring to himself as "I" and as "you." Together with disregard for punctuation and non-linear narration, Apollinaire creates a sense of a collective interconnected consciousness. He relates this focus on collective rather than individual efforts of a lone poet, to the unifying principles originating in the new technology. New (avant-garde) art, born on the cusp of the shift in worldviews from static Newtonian to the dynamic electromagnetic universe, 
will give rise to new spirit and consciousness as an all-encompassing electromagnetic phenomenon, which will rejuvenate the world. ${ }^{53}$ The simultaneous presence of multiple figures and overlapping objects, the all-embracing unifying principle that guides composition, the philosophical conviction that the loss of spirituality can be regained in the new electromagnetic consciousness are qualities that Malevich's Englishman in Moscow shares with Apollinaire's Zone.

\section{Malevich and Disregard for Perspective:}

"Farewell farewell Let the sun beheaded be" are the final lines of Apollinaire's Zone. The violence of sunrise as envisioned by Apollinaire brings to mind the libretto for the Russian Futurist opera Victory over the Sun (1913), whose first act is devoted to portraying the violent capture and imprisonment of the "sun of cheap appearances" responsible for the creation of illusion of reality. Apollinaire, who was well known in Russia at the time,${ }^{54}$ might have inspired Kruchenykh to experiment with poetic form, resulting in the daring verse of the opera's libretto. As it has been discussed earlier, Malevich's working on the set designs for this opera stimulated his "discovery" of Suprematism. However, working on the visual components of the opera was not the only decisive experience that led Malevich to his ultimate discovery. I contend that Kruchenykh's Zaum and, in particular, the near absence of punctuation that this language proposes, must have been a factor in Malevich's embracing art that does not rely on linear perspective.

In Gutenberg Galaxy: The Making of Typographic Man (1962), McLuhan recognizes the lack of punctuation and visual aids "as a carefully devised strategy to get the passive visual reader into participant, oral action." ${ }^{55}$ Free verse allows fluidity and flexibility not constricted by punctuation. Without the assistance of visual aids, the reader is prompted to enact reading aloud, 
akin to ancient or medieval readers. In this way, the passive silent reader becomes an active cocreator of meaning, combining the visual and auditory senses: "vers libre is for the ear as much as for the eye. ${ }^{" 56}$ Since McLuhan considered oral culture representative of the electric era, free verse, with its reliance on oral recitation, is a manifestation of the electric age. Simultaneity of experiences that oral culture allows, indeterminacy and fluidity of free verse are imaginative adaptations to the new (dis)order dictated by the electromagnetic conception of reality. McLuhan states:

Today our science and method strive not towards a point of view but to discover how not to have a point of view, the method not of closure and perspective but of the open 'field' and the suspended judgment. Such is now the only viable method under electric conditions of simultaneous information movement and total human interdependence. ${ }^{57}$

Not to have a point of view by avoiding perspective, to break through the closure of the picture frame and portray an open field - these are artistic motivations of Malevich. The lack of punctuation and lack of perspective, according to McLuhan, are comparable methods to achieve the suspension of judgment and portray the movement of simultaneous information perceived by the electrified collective consciousness. These common aspects of free verse, practiced by Kruchenykh in the libretto for Victory Over the Sun and Malevich in Suprematism, make it apparent that there is a much deeper connection between Zaum poetry and Malevich's work than it was previously ascertained. The oral, electric features of poetic language of Victory Over the Sun's libretto must have contributed to Malevich's development of the visual language of Suprematism that does not rely on linear perspective and seeks to create a sense of visual totality, of oneness and unity—qualities of electric art especially noticeable in the artist's later works, such as White on White (1918).

Barilli, too, identifies linear perspective as belonging to the symbolic order of mechanical age; conversely, the flattening of the image on the picture plane is a feature of electrologic age. 
Perspectival drawing invented by Alberti, gave birth to the idea of a painting as an "open window" into the depicted space. Once, with the advent of electromagnetic ideas, the notion of perception as static, instantaneous and punctiform was revealed as questionable, the concept of painting as a window became refuted and completely abandoned by contemporary (that is electrotechnic) artists. ${ }^{58}$ In this regard, Barilli's and Malevich's statements are curiously alike. Barilli writes: "Alberti, however, is aware that he is placing a straightjacket on artists, restricting their freedom of movement and obliging to be nothing but the eye." ${ }^{99}$ Malevich agrees: "Когда установили законы перспективы, для изобразительного искусства была установлена привязь. Для художника было установлено стойло, в котором он должен был оперировать" (When the laws of perspective were established, a leash was established for the visual arts. For the artist was established a stall in which he was supposed to operate) ${ }^{60}$ And elsewhere: “Законы перспективы, как и анатомии, суть абсурды недомыслов живописца...” (The laws of perspective, like anatomy, are the absurdities of the painter's foolishness ....) ${ }^{61}$ Malevich notes that children and ancient peoples had a more appropriate understanding of perspective that was relative to the circumstances in which the objects were encountered. In emphasizing the wisdom of the ancients, Malevich approaches theories of McLuhan, who highlighted the connection between the oral culture of the tribal peoples and the electric age. ${ }^{62}$ Experiencing the futility of attempts to render objects using linear perspective leads Malevich to conclude that the objects simply do not exist:

Было говорено о перспективе как особом обстоятельстве современного изобразительного Искусства и понимании ее первобытным человеком и детьми, которые, в отличие от современных <людей>, понимали ее, с моей точки зрения, правильнее, они ее понимали по существу, или по обстоятельствам, в которые попадала та или иная вещь или человек. Измерение было ее по обстоятельствам, от которых зависела ее величина. Последним указывалась уже большая научная проблема, которая разрешается и Эйнштейном. Здесь в детских и первобытных изображениях вам $<$ представлено> указание, что границ вещь не имеет, не имеет своей предельности, а следовательно, и реальности, так как она видоизменяется в каждом обстоятельстве. 
It was spoken about perspective as a special circumstance of modern fine Art and its understanding by ancient human beings and children, who, unlike modern "people," understood it, from my point of view, more correctly, they understood it in essence, or in circumstances in which this or that thing or a person fell. Its measurement was related to the circumstances its values depended on. The latter [modern human being] already pointed out an enormous scientific problem, which is resolved by Einstein. Here, in the children's and primeval peoples' images, you are < presented $>$ with an indication that a thing has no borders, does not have its limits, and consequently, it has no reality, as it is modified in each circumstance. $^{63}$

Constantly altered relations between objects forbid depiction of these objects in art since any such attempts would be purely arbitrary. Malevich reasons that the lack of static relation between objects makes it impossible to determine their limits, and what has no limit is not an object. Malevich and Dynamism:

In addition to the theory of relativity mentioned by Malevich in the quote above, the notion that a given object is never static and is subject to constant change was also supported by the developments in the study of human perception, which have revealed that retinal image does not abruptly decay but persists for some time. Elder notes that the Futurists recognized these new findings in the science of perception and were aware that motion is perceived more as a blur, resulting from the overlapping of successive retinal images and representing the trajectory of motion, than as a sequence of clearly defined hard-edged visual imprints. ${ }^{64}$ This understanding granted a fundamentally different conception of reality as dynamic, where everything at all times is in motion. ${ }^{65}$ Malevich, who argued that “динамизм, радио, электричество-есть элементы наших новых ощущений” (dynamism, radio, electricity—-there are elements of our new sensations) ${ }^{66}$ harnessed this inherent dynamism to release form from its prison of objecthood, ultimately arriving at the non-objective Suprematist art. The artist clearly identified universal dynamism as a phenomenon that accompanied the new understanding of reality as electromagnetic, which he manifested in his non-objective painting:

В пояснение скажем, что <если> художество было в каменном веке в образцах камня и в образцах бронзы в бронзовом, мраморном, стеклянном, паровом, то очевидно, что оно будет в электрорадио-магнитной эпохе, обращенной в форму искусств, в образцах динамических, что и в этом случае оно должно иметь новую форму уже чистой культуры. 
To further elaborate, we say that $<$ if $>$ in the Stone Age the art was in stone samples and in bronze samples - in Bronze [Age], marble, glass, steam, then it is obvious that it will be in dynamic samples in the electro-magnetic epoch turned into a form of art, as in this case, it [art] must have a new form of already pure [that is non-objective] culture. ${ }^{67}$

\section{Malevich and Aviation:}

The features of electrologic art that were discussed so far - simultaneity, lack of perspective, and dynamism—-become integrated and manifested in another highly influential for electric art technology developed at the turn of the centuries: aviation. Via the heightened point of view, one could obtain a vision of a unified world, flattened by the unusual perspective and dynamically animated by the aircraft's motion. In Wheel, Bicycle, and Airplane, McLuhan sketches out an organic evolution of the technology of the wheel (it is organic since McLuhan considers all technology being extensions of our physical bodies), which he considers a prime symbol of Cartesian mind. The wheel and road required for its completion are responsible for the centralization of movement and creation of a radiational, center-margin structure. McLuhan associates the effects of this technology on social order with the visual image of an explosion and contrasts these effects to the implosion, contraction, and simultaneity of electric technology, such as an airplane. The latter roams in three-dimensions of space and therefore is non-linear and decentralized. It is an epitome of "simultaneous touch" as "in one spot one could touch every part of the world because of aviation." ${ }^{98}$ It is not surprising that this electric technology of simultaneous touch was so important to Apollinaire, who according to Elder helped make simultaneity a principal theme of the early twentieth century. ${ }^{69}$ Ability to gain a higher vantage point allows witnessing all-at-oneness of seemingly disparate elements and creates an allusion to simultaneous perception of past, present, and future as the planar time reminiscent of Ouspensky's fourth dimension discussed in an earlier chapter. In Zone, Apollinaire writes:

It is God who died on Friday and rose again on Sunday

It is Christ who soars in the sky better than any aviator 
He breaks the world's altitude record

Christ the pupil of the eye

Twentieth pupil of the centuries he knows how

And turned into a bird this century rises in the air like Jesus

The devils in their abysses lift their heads to look at it ${ }^{70}$

This passage, which depicts an implosion and contraction of past and the future, highlights the importance of flight for Apollinaire. For Malevich, conquering the third dimension of spacethat of air - arguably, carried an even more paramount significance. It is with the air that Malevich connects the birth of Suprematism. His 1914 painting Aviator predates Suprematism and its well-developed theories. However, one can find a premonition of the Black Square (1915), the zero of form Malevich would create a year later, in the aviator's cylinder adorned with the number " 0 ," which projects three cones of light, reminiscent of electric projectors. In 1927, when the theory and philosophy of Suprematism was fully developed, Malevich explained that flight and higher vantage point that it allows are the major inspirations for Suprematist artists (see Figure 6.1). ${ }^{71}$
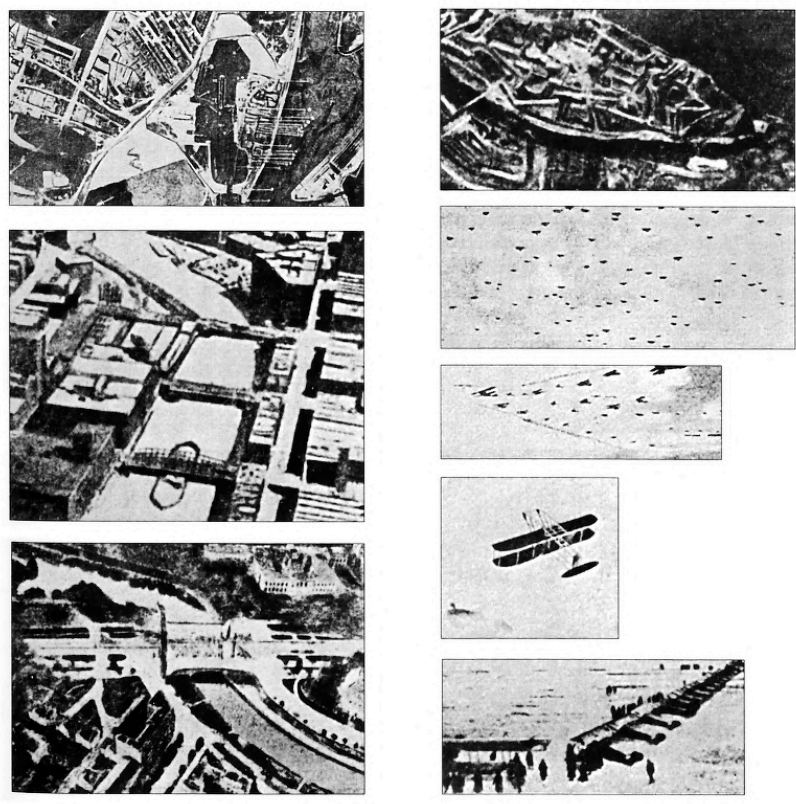

Ил. 28-35. Окружение, вдохновляющее супрематистов ( "действительность")

Figure 6.1: Kazimir Malevich, Environment that inspires suprematists ("reality"), photographs that accompany Malevich's essay "Introduction to the Theory of the Additional Element in Painting” (1923). 


\section{Malevich and Theory of the Additional Element:}

In his essay titled "Introduction to the Theory of the Additional Element in Painting"-an incredibly rich source for understanding Malevich's philosophy and one that I am compelled to revisit often-Malevich studies painterly forms that he treats as "bodies," attempting a rigorous, analytical method in pursuit of an almost scientific precision in his reasoning. Malevich's Science of Artistic Culture is to a large degree inspired by the 1882 Robert Koch's discovery of Mycobacterium tuberculosis, the bacterium that cause tuberculosis, which in Russian is also called “палочка Коха” (Koch bacillus but also Koch rod, Koch stick). Malevich's study emulates that of Koch, the father of modern bacteriology, and focuses on the interaction between painterly bodies (artworks) and new elements that enter inside these bodies via the consciousness of the painter (additional elements). Writing in a manner that betrays Malevich's familiarity with Bogdanov's tectology, the artist describes destabilization of equilibrium in a painting's body and subsequent arrival at a new painterly system, the novelty of which causes shock to societal norms, which, with time, stabilize resulting in the canonization of the new art form. ${ }^{72}$ Concerned with the effects of the surrounding environment on artistic bodies (artworks), Malevich identified "the energetic center" of a provincial town with its parks, hills, and buildings as the environment that spawned Cezanne's artworks. Cubist works are born out of excitation of an artist's nervous system immersed in the environment that borders with the metallic culture of contemporary cities. The additional element of Suprematism, “супрпрямая” (suprprjamaja, suprline, [note the similarity with the bacillus/rod/stick of "палочка Коха"]), or "suprematist additional element of a dynamic order," is a result of interaction with the environment of air-a conclusion that Malevich illustrates in a visual chart titled Environment that inspires suprematists (“reality”) (Окружение, вдохновляющее супрематистов (“действительность”)), a photo collage consisting of photographs of airplanes and aerial shots 
(see Fig. 1). ${ }^{73}$ Malevich pronounces his Suprematism as the appropriate visual language for designing the visual culture of the future. Suprematist line ideally suits this task; it is a visual element that constitutes the dynamism of new electric age manifested in flight. The ordered geometric forms of buildings seen from above, strong lines of airplane wings, and condensation trails formed by aircrafts entered the bodies of paintings as additional elements of "suprline." Suprematism, as a new system of painting, could not have been established in pastoral landscapes of rural Russia-it required the dynamism of cities to form. Malevich writes:

\footnotetext{
Их динамические элементы не могли развиться в провинции, вне металлической культуры, которая ведет свою борьбу со всеми пригородами, глубокими провинциями и архитектурой столиц, ведет борьбу с крестьянским искусством, восстанавливая искусство индустриальное-рабочего, шофера и летчика. Город, как паук, запутывает провинцию телеграфными проволоками и устраивает по ней железные дороги внизу, в земле, и вверху, в воздухе. Притаскивает провинцию по железным дорогам, как паук муху в свой центр, перерабатывая сознание ее в своей центрифуге, обращая рыхлость ее в энергийную линию и возвращает обратно в виде жести, стекла, тока.
}

Their dynamic elements could not develop in the provinces, outside the metal culture, which fights with all the suburbs, deep provinces and the architecture of capitals, fights with peasant art, restoring industrial art - worker, chauffeur and pilot. The city, like a spider, entangles the province with telegraph wires and arranges railways on it below, in the ground, and above, in the air. It pulls the province by rail, like a spider pulls a fly to its center, processing its consciousness in its centrifuge, turning its looseness into an energy line and returns it back in the form of tin, glass, current. ${ }^{74}$

The image of a city that spreads its roads outward like spider webs, only to drag all those caught within towards the city's center-explosion of the vast system of Newtonian linear communication followed by the implosion, contraction, and simultaneity of the electric age-is in striking similarity with McLuhan's vision of the electric technology. As it is mentioned earlier, McLuhan emphasizes that movement beyond certain speed creates an acceleration that decentralizes, producing a tension between the older forms of technology and the new electric whirls of dynamic movement. McLuhan states: "All electric forms whatsoever have a decentralizing effect, cutting across the older mechanical patterns like a bagpipe in a symphony." ${ }^{75}$ In Malevich, we can witness this conflict between the province and the city, the railroad and the airplane, candlelight and electric lamp. Conflict, however, is the necessary 
condition for the creation of new forms of art, according to Malevich: “Световые явления природы действуют на известную группу нервной системы, порождают живописные конфликты и, преодолевши их, создают систему, ту или другую форму живописи, светописи, цветописи" (Light phenomena of nature affect a certain group of the nervous system, give rise to painterly conflicts and, having overcome them, create a system, one or another form of life-painting, light-painting, colour-painting) ${ }^{76}$

Malevich understands creative act as a destabilization of the nervous system of a painter who infects the body of a painting with a new additional element, whose form and structure is intimately related to technological environment: agrarian rural culture of a realist painting is followed by the industrial / electric culture of Cubism, Futurism, and Suprematism. Malevich embraces electrologic vision of reality. He sees all processes as transformations of energy from one form to another. His theory of the additional element, even though claiming to be focused on studying artistic culture alone, in fact is much more general and aspires to theorize the totality of all human action upon and interaction with the world. For Malevich, human beings are electric machines driven by what he defines as an internal energy conductor. (The term "conductor," according to Alexandra Shatskikh, was used to describe a metallic sphere in an electric apparatus. It was purposed for storage of electric charges. $)^{77}$ Malevich explains that the reasons for a particular behaviour are the experienced-by-an-individual circumstances, which demand expenditure of energy resulting in a discharge of the individual's inner conductor:

\footnotetext{
Ясно, что причиной того или иного поведения являются обстоятельства как побудители нарушившие и разрядившие кондуктор энергии того или иного индивида, воздействовавшие на определенный пучок нервной системы, связанный с кондуктором того или иного центра восприятия, ибо от попадания и способности восприятия извне воздействий и зависит поведение, т.е. разряжение той или иной формы.

It is clear that the reasons for this or that behaviour are the circumstances as the motivators that disturb and discharge the conductor of the energy of an individual, influencing a certain bundle of the nervous system associated with the conductor of a particular perception center, since behaviour depends on the penetration of external effects and ability to perceive them, i.e. discharge of one form or another. ${ }^{78}$
} 
An act of making, on the contrary, involves a release of energy from the transformation of natural materials. Malevich notes a fundamental difference in how this energy is received: an engineer wrestles with it, while an artist enjoys the forms of nature that become reflected on his/her canvas. Malevich approaches Heidegger's criticism of forceful engagement with natural forms, the challenging forth of resources so characteristic of modernity, when he writes:

Само поведение у них разное-инженер ведет борьбу со стихией, художник отображает, наслаждаясь ею. Первому она опасна, второму-прекрасна, следовательно, получая от одного источника силу воздействия, каждый по-иному воспринимает, одному она видится опасной, другому-прекрасной. Одна и та же энергия выразится в совершенно противоположных формах, с разными нормами, отношениями. Стихия для инженера-раздраженная природа, и он хитро противопоставляет ее же элементы другому ее состоянию. Природа для инженера-вечный конфликт, который пытается уладить созданием утилитарной вещи. Это не есть отображение, а борьба путем создания новой человеческой культуры как контрстихии, поэтому у инженера и появляются вещи, не похожие на природу.

The behaviour itself is different - the engineer is fighting with the element, the artist represents, enjoying it. It is dangerous to the first, beautiful to the second, therefore, receiving from one source a force of influence, each perceives differently, to one it seems dangerous, to the other, beautiful. The same energy will be expressed in completely opposite forms, with different norms, relations. The element for an engineer is an irritated nature, and he slyly contrasts its elements with its other state. Nature for the engineer - an eternal conflict that s/he tries to settle by creating utilitarian things. This is not representation, but a struggle by way of creating a new human culture as a counter-element; therefore the engineer creates things that do not resemble nature. ${ }^{79}$

Nature for an engineer is a never-ending conflict. For a realist artist, however, it is "единое, органическое, безмолвное, тихое, покойное, согласное, поэтому у него на холстах возникает природа как таковая." ${ }^{\circ 0}$ But there is also another type of artist, who takes this energy received from the forms of nature and transforms it, creating new, never-before-seen painterly forms. It is this type of energy-transforming artists that Malevich praises the most: “Таковые индивиды относятся к первой категории производящих изобретателей. Их нервная система, очевидно, должна страдать раздражительностью, доходящей до видения в явлениях новых образов, способна ассоциировать, обобщать и создавать новые явления ; таковая категория главная, без нее мы бы не двинулись ни на шаг” (Such individuals belong to the first category of producing inventors. Their nervous system, obviously, should suffer from irritability, reaching the vision in the phenomena of new images, able to associate, synthesize 
and create new phenomena; This category is the main one, without it we would not move a single step). ${ }^{81}$

\section{Conclusions:}

Malevich envisions an artist as a conductor of energy flows; an artist transforms experiences of reality, received through the excitation of the nervous system, into artistic forms carrying this transformed energy in order to, in turn, excite the nervous systems of spectators. This understanding of the role of the artist positions Malevich as an electrologic thinker, who, following the steps of Cubists and Futurists, abided to electromagnetic principles by avoiding linear perspective, expressing dynamism of ever-changing reality, and taking on the challenge of portraying simultaneity of time and space. Within Malevich's oeuvre, there is also a felt presence of ideas that originated within the field of thermodynamics, which in many ways can be considered a precursor to the electrologic revolution, and, as such, borders with the mechanical vision of reality propagated by Newtonian physics. Some views of the proponents of thermodynamics, such as those of Ostwald, subscribe to an understanding of reality as flux and highlight transformation of energy as the primary physical process. Other notions lead to more rigid and even mechanistic view of life, such as the theories of biomechanics explicated by Gastev. Malevich stays undeterred by the latter, while fully embracing monistic view of the universe as energy offered by Ostwald. The artist is also inspired by tectological analyses of Bogdanov, the forerunner of cybernetics, and borrows his ideas for understanding systems in art. Curiously, this interest of Malevich in systems reminds us that Malevich and contemporary digital artists belong to the same intellectual timeline of electrologic artists, who continue the project of grasping the meaning of the paradigmatic shift in worldviews, of electromagnetic revolution. 
${ }^{1}$ Marshall McLuhan, The Gutenberg Galaxy: The Making of Typographic Man (Toronto: University of Toronto Press, 1962), 3.

${ }^{2}$ As quoted in Crosbie Smith, "Force, Energy, and Thermodynamics," in The Cambridge History of Science, vol. 5, ed. Mary Jo Nye (Cambridge, MA: Cambridge University Press, 2002), 289.

3 Ibid., 301.

${ }^{4}$ As quoted in Smith, 301.

${ }^{5}$ As quoted in Charlotte Douglas, "Energetic Abstraction: Ostwald, Bogdanov, and Russian Post-Revolutionary Art," in From Energy to Information: Representation in Science and Technology, Art, and Literature, ed. Bruce Clarke and Linda Dalrymple Henderson (Stanford, CA: Stanford University Press, 2002), 77.

${ }^{6}$ Bruce Clarke, "From Thermodynamics to Virtuality," in From Energy to Information: Representation in Science and Technology, Art, and Literature, ed. Bruce Clarke and Linda Dalrymple Henderson (Stanford, CA: Stanford University Press, 2002), 17.

${ }^{7}$ Ibid., 18.

${ }^{8}$ William Thomson, “On the Dynamic Theory of Heat. Part V. Thermo-electric Currents," Transactions of the Royal Society of Edinburgh 21 (1857): 123.

${ }^{9}$ Bruce Clarke, "From Thermodynamics to Virtuality," 22.

${ }^{10}$ Charlotte Douglas, "Energetic Abstraction: Ostwald, Bogdanov, and Russian PostRevolutionary Art," 76.

11 Janet Stewart, "Sociology, Culture and Energy: The Case of Wilhelm Ostwald's 'Sociological Energetics' - A Translation and Exposition of a Classic Text," Cultural Sociology 8, no. 3 (2014): 334.

12 Bernadette Bensaude-Vincent, "Revisiting Controversy on Energetics," in Wilhelm Ostwald at the Crossroads Between Chemistry, Philosophy and Media Culture, ed. Britta Görs (Leipzig: Leipziger Universitätsverlag, 2005), 14.

${ }^{13}$ R. Bruce Elder, Harmony and Dissent: Film and Avant-garde Art Movements in the Early Twentieth Century (Waterloo, Ont.: Wilfrid Laurier University Press, 2010), 335.

${ }^{14}$ Charlotte Douglas, "Energetic Abstraction: Ostwald, Bogdanov, and Russian PostRevolutionary Art," 77.

${ }^{15}$ R. Bruce Elder, Harmony and Dissent, 335.

${ }^{16}$ Wilhelm Ostwald, “The Modern Theory of Energetics,” Monist 17, no. 4 (1907): 490. 
${ }^{17}$ Ibid., 487.

${ }^{18}$ Ibid., 486.

${ }^{19}$ Kazimir Malevich, "God is not Cast Down: Art, Church, and Factory" [1920], in Sobranie sochinenii v piati tomakh [Collected Works in Five Volumes] (Moscow: Gileia, 1995-2004), vol.1, 264 (translation mine).

${ }^{20}$ Kazimir Malevich, "The World as Non-Objectivity (Fragments)" [1926], in Sobranie sochinenii v piati tomakh [Collected Works in Five Volumes] (Moscow: Gileia, 1995-2004), vol. 2, 41 (translation mine).

${ }^{21}$ Kazimir Malevich, "Tsvetopis' [neologism that can be roughly translated as 'Colour-writing']" [1916-1918], in Sobranie sochinenii v piati tomakh [Collected Works in Five Volumes] (Moscow: Gileia, 1995-2004), vol. 5, 67 (translation mine).

22 Ibid.

${ }^{23}$ Charlotte Douglas, "Energetic Abstraction: Ostwald, Bogdanov, and Russian PostRevolutionary Art," 78.

${ }^{24}$ Zenovia A. Sochor, Revolution and Culture: The Bogdanov-Lenin Controversy (Ithaca, N.Y.: Cornell University Press, 1988), 182.

${ }^{25}$ Nadezhda Krupskaja, Osnovy Politiko-prosvetitel'noj Raboty (Moscow: Direct-Media, 2014), 50 .

${ }^{26}$ As quoted in Vera Aginskaja, "Roman Zamjatina My v Kontekste Proizvedenij I Idej Proletkul'ta," Canadian - American Slavic Studies 45 (2011): 368.

${ }^{27}$ As quoted in Charlotte Douglas, "Energetic Abstraction: Ostwald, Bogdanov, and Russian Post-Revolutionary Art," 83.

28 Ibid., 79.

29 Ibid., 83.

30 Ibid.

${ }^{31}$ A. A. Bogdanov, Tektologija: Vseobshhaja Organizacionnaja Nauka. vol. 1. (Moscow: Ekonomika, 1989), 69.

32 Ibid., 69-70.

${ }^{33}$ As quoted in Vera Aginskaja, "Roman Zamjatina My," 378 (translation mine). 
${ }^{34}$ As quoted in Aginskaja, "Roman Zamjatina My," 382 (translation mine).

${ }^{35}$ Kazimir Malevich, "On New Systems in Art” [1919], in Sobranie sochinenii v piati tomakh [Collected Works in Five Volumes] (Moscow: Gileia, 1995-2004), vol. 1, 155 (translation mine).

${ }^{36}$ Julia Vaingurt, Wonderlands of the Avant-Garde: Technology and the Arts in Russia of the 1920s (Evanston, IL: Northwest University Press, 2017), 8.

${ }^{37}$ Kazimir Malevich, “On New Systems in Art,” 184 (translation mine).

${ }^{38}$ Kazimir Malevich, "Letter from Malevich to S. M. Eisenstein, 13 August 1928, Tarasovka," in Malevich o Sebe, Sovremenniki o Maleviche: Pis'ma, Dokumenty, Vospominaniia, Kritika: V 2kh Tomakh, eds. I.A.Vakar and T. N. Mikhienko (Moscow: RA, 2004), vol. 1, 201 (translation mine).

${ }^{39}$ Renato Barilli, The Science of Culture and the Phenomenology of Styles (Montréal, Québec: McGill-Queens University Press, 2012), 7.

40 Ibid., 64.

${ }^{41}$ Ibid., 7.

42 Ibid., 8.

${ }^{43}$ Eric Partridge, Origins: A Short Etymological Dictionary of Modern English (London: Routledge \& Kegan Paul, 1966), 761.

${ }^{44}$ R. Bruce Elder, Cubism and Futurism: Spiritual Machines and the Cinematic Effect (Waterloo, Ontario: Wilfrid Laurier University Press, 2018), 5.

${ }^{45}$ Renato Barilli, The Science of Culture; R. Bruce Elder, Cubism and Futurism.

${ }^{46}$ Kazimir Malevich, "'Supremus.' Cubism and Futurism” [1916-1918], in Sobranie sochinenii $v$ piati tomakh [Collected Works in Five Volumes] (Moscow: Gileia, 1995-2004), vol. 5, 52 (translation mine).

47 Jonathan Coopersmith, Electrification of Russia, 1880-1926 (Ithaka, NY: Cornell University Press, 2016), $42 \& 99$.

${ }^{48}$ Ibid., 151.

${ }^{49}$ Ibid., 175.

${ }^{50}$ Ibid., 154. 
${ }^{51}$ John Milner, "Malevich: Becoming Russian," in Malevich, ed. Achim Borchardt-Hume (London: Tate Publishing, 2014), 37.

${ }^{52}$ R. Bruce Elder, Cubism and Futurism, 42.

${ }^{53}$ Ibid., 143.

${ }^{54}$ John Milner, Kazimir Malevich and the Art of Geometry (New Haven: Yale University Press, 1996), 36 .

${ }^{55}$ Marshall McLuhan, The Gutenberg Galaxy, 83.

${ }^{56}$ Ibid.

${ }^{57}$ Ibid., 276.

${ }^{58}$ Renato Barilli, The Science of Culture, 62.

${ }^{59}$ Ibid.

${ }^{60}$ Kazimir Malevich, “On New Systems in Art” [1919], 179-180 (translation mine).

${ }^{61}$ Kazimir Malevich, "Suprematism as Pure Knowledge" [1922], in Sobranie sochinenii v piati tomakh [Collected Works in Five Volumes] (Moscow: Gileia, 1995-2004), vol. 3, 134 (translation mine).

${ }^{62}$ Marshall McLuhan, The Gutenberg Galaxy.

${ }^{63}$ Kazimir Malevich, "A Note on the Limits of Reality" [1919-1922], Sobranie sochinenii v piati tomakh [Collected Works in Five Volumes] (Moscow: Gileia, 1995-2004), vol. 5, 192 (translation mine).

${ }^{64}$ R. Bruce Elder, Cubism and Futurism, 469.

${ }^{65}$ Ibid.

${ }^{66}$ Kazimir Malevich, "1/47. Suprematism. The World as Non-Objectivity" [1924], in Sobranie sochinenii v piati tomakh [Collected Works in Five Volumes] (Moscow: Gileia, 1995-2004), vol. 4, 193 (translation mine).

${ }^{67}$ Ibid., 192.

${ }^{68}$ Marshall McLuhan, Understanding Media: The Extensions of Man (Cambridge, MA: MIT Press, 1994), 182-185.

${ }^{69}$ R. Bruce Elder, Cubism and Futurism, 168. 
${ }^{70}$ As quoted in R. Bruce Elder, Cubism and Futurism, 329.

${ }^{71}$ Kazimir Malevich, "Introduction to the Theory of the Additional Element in Painting" [1923], in Sobranie sochinenii v piati tomakh [Collected Works in Five Volumes] (Moscow: Gileia, 1995-2004), vol. 2, 65 (translation of the image title is mine).

72 Ibid., 56 \& Alexander Bogdanov, "Celi I Normy Zhizni," in Russkij Kosmizm, ed. Boris Groys (Moscow: Ad Marginem Press, 2015), 264.

${ }^{73}$ Kazimir Malevich, "Introduction to the Theory of the Additional Element," 65 \& 98-99 (translation mine).

74 Ibid., 99.

${ }^{75}$ Marshall McLuhan, Understanding Media, 185.

${ }^{76}$ Kazimir Malevich, "Introduction to the Theory of the Additional Element," 72 (translation mine).

77 Alexandra Shatskikh, "Commentaries and Notes," in Kazimir Malevich, Sobranie sochinenii v piati tomakh [Collected Works in Five Volumes] (Moscow: Gileia, 1995-2004), vol. 2, 320.

${ }^{78}$ Kazimir Malevich, "Introduction to the Theory of the Additional Element," 68 (translation mine).

${ }^{79}$ Ibid., (translation mine).

${ }^{80}$ Ibid., (translation mine).

${ }^{81}$ Ibid., 69 (translation mine). 


\section{Chapter 7: Malevich and Film}

Introduction:

Very crudely summarized, the history of cinema's reception in Russia from 1913 to 1929

(Malevich's most active years) can be divided into three, somewhat overlapping periods: cinema as a gateway to the Symbolist ghost world, cinema as the epitome of new world's dynamism, and cinema as Socialist Realism's propaganda tool. In Malevich's art and writings these stages are well articulated in his mystical description of his encounter with the Black Square, which scholars often compare with a cinematic screen, in his emphasis on the dynamism inherent in Suprematism forms, and in his later plans to use cinema as a vehicle for disseminating his Suprematist philosophy. This chapter will elucidate Malevich's relationship with the cinematic medium, with film theory, and with contemporary film artists/filmmakers who have influenced the trajectory of Malevich's creative development. This task is of particular importance for understanding this artist's oeuvre since during the first decades of the $20^{\text {th }}$ century, the cinema was the ottima arte ("top art"), which not only influenced already existing strains of art practices but also stimulated the emergence of new aesthetic forms. ${ }^{1}$

Malevich and Cinema's Reception in Russia:

In 1913, cultural agitation in relation to cinema reached its peak in Russia, which happened in parallel with the exploding effect of the art of the Russian Futurists on public consciousness. ${ }^{2}$ As we remember from the previous chapters of this dissertation, Malevich was closely associated with the group and, among other contributions, developed innovative stage design, and costumes for the Futurist opera "Victory Over the Sun," performed in 1913. The dynamism of cinema and the dynamism of the Futurists were evidence of the new age. Futurist art was understood as closely related to the cinematic aesthetic with many early twentieth-century critics commenting 
on Futurism being influenced by the invention and popularity of cinema. ${ }^{3}$ French critic and poet Roger Allard suggested that Futurists painters must have had "a cinematograph in their bellies," and that Futurism should rather be called "cinematism." ${ }^{4}$ The Futurists themselves, however, did not fully agree on the question of cinema's relevance for their art. While Filippo Tommaso Marinetti, Carlo Carrà, and Giacomo Balla supported the notion of cinema's importance for Futurism, Umberto Boccioni and Gino Severini did not. ${ }^{5}$ When it comes to Russian Futurism, Malevich was on the side of Marinetti and shared fascination for cinema with the author of Italian Futurism's manifesto. ${ }^{6}$ Probably, the answer for Malevich's association of Futurism with cinema lies in the artist's connecting the language of abstraction to the art of cinema. In his book Cubism and Futurism: Spiritual Machines and the Cinematic Effect, R. Bruce Elder suggests that it is the association of cinema with the objective, photographic representation of reality-cinema as slices of the flow of life criticized by Bergson - that prevented Boccioni and Severini from noticing what cinema could afford. In "Cinema astratto-Musica cromatica" (Abstract Film— Chromatic Music) Bruno Corra, on the contrary, recognized cinema's language as that of abstraction, as non-objective expression akin to that of music. ${ }^{7}$ And this is how Malevich envisioned cinematic form.

At the same time as cinema was associated with Futurism, it was also being perceived through the veil of Symbolist occultism: before the cinematic vision fully entered other art forms, it was interpreted through the cultural lens of prevalent art movements. In 1915, when Malevich painted his first Suprematist canvas, the educated public's reception of cinema—only the accounts of literate audience survived as evidence- - was to a large degree informed by the Symbolist tradition. ${ }^{8}$ With the sensibilities characteristic of Symbolism, the space of cinema was associated with the otherworldly realm. In a 1914 short story "Наверно" (Naverno, Probably), a 
Symbolist author Zinaida Gippius re-visits the cultural motif of selling one's soul to the devil—a theme explored in earlier literary works, such as Goethe's Faust. In Gippius' version of the story, as a punishment for his nihilism, the story's protagonist experiences a purgatory, neither-life-nordeath state, which the author associates with the silence and monochromatic existence of actors on a film screen. ${ }^{9}$ Gippius writes: “Я шел по набережной торопливо. Шел как во сне. Как в моем сне-бела была Нева, черны далекие строения за нею. Черны встречные, черны по белому пробегающие санки, и тишина стояла такая же, как во сне.... Мелькали черные санки. Белела белая крепость за белой рекой” (I walked along the promenade hurriedly. It was like a dream. As in my dream-Neva was white, the distant buildings behind it were black. The pedestrians are black, black is the sled running through the white, and silence was the same as in a dream. ... A black sled flashed. White fortress whitened over the white river).$^{10}$ The black and white landscape described here unwittingly brings to mind Malevich's poetic description of his vision of the Black Square — the black and white painting that could have adorned the realm of Gippius' story. Malevich writes:

Полночь искусства пробила. Изящные искусства приговорены к изгнанию. Художник-кумир пережиток прошлого. Супрематизм сжимает всю живопись в черный квадрат на белом холсте. Я ничего не придумал. Я только ощутил в себе ночь и в ней я увидел новое, которое назвал Супрематизмом. Он выразил себя черной плоскостью в форме квадрата.

The midnight of art broke through. Fine arts are sentenced to exile. The artist-idol — a relic of the past. Suprematism squeezes the entirety of painting into a black square on a white canvas. I did not invent anything. I just felt the night inside me and in it I saw the new, which I called Suprematism. It expressed itself as a black plane in the shape of a square. ${ }^{11}$

Malevich speaks of the liminal experience in which he saw the Black Square. It is a space comparable with that of Gippius' border-realm of cinematic life, another dimension of reality where the world, through losing colour, becomes defamiliarized and abstracted, reminding of Malevich's black and white Suprematism. Malevich's philosophical concern for the concept of freed Nothing, which his Suprematist system was founded upon, could have attracted the artist to 
cinema's Symbolist reception as "the kingdom of shadows" (Maxim Gorky's expression), death, and, in the words of Tsivian, visualized Nothing. ${ }^{12}$

After the 1917 Revolution in Russia, cinema, as the "last born" of the arts, was proclaimed as the most uncontaminated by forms redolent of bourgeois ideology. As such, it was considered to be the most adequate for the Soviet society artistic medium, one that had great potential for development in the cultural conditions of a socialist society. ${ }^{13}$ Thus, the Symbolist esoteric vision of cinema was fused with a techno-utopian socialist optimism, which, however, was difficult to maintain in the economic reality of a country exhausted by war.

Contrary to the commonly held ideas on the State support of cinema in Soviet Russia, the filmmaking industry was underfunded. During the NEP period (1921-1928), Vladimir Lenin and Anatoly Lunacharsky, who was appointed People's Commissariat for Education after the Revolution, introduced a policy that was supposed to attract foreign investors into the Soviet film industry and stimulate film production in Russia. ${ }^{14}$ Their hopes were not realized. In the mid1920s, the most popular films in the Soviet Union were imported from Hollywood. American movie icons mesmerized Soviet citizens, whose admirations were fuelled by the press that lauded Charlie Chaplin, Mary Pickford, Buster Keaton, and others. ${ }^{15}$ When, in 1926, Douglas Fairbanks and Pickford visited Russia and attended a screening of The Battleship Potemkin, their comments were used to promote the film to the Soviet audience ${ }^{16}$ Lunacharsky understood very well that the films screened in the Soviet Union in the 1920s, whether they were produced in Russia or imported from abroad, were unsatisfactory in terms of their ideological content. He also realized that forbidding entertaining movies was not feasible - the revenue from the screening of popular films was necessary to support the production of ideologically rich material. Lunacharsky suggested injecting the popular content with the ideological message: 
Vladimir Ilyich told me that the production of new films imbued with communist ideas and reflecting Soviet reality should begin with the newsreel and that, in his view, the time to produce films of this kind had perhaps not yet arrived.

"If you had a good newsreel, serious and educational pictures, then it doesn't matter if, to attract the public, you have some kind of useless picture of the more or less usual type. Of course censorship is necessary in any case. Counterrevolutionary and immoral films have no place."

To this Vladimir Ilyich added: "As you stand on your own two feet, thanks to good housekeeping, you might even receive a certain loan for this as the general situation in the country improves. You must develop production on a broader basis and, in particular, you must promote wholesome cinema among the masses in the cities and, to an even greater extent, in the countryside."

Then, smiling, Vladimir Ilyich added: "Among our people you are reported to be a patron of art so you must remember that of all the arts for us the cinema is the most important." 17

By 1928 , it became clear that this strategy of mixing films deemed socially relevant with the pictures intended solely for entertainment purposes did not bring the desired effect, which prompted the organization of the First Party Conference on Cinema, in March 1928. The result of this meeting was a tightening of State control of the film industry in order to make cinema the political weapon the party members envisioned it to be. ${ }^{18}$ Even though Malevich started composing his ideas on film theory as early as 1925 , his practical interest in film dates to 1927 when he conceived an animated film about the evolution of Suprematism. It is not surprising that Malevich found it difficult to find support for his cinematic ideas in the climate of ideological pressure that dominated the Russian cultural landscape in the late 1920s. This lack of interest that began to border on condemnation, prompted Malevich to seek creative camaraderie abroad, in

\section{Germany.}

The role of Germany in the Russian film industry of the first decades of the $20^{\text {th }}$ century was intimately connected with Lenin's proposition of the New Economic Policy (NEP) in 1921. This policy was introduced in an effort to resuscitate the Soviet economy after the devastating years of the First World War and Civil War. A conscious reversal to capitalism, NEP promoted the creation of surplus and with it demanded the establishment of trade treaties. ${ }^{19}$ By 1922 , Soviet Russia signed the Anglo-Russian Trade Agreement and the Treaty of Rapallo, concluded 
between the Soviet Union and Weimar Germany. ${ }^{20}$ The latter agreement, which supported the trade and consular relations between the two countries, was especially important for the Soviet film industry that started to receive support from foreign investors, such as The Internationale Arbeitershilfe (IAH), a major communist organization in Germany. A number of smaller firms found investments in Soviet cinema fruitful, increasing the production of films and import of equipment to Russia. ${ }^{21}$ That Germany was a key exporter of films that enriched the Russian cinema life of the 1920 s can be witnessed from the fact that the only film poster created by Malevich was for the German film, Dr. Mabuse, der Spieler (1922) by Fritz Lang.

Thus, in the 1920s, when Malevich was most concerned with film, the artist's intellectual relationship with cinema was mainly formed by his interaction with the cultural ideas prevalent in Soviet Russia and Germany. More specifically, Malevich's understanding of film was shaped through his exposure to the Soviet filmmakers' figurative films and his subsequent introduction to the abstract cinematic works of German artists and foreign artists working in Germany. Among the key figures whose writings and art have stimulated the formation of Malevich's views on cinema were Sergei Eisenstein and Hans Richter. It is to the study of Malevich's interaction with Eisenstein's ideas on film form and Richter's analogous to Malevich's extension of his artistic practice into the temporal dimension of film that I propose to turn our attention next.

Malevich and Eisenstein:

Malevich became concerned with questions of cinematography around the mid-1920s. In many ways, the artist's interest in cinema was sparked by his encounter with the renowned Russian filmmaker, Sergei Eisenstein. Since 1910, Malevich spent his summers in Nemchinovka, a place he admired so much as to request to be buried there. In 1925, Eisenstein and Nina Agadjanova 
were working in Nemchinovka on the script for the film "The Year 1905." It is there that Malevich and Eisenstein met and befriended each other, even though their opinions regarding cinema differed. Eisenstein writes: "It is enough to remember, that it was here, at Nuney's [Nina Agadjanova]... that I first met (and grew very fond of) Kazimir Malevich, such an indefatigable, stubborn, and principled fighter, at the time of his aggressively conducted battle for the direction of the Institute [GINKhUK]."22 Eisenstein often referred to Malevich as a man of high "pictorial culture" and even based a short story "Nemchinov Post" on the events of Malevich's childhood. ${ }^{23}$

As a result of fruitful debates on the nature of art, which Malevich often shared with Eisenstein, the artist began writing articles on topics of cinema. The first one of these articles, "O выявителях: плакаты” (O vyjaviteljah: plakaty; About developers: posters ${ }^{1}$ ) was written in 1925 and published in nos. 6-8 of a cinema journal Киножурнал A.P.К. (Kinozhurnal A.R.K., Cinemajournal A.R.C. [Association of Revolutionary Cinematography]). Malevich often relied on photo-chemical metaphors borrowed from photography and cinema to allude to the inability of the human mind to perceive the world as flux: unframed fluid reality becomes fixed in the psychic mirror of the brain in the form of a negative that is processed by the brain to form a perception of reality akin to a celluloid strip. ${ }^{24}$ Taking this view of perception into consideration, it becomes clear why Malevich found interest in the advertising medium of film posters: a cinematic poster is a form of abstraction; it develops an impression of sensations formed by a film without the burden of experiencing the succession of individual frames that deliver the film's narrative, the objective reality which did not agree with Suprematist philosophy.

\footnotetext{
1 Aleksandra Shatskikh translated this essay's title as “On Exposures. Posters." I translated the title as "About Developers: Posters" to better reflect the posters' acting as a developing agent, a chemical that makes the film's impressions visible in the psychic apparatus of the intended audience to whom the poster advertises the film. "Exposure," in this content, could refer to the act of viewing the film, altering the meaning of Malevich's essay title.
} 
The aforementioned essay, written in response to the exhibition of film posters organized by the State Academy of Art in 1925, was critical of the artistic approach to poster design and accused the artists of not relying on any visual scientific system to guide their creations. Moreover, Malevich suspected that the film posters he saw at the exhibition were not effective "developers" for the advertised films because the art of cinema lacked its own individual voice imitating other art forms. Malevich states:

Плаката-выявителя до сих пор нет. В частности-нет «выявителя», специфического для кино. Но, может быть, этого специфического киновыявителя нет по той простой причине, что нет еще и самого кино? А есть только киноаппараты, заменившие собой карандаши, кисти и разноцветную палитру, как новый способ передачи тех картинок, над которыми столько сил затрачивали старые живописцы, и кино пока-только новое техническое средство в области наиболее совершенной передачи реального в искусстве, а режиссеры-это новые художники изо, произведения которых напоминают художников-статиков?

There is still no poster-developer. In particular, there is no "developer" specific to cinema. But maybe this particular film developer is not there for the simple reason that there is also no cinema itself? There are only movie cameras that have replaced pencils, brushes and a multi-coloured palette, as a new way of transferring those pictures that the old painters spent so much effort on, and cinema now - only a new technical tool in the field of the most perfect transference of the real into art, and film directors - the new painters whose works resemble the static art of the easel artists? ${ }^{25}$

Malevich suspects that a movie camera, alongside pencils and brushes, is another tool for the painters who now can achieve verisimilitude without investing as much energy as the old masters of figurative painting did. Film director is another name for a painter, whose art lacks the dynamism that is at the core of cinema's structure. Malevich's attack is directed at objective painting and its extension in the fourth dimension of time that the medium of film made possible. Film, however, must find its own language; it needs to abandon its dialect of academic painting or else it will “вечно ползать по старым гробницам и питаться объедками старого времени” (forever crawl over the old tombs and eat the scraps of the old time). ${ }^{26}$

To be precise, the conviction that new art must strive towards the creation of new forms was characteristic of the Modernist worldview. Among the proponents of this worldview were such influential theorists of Modernism in art and literature as Clive Bell and Ezra Pound, 
respectively. For Bell, art comes from the expression of emotions through form—-'Significant Form" (Bell's key concept) that brings "moments of exaltation" and arouses aesthetic pleasure from the appreciation of lines, forms, and colours. Emotions that command an artist to express them through form may come from an artist's encounter with external reality, a memory of this encounter, or imagination. In Bell's view, an artist is never bound by vision but guided by these emotions, no matter their origin, revealing why copying the appearance of reality in art is not an act of creation. In Art (1914), Bell writes:

No one ever doubted that a Sung pot or a Romanesque church was as much an expression of emotion as any picture that ever was painted. What was the object of the potter's emotion? What of the builder's? Was it some imagined form, the synthesis of a hundred different visions of natural things; or was it some conception of reality, unrelated to sensual experience, remote altogether from the physical universe? These are questions beyond all conjecture. In any case, the form in which he expresses his emotion bears no memorial of any external form that may have provoked it. Expression is no wise bound by the forms or emotions or ideas of life. ${ }^{27}$

Similarly, Ezra Pound makes a distinction between what it means to describe reality and present something new, such as a scientific discovery: representation is repetition, while presentation is addition. In "Stray Document" (1934), Pound advises:

Don't be descriptive; remember that the painter can describe a landscape much better than you can, and that he has to know a deal more about it.

When Shakespeare talks of the "Dawn in russet mantle clad" he presents something which the painter does not present. There is in this line of his nothing that one can call description; he presents.

Consider the way of the scientists rather than the way of an advertising agent for a new soap.

The scientist does not expect to be acclaimed as a great scientist until he has discovered something. He begins by learning what has been discovered already. He goes from that point onward. ${ }^{28}$

In his criticism of representational art Malevich joins the voices of Bell and Pound. Upon determining that filmmakers are following the steps of figurative painting, being engaged in descriptive work bound by ideas of life, to use Bell's and Pound's words, Malevich was able to ascertain the stage of painterly development that these filmmakers have reached — it is important to keep in mind that evolutionary theories popular at the time guided the artist's thinking. The socio-political dogmatism and moralism that dominated many Soviet films was analogous to the socially concerned art of the Wanderers, according to Malevich. ${ }^{29}$ Передвижники 
(Peredvizhniki, the Wanderers) were a group of artists active from 1863 to 1923 . They revolted against the conservatism of the Imperial Academy of Arts and became independent artists focused on painting the reality of human existence. Generally, Wanderers painted landscapes, genre paintings, portraits, and scenes displaying social inequality. It is the latter Wanderers' theme that Malevich saw re-invented in Eisenstein's works. Malevich's insight pinpoints the parallels between the socialist movements of the 1860s and the 1920s in Russia and emphasizes the influence of politics on the content of artistic works. Malevich is critical of creating art with the purpose of swaying the ideology of the State and condemns the socialist realism of the Wanderers and of the figurative artists of Soviet Russia.

For Eisenstein, however, film was to serve an ideological war-a conviction that Malevich did not share. Even though both, Malevich and Eisenstein, were deeply interested in questions of human perception, the latter used its mechanisms for the communication of revolutionary ideals—a utilitarian agenda Malevich despised. Eisenstein, who considered Revolution responsible for moulding him into an artist, ${ }^{2}$ writes in his early, autobiographical essay: “Наше кино прежде всего—oружие, когда дело идет о столкновении с враждебной идеологией, и прежде всего-орудие, когда оно призвано к основной своей деятельности—воздействовать и пересоздавать” (Our cinema is first and foremost a weapon when it comes to colliding with a hostile ideology, and above all a tool when it is called upon to its main activity—-to influence and re-create). ${ }^{30}$ Revolutionary art for Malevich was a dead-end; it was another iteration of art that aspired to paint "морда жизни" (the snout of life), except this time the "snout" belonged to the proletariat and not to the bourgeois:

\footnotetext{
${ }^{2}$ In "Autobiography," ashamed of his anti-proletariat roots, Eisenstein wrote: "Не могу похвастать происхождением. Отец рабочий. Мать не из рабочей семьи” (I cannot boast of origin. Father is a worker. Mother is not from a working family; Selected Writings in Six Volumes, vol. 1 p. 72)
} 
Если все времена разных человеческих устроительств стремились сесть в экипаж искусства и выявить свое лицо в образе через искусство, то в подражание им наша современная критика направляет современных художников в ту же сторону. Она полагает, что раз буржуазный класс выписывал себя через искусство живописца со всей своей бытовой требухой на холстах или в скульптуре, театре, музыке, поэзии, то и современному победоносному рабочему классу почему-то тоже нужно выписать свою требуху, ибо если буржуазный класс утвердил себя в искусстве, то и мы себя должны тоже вымазать на холст и утвердиться в нем по образу и подобию буржуазии.

If all the times of different human organizations sought to sit in the crew of art and reveal their faces in the image through art, then to imitate them our modern critics direct modern artists in the same direction. They believe that if the bourgeois class painted itself through the art of the painter with all the everyday tripe on a canvas or in a sculpture, theater, music, poetry, then for some reason the modern, victorious working class also needs to paint its tripe, for if the bourgeois class has asserted itself in art, then we must also smear ourselves on the canvas and establish ourselves in it in the image and likeness of the bourgeoisie. ${ }^{31}$

This stubborn adherence to objective art demonstrated by Soviet filmmakers made it impossible for Malevich, the "priest" of non-objectivity, to agree with the creative direction chosen by Eisenstein, Dziga Vertov, and others. However, upon closer examination of Malevich's and Eisenstein's writings it becomes apparent that this disagreement, even though substantial, was one of the only major issues that signaled their antithetical ideals. Among Eisenstein's primary artistic concerns was the question of the transformation of photographic images into aesthetic objects. ${ }^{32}$ Eisenstein, like Malevich, wanted to produce reality and not simply reproduce it. Transforming a photographic image into an aesthetic element strips this image, iconic sign, of its ability to communicate, creating an element that is an action rather than a statement. Aesthetic signs are dynamic, while carrying no clearly defined message. ${ }^{33}$ Eisenstein's project of manufacturing aesthetic signs from the raw material of cinematically recorded nature is akin to that of Malevich, who too wants to capture the dynamism of nature stripped of the meaning assigned to it by the human mind: "Если наука не сможет поручиться за вечность своего обоснования и доказательства, то тем самым доказует одно, что природа-

беспредметность, вне знаний стоящая, и у нее—один противоположный лозунг: 'Не знать, но действовать"' (If science cannot vouch for the eternity of its justification and proof, it will thereby prove one thing that nature - non-objectivity, standing outside of knowledge, and it has 
one opposite slogan: "Not to know, but to act"). ${ }^{34}$ In his review essay "Eisenstein, My Contemporary," R. Bruce Elder avers that determining how to transform the static iconic image into an active dynamic element, or using Malevich's words, how to revert "to know but not to act" into "not to know but to act," was the key question of Eisenstein's film theory. ${ }^{35}$

The method that Eisenstein used to achieve this result in the 1920s, a period of fruitful debates with Malevich, was his application of dialectical materialism to guide the montage of his cinematic works. ${ }^{36}$ In the aforementioned essay, Elder points out the little studied relationship between the Marxist conception of labour and Eisenstein's ideas on the transformation of the iconic image into the aesthetic form. At the core of the Marxist theory of labour is the creative conflict that arises from the transformation of the raw materials of alienated nature into useful human-made objects, bridging the divide between nature and humans. Eisenstein commonly used the word "conflict" to describe difference (akin to that between nature and human beings) that is dialectically overcome in the process of a creative struggle, "exploding" into a new aesthetic experience that is radically different from the raw materials used for its production. Dialectical logic proposes a synthesis from contradictory elements. ${ }^{37}$

Cinematography, according to Eisenstein, is primarily montage,$^{38}$ which he defines as “не мысль, составленная из сцепленных друг с другом кусков, а мысль возникающая в столкновении двух друг от друга независимых кусков" (not a thought made up of pieces linked with each other, but a thought arising in the collision of two independent pieces). ${ }^{39}$ Among these collisions/conflicts Eisenstein identified conflicts within the cinematic frame and conflicts between the frames. The former can be “конфликт графических направлений (линий), конфликт планов (между собой), конфликт объемов, конфликт масс (объемов, наполненных разной световой интенсивностью), конфликт пространств и т.д." (conflict of 
graphic directions (lines), conflict of plans (among themselves), conflict of volumes, conflict of masses (volumes filled with different light intensity), conflict of spaces, etc.). ${ }^{40}$ The latter is created when the spaces of two shots with their own individual conflicts within are clashed by juxtaposition, which accentuates their differences. The totality of the syntheses of the conflicts within the film's montage creates a new cinematic aesthetic form.

For Malevich, the concept of conflict, and the associated idea of contrast, were among the major postulates on which he based his philosophic system. Malevich spoke of conflict mainly in two contexts: as a catalyst for the creation of new visual styles and as a basis for the composition of a painting. Malevich's dialectics is apparent in his theory of artistic styles, which describes how new artistic movements are formed as a result of the conflict between the surrounding environment and an artist's consciousness. Malevich writes:

\begin{abstract}
Световые явления природы действуют на известную группу нервной системы, порождают живописные конфликты и, преодолевши их, создают систему, ту или другую форму живописи, светописи, цветописи. Строения цветовых отношений вызывают новый строй цветописи, и приявшие эту систему создают профессию живописи, которая может разделиться на профессоров, преподавателей. Во главе их стоит живописец, являясь причиной их действия, он занят урегулированием взаимных отношений цветовых явлений бытия на него, формирует их в произведение, создавая разные системы живописных строений; таким образом, живописное произведение есть результат отношений между субъектом и объектом, которое при удачном соотношении вступает в форму произведения импрессионистического, дивизионистического, сезаннизма, кубизма и т.д., и благодаря этому наступает конфликтное разрешение, образующее новое направление искусства (№ 52,53).

Nature's light phenomena act on a certain group of the nervous system, giving rise to painterly conflicts and, having overcome them, create a system, one or another form of live painting, light painting, colour painting. The structures of colour relations cause a new system of colour painting, and those who adhere to this system create a painting profession that can be divided into professors and teachers. At their head stands the painter, being the cause of their action, he is busy regulating the relationships between the colour phenomena found in reality of existence and acting upon him, forms these relationships into works of art, creating different systems of painterly constructions; thus, the pictorial work is the result of the relationship between the subject and the object, which, with a good ratio, enters the form of a work of impressionism, divisionism, cesannism, cubism, etc. and as a result comes the resolution of the conflict, forming a new direction in art. ${ }^{41}$
\end{abstract}

Similarly, Malevich understands the creative process of painting dialectically, as a product of the synthesis of contradicting elements: 
The same creative surface appeared before the artist-creator - his canvas, the place where the intuition builds his world and also the flowing forces of painterly and colour energies are regulated by him in various forms, lines, planes; he also creates forms, individual elements of their signs and achieves a unity of contradictions on his painterly surface. Thus the creation of the contrasts of forms brings to being a unified harmony of the body of the construction, without which creation is inconceivable. ${ }^{42}$

It is apparent that Malevich agrees with Eisenstein on the primary role of conflict in the creation of new aesthetic forms. In Eisenstein's reliance on the rule of contrasts, Malevich sees a favourable development of the filmmaker's cinematic vocabulary. However, following his evolutionary theory of the development of artistic forms, Eisenstein is yet to undergo the Cubist stage of evolution before arriving at the Futurist, and finally, Suprematist aesthetics. Malevich writes:

Эйзенштейн обратил внимание на закон контраста, который делает его кинопостановку интересной, но ему должно обратить внимание на то, что его контрасты могут создать обстановку, в которой идея может выиграть, но контрасты как таковые в таком случае утеряют свою собственную остроту и контраста как такового при данном условии не выявят. Если закон контрастов будет им осознан, а осознан он может быть только через кубизм как единственную школу о законах контраста, тогда он окажется на высоте, на которой стоит новое искусство будущей культуры.

Eisenstein drew attention to the law of contrast, which makes his film production interesting, but he should pay attention to the fact that his contrasts can create an environment in which an idea can win, but contrasts as such will lose their own sharpness and contrast as such in these conditions will not be revealed. If he grasps the law of contrasts, and the only way to grasp it is through cubism as the only school on the laws of contrasts, then he will reach the height at which the new art of the future culture stands. ${ }^{43}$

Eisenstein, in turn, doesn't lose an opportunity for a counterattack. In his major theoretical essay

“The Fourth Dimension in Film," the filmmaker opposes a tendency to analyze painterly

elements of individual frames, arguing for the meaninglessness of this endeavour since it is the

totality of conflicts within various categories that is important for the creative effect of a

cinematic work. Eisenstein cites Malevich as an example of a dilettante eager to apply his

knowledge of a painter to analyzing film:

Рассуждать о живописности кадра в кинематографе-наивно. Это под стать людям неплохой живописной культуры, но абсолютно неквалифицированным кинематографически. К такому типу рассуждений могут быть отнесены, например, высказывания о кино со стороны Казимира Малевича. Разбирать «кинокадрики» с точки зрения станковой живописи не станет сейчас ни один киномладенец.

To talk about the painterly qualities of an individual frame in cinema is naive. This is a match for people of a good pictorial culture, but cinematographically absolutely unqualified. This type of reasoning can 
include, for example, statements about cinema from Kazimir Malevich. Nowadays, not a single cinemachild will deconstruct "film frames" from the point of view of easel painting. ${ }^{44}$

The debate on cinema between Eisenstein and Malevich is even more intriguing if we take into account that the two artists have been nourished by the same intellectual soil. In his paper "Ejsensteijn, Symbolisme and the Occult," R. Bruce Elder argues that Eisenstein was in many ways an heir of the Symbolist tradition and was deeply interested in such Symbolist concerns as the concept of transformation, the act of artistic creation as theurgy, and the unity of contradicting elements, such as the one achieved in the experience of synaesthesia. Malevich, too, had a strong connection to the legacy of the Symbolist movement.

One of the ways in which Malevich's and Eisenstein's theories of art intersect is in their interest in "transformationalism." To be precise, fascination with this concept was widespread among Russian artists of that period. The language of modern Russian art was deeply saturated with metaphors related to biology, ${ }^{45}$ which, together with concepts borrowed from the occult and alchemical doctrines, set forth "transformationalism" as the driving force for visual and conceptual developments in the arts. ${ }^{46}$ Eisenstein endorsed the idea that through cinema it was possible to change the consciousness of the viewer, and, consequently, to fully transform society, ushering in a new era of existence. ${ }^{47}$ Moreover, the filmmaker maintained that it was scientifically possible to establish the exact amount of physical stimuli to reform an individual through cinema. ${ }^{48}$ Malevich's Suprematism, too, was intended as a visual tool with which to attune the spectators to the rhythms of the non-objective world, disintegrating all into the ontological no-thing. The conviction that art can transform the world can be attributed to the writings of Nikolai Feodorov, among others. In the chapter on Malevich, Tsiolkovsky, and Feodorov, I discussed Malevich's aspiration to conquer space, an intent that was supported by the artist's sketches for space dwellings. Besides influencing Malevich's architecture, an 
infatuation with Feodorov's ideas can be witnessed in other aspects of Malevich's art. There is an intellectual alignment between Feodorov's cosmic evolution that leads towards the final goal of total integration of humankind into a whole ${ }^{49}$ and Malevich's evolutionary Suprematism of the totality of non-objectivity. Both treat this process as aesthetic and creative. ${ }^{50}$ Feodorov writes: “...Великие художественные произведения... изображая мир в себе, они отрицают его. Нет такого действительно художественного произведения, которое не производило бы некоего изменения в жизни... художественное произведение есть проект новой жизни (Great works of art ... depicting the world in themselves, they deny it. There is no such really artistic work that would not make any change in life ... a work of art is a project of a new life)."51 The transformative element in art as theorized by Feodorov served as a guiding principle in Malevich's practice. The "project of new life" was the key concern of Suprematism. Malevich explains: “Форма супрематизма утверждается необходимостью живописного существования на данном холсте,-так создается реальная жизнь, более реальная, более утвердительная, чем все вещи, чем все живые и мертвые формы природы.... (The form of Suprematism is affirmed by the need for a painterly existence on a given canvas - in this way real life is created, more real, more assertive than all things than all living and dead forms of nature)."

Eisenstein, too, embraced the transformational aspect of art and the idea of generating new life through a creative process. These convictions found expression in his theory of film, particularly, in the theorization of montage discussed earlier in this chapter. ${ }^{53}$ Eisenstein's own technological utopianism resonates with that of Feodorov and his promise of conquering death through harnessing the possibilities of science and art, which, ideally, are one and the same creative force. ${ }^{54}$ A new reformed humanity is the goal of both Eisenstein's and Feodorov's belief 
that art, ideas, and technics might spur evolution. In the Symbolist ideas of transformation and generation of new life via art, we can witness the intellectual affiliation between Eisenstein and Malevich as being especially pronounced. One can almost hear the echoes of Eisenstein and Malevich's discussions on the nature of art in the following passage describing the difference between acting as a living creative process and acting as lifeless repetition of actions. Eisenstein writes:

there are fights and fights. There is the fight which is planned and rehearsed, in which the chosen scenario unfolds move by move and action by action just as it was planned; and yet that fight will be as lifeless, ineffective, unconvincing and emotionally unexciting as the depiction of a fight in "long shot" on the screen. On the other hand, there is the fight in which every phrase "arises" in the spectator's eyes... [I]t is ... created, brought to life, as the active expression of an emotional logic deriving from the aims which the actors set themselves in their progression from phase to phase of the action... Its effect will be distinctive to the same extent that the effect of the montage-structured fight differs from the fight shot in one set-up in long shot. The art of montage in film-making is not an analogy with but is exactly the same thing as an actor's playing on stage; provided that the actor is not playing something ready-made but if, instead, his playing is a process within which, step by step, emotions are brought into being that are in true accord with the circumstances. ${ }^{55}$

Eisenstein envisions actor's actions not as a set of pre-conceived movements, lifeless in the monotony of repetition, but as a manifestation of emotional logic that guides the body to move in accordance with the necessity of the moment, directed by a compelling cosmic force: acting ceases to be a copy of reality but instead is affirmed as life itself.

The claim that art is a theurgic act that brings new beings to life - that artists create life in a god-like process of art making — belongs to the Symbolist tradition. One of the most prominent Symbolist figures in Silver Age Russia, Andrei Bely, ascribed life-giving properties to the act of naming - a conviction to a large degree inspired by Bely's close familiarity with the Name Worshipping sect's beliefs, discussed in the chapter on Malevich and Infinity. Bely wrote: “Язык-наиболее могущественное орудие творчества. Когда я называю словом предмет, я утверждаю его существование" (Language is the most powerful tool of creation. When I call 
an object a word, I affirm its existence). ${ }^{356}$ In his book, Harmony and Dissent, R. Bruce Elder

notes that this Symbolist treatment of language as having magical powers and of words as signs capable of conjuring up an object has a lot in common with the language of cinema. In cinema, objects-signs captured on film appear to conjure up the actual natural objects, creating a new cinematic reality. ${ }^{57}$ By taking a dialectical approach, which involves a synthesis of contradicting forms, both Eisenstein and Malevich aspired to bring to life new artistic entities, whether on a cinematic or a painterly canvas.

The two artists further explored this Symbolist theurgic legacy of establishing synthetic unity, or "total image" using Eisenstein's terminology, through the investigation of synesthesia, a perceptual phenomenon that leads to experiencing an intermingling of a variety of sensual stimuli, such as colour and sound, sound and smell, sound and graphic line. ${ }^{58}$ For the Symbolists, synaesthesia was a way to announce the unity and harmony of the world through establishing connections between things of different nature. Here Malevich explains how the mind pictures sound in visual form:

It is as if a canvas is a trace of the state of colour energy, which compresses into a line, or into a surface, a spot of various states; just like in music, sound is strictly assembled and encapsulated in the graphic form of a musical sign, a sort of auricular suitcase that sound is locked into, but when released in the instrument and freed in space, it comes into the ear in the form of the same spots of different magnitudes, in curves and in direct waves, being drawn on the brain negative ${ }^{4} .{ }^{59}$

Malevich's remarks on synaesthesia evince his knowledge of Maxwell's equations_-for Malevich sound and colour are forms of energy: the energy of sound enters the mind and becomes transformed into the energy of light waves; it is not only heard but also viewed in the

\footnotetext{
${ }^{3}$ It seems relevant to mention that Bely, alongside Malevich and Eisenstein, was, too, deeply influenced by Feodorov's Cosmism (Feodorov 1982, footnote on p. 48).

${ }^{4}$ Under negatives, Malevich understands the ideas about reality we hold true, the 'undeveloped' images of nature refracted through the brain's lens, the eyes. It appears that Malevich uses this photochemical term to stress the active role the human mind plays in processing of the stimuli received through the senses. The mind 'develops' these mental imprints, negatives, into images of reality.
} 
mind's eye/ear as forms of one and the same energy perceived by different sense organs

simultaneously.

Eisenstein announces his views on synaesthesia in a consciously convoluted manner. As

Elder comments in "Ejsensteijn, Symbolisme and the Occult," the filmmaker could not openly

discuss his ideas on a topic that the Soviet government could have considered frivolous, and

instead disguised his genuine interest behind the veil of critical antagonism (p. 20). In "Colour

and Sound," Eisenstein writes:

Теперь, решив это основное положение о звукозрительном монтаже, надо сейчас же со всей решительностью дать отпор одной ошибочной точке зрения, которая ходит по мозгам западных искателей.

Той мысли, что соответствие звука и цвета-абсолютны. Что определенному оттенку цвета абсолютно соответствует абсолютный тембр и тон в музыке и звуке.

Now, having decided this basic position on the sound-visual montage, one must immediately with all determination resist one erroneous point of view that runs through the brains of the Western seekers.

That thought that the correspondence between sound and colour is absolute. That a certain shade of colour absolutely corresponds to an absolute timbre and tone in music and sound. ${ }^{60}$

On the following pages of Eisenstein's essay he, indeed, effectively and decisively critiques the

notion of the absolute correspondence of colour and sound. Later in the essay, however, it

becomes apparent that in the phrase "the absolute correspondence of colour and sound" the

filmmaker disagrees with only one word- "absolute," fully embracing the meaning of the rest of

the phrase. Eisenstein states:

Это отсутствие (или неуловимость?) абсолютного соответствия в искусстве не есть ограничение. С одной стороны, это вечный стимул в системе новых и новых образов искать новых случаев этого внутреннего слияния звуков и цветов, с другой стороны, раз навсегда заданное абсолютное соответствие, то есть раз навсегда зафиксированная картина взаимосопутствующих ассоциаций была бы глубоко чуждой самой природе искусства. Ибо в задачи искусства входит прокладывать новые трассы в области познания действительности, создавая новые цุепи ассоциащиий на базе использования существующих.

This absence (or elusiveness?) of absolute correspondence in art is not a limitation. On the one hand, it is an eternal stimulus to look for new cases of this internal fusion of sounds and colours in the systems of new images, on the other hand, a once-and-for-all-given absolute correspondence, that is, once-and-for-all fixed picture of mutually accompanying associations would be deeply alien to the nature of art. For the task of art is to lay new tracks in the field of knowledge of reality, creating new chains of associations based on the use of the existing ones. ${ }^{61}$ 
Eisenstein argues against the static system of correspondences between sound and colour and proposes to aspire achieving unique synesthetic relationships within a given artwork. In one of his autobiographical notes titled "Colour," Eisenstein, without any disguise, establishes equivalence between colour and sound. With the brevity and richness worthy of a poet, Eisenstein writes: “Цвет. Чистый. Яркий. Звонкий. Звенящий. Когда а полюбил его? Где?” (Colour. Pure. Vivid. Sonorous. Tinkling. Where did I fall in love with it? When?). ${ }^{62}$ Here, Eisenstein does not write about synesthesia, he writes as a synesthete: the filmmaker's ability to hear the sound of colour betrays him as someone who bears the gift of synesthesia.

From this study it becomes apparent that Malevich and Eisenstein developed their theories of film through intellectual exchange, demonstrating a shared interest in dialectics as a guiding principle in creating new artistic realities. The Symbolist legacy is manifested in the primary role of the concept of transformationalism and allusions to synesthetic experiences played in Malevich's and Eisenstein's writings. While retaining their idiosyncratic convictionsMalevich could not accept Eisenstein's insistence on using art as a vehicle for the dissemination of a political agenda — the two thinkers cross-pollinated each other's ideas and created new systems of art, in part, through conflict between their individual views.

\section{Malevich and Richter:}

In his memoirs titled Encounters from Dada till Today, the German artist and filmmaker Hans

Richter (1888-1976) writes:

When the First Russian Art Exhibition opened at the Galerie Van Diemen in Berlin during the winter of 1922, we were astonished (as Central and Western Europeans) to see what had been going on in Russian art during the war and the revolution. Altogether independently, cut off by the war and by wartime censorship from Germany, France, the Netherlands, and Switzerland, Russian artists had been engaging in experiments that were very similar to those of the West. They too had been attempting to discover the elements of a new formal language.

The artist who pioneered this movement in Russia was Malevich, but he was by no means alone. Behind him was a Russian avant-garde corresponding to the De Stijl group around Mondrian in the Netherlands. Obviously, a historic task was being undertaken simultaneously by various independent groups of the younger generation between 1910 and 1920, in both the East and the West. ${ }^{63}$ 
As Richter indicates in his memoirs, the parallels between the art of the Russian avant-garde, De Stijl and his own are uncanny. In the early 1920s, Richter, whose eclectic artistic concerns prompted him throughout his creative life to join and re-join the Dadaists, Surrealists, and Constructivists, was a leading member of The Konstruktivistische internationale schöpferische Arbeitsgemeinschaft (Constructivistic International Creative Workshop). One of the major theoretical and creative projects of the 1920s for Richter and his colleague Viking Eggeling was the development of a universal language consisting of abstract forms, which, through their simplicity and efficiency of design that allowed omitting the confusion of traditional languages, were to be widely comprehended, assisting in restructuring communities worldwide. Gert Caden, one of the attendants of the second congress of the Constructivistic International Creative Workshop, writes in dialogue with Richter and Eggeling's ideas on the Universelle Sprache:

Not the personal 'line' - what anyone could interpret subjectively - is our goal, but rather the work with objective elements: circle, cone, sphere, cube, cylinder, etc. These elements cannot be objectified further. They are put into function; the painting also consists of complementary tensions in the colour-material and the oppositions of vertical, horizontal, diagonal. [...] Thus a dynamic-constructive system of force is created in space, a system of innermost lawfulness and greatest tension.... That is the formal side of our efforts. ${ }^{64}$

Malevich's Suprematism, in which the square, circle, and cross are “главные формы, знаки моего строительства" (main forms, signs of my construction), ${ }^{65}$ is in many ways comparable to Richter and Eggeling's Universelle Sprache: it aspires to be its own language devoid of the dramaturgy of everyday life. In Malevich's view, Suprematism is an efficient system of communication since it is able to avoid the traps of logic, reason, and psychology. Malevich alludes to the biblical story of The Tower of Babel, equating Suprematism with the universal language shared by the united people of the Old Testament:

Вся бывшая и современная живопись до супрематизма, скульптура, слово, музыка были закрепощены формой натуры и ждут своего освобождения, чтобы говорить на своем собственном языке и не зависеть от разума, смысла, логики, философии, психологии, разных законов 
причинности и технических изменений жизни. То было время вавилонского столпотворения в искусстве.

All earlier and contemporary painting before suprematism, sculpture, the word, music were enslaved by the form of nature and are waiting for their release, to speak their own language and not to depend on reason, meaning, logic, philosophy, psychology, different laws of causality and technological changes in life. That was the time of the Babylonian pandemonium in art. ${ }^{66}$

Similarly to Universelle Sprache, Suprematism strives towards being an objective system of communication that is not obscured by psychological innuendoes: "Конструируется система во времени и пространстве, не завися ни от каких эстетических красот, переживаний, настроений, скорее является философской цветовой системой реализации новых достижений моих представлений как познание" (A system is constructed in time and space, not depending on any aesthetic beauties, experiences, moods, rather it is a philosophical colour system for the realization of $\quad$ new achievements of my ideas as an act of knowing.) ${ }^{67}$ It is astounding that these two projects, Malevich's Suprematism and Richter and Eggeling's Universal Language, were being developed independently of each other.

Malevich was well aware of Richter's abstract films, in particular of Rhythmus 21, information about which was published in the 1922 issue of Кино-фот (Alekseo Gan's Constructivist periodical) in Ludwig Hilbersheimer's article “Динамическая живопись” (Dynamic painting). In 1923 and 1925, Richter completed two other abstract films titled Rhythmus 23 and Rhythmus 25, respectively. Malevich might have seen these works. Taking into account Malevich's frustration with Eisenstein's and with Vertov's insistence on objective representations in their films, one can imagine the creative excitement and sense of intellectual belonging that Malevich felt when first encountering Richter's work. Until the late 1920s, artistic trajectories of the two artists perfectly aligned: both painters were looking to extend their experimentations with painterly abstractions onto the cinematic screen. In 1926, a year before his 
visit to Berlin, Malevich favourably writes about the trajectory of filmic experimentations taking place in Europe:

In the West, important artist-painters are little by little beginning to work in the cinema, and, in beginning their work with a purely abstract element, they are beginning with our future source of new forms. This entry of the contemporary artist-painter into the cinema should bring us, and him, to a new essence and significance for the screen, as a new way of showing the masses the art of our new life. ${ }^{68}$

Malevich stresses that it is the artist-painters who are leading creative research in the field of film. Eisenstein and Vertov, the Wanderers of cinema, are yet to undergo the evolutionary development that the artists-painters already did, transforming their artistic styles from cézannism to Cubism, Futurism, and Suprematism. Hans Richter, who arrived at the experimentation with film form through his work on the dynamic possibilities of scroll paintings, was an ideal candidate for realizing Malevich's aspirations to use cinema as a vehicle for disseminating his Suprematist worldview.

Towards the end of the 1920s, Malevich was losing the support of the Soviet party leaders who felt increasingly more suspicious of any artistic expression ignorant of the State's rhetoric. Malevich was eager to meet with the artists in the West, who, too, worked on developing a new formal language. In 1927, Malevich went to Berlin, his only visit to Europe. The events of this visit can be pieced together from the recollections of those involved. In his memoirs, Richter admits that when in 1965 he was asked to speak of his film collaboration with Malevich — the material was being collected by Werner Haftmann who, at the time, was working on the book about Malevich-his memories were sparse. Richter became curious and with the help of Hans von Riesen, whose brother acted as an interpreter between him and Malevich, Richter, to some degree, reconstructed the events of the past. ${ }^{69}$

In Richter's account, Herr von Riesen, whom Richter did not know, phoned him to announce that Malevich, whose work Richter admired, was to pay a visit. The reason for this 
visit was a proposition to create an abstract film outlining the development of Suprematist forms - a project that was to make Suprematist philosophy accessible to a larger audience. Since Malevich did not speak German, and Richter did not speak Russian, von Riesen, who was originally from Russia and was fluent in Russian, served as an interpreter between the two. ${ }^{70}$ Herr von Riesen also prepared a German translation of Malevich's film script, which in its original language was titled “Художественно-научный фильм 'Живопись и проблемы архитектурного приближения новой классической архитектурной системы”" (Hudozhestvenno-nauchnyj fil'm “Zhivopis' i problemy arhitekturnogo priblizhenija novoj klassicheskoj arhitekturnoj sistemy, Artistic and Scientific Film—Painting and Architectural Concerns-Approaching the New Plastic Architectural System"). The film was never completed, even though Richter and cinematographer Arnold Eagle invested effort in its development in 1970. The project was harder than Richter anticipated: too much time passed since its inception and Richter's own abstract cinematic ideas first expressed in his Rhythmus films started to merge with those of Malevich, creating an authorship dilemma. ${ }^{71}$ Shatskikh remarks that Richter and Eagle consulted a noted film historian Annette Michelson to shed light on whether the version of the film they were creating aligned with Malevich's original vision. ${ }^{72}$

Richter noted that the film was not the only reason Malevich came to Berlin. The latter wanted to find a way for his legacy to survive the Soviet regime that recently announced Socialist Realism as the official aesthetic. ${ }^{73}$ Prior to his arrival to Berlin and his subsequent plans to have Richter animate the evolution of Suprematism, Malevich did attempt to realize his film script on Russian soil. In his letter to N.M. Suetin and B.T. Vorobiev, Malevich writes:

Николай Михайлович и Василий Тимофеевич. Очевидно фильма Супрематическая пройдет и к вам приедет мультипликаторы и еще засъемщики. Нужно чтобы Вы, Николай Михайлович, приготовились т.е. показать как организуются супрематические элементы в объемы и какие можно сделать из них архитектоники. 
Нужно чтобы Хидекель сделал архитектурный план, если не успеет, то у Петина пусть возьмет свой снимок для дачи засъемщикам.

Нужно показать все развитие объемного Супрематизма по ощущениям аэровидного, динамического, статического, готического.

Привет всем провожавшим меня, в понедельник уезжаю. Жду в Варшаву писем побольше.

Пишите все. Очень жалею, что стенгазеты не взял.

Все стали сулить мне блага здесь.

До свидания.

КМалевич.

Nikolai Mikhailovich and Vasily Timofeevich.

It seems that the Suprematist film will pass and animators and camera operators will arrive to you. It is necessary that you, Nikolai Mikhailovich, be prepared, i.e. show how suprematist elements are organized into volumes and what kind of architectonics can be made of them.

It is necessary that Hidekel made an architectural plan, if he does not have time, then let him take his picture from Petin to give to the camera operators.

It is necessary to show the entire development of volumetric Suprematism regarding the sensations of aerolike, dynamic, static, gothic.

Hello to everyone seeing me off, I'm leaving on Monday. I am waiting for lots of letters to Warsaw.

Write all. I am very sorry that I did not take the wall newspapers.

Everyone began to promise me all the good here.

Goodbye.

KMalevich. $^{74}$

This letter, written in Moscow, sometime between 21 and 28 February 1927, provides

instructions to Malevich's colleagues on how to prepare for the meeting with the animators who are to work on the Suprematist film. It can be inferred that Malevich's cinematic project has been brewing long enough for the artist to arrange such a meeting. Little evidence exists regarding the precise date of when Malevich wrote the script, however. Nonetheless, we can be certain that Malevich engaged in the discussions and preparations for the film's executions in advance of his Berlin visit, which took place after his trip to Warsaw mentioned in Malevich's letter. During the aggressive onset of Socialist Realism in the Soviet Union, Malevich was not able to find any filmmakers interested in creating a non-objective animated film.

Malevich came to Berlin not only to meet with Richter but to also exhibit his work, publish some of his theoretical essays, and to visit the Bauhaus in Dessau. German architect Hugo Häring made it possible for Malevich to showcase his paintings at the annual Great Berlin Art Exhibition that took place from 7 May to 30 September 1927. Malevich's major two-part 
essay "The World as Non-objectivity" was published as a book in the series Bauhausbücher, edition 11 in Munich, in 1927 (edited by Walter Gropius and Lazlo Moholy-Nagy). Even though the artist's tour of the Bauhaus was unsuccessful - the renowned art school closed for a spring break a day before Malevich's attempted visit—Malevich enjoyed a brief period of creative camaraderie during his stays in Warsaw and Berlin. ${ }^{75}$

In the end of May 1927, at the request of Soviet authorities Malevich was asked to return to Leningrad, abruptly ending his Berlin visit. Upon his return, the artist was imprisoned and questioned by the police. ${ }^{76}$ Malevich's paintings were cared for by a group of people among whom were Richter, his brother-in-law Udo Rukser, an architect Hugo Häring, and collector Alexander Dorner. Historical events that followed displaced from Germany all but Hugo Häring: Richter was working on an anti-Nazi film in the Soviet Union from 1931 to 1933, Rukser emigrated to Chile, while Dorner- to the United States. ${ }^{77}$ Häring kept the paintings safe, however, and was able to sell them to the Stedelijk Museum in Amsterdam, where they can be found on display today. ${ }^{78}$

Malevich's brief meeting with Hans Richter in Berlin was followed by another passing encounter in $1932 .{ }^{79}$ While Richter was working on the anti-Nazi film Metall, he visited Malevich in Leningrad. The two were never left alone, always being accompanied by Soviet officials, and couldn't speak of their plans to collaborate on a cinematic work. Neither could they discuss a potential exhibition of Malevich's paintings in Vienna and other European cities. Malevich and Richter were able to converse on the harmless topic of colour in cinema during Richter's visit. ${ }^{5}$ Shortly after, in 1935, Malevich passed away. In 1965, Richter received a postcard from Malevich, which was sent from Leningrad in 1928. In this postcard, Malevich

\footnotetext{
${ }^{5}$ Interestingly, Malevich envisioned the invention of colour film prior to its realization and indicated how colour was to be used in his film script.
} 
inquired why Richter did not keep in touch. It was obvious that the former artist felt alienation and misery cut off from the hopes to realize his aspirations to transform the world in the image of Suprematism. ${ }^{80}$

The sense of doom that surrounds Malevich's script is further amplified if we take into account that when Malevich contacted Richter in 1927, the filmmaker had lost interest in the purely abstract cinema that inspired Malevich. In Filmstudie (1925-1926) and Vormittagsspuk (1927-1928), Richter explores the dichotomy between the subject and object. In the latter film, objects revolt against their subservience to human beings. This short-lived reversal of the masterslave relationship is restored to the habitual dominance of humans over objects in the film's finale.$^{81}$ Film scholars often attribute this period of Richter's artistic activity to the shift in Richter's interests towards socially concerned cinema. ${ }^{82}$ Indeed, by 1932, when Richter visited Malevich in Leningrad, his ideas on film underwent a complete transformation. In his book The Struggle for the Film, written in the 1930s in Switzerland, Richter described the growing sense of social responsibility that motivated him to create cinema that would speak to the everyday reality of the working people and provide them with cinematic experiences that instead of serving as meaningless distractions from the difficulties of life would "shape genuine emotions, thoughts and ideas.. ${ }^{\prime 33}$ Richter's later films are far removed aesthetically and philosophically from the Rhythmus films admired by Malevich.

Nonetheless, the earlier period of Richter's work is remarkably close to Malevich's. To begin with, both artists experimented with the surface and not a line, as did Viking Eggeling or Wassily Kandinsky. They also arrived at experimentation and theorization of film through painting. In his post-Dada years, Richter was engaged in a fruitful collaboration with a Swedish artist and filmmaker, Viking Eggeling, who lived and worked with Richter at the latter's parents' 
house in Klein-Kölzig, from 1919 to 1921. In 1919, the two artists produced their first scroll paintings: Eggeling's was called Horizontal-Vertikal-Messe and Richter's—Präludium. One year later, prompted by the sense of motion implicated in the scrolls, Richter and Eggeling animated their rolled paintings and created their first abstract films titled Rhythmus 21 and Diagonal Symphonie, respectively. ${ }^{84}$ Malevich's static work, too, contained a predisposition for movement. According to Margarita Tupitsyn, Malevich arranged his canvases in a celluloid-strip-like manner as early as 1915 . The paintings displayed at the 0.10 exhibition were placed in agreement with vertical rather than horizontal alignment, an unconventional hanging style that could create an association with a filmstrip in which individual frames were Suprematist paintings. Moreover, the absence of texture on the canvas' surfaces approximates the effects of mechanical reproduction of contact printing, making Malevich's paintings appear more like film frames. Lack of texture also eliminates the need to observe the paintings from a close range, creating favourable conditions for viewing the display from afar and thus being able to perceive the celluloid-strip effect of Malevich's exhibiting method. ${ }^{85}$ There is however a significant difference between Malevich's early Suprematist paintings' display and Richter's scroll paintings: the former's paintings were observed all at once, allowing to perceive the total unity the artist sought the knowledge of, while the latter's paintings were structured in a way that provided access to images in succession. Thus, it is possible to state that Richter's work possessed more cinematic qualities than Malevich's did - a possible reason for Malevich's seeking the creative assistance of Richter instead of attempting to realize his film script on his own.

Richter and Eggeling's scroll paintings were inspired by what Eggeling called Generalbaß der Malerei - a theory based on a musical concept of Generalbaß, a German word 
for "thoroughbass" or "figured bass." 86 This term was closely associated with the concept of basso continuo, a strong bass line performed on a keyboard and often supported by cello or bass, providing a harmonic foundation. ${ }^{87}$ Common in Baroque music from 1600 to 1750 , basso continuo was written in a way that required skill in interpretation and provided room for a creative rendition of the bass line ${ }^{88}$ Goethe used the term Generalba $\beta$ to describe a method of creative treatment of a musical composition characterized by freedom of interpretation while being guided by a set of rules. Richter and Eggeling's Generalbaß der Malerei was a response to Goethe 1807 accusation of painting's lacking Generalbaß ${ }^{89}$ Here is how Richter describes Eggeling's engagement with the project of developing the general rules of painting:

Eggeling's dynamics of counterpoint, which he called Generalbaß der Malerei, embraced generously and without discrimination every possible relationship between forms, including that of the horizontal to the vertical. His approach, methodical to the degree of being scientific, led him to the analytical study of the behaviour of elements of form under different conditions. He tried to discover which 'expressions a form would and could take under the various influences of 'opposites': little against big, light against dark, one against many, top against bottom, and so forth. ${ }^{90}$

Richter's description of an almost scientific approach to studying the "behaviour of elements of form under different conditions" is in striking similarity to Malevich's bacteriological investigation of the behaviour of artistic cultures under the influence of various infectious artistic elements (see chapter "Malevich and Energy"). Malevich’s Science of Artistic Culture, too, was, to a degree, inspired by the methods and language of science and aspired for the precision of results. There is another striking parallel development in the direction of the creative investigations undertaken by Richter, Eggeling, and Malevich: interest in conflicts/contrasts between opposing elements as a fundamental guiding principle of a work's structure. Dialectics discussed earlier in relation to Eisenstein, whom, Richter revered and cast in one of his films titled Everyday (1929), is taking the central stage of our discussion yet again.

Before Richter met Eggeling, he was experimenting with positive and negative space. A musician Ferruccio Busoni with whom Richter shared his ideas during an occasional meeting, 
recommended Richter study musical counterpoint. In 1922, with the assistance of Werner Graeff, Richter worked on a project titled Fuge in Rot and Grün (Fugue in Red and Green). Creating dynamic art that overcame objective representation by finding its inspiration in musical form that did not derive from visible reality developed into a practice known as Absolute Cinema, with the principle figures being Richter, Eggeling, Walther Ruttman, and Oskar Fischinger. ${ }^{691}$ The language of music was fundamentally important for Absolute Cinema's filmmakers and helped Richter develop his own visual vocabulary. ${ }^{92}$ Richter writes:

Trying to translate that idea of polarity (in music and form) from music to painting, I began to orchestrate very simple positive-negative relationships of surfaces, black against white, up against down, etc. [...] Repetitions of the same element, distributed on the surface in various places with smaller and greater variations, led to a kind of musical relationship between form complexes and a clearer composition of the whole. ${ }^{93}$

This passage alludes to Richter's interest in synesthesia, as applying musical theories to visual form requires an ability to perceive correspondences between sound and image. It also elucidates how fundamentally important the concept of polarity, so reminiscent of the contrasts, which guided Malevich and Eisenstein's works, is for Richter. A dialectical approach to art making entailed creating perceptual conditions in which the juxtaposition of contrasting elements resulted in their synthesis and the emergence of new aesthetic elements. In their reliance on incorporating contrasting elements in their work, the aspirations of Malevich, Eisenstein, and Richter coalesced: the artists sought to produce and not reproduce reality. Richter identifies the creation of a new cinematic reality as the main aesthetic problem in film. In his later 1955 essay "The Film as an Original Art Form," Richter writes:

\footnotetext{
${ }^{6}$ The movement's most important works were screened at the matinee organized by the Berliner Novembergruppe. The screening titled Der absolute Film took place in the Kurfürstendamm UFA (Universum Film Aktiengesellschaft) film theatre in Berlin, in 1925. In the programme were Richter's and Eggeling's works that were truly inspired by musical form but also Fernand Léger's Ballet mécanique that explored relations between figuration and abstraction, among other themes. Some writers and thinkers began to think that it was Léger's film that was more truly cinematic. It could be that Richter's venture into figurative work was in part encouraged by Léger's cinematic experiments.
} 
The main aesthetic problem in the movies, which were invented for reproduction (of movement) is, paradoxically, the overcoming of reproduction. In other words, the question is: to what degree is the camera (film, colour, sound, etc.) developed and used to reproduce (any object which appears before the lens) or to produce (sensations not possible in any other art medium)? ... In the words of Pudovkin: "What is a work of art before it comes in front of the camera, such as acting, staging, or the novel is not a work of art on the screen". Even to the sincere lover of the film in its present form it must seem that the film is overwhelmingly used for keeping records of creative achievements: of plays, actors, novels, or just plain nature. $^{94}$

Writing as late as he did, Richter preserved the convictions of his youth: the demand for creative cinematic production to be a transformation of what is in front of the camera lens and not its truthful copy speaks to the artist's roots in the early-twentieth-century transformationalism strain of philosophy of art discussed in this chapter. Malevich's 1918 statement is in unison with

Richter's:

Сила мирового большого творчества лежит в нас, а потому нормально художник должен творить, ибо он мировая сила, он хранитель ее, должен идти наряду с природой к изменению, вернее, выходить из оболочки перехода в другую, только живую форму, ибо его дело - дело творения, а творчество есть жизнь. И ненормально, когда художник копирует природу, ибо живые формы, переданные на холст или страницу, уподобляются манекену или чучелу, набитому соломой.

Как бы ни подражал художник, его произведения будут мертвы, но когда он найдет форму новую и введет ее в природу - она будет жизнью и будет правдою. Тогда не будет поговоркою, что искусство есть ложь.

Поэтому художник, поэт, музыкант должны быть чуткими, чтобы услышать колебание творческих форм и видеть внутри себя их очертание и передать в реальную жизнь.

The power of grand, worldly creativity lies within us, and therefore, normally, an artist must create, because he is a world force, he is its keeper, must go along with nature towards change, or rather, leave the transition shell for another, living form, for his work is creation, and creativity is life. And it is not normal when an artist copies nature, for living forms transferred to a canvas or a page are likened to a mannequin or a scarecrow stuffed with straw.

No matter how well an artist imitates, his works will be dead, but when he finds a new form and introduces it into nature, it will be life and truth. Then there will be no more saying that art is a lie.

Therefore, an artist, a poet, a musician must be sensitive in order to hear the fluctuation of creative forms and see their outline within themselves and introduce them into real life. ${ }^{95}$

It is apparent that within their individual art practices Malevich and Richter (and Eisenstein)

confronted fundamentally the same problem of creating new aesthetic elements that were to join

the reality of already existing sensations.

In Richter, Malevich saw the filmmaker capable of realizing his Suprematist film script.

In many ways, the direction of Richter's cinematic experimentations prior to 1927 fulfilled

Malevich's expectations of what a filmmaker should be focused on: creating new cinematic 
realities, non-objective worlds, where forms are rhythmically transformed one into the other. If only history were a bit more generous, the collaboration between these artists could have been truly fruitful.

\section{Conclusions:}

Even though Malevich never created cinematic works, cinema influenced this artist's worldview. In the 1910s, Malevich's relationship with film was one-directional—-the artist was absorbing the excitement around cinema, mostly through his exposure to the ideas relevant to the culture of film, such as dynamism, and through the reception of cinema via other media, such as Symbolist literature. The 1920s were marked by the artist's devoted engagement with film theory, which, in agreement with Malevich's philosophy, was guided by the same principles as his science of artistic culture was - in accordance with the final stage of the evolution of visual forms, film should be non-objective. Through the artist's friendship with Eisenstein, Malevich's dialectical approach to art making flourished: forming art works through the engagement of contrasting elements that create conflicts/contrasts became especially pronounced in Malevich's art and writings. Malevich's intellectual engagement with film reached its climax in 1927, upon the artist's visit to Berlin, where his meeting with Richter left the Russian artist in anticipation of the realization of his cinematic plans. Malevich invested his hopes for Suprematism in film and in Richter: cinema's ability to communicate ideas to a wide range of audience was to make Suprematism an internationally known art system capable of restructuring society to the desired state of the freed no-thing. Unfortunately, the artist's sense of optimism for the future of his legacy was short-lived. 
${ }^{1}$ Bruce R. Elder, Harmony and Dissent: Film and Avant-garde Art Movements in the Early Twentieth Century (Waterloo, Ont.: Wilfrid Laurier University Press, 2008), p. x.

${ }^{2}$ Yuri Tsivian, Early Cinema in Russia and Its Cultural Reception (London: Routledge, 2015), 12.

${ }^{3}$ R. Bruce Elder, Cubism and Futurism: Spiritual Machines and the Cinematic Effect (Waterloo, Ontario: Wilfrid Laurier University Press, 2018), 420.

${ }^{4}$ Ibid.

5 Ibid., 422.

${ }^{6}$ Ibid.

${ }^{7}$ Ibid., 423.

${ }^{8}$ Yuri Tsivian, Early Cinema in Russia and Its Cultural Reception, 5.

${ }^{9}$ Ibid., 8.

${ }^{10}$ Z. N. Gippius, Poslednie Zhelaniia: Povesti, Rasskazy, Ocherki, compiled by M. V. Gekhtman and T. F. Prokopov (Moscow: Intelvak, 2006), 629 (translation mine).

${ }^{11}$ Kazimir Malevich, "Our Time is the Age of Analysis..." [1921], in Sobranie sochinenii v piati tomakh [Collected Works in Five Volumes] (Moscow: Gileia, 1995-2004), vol. 2, 30 (translation mine).

${ }^{12}$ Yuri Tsivian, Early Cinema in Russia and Its Cultural Reception (London: Routledge, 2015), 8.

${ }^{13}$ Denise Jeanne Youngblood, Soviet Cinema in the Silent Era, 1918-1935 (Austin: University of Texas Press, 1991), 13.

14 Anna Lawton, The Red Screen: Politics, Society, Art in Soviet Cinema (London: Routledge, 1992), 28.

15 Ibid., 57.

16 Ibid.

${ }^{17}$ As quoted in Anna Lawton, The Red Screen: Politics, Society, Art in Soviet Cinema, 58-59.

18 Anna Lawton, The Red Screen: Politics, Society, Art in Soviet Cinema (London: Routledge, 1992), 59. 
${ }^{19}$ Alastair Kocho-Williams, Russia's International Relations in the Twentieth Century (London: Routledge, 2013), 44.

${ }^{20}$ Ibid.

${ }^{21}$ Anna Lawton, The Red Screen: Politics, Society, Art in Soviet Cinema (London: Routledge, 1992), 34-35.

22 As quoted in Alexandra Shatskikh, "Malevich and Film," The Burlington Magazine 135, no. 1084 (July 1993): 470.

${ }^{23}$ Ibid.

24 These ideas are outlined in Kazimir Malevich, "Introduction to the Theory of the Additional Element in Painting" [1923], in Sobranie sochinenii v piati tomakh [Collected Works in Five Volumes] (Moscow: Gileia, 1995-2004), vol. 2, 60-96.

${ }^{25}$ Kazimir Malevich, “On Developers: Posters” [1925], in Sobranie sochinenii v piati tomakh [Collected Works in Five Volumes] (Moscow: Gileia, 1995-2004), vol.1, 284 (translation mine).

${ }^{26}$ Kazimir Malevich, "From Cubism and Futurism to Suprematism: New Realism" [1915], in Sobranie sochinenii v piati tomakh [Collected Works in Five Volumes] (Moscow: Gileia, 19952004), vol.1, 42 (translation mine).

${ }^{27}$ Clive Bell, Art (London: Chatto and Windus, 1928), 58.

${ }^{28}$ Ezra Pound, "A Stray Document," in Make it New: Essays by Ezra Pound (London: Faber and Faber Limited, 1934), 339 (emphasis of the author.)

${ }^{29}$ Kazimir Malevich, "And Faces Rejoice on the Screens: In Order of Discussion” [1925], in Sobranie sochinenii v piati tomakh [Collected Works in Five Volumes] (Moscow: Gileia, 19952004), vol.1, 290 (translation mine).

${ }^{30}$ Sergei Eisenstein, "Sergei Eisenstein," in Izbrannye proizvedenija v shesti tomakh [Selected Writings in Six Volumes], ed. S. I. Yutkevitch (Moscow: Iskusstvo, 1964), vol. 1, 86.

${ }^{31}$ Kazimir Malevich, “And Faces Rejoice on the Screens: In Order of Discussion” [1925], in Sobranie sochinenii v piati tomakh [Collected Works in Five Volumes] (Moscow: Gileia, 19952004), vol.1, 289 (translation mine).

${ }^{32}$ R. Bruce Elder, "Eisenstein, My Contemporary (review essay)," Canadian Journal of Film Studies 4, no. 2 (Fall, 1995): 35. 
33 Ibid.

${ }^{34}$ Kazimir Malevich, "Suprematism as Pure Knowledge" [1922], in Sobranie sochinenii v piati tomakh [Collected Works in Five Volumes] (Moscow: Gileia, 1995-2004), vol.3, 90 (translation mine).

${ }^{35}$ R. Bruce Elder, "Eisenstein, My Contemporary,” 36.

36 Ibid., 37.

${ }^{37}$ Ibid., 41.

${ }^{38}$ Sergei Eisenstein, Montazh, ed. N. I. Kleĭman (Moskva: Muzeĭ Kino, 2000), 492.

${ }^{39}$ Ibid., 520 (translation mine, emphases of the author).

${ }^{40}$ Ibid., 498 (translation mine, emphases of the author).

${ }^{41}$ Kazimir Malevich, "Introduction to the Theory of the Additional Element in Painting" [1923], in Sobranie sochinenii v piati tomakh [Collected Works in Five Volumes] (Moscow: Gileia, 1995-2004), vol. 2, 72 (translation mine).

42 Kazimir Malevich, "On New Systems in Art” [1919], in Sobranie sochinenii v piati tomakh [Collected Works in Five Volumes] (Moscow: Gileia, 1995-2004), vol. 1, 157 (translation mine).

${ }^{43}$ Kazimir Malevich, “And Faces Rejoice on the Screens: In Order of Discussion” [1925], in Sobranie sochinenii v piati tomakh [Collected Works in Five Volumes] (Moscow: Gileia, 19952004), vol.1, 293-294 (translation mine).

${ }^{44}$ Sergei Eisenstein, Montazh (Moskva: Muzeĭ Kino, 2000), 514.

${ }^{45}$ Charlotte Douglas, "Evolution and the Biological Metaphor in Modern Russian Art," Art Journal 44, no. 2 (1984): 153.

${ }^{46} \mathrm{R}$ Bruce Elder, Harmony and Dissent: Film and Avant-garde Art Movements in the Early Twentieth Century (Waterloo, Ont.: Wilfrid Laurier UP, 2008), 289.

${ }^{47}$ R. Bruce Elder, "Ejzenstejn, Symbolisme and the Occult," in Filmbuilding. Proceedings of Filmbuilding (published as a CD ROM), Ryerson University, Toronto, 4.

${ }^{48}$ Ibid., 5.

${ }^{49}$ R. Bruce Elder, "Ejzenstejn, Symbolisme and the Occult," 9. 
${ }^{50}$ Ibid., also in S. G. Semenova's introduction to Nikolaĩ Fedorovich Fedorov, Sochineniia (Moskva: Mysl', 1982), 48.

${ }^{51}$ As quoted in S. G. Semenova's introduction to Nikolaĭ Fedorovich Fedorov, Sochineniia, Moskva: Mysl', 47 (translation mine, emphasis of the author).

${ }^{52}$ Khardzhiev-Chaga Collection, Document H_0759, Stedelijk Museum Amsterdam, 3 (translation mine).

${ }^{53}$ R. Bruce Elder, "Ejzenstejn, Symbolisme and the Occult," 12.

${ }^{54}$ Nikolaĭ Fedorovich Fedorov and S. G. Semenova, Sochineniīa (Moskva: Mysl’, 1982), 564.

${ }^{55}$ As quoted in R. Bruce Elder, "Ejzenstejn, Symbolisme and the Occult," 13-14.

${ }^{56}$ Andreï Bely, "Magija slov" [1909], in Simvolizm Kniga Statej (Moskva: Kulturnaâ Revolûciâ, 2010), 316 (translation mine).

${ }^{57}$ Bruce R Elder, Harmony and Dissent: Film and Avant-garde Art Movements in the Early Twentieth Century, 302.

${ }^{58}$ L. A. Kolobaeva, Russkiü simvolizm (Moskva: Izd-vo Moskovskogo universiteta, 2000), 20.

${ }^{59}$ Kazimir Malevich, "Introduction to the Theory of the Additional Element in Painting" [1923], in Sobranie sochinenii v piati tomakh [Collected Works in Five Volumes] (Moscow: Gileia, 19952004), vol.2, 78-79 (translation mine).

${ }^{60}$ Sergei Eisenstein, Montazh, 381.

${ }^{61}$ Ibid., 386 (emphasis of the author).

${ }^{62}$ Sergei Eisenstein, “Cvet,"in Izbrannye proizvedenija v shesti tomakh [Selected Writings in Six Volumes] (Moscow: Iskusstvo, 1964), vol. 1, 519 (translation mine).

${ }^{63}$ Hans Richter, Encounters from Dada till Today (Munich: Prestel, 2013), Kindle Edition, Location 641 of 2717.

${ }^{64}$ As quoted in R. Bruce Elder, "Hans Richter and Viking Eggeling: The Dream of Universal Language and the Birth of The Absolute Film," in Avant-garde Film, eds. Alexander Graf and Dietrich Scheunemann (New York: Rodopi, 2007), 11.

${ }^{65}$ Kazimir Malevich, "Letters: K. S. Malevich to M. O. Gershenzon (1918-1924)," in Sobranie sochinenii v piati tomakh [Collected Works in Five Volumes] (Moscow: Gileia, 1995-2004), vol. 3, 340 (translation mine). 
${ }^{66}$ Kazimir Malevich, "From Cubism to Suprematism: New Painterly Realism [1915], in Sobranie sochinenii v piati tomakh [Collected Works in Five Volumes] (Moscow: Gileia, 19952004), vol. 1, 27 (translation of the image title is mine).

${ }^{67}$ Kazimir Malevich, "Suprematism. From 'The Catalog of the Tenth State Exhibition. Nonobjective Creation and Suprematism"" [1919], in Sobranie sochinenii v piati tomakh [Collected Works in Five Volumes] (Moscow: Gileia, 1995-2004), vol.1, 150 (translation mine).

${ }^{68}$ As quoted in Timothy O. Benson and Aleksandra Shatskikh, "Malevich and Richter: An Indeterminate Encounter," October 143 (2013): 67.

${ }^{69}$ Hans Richter, Encounters from Dada till Today, Location 648 of 2717.

70 Ibid.

${ }^{71}$ Ibid., Location 726 of 2717.

72 Timothy O. Benson and Aleksandra Shatskikh, "Malevich and Richter: An Indeterminate Encounter," 66.

${ }^{73}$ Hans Richter, Encounters from Dada till Today, Location 726 of 2717.

${ }^{74}$ Kazimir Malevich, "Letter from Malevich to N. M. Suetin and V. T. Vorob'ev [Sometime between 21 and 28 February 1927, Moscow]," in Malevich o Sebe, Sovremenniki o Maleviche: Pis'ma, Dokumenty, Vospominaniia, Kritika: V 2-kh Tomakh, eds. I.A. Vakar and T. N. Mikhienko (Moskva: RA, 2004), vol. 1, 184.

75 Ibid., vol 2, 373 (Hans von Risen. Malevich in Berlin)

${ }^{76}$ Ibid., 374.

${ }^{77}$ Hans Richter, Encounters from Dada till Today, Location 738 of 2717.

${ }^{78}$ Ibid., Location 761 of 2717.

${ }^{79}$ Ibid., Location 750 of 2717.

${ }^{80}$ Ibid.

${ }^{81}$ Hans Richter, Dada: Art and Anti-art: With 188 Illustrations (London: Thames \& Hudson, 1997), 198.

${ }^{82}$ Mark Purves and Rob McFarland, "Biographie: Hans Richter," in Hans Richters Rhythmus 21: Schlüsselfilm Der Moderne (Würzburg: Königshausen \& Neumann, 2012), 29. 
${ }^{83}$ Hans Richter, The Struggle for the Film (New York: St. Martin's Press, 1986), 164.

${ }^{84}$ Hans Richter, Dada: Art and Anti-art: With 188 Illustrations, 197.

${ }^{85}$ Margarita Tupitsyn, Malevich and Film (New Have: Yale University Press, 2002), 15.

${ }^{86}$ R. Bruce Elder, "Hans Richter and Viking Eggeling: The Dream of Universal Language and the Birth of The Absolute Film," in Avant-garde Film, eds. Alexander Graf and Dietrich Scheunemann (New York: Rodopi, 2007), 28.

${ }^{87}$ Max Wade-Matthews and Wendy Thompson, The Encyclopedia of Music: Instruments of the Orchestra and the Great Composers (London: Natl Book Network, 2005), 288.

${ }^{88}$ R. Bruce Elder, "Hans Richter and Viking Eggeling: The Dream of Universal Language and the Birth of The Absolute Film," 28.

${ }^{89}$ Ibid., 28-29.

${ }^{90}$ As quoted in R. Bruce Elder, "Hans Richter and Viking Eggeling: The Dream of Universal Language and the Birth of The Absolute Film," 18.

${ }^{91}$ Bruce R Elder, Harmony and Dissent: Film and Avant-garde Art Movements in the Early Twentieth Century, 4-5.

92 Mark Purves and Rob McFarland, “Biographie: Hans Richter,” 22.

${ }^{93}$ As quoted in Mark Purves and Rob McFarland, "Biographie: Hans Richter," 22.

${ }^{94}$ As quoted in R. Bruce Elder, "Hans Richter and Viking Eggeling: The Dream of Universal Language and the Birth of The Absolute Film," 1.

${ }^{95}$ Kazimir Malevich, "Turning-Point" [1918], in Sobranie sochinenii v piati tomakh [Collected Works in Five Volumes] (Moscow: Gileia, 1995-2004), vol.1, 105 (translation mine). 


\section{Conclusions}

Each chapter of this dissertation presents accounts in which artists, philosophers, and thinkers, in one form or another, agree that human flourishing will not be possible unless methods of science are renewed through their synthesis with methods, such as intuition, that do not rely on empirical observations. This aspiration to find new balance between reason and intuition, science and spirituality, resulted in experimentation with how scientific ideas are interpreted and applied. One only needs to recall Nikolai Feodorov's utopian belief in science's ability to resurrect the dead and conquer nature. Kazimir Malevich's relationship with science was driven by a similar rationale: the trajectory of the evolution prescribed by the artist's Suprematist philosophy led to the total annihilation of objecthood, achieving a state of unified no-thing - an esoteric plan that to a large degree was inspired by scientific ideas, which helped to form new conceptions of reality.

Scientific advances of the nineteenth and early twentieth century, which, as I argue in this dissertation, influenced Malevich's worldview, support the artist's arguments for the possibility of breaking away with the logic of clearly defined things and objects. Suprematism engaged with ideas about space and time that differed from those that guide our everyday lives. Fourth dimension conceived of as noumenal reality and interpretation of imaginary space as the underbelly of the visible world both pointed towards the existence of spaces where objects lose shape, mass, and duration —attributes of space shared with the total nothingness of Suprematism's final stage of evolution. The conviction that it is possible to create mathematical objects, such as infinities, by naming them, must have stimulated Malevich's confidence that new reality of Suprematism could be constructed by describing it precisely. Suprematism, the art of flight and aviation, strove to leave the stratosphere of Earth and view the world from further 
away than the aeroplanes that stimulated its birth allowed, making space travel a suitable undertaking for Malevich to pursue. Energetic conception of the world aligned with Malevich's project of freeing the energies of colour from the imprisonment of objects. Malevich's art synthesized scientific method and intuitive approach in his Suprematist philosophical system. The artist's ingenuity in weaving together such an extensive array of scientific fields into a coherent philosophical system makes Malevich's work an infinite source of stimulating insight.

While working on my dissertation, I arrived at intriguing new questions that demand my attention. At the moment, I can identify four projects that require a change of focus and therefore a separate treatment. The first project tentatively titled "Contrasts in the Art of the $20^{\text {th }}$ Century" stems from my writings on Malevich's reliance on contrast as a visual device that lays the foundation for the structure of a painting. ${ }^{1}$ Scholars often concentrate on the formal meaning of Malevich's use of contrasts, while leaving unnoticed other, more philosophical applications of the concept that are present in Malevich's work and occupy a much more central place in Suprematism. In fact, in his writings Malevich argues against considering Cubism and Suprematism as formalist strains of art: these visual systems were developed with the purpose of inducing sensations. ${ }^{2}$ In "Malevich and Film," I highlighted that through the use of contrasts Malevich defines creative process dialectically, as a product of synthesis of opposing elements. What I would like to investigate further is Malevich's understanding of contrasts as collisions between fakturas ${ }^{1}$ that generate energy.

\footnotetext{
${ }^{1}$ In the first edition of the Great Soviet Encyclopaedia (1926), faktura is defined as "individual handwriting, "diction," "the manner of the artist, to which technique is subordinated," "the method of applying paint to the surface" in painting and "methods of processing stone" in sculpture (Šmidt, O.Û, Nikolaï Ivanovitch Boukharine, Valerian Vladimirovitch Kuybychev, and Mihail Nikolaevič Pokrovskij. Bol'šaâ sovetskaâ ènciklopediâ. Moskva: Sovetskaâ Ènciklopediâ, 1928, 590).
} 
Painting's ability to create dynamic sensations through contrasts between elements is what Malevich means by the structure of a painting: it is lines of force created by the difference between forms, textures, and colours. Throughout my doctoral studies, I noticed that other early $20^{\text {th }}$-century artists, such as Sergei Eisenstein, Hans Richter, Viking Eggeling, and Fernand Leger, developed their own philosophies of contrasts. I envision "Contrasts in the Art of the $20^{\text {th }}$ Century" as a book that delves into conceptualization of contrasts, to which each of the aforementioned artists and the artists I am yet to discover ascribes. The aim of the book is to not only understand the underlying motivations behind the formation of a specific interpretation of the concept but also to figure out the historical, cultural, and philosophical reasons behind the importance of contrasts in the works of so many influential artists of the $20^{\text {th }}$ century.

The next two projects I will undertake in the nearest future are intimately connected with the dissertation's research, during which I discovered works that discuss a theory that draws an analogy between human organs and technology (organ projection theory): in Organoproekziya (Organ Projection, written in 1917) Pavel Florensky interpreted an earlier work by Ernst Kapp titled Elements of a Philosophy of Technology: On the Evolutionary History of Culture (1877). There is a striking resemblance between organ projection theory and the ideas explicated in Marshall McLuhan's Understanding Media: The Extensions of Man (1964). The common thread, which unites Kapp's, Florensky's, and McLuhan's writings on organ projection theory, proposes that tools are extensions of our bodies, likening "artificial technological creations to naturally grown organs." ${ }^{\prime 3}$ Kapp, Florensky, and McLuhan stress the relationship between the nervous system and its electric extensions. ${ }^{4}$ My new project aims to determine whether in the current electrologic age new media art serves as an aesthetic agent for gaining insight into contradictions that arose from our invention of an exterior nervous system, the electric technology we rely on in 
our daily lives. As a way to test organ projection theory, I will realize Kazimir Malevich's film script, the focus of my doctoral project, using VR technology to create an immersive experience of this artist's film concept.

As discussed above, my delving into the theories of Kazimir Malevich has granted me with three new projects on contrasts in art, organ projection theory, and virtual reality. Working on this dissertation provided a glimpse into the vast field of studies that interrogates the relationships between art, science, technology, and culture. Having experienced gratification from this intellectual adventure fills me with excitement to continue following the trail of questions that I am yet to address. 
${ }^{1}$ Kazimir Malevich, "Introduction to the Theory of the Additional Element in Painting" [1923], in Sobranie sochinenii v piati tomakh [Collected Works in Five Volumes] (Moscow: Gileia, 1995-2004), vol. 2, 76 (translation mine).

${ }^{2}$ Kazimir Malevich, "New Art and the Art of Representation" [1928], in Sobranie sochinenii v piati tomakh [Collected Works in Five Volumes] (Moscow: Gileia, 1995-2004), vol. 2, 168 (translation mine).

${ }^{3}$ Pavel Florensky, "Organ Projection" [1917], in Sobranie sochinenii v chetyreh tomakh [Collected Works in Four Volumes] (Moscow: Mysl', 2000), vol. 3, 402 (translation mine).

${ }^{4}$ Ernst Kapp, Grundlinien einer Philosophie der Technik (Braunschweig: George Westermann, 1877), 139; Pavel Florensky, "Organ Projection," 412; Marshall McLuhan, Understanding Media: The Extensions of Man (Cambridge, MA: MIT Press, 1994), 5. 


\section{Appendix A: Realizing Kazimir Malevich's Unfinished Film Script}

Introduction:

Kazimir Malevich's unfinished 1927 film script titled "Artistic and Scientific Film—Painting and Architectural Concerns-Approaching the New Plastic Architectural System" consists of a short introductory text and a set of instructions partially accompanied by very basic sketches. Malevich's paragonal thinking is expressed in the introductory text, which speaks of the rapid development of visual arts, starting with Impressionism, and identifies painting as the most experimental field of art. More importantly, in this short text the artist determined a paradigmatic shift in painting: two-dimensional surface was expanded into three dimensions, marking an increased interest in the problems of space. Malevich cites Picasso's reliefs as an example of this shift and briefly mentions Constructivists as artists who developed these spatial concerns as a part of their utilitarian program, with which Malevich strongly disagreed. Suprematism, which in Malevich's history of art is the most advanced visual system after Cubism and Futurism, too, evolved from two-dimensional to three-dimensional shapes, his pre-architectural constructions called architectons, such as Alpha (1923) and Beta (1924-1926). The script depicts the development of the Suprematist shapes from the Black Square, the "royal infant" as Malevich called it, to the complexity of architectons. ${ }^{1}$ When I found this script, I became intrigued by why Malevich left it unfinished and how it might be developed. In what follows I offer a possible scenario of the film's ending (involving even higher dimensional forms) grounded in my dissertation's findings. Since Malevich's film script engages with concepts I have investigated in detail in my dissertation, there will be significant overlap in content between the chapters and this essay. Reiterating some of the important themes and highlighting findings that were already 
discussed is necessary for the sake of laying out a coherent argument in regard to the plausibility of the proposed script's ending.

The Reading of the Script:

Close reading of Malevich's writings reveals an erudite man whose intellect was deeply engaged with the latest developments in science and technology. To understand Malevich, we need to keep in mind that early twentieth century was also marked by proliferation of mystical and esoteric beliefs, which surely were manifested in Malevich's work.

Malevich, the Mystic and Malevich, the Scientist have found full expression in his film script, where, I contend, the artist engages with evolutionary theories, fourth-dimensional geometry, and infinite set theory. To arrive at these conclusions, I began by examining the script and reading the instructions left by the artist. It appears that the script is about growth and evolution, for example the circle is a descendant of the square and is achieved through the square's rotation; the script is also concerned with space as the shapes change from flat to those having volume; the script is also about infinity, there is a sense of a logical unfolding in a series that brings to mind set theory, a branch of mathematics that studies infinity (please refer to the transcript of the script and my illustrations of the major stages of the script's development attached at the end of this essay). My next step was to find out what Malevich writes about these concepts, which brings me to the discussion of Malevich's relationship with the concept of evolution.

\section{Evolution:}

In his writings, Malevich stresses that environment is responsible for the style of art being created. Artists are affected by the environment in which they find themselves. The specifics of the environment become crystalized in units, the tiniest elements that change the content of an 
artwork. This is analogous to Charles Darwin's theory of natural selection that states that this or that trait becomes predominant in a species through this species' interaction with its environment. $^{2}$

Malevich calls these tiny particles that affect the way an artwork looks, additional elements. The new environment that brought about changes in Malevich's consciousness that resulted in the development of Suprematism was aviation. Writing almost fifty years prior to Marshall McLuhan's outlining his ideas on the technology of airplanes in Understanding Media: The Extensions of Man (1964), Malevich elaborates on the effects of the technological environment of aviation on human consciousness, paralleling McLuhan's intellectual investigations. ${ }^{1}$

This interest in the effects of technology on the structure of the human mind can be found in Malevich's and McLuhan's analyses of aviation-dynamic electrologic technology that decentralizes, unifies, and extends our bodies, while simultaneously abhorring linear conceptions of time (please refer to the chapter "Malevich and Energy"). Both thinkers noted that the possibility of flight reveals the world from an unusual aerial point of view. Malevich saw this world reflected in the mind as a picture made up of straight lines, while McLuhan maintained that elevation above the ground and dynamism of speed attainable by airplanes made one simultaneously present in any part of the world ("simultaneous touch"). This infinite aerial space

\footnotetext{
${ }^{1}$ The presence of McLuhanate themes in Malevich's work is difficult to ignore and is a recurrent motive in my writings on this artist's oeuvre. For example, both thinkers were intrigued by the influence prevalent technology had on language. In his book Gutenberg Galaxy (1962), McLuhan offers an analysis of how modern man has come to rely on descriptive functions of language to the detriment of poetic ones. McLuhan sketches a trajectory of change that the structure of the human mind underwent, and which was triggered by the development of literacy and, in particular, of the phonetic alphabet. Malevich paid tremendous attention to exploring the interaction of art and science, tracing the outcomes of the split between these worldviews on the segregation of language into descriptive (scientific, static) and poetic (artistic, dynamic) categories. These investigations originated in the artist's union with the Russian Futurists and their experiments with Zaum poetic language, a theme explored in my paper "Resisting Clarity / Highlighting Form: Comparing Vanguard Approaches in Poetry and Programming."
} 
that does not obey the principles of Cartesian geometry and Newtonian physics, as theorized by Malevich and McLuhan, inspired Suprematism.

In his 1927 essay "Introduction to the Theory of the Additional Element in Painting," Malevich illustrates this theory of Suprematism's intimate relationship with its environment by including a didactic illustration titled Окружение, вдохновляющее супрематистов (“действительность”) (Okruzhenie, vdohnovljajushhee suprematistov [“dejstvitel'nost”’], Environment that Inspires Suprematists ["reality"]), which depicts aerial views and photographs of airplanes that indeed bring to mind Suprematist compositions. ${ }^{3}$ Malevich also determined the environment responsible for the evolution of Cubism. Originating in the dynamism of city life, Cubist artworks consist of sickle-shaped curves that are better suited for the depiction of the fragmented objects prevalent in Cubism. On the relationship between the environment and the formation of the additional elements Malevich writes:

The peculiar character of any new environment, exercising its effect upon us, constitutes that "additional element" which brings about a change in the normal relationship between the element of consciousness and that of the subconscious and which, in case of the "professional response," is expressed in a new, unfamiliar technique, in a certain unusual attitude toward nature - in a novel point of view. ${ }^{4}$

As I mentioned in the chapter "Malevich and Energy," these additional elements found in art can enter other artworks through the consciousness of an observer and infect these artworks, altering their content. Malevich calls his investigations into the behaviour of additional elements, The Science of Artistic Culture. ${ }^{2}$ It is important to mention that Malevich relies on the play of words and uses the word "culture" in a dualistic sense, referring to culture as the product of society's intellectual and creative life and culture as a biological term, suggesting cell culture. At the end

\footnotetext{
${ }^{2}$ Note how strongly Malevich's Science of Artistic Culture resonates with Renato Barilli's Science of Culture and Phenomenology of Styles. The additional elements constitute the symbolic order of culture that is in homologous relationship with the material technological order, which for Malevich was not only the new urban environment but more prominently aviation discussed earlier. It is to the study of both the technological and the symbolic orders in art that Malevich and Barilli devoted their analyses of culture.
} 
of the nineteenth and beginning of the twentieth century, Russian art was infused with metaphors pertaining to biology. ${ }^{5}$ At the same time, this period was marked by a sustained interest in the occult and alchemical doctrines. The biological and occult leanings of the artists of this period announced "transformationalism" as the primary artistic force in visual arts. ${ }^{6}$ This development can be witnessed in one of the instructions provided in the film script, which states that the script must "demonstrate the growth of the cell of suprematist square."7

Malevich's essay "Introduction into the Theory of the Additional Element in Painting," the artist's major text on the Science of Artistic Culture, epitomizes the artist's interest in biological concepts and is inspired by Robert Koch's 1882 discovery of Mycobacterium tuberculosis ("палочка Kоха" in Russian or Koch stick/line). To highlight the analogy between his science of art and bacteriology and to explain how an artistic body can be infected with Suprematism, Malevich emphasizes that Suprematism's additional element is Suprematist line, which is identical to the Koch bacillus' shape. ${ }^{8}$

I would like to briefly mention that treating paintings as bodies and painterly elements as bacteria, speaks to the influence of another important intellectual key figure of the turn of the century, Henri Bergson. His Creative Evolution was published in Russia in 1907 and sparked a renewed interest in Darwin's evolutionary theories. Bergson was an extremely important philosopher for Malevich, and his philosophical ideas practically defined the artist's conception of reality. ${ }^{9}$ For Bergson, as for Malevich, reality is an amalgamation of vital elements; he sees everything containing the vital force, élan vital: we can see this in his iconic Black Square, which he thought of as "the embryo of all possibilities" and "the living royal infant." Malevich considered his creations to be living things and as living things they participated in events of life, such as growth and evolution. 
It is important to note that evolutionary and vitalist ideas were widely spread among early twentieth-century artists and thinkers, who felt an urgent need for social renovation and spiritual renewal. Since it was grounded in science, the proposition to apply evolutionary theory for the betterment of society was potent with hope and assurance of success. Among the most outspoken in this regard was an important contemporary of Malevich, George Bernard Shaw, a playwright, critic, and political activist awarded the Nobel Prize in Literature in 1925. Bernard Shaw's play Man and Superman (1902) outlines the author's ideas on the subject of the evolution of humankind with forcefulness and clarity. The underlying principles of the actions suggested by Shaw in this play are in many ways analogous to the course of evolution proposed by Malevich in his Suprematist philosophy: both thinkers call for the complete restructuring of society and abolition of traditions and norms that stale the arrival of the new era of humanity. Shaw expresses his views through John Tanner, a revolutionary pamphleteer, whose work "The Revolutionary's Handbook and Pocket Companion" is an appendix to Man and Superman. In his Handbook, Tanner offers evidence that calls for the urgent need to begin the program of breeding Supermen - a conscious selection of human species for the development of outstanding human beings (Shaw supported eugenics movement and lectured at the Eugenic Education Society). ${ }^{10}$ According to Tanner, all the advancements in society, in its technologies and structures are illusions, "changes from Tweedledum to Tweedledee."11 The only concrete improvements are the results of conscious manipulation of Nature — selective breeding aimed at forcing Life to produce species that satisfy human purpose, such as the development of a racehorse or a new cultivar of apple. ${ }^{12}$ Tanner argues that practicing selective breeding of human species requires an abolition of the foundations on which Western society rests. Among these are the institution of marriage and the idea of property, which often stand on the way of potential couples' successful 
procreation by limiting the genetic pool through segregation based on social class and marital status. In many ways Tanner's prescriptions are as entropic as Malevich's call for the dissolution of objecthood and gaining the knowledge of infinite nothingness. Human society has been bounded by the obligations of marriage and driven by acquisitions of property for most of its history. These institutions define and shape society similarly to Malevich's objects being defined and shaped by the rigid lines of intellectual concepts. Destroying these norms would bring the loss of structure and societal boundaries akin to the objectlessness of the freed no-thing described by Malevich in his writings. The key to achieving these goals lies through evolution.

As I mentioned earlier, Vitalist ideas, which often accompanied the evolutionary strain of thought, captivated the minds of the vanguard artists of the early twentieth century. Italian Futurists, who claimed that stimulated by urban environment their sensibilities evolved to appreciate the speed and roar of the machines, saw the latter as animated by a life force akin to that which, like Bergson's élan vital, breathes life into all forms of being. As R. Bruce Elder states in his book Cubism and Futurism: Spiritual Machines and the Cinematic Effect, Futurists understand machines as entities that possess dual nature: they exist as materials and, at the same time, are imbued with characteristics of intelligent and intuitive life. ${ }^{13}$ In this context of Vitalism being an integral part of the intellectual landscape of his contemporaries, it is not surprising that Malevich saw his Suprematist shapes in a similar vein, as materials and as living beings. If we return to this artist's film script, we can see how the cell of Black Square evolves and morphs into other more complex shapes, as a living growing organism would do. This impetus towards complexity agrees with Darwin's theory of natural selection. Evolution leads to more complex forms of life as a result of the struggle for survival. An analogous progression towards complex forms can be witnessed in the evolution of Malevich's Suprematist vocabulary, allowing a 
proposition that if the script were to continue its development, the forms would gain more complexity in their structure. This developmental trajectory accords with Malevich's prescription to demonstrate "the growth of the cell of suprematist square."

Space:

Now I would like to turn attention toward another theme present in Malevich's film script: space. To understand Malevich's interest in space we need to look into one more theory of evolution popular in Russia at the time: psychic evolution. One of the major proponents of psychic evolution was Russian philosopher and mystic, Pyotr Ouspensky. Ouspensky adopted the ideas of Charles Hinton, a British mathematician whose philosophy is centered on the belief that the evolution of humankind is possible through the evolution of the ability to visualize the fourth dimension. Russian mathematician and esotericist, Pyotr Ouspensky, who was inspired by Hinton's hyperspace mathematics and the latter's enthusiasm regarding the evolutionary advances it would bring, expanded Hinton's theories into an esoteric philosophical system, which promised to transform the world.

As I emphasized throughout my dissertation, Ouspensky’s ideas played a fundamental role in the development of Malevich's Suprematism. I located evidence for this conjecture in the primary and secondary sources, among which the most intellectually exciting finding was the almost verbatim quote of Ouspensky I found in one of Malevich's handwritten documents I had the pleasure to consult at the Khardzhiev-Chaga archive (Stedelijk Museum Amsterdam). The paragraph that the quote appears to have been extracted from belongs to Tertium Organum's chapter VIII, devoted to Ouspensky's theory of the relationship between the evolution of psychic apparatus and perception of higher dimensions. There, Ouspensky states:

We are not yet fully aware of the forms in which the development of human abilities will result. But we can already say that the forms of our consciousness, their modes of expression, continuously evolve and, apart 
from the forms known to us, new ones must be formed. ${ }^{3}$

At the moment, we have three units of psychic life - sensation, representation, concept (and idea), and the fourth unit - the higher intuition - begins to form.

... If we could change our psychic apparatus and see at the same time that the world around us has changed, this would be for us the proof of the dependence of the properties of space on the properties of our consciousness.

For example, if we could add a fourth to the three existing units of psychic life, that is, to make a higher intuition that exists now only in an embryonic form, as certain, precise and acting according to our will as concept - and if in doing so the number of characteristics of space increases, that is, if the space from the three-dimensional becomes four-dimensional, then this would confirm our assumption and prove Kant's idea that the space with its properties is the form of our sensory perception. ${ }^{14}$

Ouspensky proposed a theory, following Kant, that the way we perceive space is dependent on our consciousness, leading him to suggest that for a being whose consciousness relies on sensations only, the world is a one-dimensional line, while for a human, who operates by using three faculties of sensations, perceptions, and conceptions, reality presents itself as a threedimensional Euclidian space. ${ }^{15}$ There is however a fourth faculty, that of intuition or higher logic, which, if acquired, will reveal the world as four-dimensional. This four-dimensional reality is hidden behind the illusory appearance of three dimensions that we are accustomed to perceive as the space we inhabit. Ouspensky based his propositions explicated in his book Tertium Organum on the highly popular text by Hinton titled A New Era of Thought. There, Hinton explained the four-dimensional world by drawing analogies between the worlds with three dimensions passing through a two-dimensional plane. For example, a cube passing through a plane can appear as triangle. Similarly, the three-dimensional world we live in may well be a slice of a four-dimensional world. ${ }^{16}$

So, what was Malevich's position regarding the geometric fourth dimension? Besides quoting Ouspensky, Malevich also created many paintings whose titles indicate the artist's interest in the geometry of higher dimensions. Among these works are: Painterly Realism of a Boy with a Knapsack - Colour Masses in the Fourth Dimension (1915), Painterly Realism of a

\footnotetext{
${ }^{3}$ In English edition of Tertium Organum the part quoted by Malevich is omitted.
} 
Football Player - Colour Masses in the 4th Dimension (1915), Self Portrait in Two Dimensions, Automobile and Lady - Colour Masses in the 4th Dimensions (1915), and Lady - Colour Masses in the Fourth and Second Dimensions (1915). As we can observe, these paintings do not rely on any conventional methods of visualizing the fourth dimension. Why is this so? In "Цветопись" (Tsvetopis', Colour-writing) (1917), Malevich writes:

\begin{abstract}
The colourist stood directly in front of the bare material from which he was to create a two-dimensional or three-dimensional shape (sculpture). (The fourth measure, the movement in time, or the representation in the image of that part of the thing that is hidden, i.e., the fourth side, is the disclosure of all four sides of the thing for a clear conception of it, but at the same time the thing loses its general form, so that the pursuit of finding out the fourth side of the thing does bring one to figuring it out, but destroys the thing, its real existence. I think that the achievement of the fourth dimension with respect to the fourth side of the thing at the expense of others is ridiculous. I am convinced that the fourth measure should be attributed to time... ${ }^{17}$
\end{abstract}

As I established in the chapter "Malevich and the Fourth Dimension," Malevich argued against attempting to represent four-dimensional subject matter, even though he subscribed to Ouspensky's conviction that art is capable of relaying intuitions of hyperspace. This conclusion on behalf of Malevich stems from the artist's practical concerns - it is incredibly difficult to imagine a four-dimensional object, let alone visually arrest its shape on a two-dimensional canvas. It becomes possible to suggest that it is dedication to communication of ideas to the public that prevented Malevich from completing his film script by stating that the next generation of Suprematist shapes should be four-dimensional. After all, Malevich was akin to a missionary, eager to introduce as many people to Suprematist philosophy as possible; his apprehension regarding visual representation of the fourth dimension is understandable. However, now, with the available digital tools it becomes possible to envision Suprematist evolution in higher dimensions, showing that part of a thing that is hidden, its fourth side. And this is exactly what I propose to do when it comes to completing Malevich's film script: create an architecton in four dimensions of space as a way of continuing the evolution of Suprematist shapes that have already undergone the two- and three-dimensional stages of development. 


\section{Infinity:}

The next theme that I would like to discuss in relation to Malevich's script is infinity. From visually analyzing the stages of the script's development where the transformations of the shapes are most obvious, I came to understand that the script explores this concept, so important for Malevich's Suprematist philosophy. I contend that the script resembles an infinite set, where the elements of the set are $\mathrm{n}+1$-dimensional shapes. In mathematics, a set is a collection of distinct objects, considered as an object in its own right. Infinite sets are used to study the concept of infinity. Treating the script as an infinite set whose elements are n+1-dimensional shapes may also explain why Malevich did not finish the script. He may have imagined it being infinite.

Malevich's writings are permeated with the artist's pondering upon the nature of infinity. One might say that infinity is the final stage of Suprematism's evolution. Malevich's artistic development has undergone shifts well documented by the artist himself. His colour Suprematism of the early works transformed into monochrome paintings, among which the 1918-1919 white-on-white paintings are the most representative. In the 1920s, Malevich stated, "that one cannot attain with the brush what can be attained with a pen."18 This was the period when the artist preferred the infinite space of his mind to that of the canvas and devoted himself to writing with unprecedented fervor. Here is what Malevich writes about his white paintings where the figure is disappearing within the ground, signifying endless space of total objectlessness, the infinite abyss:

At the moment, a person's path lies through space; suprematism, the semaphore of colour-in its infinite abyss. The blue colour of the sky is conquered by the suprematist system, it was broken through, and it entered the white as a true real representation of infinity and therefore is free from the colour background of the sky. ${ }^{19}$ 
For Malevich, the evolution of humanity was to take radical steps towards annihilation of form, leading to total objectlessness and rendering meaningless traditional notions of time and space.

The artist associated this stage of evolution with infinity. Malevich explains:

Let us assume that in many thousands or millions of years humanity will attain omniscience, hence, will reach the state of being everywhere. What will this moment be like? There will be nothing to comprehend and nothing to know, and, obviously, there will be nothing to do. The world is open, and its entire being stands in knowledge, the universe in all its greatness and infinity of its creations will move according to its eternal law of motion... Then, the beginning of a new divine inactivity, non-being, disappearance of personhood will arrive, for the humanity will enter into that greatest image of its perfect predestination. ${ }^{20}$

The ultimate state of perfection, according to Malevich's view of human evolution, is to merge with the non-objective endlessness of the infinite. Malevich's radical evolution is directed at the total disintegration of form; his Suprematism aspires to liberate nothing from the confines of objecthood, to become the infinite abyss:

The effect of Suprematism is not constrained by any boundaries of "practical", "purposeful", "conformable" "tasks," or analysis, or synthesis, by any search for genuine or non-genuine artistic aesthetic, it does not serve anything. Everything is in a state of non-objective equality, or zero of weight, it is nothing - the answer to "thing" of society [общежитие]. Moreover, all humanity's efforts through all the expediency, all practical considerations go to the same objectless absolute consciousness, in which it will lose sight of everything.

Suprematism as non-objectivity, as a liberated nothing, is in a sharp contrast with "organizational ideological objecthood." 21

So how does this vision of liberated nothing, this infinite non-objectivity, infinity of all creations that Malevich imagines, correspond to the mathematics of the infinite? To establish these connections, I will re-introduce the concepts of actual infinity and potential infinity. I contend that the space of objectlessness, the infinite abyss that Malevich describes, is reminiscent of the actual infinity, defined as a finite space that has an infinite number of elements; all elements of actual infinity exist simultaneously, making it possible to experience them all at once, as a totality. Aristotle denied existence of the actual infinity, which he considered to be a paradox. ${ }^{22}$ In $2^{\text {nd }}$ century $\mathrm{AD}$, Plotinus identified actual infinity with the boundless nature of God and the concept was reserved for theologians until the $19^{\text {th }}$ century when it became the center of mathematicians' attention with Georg Cantor's establishing set theory. ${ }^{23}$ The actual infinity with 
its endless number of elements reminds of Malevich's vision of the infinite abyss: this is the space in which there are so many things that it becomes impossible to differentiate one from another; it becomes nothing while being everything.

Let's compare the actual infinity with the potential infinity. If actual infinity presupposes finite space, potential infinity requires endless space that unfolds with addition of new things or elements. I think of it as an endless strip of numbers where each number is followed by the next. It is possible to arrest this motion and see a range of numbers, but it is impossible to see the entire strip at once. Elements of a potential infinity exist consecutively over time. The actual infinite is like a black hole or Malevich's Black Square if you wish, where things pile up and are hard to differentiate. The potential infinite is like a ticking clock, where each element is followed by the next, staying clearly defined.

It appears that Malevich's infinite abyss is approaching the definition of actual infinity, which became one of the major topics in mathematics in the middle of the $19^{\text {th }}$ century in the work of Georg Cantor, the founder of set theory. As I mentioned in the chapter "Malevich and Infinity," Malevich's description of the infinite-“I saw myself in space, hidden in dots and bands of colour; there among them I sank into the abyss"24_is surprisingly close to that of

\section{Cantor:}

As to the concept of a set, Dedekind said he regards a set as a pursed sack, a sack that contains certain specific things, but you do not see them and know nothing of them other than that they are specific and present. Some time later, Cantor gave his own idea of a set. He draw himself up to full height, described with his arm a grandiose gesture, and, with inscrutable gaze, breathed: 'I visualize a set as an abyss' ${ }^{25}$

Inspired by his theological concerns, Cantor invented transfinite numbers to speak the language of the infinite, which he associated with God. For Malevich, the concept of infinity was closely related to that of non-objectivity. It promised the possibility of arriving at the stage of 
human evolution, of total unity achieved through elimination of form and atavistic notions of time and space.

\section{Conclusions:}

Now, after briefly elucidating some of the themes in Malevich's script, I would like to take a moment and imagine how the script will unfold if the underlying principles I highlighted take control of its development. If the script satisfies the requirements of evolutionary theory, higherdimensional geometry, and infinite set theory, the set of Malevich's Suprematist shapes will continue to evolve in complexity ad infinitum, increasing in the number of geometric dimensions, so that the four-dimensional architecton will evolve into the five-dimensional architecton, and so on. Eventually, the space of the artwork will become inhabited by the shapes' numerous sides in such a densely populated manner that it will be difficult to differentiate between faces of the figures, let alone comprehend the shapes' geometry. An infinite addition of geometric dimensions will result in the loss of the sense of shapes' outlines, loss of differentiation that will lead to the total non-objectivity, the freed nothing that Suprematism aspires to portray. The artwork's space will gradually be filled until it becomes fully black: liberated nothing will take over the observer. The effect of the loss of differentiation that comes with the increase in geometric dimensions can be illustrated by the image of a cube in $10^{\text {th }}$ dimension (see Figure A.6). As it can be witnessed from this image, the complexity of the shapes reverses itself into its opposite (bringing to mind McLuhan's laws of media)—visual simplicity of a colour field. It is this dual nature of Malevich's art that captivates my intellect and imagination: his work's geometry and structure's elegant simplicity is in a fruitful conflict with the underlying philosophic complexity. 
With the way I want to finish Malevich's script I aspire to reiterate the artist's conviction that there is no empty space- - his axiom so masterfully expressed in the iconic Black Square. The density of the latter work, the darkness of its canvas, can be interpreted as the actual infinite: the existence of infinitely many elements within a limited space. I suggest that the script's evolution is directed at reaching this condition of actual infinity, which, as discussed in the chapter "Malevich and Infinity," the artist associated with nonobjectivity. The Suprematist cell of Black Square, even though, as I contend, already contains within itself the all-and-nothing of infinity, needs to evolve and infinitely grow for the didactic purpose of teaching the public the principles of Suprematist evolution - the intent behind the film. To determine these principles of infinite organic growth directed towards higher-dimensional complexity, I used the deductive method of science: I created a deductive inference of what the future steps of the script could be like. Relying on such method is a conscious decision driven by my aspiration to carry on the creative vision of Malevich, who often employed scientific-like thinking in developing his artistic ideas.

Among other reasons for my conviction that my interpretation of the script's unfolding agrees with Malevich's vision is the script's potential to form a loop; to draw a circle with its narrative instead of a line. The organic logic of evolution outlined here visually brings the growth of Suprematist shapes to the stage where it began: the density of n-dimensional architecton approaches the density of the Black Square, suggesting cyclical development, a loop. From the darkness of the n-dimensional architecton the Black Square can be born again. This cyclical nature of the script's narrative agrees with Malevich's distrust of linear conceptions of time associated with the Newtonian worldview the artist left behind. The disorienting, timeless, objectless space of the final stage of Suprematism's evolution as outlined in my version of the 
script's finale, will approach the space of Malevich's desert discussed in the chapter "Malevich and Mysticism": "White fields are not the fields that frame the black square, but only a sensation of a desert, a sensation of non-existence, in which a variant of a square-shaped form is the first non-objective element of sensation. ${ }^{.26}$ While realizing the film script in its totality is in my future plans, these ideas inspired a Virtual Reality (VR) prototype of a static four-dimensional architecton in a space where the ground is made up of the photographs of paint cracks found on the surfaces of Malevich's paintings—an approach that I used to bring to mind Malevich's philosophic conception of a desert as nonobjectivity. Finally, in terms of my choice of technology, Stereo 3D, which I initially intended to use, and VR are technological tools that through immersion can relay sensations of Suprematist shapes' inhabiting the space of the viewer. Making these shapes a part of the audience's sensorium will take Malevich's project one step further towards restructuring the world in the image of Suprematism. 
${ }^{1}$ Kazimir Malevich, "Artistic and Scientific Film-Painting and Architectural ConcernsApproaching the New Plastic Architectural System" [1927], in Sobranie sochinenii v piati tomakh [Collected Works in Five Volumes] (Moscow: Gileia, 1995-2004), vol. 5, 307-312.

${ }^{2}$ Charles Darwin, Charles Darwin on the Origin of Species: The Illustrated Edition (New York: Sterling, 2008), 8 .

${ }^{3}$ Kazimir Malevich, "Introduction to the Theory of the Additional Element in Painting" [1923], in Sobranie sochinenii v piati tomakh [Collected Works in Five Volumes] (Moscow: Gileia, 1995-2004), vol. 2, 65 (translation of the image title is mine).

${ }^{4}$ Kazimir Malevich, The Non-Objective World (Chicago: Paul Theobald and Company, 1959), 12.

${ }^{5}$ Charlotte Douglas, "Evolution and the Biological Metaphor in Modern Russian Art," Art Journal 44, no. 2 (1984): 153.

${ }^{6}$ R. Bruce Elder, Harmony and Dissent: Film and Avant-garde Art Movements in the Early Twentieth Century (Waterloo, Ont.: Wilfrid Laurier University Press, 2008), 289.

${ }^{7}$ Kazimir Malevich, "Artistic and Scientific Film—Painting and Architectural ConcernsApproaching the New Plastic Architectural System" [1927], 309.

${ }^{8}$ Kazimir Malevich, "Introduction to the Theory of the Additional Element in Painting" [1923], 80.

${ }^{9}$ Hilary L. Fink, Bergson and Russian Modernism: 1900-1930 (Evanston, IL: Northwestern University Press, 1999), 82.

${ }^{10}$ Diane Paul, "Eugenics and the Left," Journal of the History of Ideas 45, no. 4 (1984): 567590 .

${ }^{11}$ George Bernard Shaw, Revolutionist's Handbook and Pocket Companion (Salt Lake City: Project Gutenberg, 2008), Kindle Edition, Location 19 out of 645.

${ }^{12}$ Ibid., Location 18 out of 645.

${ }^{13}$ R. Bruce. Elder, Cubism and Futurism: Spiritual Machines and the Cinematic Effect (Waterloo, Ontario: Wilfrid Laurier University Press, 2018), 379-380.

${ }^{14}$ P. D. Uspenskiĭ, Tertium Organum (Sankt-Peterburg: Trud, 1911), 65-66 (translation mine).

${ }^{15}$ P. D. Uspenskiî, Tertium Organum: The Third Canon of Thought; A Key to the Enigmas of the World, trans. Claude Fayette Bragdon and Nicholas Bessaraboff (New York: Alfred A. Knopf, 1922), 85 . 
${ }^{16}$ Charles Howard Hinton, A New Era of Thought (London: Swan Sonnenschein \& Co., 1888), 98-99.

${ }^{17}$ Kazimir Malevich, "Cvetopis"” [1916-1918], in Sobranie sochinenii v piati tomakh [Collected Works in Five Volumes] (Moscow: Gileia, 1995-2004), vol. 5, 67 (translation mine).

${ }^{18}$ Kazimir Malevich, "Suprematism. 34 drawings" [1920], in Sobranie sochinenii v piati tomakh [Collected Works in Five Volumes] (Moscow: Gileia, 1995-2004), vol. 1, 188 (translation mine).

${ }^{19}$ Kazimir Malevich, "Suprematism. From 'The Catalog of the Tenth State Exhibition. Nonobjective Creation and Suprematism,", in Sobranie sochinenii v piati tomakh [Collected Works in Five Volumes] (Moscow: Gileia, 1995-2004), vol. 1, 150 (translation mine).

${ }^{20}$ Kazimir Malevich, "Laziness - The Real Truth of Humankind" [1921], in Sobranie sochinenii v piati tomakh [Collected Works in Five Volumes] (Moscow: Gileia, 1995-2004), vol. 5, 183 (translation mine).

${ }^{21}$ Ibid., 107.

${ }^{22}$ Michael J. Smith, “Aristotle on the Infinite, Space, and Time," in A Companion to Aristotle (Oxford: Wiley-Blackwell, 2013), 263.

${ }^{23}$ David J. Yount, Plotinus the Platonist: A Comparative Account of Plato and Plotinus' Metaphysics (London: Bloomsbury Academic, 2016), 30.

${ }^{24}$ Marion Ackermann and Isabelle Malz, Kandinsky, Malewitsch, Mondrian: Der weisse Abgrund Unendlichkeit = The Infinite White Abyss (Koln: Snoeck Verlagsgesellschaft mbH, 2014), 251.

${ }^{25}$ R. Thiele, "Georg Cantor (1845-1918)," in Mathematics and the Divine: A Historical Study, ed. Luc Bergmans (Amsterdam: Elsevier Science, 2005), 542.

${ }^{26}$ Kazimir Malevich, “The World as Non-Objectivity: Suprematism,” 109 (translation mine). 
Transcript of Kazimir Malevich's film script "Artistic and Scientific Film - Painting and Architectural Concerns - Approaching the New Plastic Architectural System” (1927)*

1. Black Suprematist square; red Suprematist square; white Suprematist square

2. The movement of the Suprematist square yields the circle in various colors.

3. The circle has its definite place within a limited space: the black circle appears in the center of the limited surface; as it is displaced toward the limit it takes on a green color; and, when even more displacement occurs, a red color; finally, by upward displacement, it becomes white, with the feeling of dynamism.

4. Changes within the circle introduce color changes.

5. Decomposition of the Suprematist square into two white and two black cells: in two corners of the square a lightening begins, becoming pure white. Two corners of the square remain unchanged, black. A new form of quadratic relationship is thus developed.

6. Now a displacement occurs in form no. 5: the upper black square is transformed into a white one, the white into a black one. A new Suprematist element develops, and in the next stage takes on color.

7. Form no. 6 now continues to develop. It topples from the vertical to the horizontal position: Thus the black surface (a) shifts its position until separate Suprematist elements are formed, which become the basis for the formation of a whole system of relations.

8. Out of these elements, the Suprematist straight lines, develop now new basic forms, first the cross-form.

9. The cross-forms begin to develop into structures with dynamic feeling. In this phase of the development of the cross-form element, an expansion of the Suprematist straight lines occurs, with the red element becoming thinner below than it is above. The same occurs in the case of the black element. With expansion, the straight lines can be decomposed into single small members, or they can remain in the cross-form combinations, thus arriving in a diagonal position.

10. Here we see the element (a) contracting again into a square, two further elements in the colony make the cross-form, from the rotation of which derives the circle, thus making a new figure.

11. Here we have one of the possible kinds of colony of Suprematist elements.

12. Now we see the development of a Suprematist straight line into a spatial structure.

13. Form no. 12 develops according to the same principle as do the elements on the flat surface, that is, it is decomposed and enters into combination with other elements. As the elements move, cubes and similar forms develop, expanding and forming elements of different sizes.

14. The forms developed in this way constitute architectonic fragments.

15. Out of the architectonic fragments issue architectonic systems.

16. These systems present the problems of the new architecture.

* Extracted from Hans Richter's Encounters from Dada till Today. Munich: Prestel, 2013, Kindle Edition. 

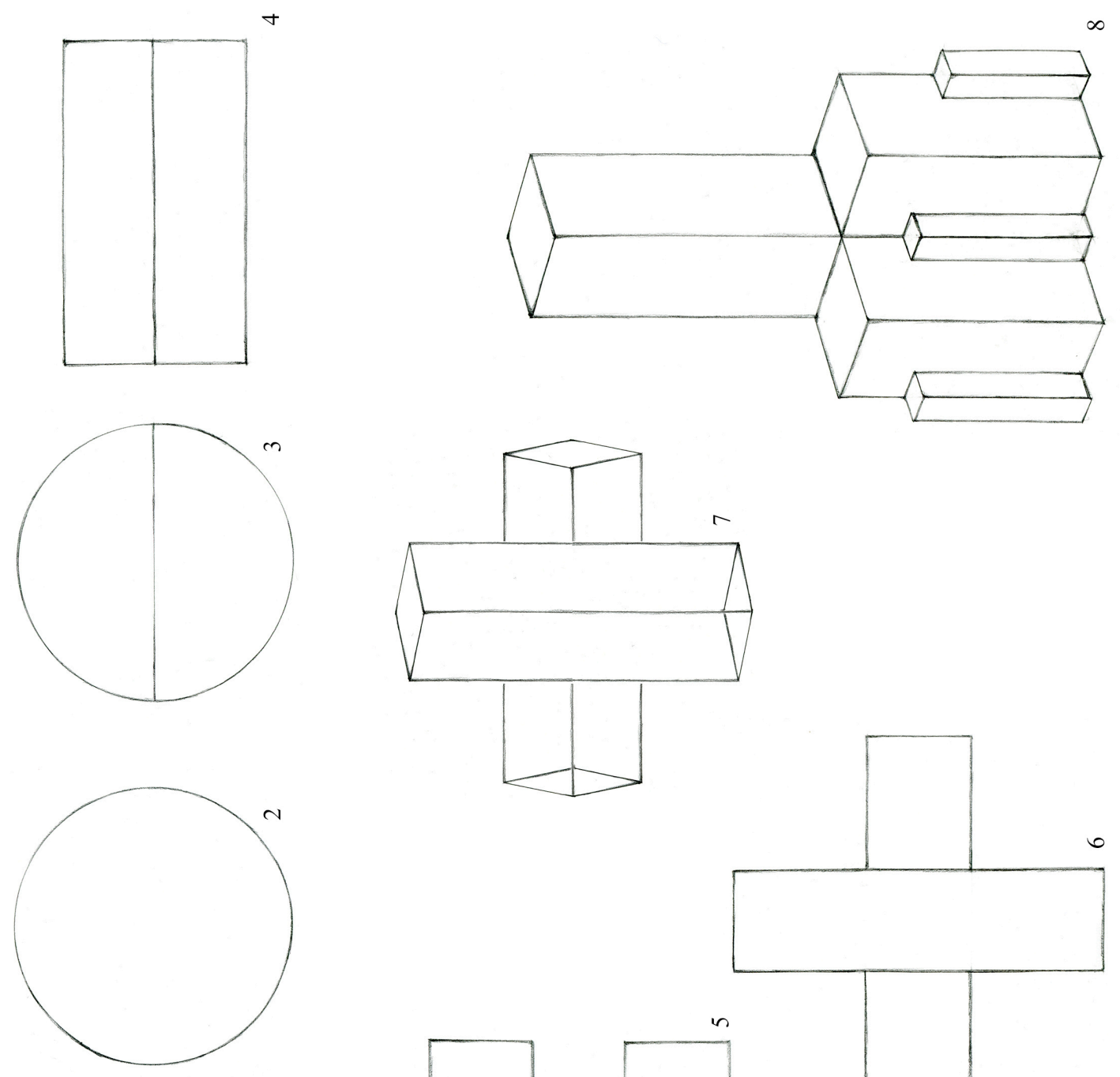

\section{.}




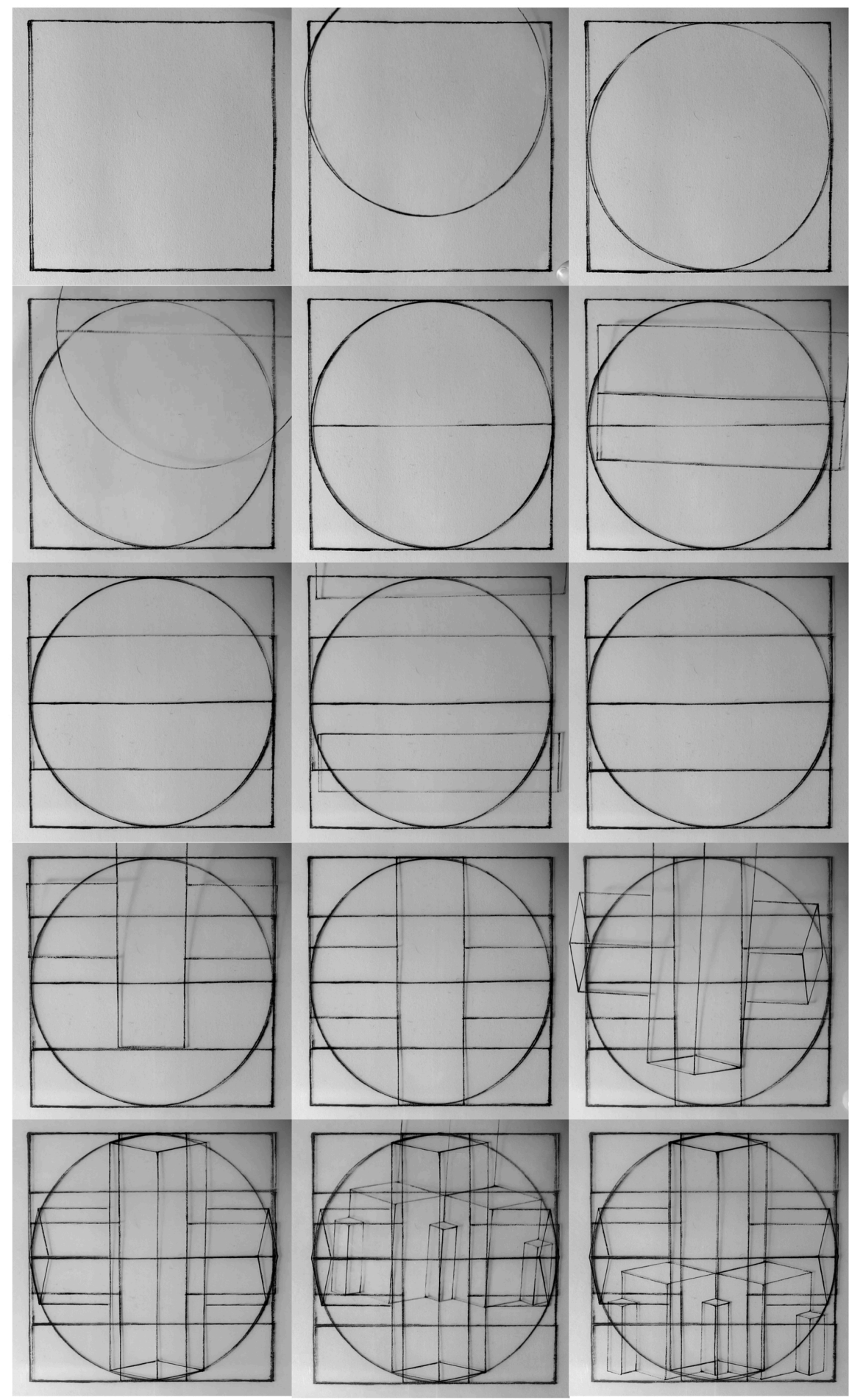

Figure A.2: Stills from the video depicting consecutively overlaid transparencies with drawings of figures from Malevich's script, as seen in Figure A.1. The video can be watched here (password: Malevich): https://vimeo.com/366396037 


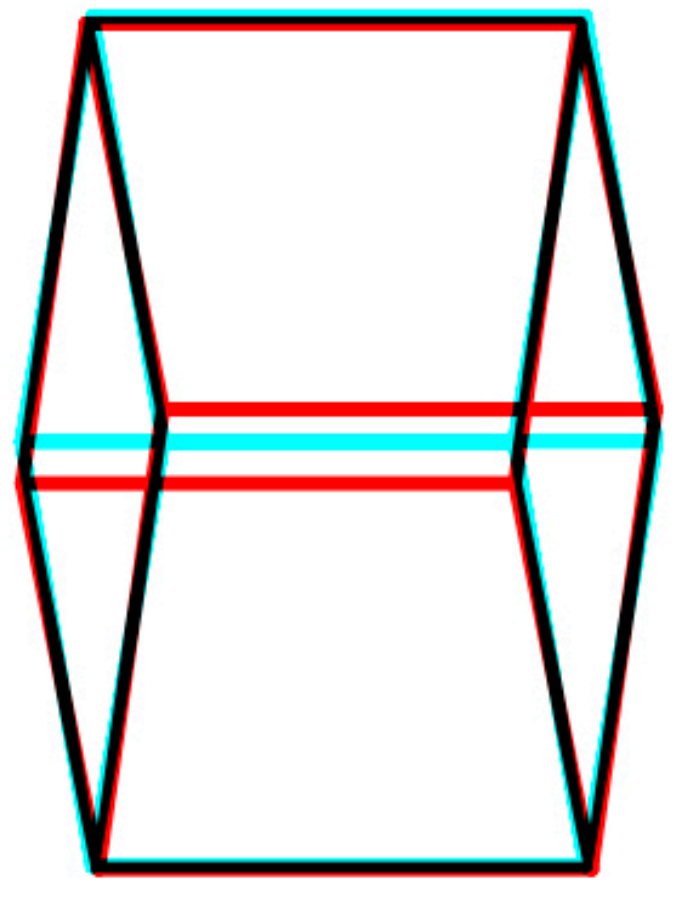

Figure A.3: Cube in anaglyph Stereo 3D (this image is intended to be viewed horizontally through anaglyph glasses to achieve stereographic effect). 


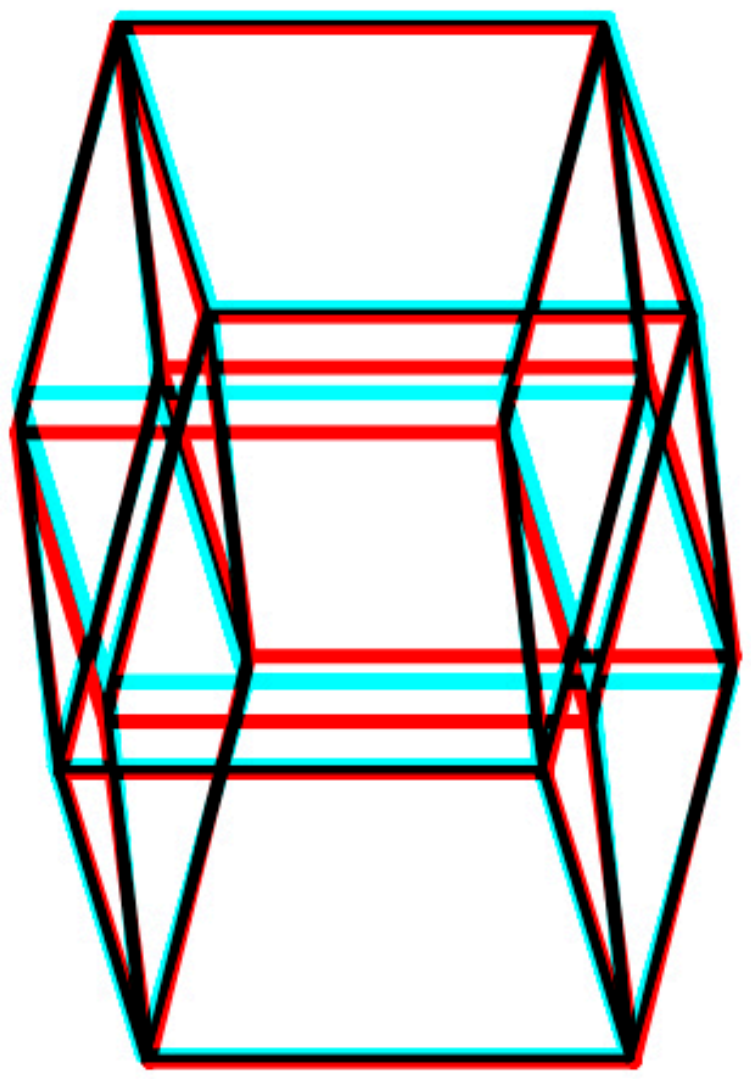

Figure A.4: Four-dimensional cube in anaglyph Stereo 3D (this image is intended to be viewed horizontally through anaglyph glasses to achieve stereographic effect). 


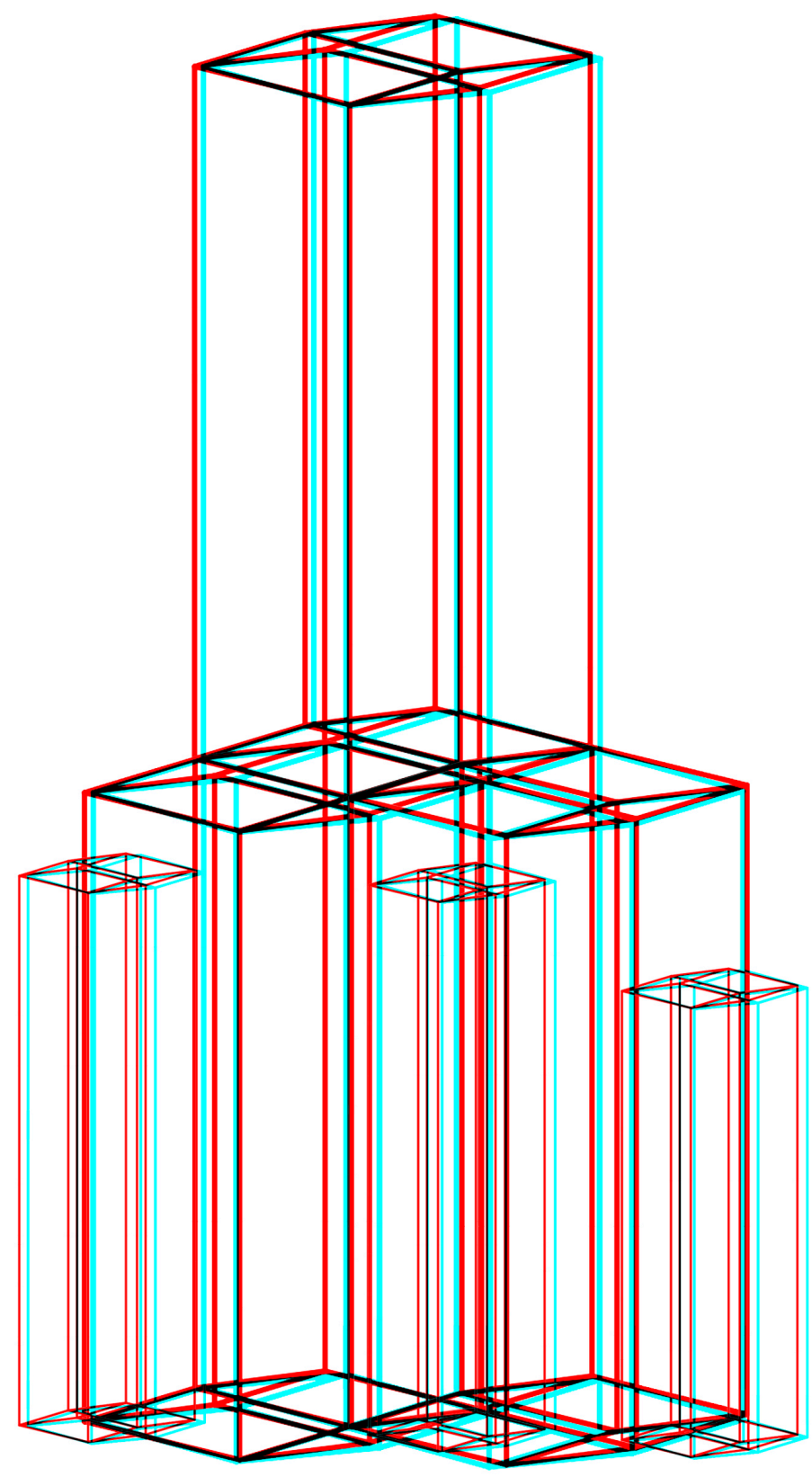

Figure A.5: Four-dimensional architecton in anaglyph Stereo 3D (this image is intended to be viewed through anaglyph glasses to achieve stereographic effect). 


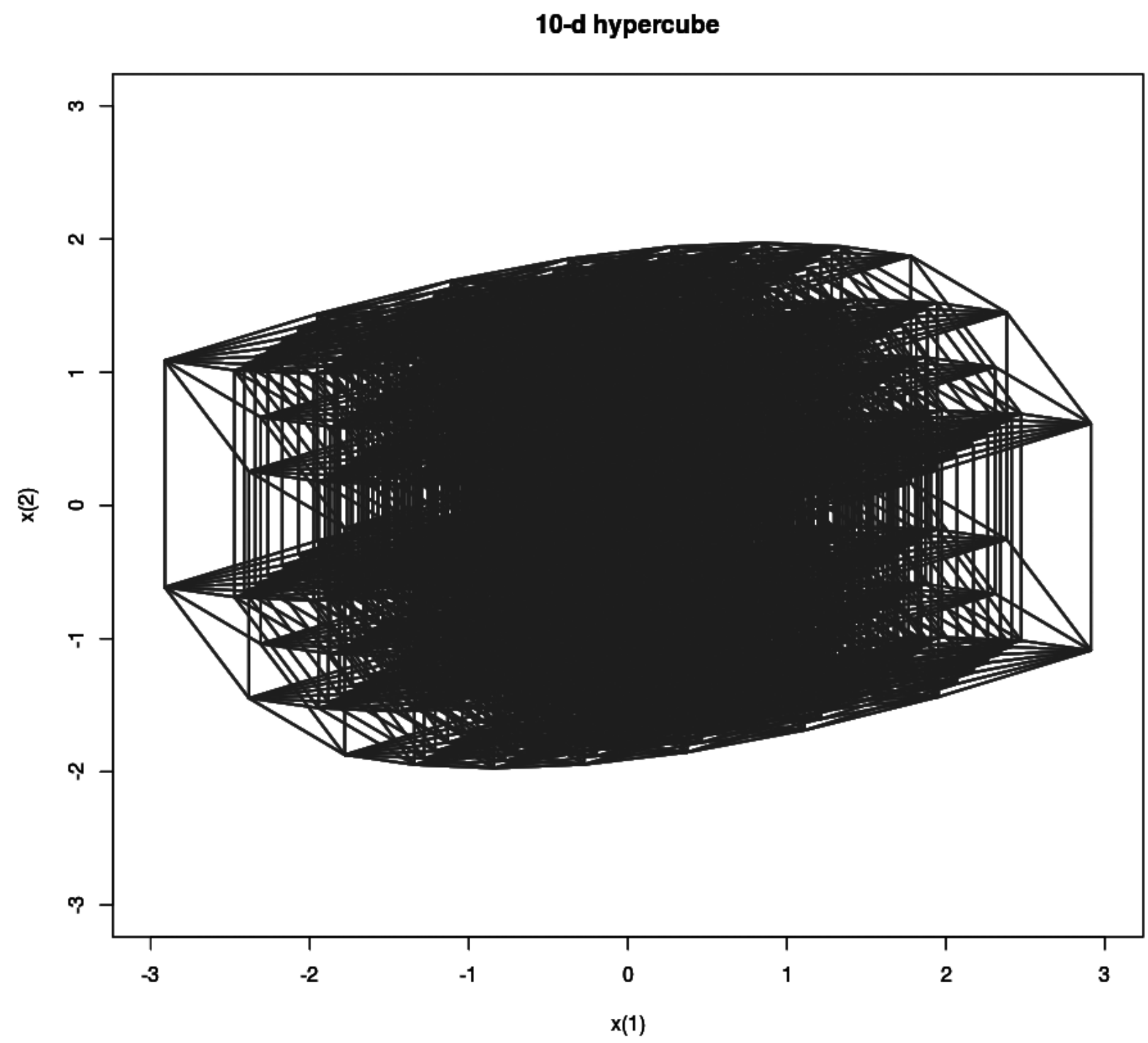

Figure A.6: Ten-dimensional cube. 
Notes on Virtual Reality Project and Anaglyph Stereo Images Inspired by Kazimir Malevich's Film Script

This dissertation's creative component consists of a Virtual Reality project in which one can experience Kazimir Malevich's architecton presented as a projection of a four-dimensional shape onto a three-dimensional environment, a desert created with the use of textures of cracked paint to represent the cracks of the ground. Cracked paint textures are taken from the photographs of Malevich's original paintings' surfaces. My earlier experimentation with Malevich's architecton consisted in attempting to create an anaglyph stereo image of this shape in four dimensions. In this dissertation I included anaglyph stereo images of a cube, a tesseract (a building block from which I formed a four-dimensional architecton), and an architecton. ${ }^{1}$ The latter shape is too complex for viewing using the limited technology of anaglyph stereo $3 \mathrm{D}$, which prompted me to use Virtual Reality (Oculus Rift) to achieve the intended result of experiencing Malevich's shapes as a part of one's sensorium.

\footnotetext{
${ }^{1}$ To generate the cube, the tesseract, and their stereo pairs Darren Wilkinson's code in R was used: https://darrenjw.wordpress.com/2009/11/18/hypercubes-in-r-getting-started-with-programming-in-r/
} 


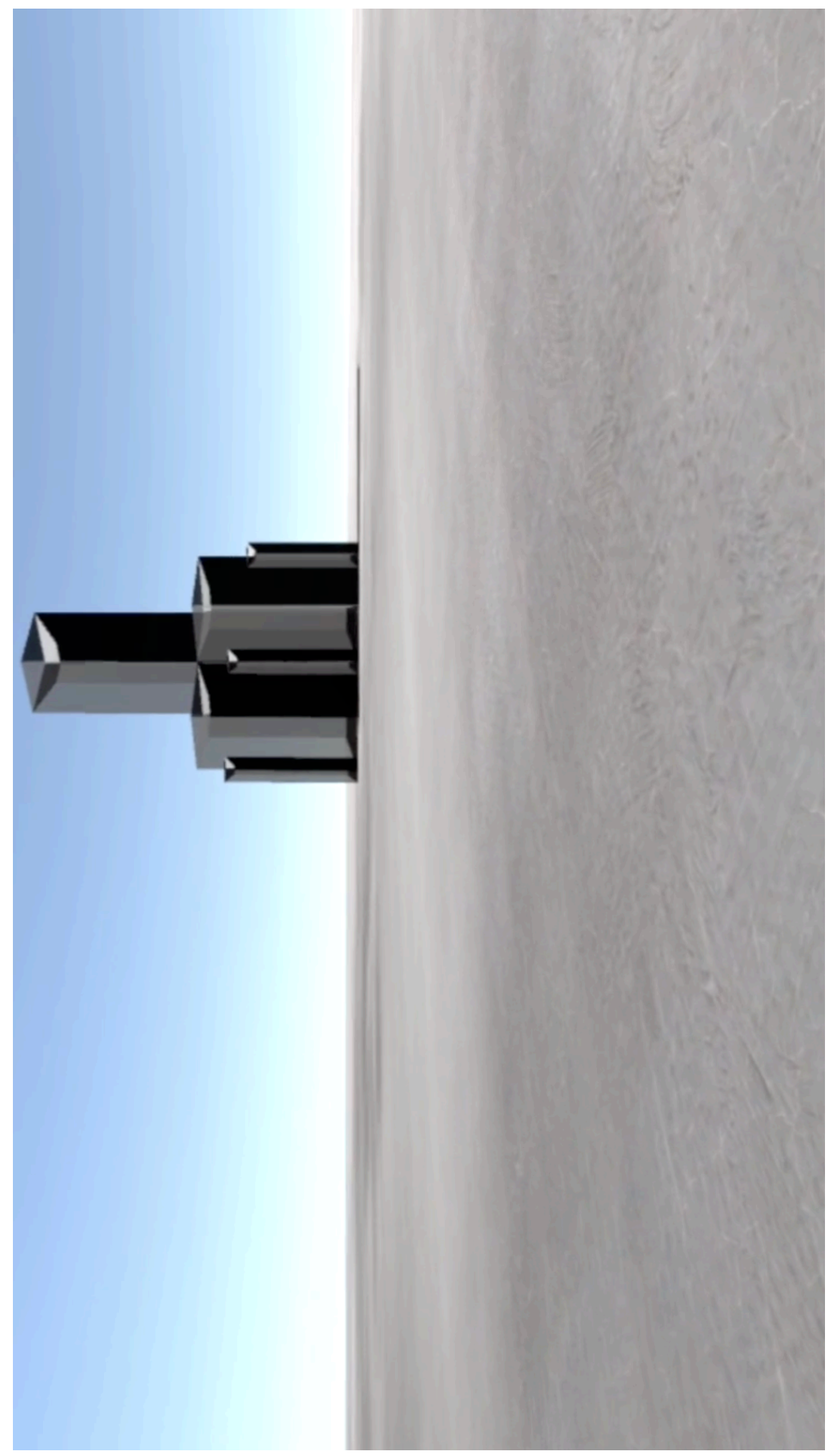

Figure A.7. Screenshot of the Virtual Reality scene of a four-dimensional architecton in a desert, whose surfaces are rendered using photographs of paint cracks from Malevich's paintings. 


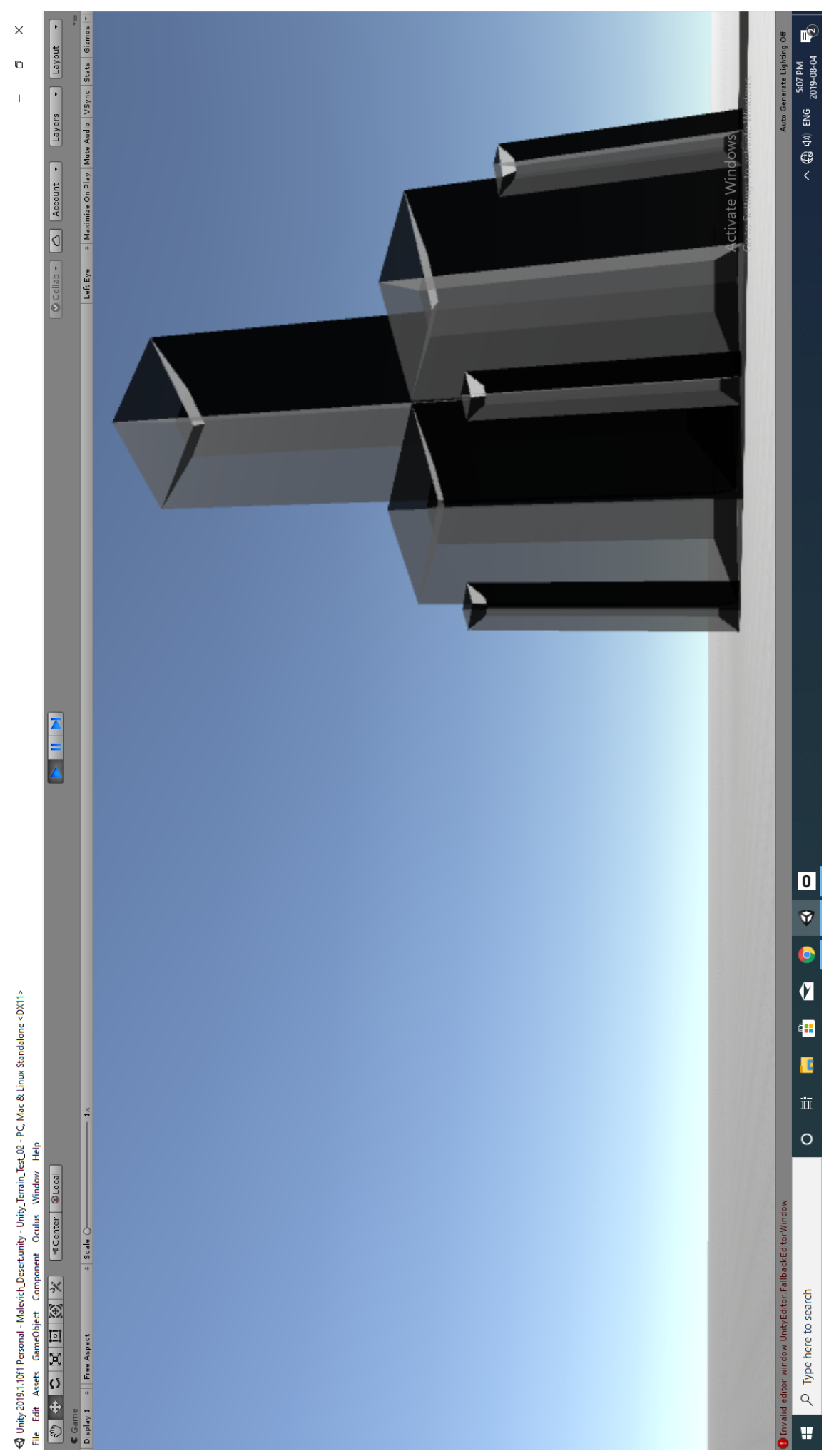

Figure A.8: Screenshot of the Virtual Reality scene of a four-dimensional architecton (close-up) in a desert, whose surfaces are rendered using photographs of paint cracks from Malevich's paintings. 


\section{Bibliography}

Ackermann, Marion, and Isabelle Malz. Kandinsky, Malewitsch, Mondrian: Der weisse Abgrund Unendlichkeit = The Infinite White Abyss. Koln: Snoeck Verlagsgesellschaft mbH, 2014.

Aginskaja, Vera. "Roman Zamjatina My v Kontekste Proizvedenij I Idej Proletkul'ta." Canadian - American Slavic Studies 45 (2011): 367-89.

Alighieri, Dante. The Divine Comedy. Translated by Burton Raffel. Evanston, Illinois:

Northwestern University Press, 2010.

Anonymous. The Upanishads (Penguin Classics). London: Penguin Classics, 1965.

Apollinaire, Guillaume. “On Painting.” In The Cubist Painters, 5-28. Berkeley, CA: University of California Press, 2004.

Barilli, Renato. The Science of Culture and the Phenomenology of Styles. Montréal, Québec: McGill-Queens University Press, 2012.

Bell, Clive. Art. London: Chatto and Windus, 1928.

Bely, Andreï. “Magija slov” [1909]. In Simvolizm Kniga Statej, 316-328. Moskva: Kulturnaâ Revolûciâ, 2010.

Bergson, Henri. The Creative Mind. Translated by Mabelle L. Anderson. Westport, Conn.: Greenwood Press, 1946.

Bergson, Henri. Creative Evolution. Translated by Arthur Mitchel. Mineola, NY: Dover Publications, 1998.

Bergson, Henri. The Two Sources of Morality and Religion. Westport, Conn.: Greenwood Press, 1974.

Bensaude-Vincent, Bernadette. "Revisiting Controversy on Energetics." In Wilhelm Ostwald at the Crossroads Between Chemistry, Philosophy and Media Culture, edited by Britta Görs, 1328. Leipzig: Leipziger Universitätsverlag, 2005.

Benson, Timothy O., and Aleksandra Shatskikh. "Malevich and Richter: An Indeterminate Encounter." October 143 (2013): 52-68.

Besant, Annie Wood. Man and His Bodies. Los Angeles, CA: The Theosophical Publishing House, 1917.

Billington, James H. Ikona i topor: opyt istolkovaniâ istorii russkoj kul'tury. Moskva: VGBIL, 2011. 
Blanning, Tim. The Romantic Revolution: A History. New York: Modern Library, 2012.

Boersma, Linda, Lisa Holden, Lee Mitzman, Sophie Tates and Stedelijk Museum. Kazimir Malevich and the Russian Avant-garde: Featuring Selections from the Khardzhiev and Costakis Collections. Amsterdam: Stedelijk Museum, 2013.

Bogdanov, Alexander. "Celi I Normy Zhizni.” In Russkij Kosmizm, edited by Boris Groys, 262304. Moscow: Ad Marginem Press, 2015.

Bogdanov, A.A. Tektologija: vseobshhaja organizacionnaja nauka, vol. 1. Moscow: Ekonomika, 1989.

Bolzano, Bernard. Paradoxes of the Infinite (Routledge Revivals). New York: Routledge, 2014.

Bowlt, John E. "Esoteric Culture and Russian Society." In The Spiritual in Art: Abstract Painting 1890-1985, edited by Judi Freeman and Maurice Tuchman, 165-83. New York: Abbeville Press, 1986.

Breidert, W. "Berkeley's defence of the infinite God in contrast to the infinite of mathematics." In Mathematics and the Divine: A Historical Study, edited by Luc Bergmans, 499-509. Amsterdam: Elsevier Science, 2005.

Butlerov, Aleksandr. Stat'i po mediumizmu. Sankt-Peterburg: Tip. V. Demakova, 1889.

Carlson, Maria. No Religion Higher than Truth: A History of the Theosophical Movement in Russia, 1875-1922. Princeton: Princeton University Press, 2015.

Carmody, Denise Lardner, and John Tully. Mysticism: Holiness East and West. New York: Oxford University Press, 1996.

Cartier, P., Jean G. Dhombres, Gerhard Heinzmann, and Cédric Villani. Freedom in Mathematics. New Delhi: Springer.

Casteel, Kyle. “Cosmic shape and size.” Astronomy, (Apr. 2012): 51.

Chadaga, Julia. "No Mere Reflection: Mirrors as Windows on Russian Culture." Studies in 20th \& 21 st Century Literature 34, no. 2 (2010): 1-37.

Clarke, Bruce. "From Thermodynamics to Virtuality." In From Energy to Information:

Representation in Science and Technology, Art, and Literature, edited by Bruce Clarke and Linda Dalrymple Henderson, 17-34. Stanford, CA: Stanford University Press, 2002.

Collins, Maynard. Norman McLaren. Ottawa: Canadian Film Institute, 1976.

Coomaraswamy, Ananda Kentish. The Dance of Siva: Essays on Indian Art and Culture. New York (N.Y.): Dover, 1985. 
Coopersmith, Jonathan. Electrification of Russia, 1880-1926. Ithaka, NY: Cornell University Press, 2016.

Crouch, Tom D. Aiming for the Stars: The Dreamers and Doers of the Space Age. Washington: Smithsonian Institution Scholarly Press, 1999.

Darwin, Charles. Charles Darwin on the Origin of Species: The Illustrated Edition. New York: Sterling, 2008.

Dauben, Joseph Warren. Georg Cantor: His Mathematics and Philosophy of the Infinite. Princeton, NJ: Princeton University Press, 1990.

Davidson, Donald. Plato's Philebus. New York: Routledge, 2013.

Dobson, Terence. Film Work of Norman McLaren. Eastleigh: John Libbey Publishing, 2017.

Douglas, Charlotte. "Energetic Abstraction: Ostwald, Bogdanov, and Russian Post-

Revolutionary Art." In From Energy to Information: Representation in Science and Technology, Art, and Literature, edited by Bruce Clarke and Linda Dalrymple Henderson, 76-94. Stanford, CA: Stanford University Press, 2002.

Douglas, Charlotte. "Evolution and the Biological Metaphor in Modern Russian Art." Art Journal 44, no. 2 (1984): 153-61.

Douglas, Charlotte. Swans of Other Worlds: Kazimir Malevich and the Origins of Abstraction in Russia. Ann Arbor, MI: UMI Research Press, 1980.

Eisenstein, Sergei. "Cvet." Izbrannye proizvedenija v shesti tomakh [Selected Writings in Six Volumes], vol. 1, pp. 519-520. Moscow: Iskusstvo, 1964.

Eisenstein, Sergei. Montazh. Moskva: Muzeĭ Kino, 2000.

Eisenstein, Sergei. "Sergei Eisenstein." In Izbrannye proizvedenija $v$ shesti tomakh [Selected Writings in Six Volumes], vol. 1, pp. 84-97. Moscow: Iskusstvo, 1964.

Elder, R. Bruce. Cubism and Futurism: Spiritual Machines and the Cinematic Effect. Waterloo, Ontario: Wilfrid Laurier University Press, 2018.

Elder, R. Bruce. Dada, Surrealism, and the Cinematic Effect. Waterloo, Ont.: Wilfrid Laurier U Press, 2013.

Elder, R. Bruce. "Eisenstein, My Contemporary (review essay)." Canadian Journal of Film Studies 4, no. 2 (Fall, 1995): 33-50. 
Elder, R. Bruce. "Hans Richter and Viking Eggeling: The Dream of Universal Language and the Birth of The Absolute Film." In Avant-garde Film, edited by Alexander Graf and Dietrich Scheunemann, 3-54. New York: Rodopi, 2007.

Elder, R. Bruce. Harmony and Dissent: Film and Avant-garde Art Movements in the Early Twentieth Century. Waterloo, Ont.: Wilfrid Laurier University Press, 2010.

Elder, R. Bruce. "Ejzenstejn, Symbolisme and the Occult." In Filmbuilding. Proceedings of Filmbuilding (published as a CD ROM), Ryerson University, Toronto, 1-24.

Fedorov, Nikolaĭ Fedorovich, and S. G. Semenova. Sochineniิia. Moskva: Mysl', 1982.

Fedorov, Nikolaĭ Fedorovich. Filosofîia obshchago diela: stat'i, mysli i pi'sma. vol. 2. Viernyŭ: Tip. Semiriechenskago obl. pravleniia, 1913.

Ferguson, John. An Illustrated Encyclopaedia of Mysticism and the Mystery Religions. London: Thames and Hudson, 1976.

Fink, Hilary L. Bergson and Russian Modernism: 1900-1930. Evanston: Northwestern University Press, 2012.

Firtich, Nikolai. 'Rejecting 'The Sun of Cheap Appearances': Journey Beyond 'Zero' with Kručenych, Malevič, Belyj, Jakobson and Jean-Luc Godard.' Russian Literature 65, no. 1-3 (2009): 355-78.

Florensky, Pavel. Mnimosti v Geometrii (Imaginaries in Geometry). Moscow: Lazur’, 1991.

Florensky, Pavel. "On the Symbols of the Infinite (An Outline of G. Cantor's Ideas)" [1904]. Sobranie sochinenii v chetyreh tomakh [Collected Works in Four Volumes], vol. 1, 79-128. Moscow: Mysl', 1994.

Florensky, Pavel. "Organ Projection” [1917]. Sobranie sochinenii v chetyreh tomakh [Collected Works in Four Volumes], vol. 3 (part 1), 400-421. Moscow: Mysl', 2000.

Forman, Robert K. C. Mysticism, Mind, Consciousness. New York: State University of New York Press, 1999.

Friedrich Zöllner, Johann Carl. Transcendental Physics: An Account of Experimental Investigations from The Scientific Treatises of Johann Carl Friedrich Zöllner. London: W.H. Harrison, 1880.

Gippius, Z. N. Poslednie Zhelaniia: Povesti, Rasskazy, Ocherki. Moscow: Intelvak, 2006.

Gould, Glenn, with Norman McLaren. "Where Music \& Film Meet: Glenn Gould in Conversation with Norman McLaren." Glenn Gould Foundation's Magazine 8.1 (Spring 2002): $12-18$. 
Graça, Marina Estela. Cinematic Motion by Hand. Society for Animation Studies Conference, Dresden, April 13-15, 2005, 1-10.

Graham, Loren R., and Jean-Michel Kantor. Naming Infinity: A True Story of Religious Mysticism and Mathematical Creativity. Cambridge: The Belknap Press of Harvard U Press, 2009.

Griffiths, Paul J. "Pure Consciousness and Indian Buddhism." In The Problem of Pure Consciousness: Mysticism and Philosophy, edited by Robert K. C. Forman, 71-97. New York, Oxford: Oxford University Press, 1990.

Grillaert, Nel. "Orthodoxy Regained: The Theological Subtext in Dostoevskijs 'Dream of a Ridiculous Man'.” Russian Literature 62, no. 2 (2007): 155-73.

Gnedenko, B. V., and S. S. Demidov. Ocherki po istorii matematiki v Rossii. Moskva: OGIZ Gosudarstvennoe Izdatel'stvo Tehniko-Teoreticheskoj Literatury, 1946.

Goscilo, Helena. "The Mirror in Art: Vanitas, Veritas, and Vision." Studies in 20th \& 21st Century Literature 34, no. 2 (2010): 1-38.

Gough, Maria. “Architecture as Such.” In Malevich, edited by Achim Borchardt-Hume, 158163. London: Tate Modern, 2015.

Hamilton, William Rowan. Elements of Quaternions. London: Longmans, Green \& Co., 1866.

Henderson, Linda Dalrymple. The Fourth Dimension and non-Euclidean Geometry in Modern Art. Cambridge, MA: MIT Press, 2013.

Herbert, Robert, ed. Modern Artists on Art: Ten Unabridged Essays. Nueva Jersey (Estados Unidos): Prentice-Hall, 1964.

Hinton, Charles Howard. Speculations on the Fourth Dimension: Selected Writings of Charles Hinton. New York, NY: Dover Publications, 1980.

Hinton, Charles Howard. A New Era of Thought. London: Swan Sonnenschein \& Co., 1888.

Horrocks, Roger. Len Lye: A Biography. Auckland: Auckland University Press, 2002.

Huxley, Aldous. Ends and Means. London: Chatto \& Windus, 1946.

James, William. The Varieties of Religious Experience: A Study in Human Nature, Being the Gifford Lectures on Natural Religion Delivered at Edinburgh in 1901-1902, by William James. New York, London, Bombay, Calcutta, and Madras: Longmans, Green \& Co, 1917.

Janiak, Andrew. Newton as Philosopher. New York: Cambridge University Press, 2008. 
Janiak, Andrew. Newton. Chichester, West Sussex: Wiley Blackwell, 2015.

Kapp, Ernst. Grundlinien einer Philosophie der Technik. Braunschweig: George Westermann, 1877.

Khardzhiev-Chaga Collection. Document H_0759. Stedelijk Museum Amsterdam, translation mine.

Khardzhiev-Chaga Collection. Document H_0756, p. 3. Stedelijk Museum Amsterdam, translation mine.

Khardzhiev-Chaga Collection. Document H_0761. Stedelijk Museum Amsterdam, translation mine.

Khardzhiev-Chaga Collection. Document H_758. Stedelijk Museum Amsterdam.

Khardzhiev-Chaga Collection. Document H_0762. Stedelijk Museum Amsterdam.

Khlebnikov, Velimir, M. Poliakov, V. P. Grigor'ev, and A. E. Parnis, "Us and Buildings" [1915]. In Tvoreniia, 595-602. Moskva: Sov. Pisatel', 1986.

Kocho-Williams, Alastair. Russia's International Relations in the Twentieth Century. Routledge, 2013.

Kolmogorov, A. N., and A. P. IUshkevich. Mathematics of the 19th Century: Mathematical Logic, Algebra, Number Theory, Probability Theory. Basel: Birkhäuser Verlag, 2001.

Kolobaeva, L. A. Russkiı simvolizm. Moskva: Izd-vo Moskovskogo universiteta, 2000.

Koyre, Alexander. From the Closed World to the Infinite Universe. Radford, VA: Wilder Publications, 2007. Kindle edition.

Kruchenykh, Aleksei, and Mikhail Matyushin. Pobeda Nad Solnzem (Victory Over the Sun). Sankt-Peterburg: Tipografiya Tov-va "Svet," 1913.

Krupskaja, Nadezhda. Osnovy politiko-prosvetitel'noj raboty. Moscow: Direct-Media, 2014.

Kuznetsov, S. A. Bolshoi tolkovyi slovar russkogo iazyka. Sankt-Peterburg: Norint, 2000.

Lawton, Anna. The Red Screen: Politics, Society, Art in Soviet Cinema. London: Routledge, 1992.

Leadbeater, Charles W. "The Fourth Dimension.” Lecture, Amsterdam, April 1900 (A lecture given by C. W. Leadbeater before the Amsterdam Lodge T.S. in April, 1900. Stenographic notes in Dutch by J.J. Hallo, Jr.; translated into English by Mrs. Marie Knothe). 
Levey, Samuel. "Leibniz on Mathematics and the Actually Infinite Division of Matter." The Philosophical Review 107, no. 1 (January 1998): 49-96.

Lopatin, L. M. “The Philosophy of Vladimir Soloviev.” Mind: A Quarterly Review of Psychology and Philosophy XXV, no. 100 (October 1916): 425-60.

Lorand, Ruth. "Bergson's Concept of Art." British Journal of Aesthetics 39, no. 4 (October 1999): 400-15.

Luecking, Stephen. "A Man and his Square: Kasimir Malevich and the Visualization of the Fourth Dimension.” Journal of Mathematics and the Arts 4, no. 2 (2010): 87-100.

Malevich, Kazimir. "1/40 Painterly Experience” [around 1923]. In Sobranie sochinenii v piati tomakh [Collected Works in Five Volumes], vol. 4, 25-47. Moscow: Gileia, 1995-2004.

Malevich, Kazimir. "1/47. Suprematism. The World as Non-Objectivity" [1924]. In Sobranie sochinenii v piati tomakh [Collected Works in Five Volumes], vol. 4, 156-198. Moscow: Gileia, 1995-2004.

Malevich, Kazimir. "And Faces Rejoice on the Screens: In Order of Discussion" [1925]. Sobranie sochinenii v piati tomakh [Collected Works in Five Volumes], vol.1, p. 289-294. Moscow: Gileia, 1995-2004.

Malevich, Kazimir. "A Note around 1914." In Sobranie sochinenii v piati tomakh [Collected Works in Five Volumes], vol. 5, 384. Moscow: Gileia, 1995-2004.

Malevich, Kazimir. "A Note on the Limits of Reality" [1919-1922]. In Sobranie sochinenii v piati tomakh [Collected Works in Five Volumes], vol. 5, 191-194. Moscow: Gileia, 1995-2004.

Malevich, Kazimir. "Artistic and Scientific Film-Painting and Architectural ConcernsApproaching the New Plastic Architectural System” [1927]. In Sobranie sochinenii v piati tomakh [Collected Works in Five Volumes], vol. 5, 307-313. Moscow: Gileia, 1995-2004.

Malevich, Kazimir. "Exhibition of the Professional Union of Painters. Left Federation (young faction)" (1918). In Sobranie sochinenii v piati tomakh [Collected Works in Five Volumes], vol. 1, 117-123. Moscow: Gileia, 1995-2004.

Malevich, Kazimir. "Form, Color, and Sensation" [1928]. In Sobranie sochinenii v piati tomakh [Collected Works in Five Volumes], vol. 1, 311-321. Moscow: Gileia, 1995-2004.

Malevich, Kazimir. "From Cubism to Suprematism: New Painterly Realism [1915]. In Sobranie sochinenii v piati tomakh [Collected Works in Five Volumes], vol. 1, 27-34. Moscow: Gileia, 1995-2004. 
Malevich, Kazimir. "From Cubism and Futurism to Suprematism: New Realism" [1915]. In Sobranie sochinenii v piati tomakh [Collected Works in Five Volumes], vol. 1, p. 35-55. Moscow: Gileia, 1995-2004.

Malevich, Kazimir. "Futurism, Kinetic and Dynamic" [1929]. In Sobranie sochinenii v piati tomakh [Collected Works in Five Volumes], vol. 2, 226-237. Moscow: Gileia, 1995-2004.

Malevich, Kazimir. "God is not Cast Down: Art, Church, and Factory" [1920]. In Sobranie sochinenii v piati tomakh [Collected Works in Five Volumes], vol.1, 236-265. Moscow: Gileia, 1995-2004.

Malevich, Kazimir. "I arrived” [1918]. In Sobranie sochinenii v piati tomakh [Collected Works in Five Volumes], vol. 1, 108-109. Moscow: Gileia, 1995-2004.

Malevich, Kazimir. "Introduction to the Theory of the Additional Element in Painting" [1923]. In Sobranie sochinenii v piati tomakh [Collected Works in Five Volumes], vol. 2, 55-104.

Moscow: Gileia, 1995-2004.

Malevich, Kazimir. "Laziness_-The Real Truth of Humankind" [1921]. In Sobranie sochinenii v piati tomakh [Collected Works in Five Volumes], vol. 5, 178-187. Moscow: Gileia, 1995-2004.

Malevich, Kazimir. "Letters: K. S. Malevich to M. O. Gershenzon (1918-1924).” In Sobranie sochinenii v piati tomakh [Collected Works in Five Volumes], vol.3, 327-354. Moscow: Gileia, 1995-2004.

Malevich, Kazimir. "Light and Colour." In Sobranie sochinenii v piati tomakh [Collected Works in Five Volumes], vol. 4, 239-272. Moscow: Gileia, 1995-2004.

Malevich, Kazimir. "New Art and the Art of Representation" [1928]. In Sobranie sochinenii v piati tomakh [Collected Works in Five Volumes], vol. 2, 154-176. Moscow: Gileia, 1995-2004.

Malevich, Kazimir. “On Developers: Posters” [1925]. Sobranie sochinenii v piati tomakh [Collected Works in Five Volumes], vol.1, p. 283-288. Moscow: Gileia, 1995-2004.

Malevich, Kazimir. "On New Systems in Art” [1919]. In Sobranie sochinenii v piati tomakh [Collected Works in Five Volumes], vol. 1, 153-184. Moscow: Gileia, 1995-2004.

Malevich, Kazimir. "Our Time is the Age of Analysis..." [1921]. In Sobranie sochinenii v piati tomakh [Collected Works in Five Volumes], vol. 2, 30. Moscow: Gileia, 1995-2004.

Malevich, Kazimir. "Questions" [1916-1918]. In Sobranie sochinenii v piati tomakh [Collected Works in Five Volumes], vol. 5, 63-66. Moscow: Gileia, 1995-2004. 
Malevich, Kazimir. Sobranie sochinenii v piati tomakh [Collected Works in Five Volumes]. Moscow: Gileia, 1995-2004.

Malevich, Kazimir. "Suprematism. 34 Drawings” [1920]. In Sobranie sochinenii v piati tomakh [Collected Works in Five Volumes], vol. 1, 185-207. Moscow: Gileia, 1995-2004.

Malevich, Kazimir. "Suprematism (From the 1915-1920 Works)" [1925]. In Sobranie sochinenii v piati tomakh [Collected Works in Five Volumes], vol. 2, 33-35. Moscow: Gileia, 1995-2004.

Malevich, Kazimir. "Suprematism. From 'The Catalog of the Tenth State Exhibition. Nonobjective Creation and Suprematism"' [1919]. In Sobranie sochinenii v piati tomakh [Collected Works in Five Volumes], vol.1, 150-152. Moscow: Gileia, 1995-2004.

Malevich, Kazimir. "'Supremus.' Cubism and Futurism” [1916-1918]. In Sobranie sochinenii v piati tomakh [Collected Works in Five Volumes], vol. 5, 40-53. Moscow: Gileia, 1995-2004.

Malevich, Kazimir. "Suprematism as Pure Knowledge" [1922]. In Sobranie sochinenii v piati tomakh [Collected Works in Five Volumes], vol. 3, 69-216. Moscow: Gileia, 1995-2004.

Malevich, Kazimir. "The Answer to the Two Socialists" [1918-1919]. In Sobranie sochinenii v piati tomakh [Collected Works in Five Volumes], vol. 5, 112-118. Moscow: Gileia, 1995-2004.

Malevich, Kazimir. "The World as Non-Objectivity. Part II. Suprematism as Non-Objectivity" [1922]. In Sobranie sochinenii v piati tomakh [Collected Works in Five Volumes], vol. 3, 218324. Moscow: Gileia, 1995-2004.

Malevich, Kazimir. "The World as Non-Objectivity. Part II: Suprematism" [1927]. In Sobranie sochinenii v piati tomakh [Collected Works in Five Volumes], vol. 2, 105-123. Moscow: Gileia, 1995-2004.

Malevich, Kazimir. "The World as Non-Objectivity (Fragments)" [1926]. In Sobranie sochinenii v piati tomakh [Collected Works in Five Volumes], vol. 2, 36-50. Moscow: Gileia, 1995-2004.

Malevich, Kazimir. "Tsvetopis' [neologism that can be roughly translated as 'Color-writing']" [1916-1918]. In Sobranie sochinenii v piati tomakh [Collected Works in Five Volumes], vol. 5, 67-69. Moscow: Gileia, 1995-2004.

Malevich, Kazimir. "To the State Workers from Art" [1918]. In Sobranie sochinenii v piati tomakh [Collected Works in Five Volumes], vol.1, 75-87. Moscow: Gileia, 1995-2004.

Malevich, Kazimir. "Turning-Point" [1918]. In Sobranie sochinenii v piati tomakh [Collected Works in Five Volumes], vol.1, 104-107. Moscow: Gileia, 1995-2004.

Malevich, Kazimir. The Non-Objective World. Chicago: Paul Theobald and Company, 1959. 
Malevich, Kazimir. "Letter from Malevich to S. M. Eisenstein, 13 August 1928, Tarasovka." In Malevich o Sebe, Sovremenniki o Maleviche: Pis'ma, Dokumenty, Vospominaniia, Kritika: V 2kh Tomakh, edited by Vakar, I. A., and T. N. Mikhienko, vol. 1, 200-201. Moscow: RA, 2004.

Malevich, Kazimir. "Letter from Malevich to El Lissitzky, 14 August 1924, Nemchinovo.” In Malevich o Sebe, Sovremenniki o Maleviche: Pis'ma, Dokumenty, Vospominaniia, Kritika: V 2kh Tomakh, edited by Vakar, I. A., and T. N. Mikhienko, vol. 1, 160-161. Moskva: RA, 2004.

Malevich, Kazimir. "Letter from Malevich to M. Matyushin, prior to 23 June 1916, Kunzevo.” In Malevich o Sebe, Sovremenniki o Maleviche: Pis'ma, Dokumenty, Vospominaniia, Kritika: V 2kh Tomakh, edited by Vakar, I. A., and T. N. Mikhienko, vol. 1, 87-90. Moskva: RA, 2004.

Malevich, Kazimir. "Letter from Malevich to N. M. Suetin and V. T. Vorob'ev [Sometime between 21 and 28 February 1927, Moscow]." In Malevich o Sebe, Sovremenniki o Maleviche: Pis'ma, Dokumenty, Vospominaniia, Kritika: V 2-kh Tomakh, edited by Vakar, I. A., and T. N. Mikhienko, vol. 1, 184. Moskva: RA, 2004.

Mcginn, Bernard. "Mystical Language in Meister Eckhart and His Disciples." Medieval Mystical Theology 21, no. 2 (2012): 214-32.

McLuhan, Marshall. Understanding Media: The Extensions of Man. Cambridge, MA: MIT Press, 1994.

McLuhan, Marshall. The Gutenberg Galaxy: The Making of Typographic Man. Toronto: University of Toronto Press, 1962.

McLaren, Norman, and Michael White. The Drawings of Norman McLaren = Les Dessins De Norman McLaren. Montreal: Tundra Books, 1975.

McWilliams, Donald, with Norman McLaren. "Talking to a Great Artist: Norman McLaren Interviewed by Don McWilliams.” McGill Reporter 1.35 (1969): 3-5.

Milner, John. "Malevich: Becoming Russian.” In Malevich, edited by Achim Borchardt-Hume, 34-65. London: Tate Publishing, 2014.

Milner, John. Kazimir Malevich and the Art of Geometry. New Haven: Yale University Press, 1996.

Nahin, Paul J. An Imaginary Tale: The Story of $\sqrt{ }-1$. Princeton, NJ: Princeton University Press, 2016.

Obolevitch, Teresa. "All-Unity According to V. Soloviev and S. Frank. A Comparative Analysis." Forum Philosophicum 15, no. 2 (2010): 413-25.

Oleksyuk, A. "Filosofiya Imeni P.A. Florenskogo [P.A. Florensky’s Philosophy of Name]." Vestnik MGOU "Filosofskie Nauki" 4 (2009): 164-69.

Ostwald, Wilhelm. "The Modern Theory of Energetics.” Monist 17, no. 4 (1907): 481-515. 
Partridge, Eric. Origins: A Short Etymological Dictionary of Modern English. London: Routledge \& Kegan Paul, 1966.

Paul, Diane. "Eugenics and the Left.” Journal of the History of Ideas 45, no. 4 (1984): 567-590.

Plato: Parmenides. The Dialogues of Plato: Translated into English, with Analyses and Introductions. Translated by Benjamin Jowett. New York: Macmillan and Co., 1892.

Plotnitsky, Arkady. "Bernhard Riemann's Conceptual Mathematics and the Idea of Space." Configurations 17, no. 1 (2009): 105-30.

Pound, Ezra. “A Stray Document.” In Make it New: Essays by Ezra Pound, 335-341. London: Faber and Faber Limited, 1934.

Purves, Mark and Rob McFarland. "Biographie: Hans Richter." In Hans Richters Rhythmus 21: Schlüsselfilm Der Moderne, 19-32. Würzburg: Königshausen \& Neumann, 2012.

Richter, Hans. Encounters from Dada till Today. Munich: Prestel, 2013, Kindle Edition.

Richter, Hans. Dada: Art and Anti-art: With 188 Illustrations. London: Thames \& Hudson, 1997.

Richter, Hans. The Struggle for the Film. New York: St. Martin's Press, 1986.

Robbin, Tony. Shadows of Reality: The Fourth Dimension in Relativity, Cubism, and Modern Thought. New Haven: Yale University Press, 2006.

Rosenthal, Bernice Glatzer. "Fashionable Occultism: Spiritualism, Theosophy, Freemasonry, and Hermeticism in Fin-de-Siècle Russia." In The Occult in Russian and Soviet Culture, edited by Bernice Glatzer Rosenthal, 135-152. Ithaca, NY: Cornell University Press, 1997.

Rucker, Rudy V. B. Infinity and the Mind: The Science and Philosophy of the Infinite. Princeton, NJ: Princeton U Press, 2005.

Russ, Steve. The Mathematical Works of Bernard Bolzano. Oxford: Oxford University Press, 2004.

Scanlan, James P. “A. F. Losev and Mysticism in Russian Philosophy.” Studies in East European Thought. 46, no. 4 (1994): 263-86.

Scriba, Christoph J., Peter Schreiber, and Jana Schreiber. 5000 Years of Geometry: Mathematics in History and Culture. Basel: Birkhäuser, 2015.

Shatskikh, Alexandra. "Malevich and Film." The Burlington Magazine 135, no. 1084 (July 1993): 470-78. 
Shatskikh, Alexandra. Vitebsk: The Life of Art. New Haven: Yale University Press, 2007.

Shaw, George Bernard. Revolutionist's Handbook and Pocket Companion. Salt Lake City: Project Gutenberg, 2008, Kindle Edition.

Siddiqi, Asif A. The Red Rockets' Glare: Spaceflight and the Soviet Imagination, 1857-1957. Cambridge, MA: Cambridge University Press, 2013.

Smith, Crosbie. "Force, Energy, and Thermodynamics." In The Cambridge History of Science, vol. 5, edited by Mary Jo Nye, 289-310. Cambridge, MA: Cambridge University Press, 2002.

Smith, Michael J. “Aristotle on the Infinite, Space, and Time.” In A Companion to Aristotle, edited by Georgios Anagnostopoulos, 260-276. Oxford: Wiley-Blackwell, 2013.

Smith, Oliver. Vladimir Soloviev and the Spiritualization of Matter. Boston: Academic Studies Press, 2011.

Sochor, Zenovia A. Revolution and Culture: The Bogdanov-Lenin Controversy. Ithaca (N.Y.): Cornell University Press, 1988.

Soloviev, V.S, and Judith Deutsch. Kornblatt. Divine Sophia: The Wisdom Writings of Vladimir Solovyov. Ithaca: Cornell University Press, 2009.

Soloviev, Vladimir. "The General Meaning of Art.” Library of Russian Religious, Philosophical, and Artistic Literature. Accessed September 19, 2017, 9 pages.

http://www.vehi.net/soloviev/smysl_isk.html.

Soloviev, Vladimir. Readings on Godmanhood. Moscow: Prospekt, 2014.

Stace, W. T. Mysticism and Philosophy. London: Macmillan \& Co, 1961.

Stewart, Janet. "Sociology, Culture and Energy: The Case of Wilhelm Ostwald's 'Sociological Energetics' - A Translation and Exposition of a Classic Text." Cultural Sociology 8, no. 3 (2014): 333-50.

Stites, Richard. Revolutionary Dreams: Utopian Vision and Experimental Life in the Russian Revolution. New York: Oxford University Press, 1989.

Stoeber, Michael. "Mystical Concepts, Artistic Contexts." In Mystical Landscapes: From Vincent van Gogh to Emily Carr, edited by Katharine Lochnan and Roald Nasgaard, 45-57. Munich: DelMonico Books Prestel, 2017.

Thiele, R. "Georg Cantor (1845-1918)." In Mathematics and the Divine: A Historical Study, edited by Luc Bergmans, 523-548. Amsterdam: Elsevier Science, 2005. 
Thomson, William. "On the Dynamic Theory of Heat. Part V. Thermo-electric

Currents." Transactions of the Royal Society of Edinburgh 21 (1857): 123-71.

Tsiolkovsky, Konstantin. “Issledovanie Mirovyh Prostranstv Reaktivnymi Priborami.” Nauchnoe Obozrenie, no. 5 (May 31, 1903): 45-75.

Tsiolkovsky, K. Kosmicheskaia filosofiia. Moskva: Sfera, 2004.

Tsivian, Yuri. Early Cinema in Russia and Its Cultural Reception. London: Routledge, 2015.

Tubbs, Robert. What Is a Number?: Mathematical Concepts and Their Origins. Baltimore: Johns Hopkins University Press, 2009.

Tupitsyn, Margarita. Malevich and Film. New Have: Yale University Press, 2002.

Uspenskiı̌, P. D. Tertium Organum. Sankt-Peterburg: Trud, 1911.

Uspenskiū, P. D. Tertium Organum: The Third Canon of Thought; A Key to the Enigmas of the World. Translated by Claude Fayette Bragdon and Nicholas Bessaraboff. New York: Alfred A. Knopf, 1922.

Vaingurt, Julia. Wonderlands of the Avant-Garde: Technology and the Arts in Russia of the 1920s. Evanston, IL: Northwest University Press, 2017.

Vestnik opytnoj fiziki i jelementarnoj matematiki (V.O.F.Je.M.) Archive 1886-1917. Version 1.00 Full DVD Edition, Multimedia Disk, Matematicheskij institut RAN im. Steklova, 2011.

Wade-Matthews, Max and Wendy Thompson. The Encyclopedia of Music: Instruments of the Orchestra and the Great Composers. London: Natl Book Network, 2005.

Waldegg, Guillermina. "Bolzano's Approach to the Paradoxes of Infinity: Implications for Teaching." Science \& Education 14, no. 6 (2005): 559-77.

Youngblood, Denise Jeanne. Soviet Cinema in the Silent Era, 1918-1935. Austin: University of Texas Press, 1991.

Yount, David J. Plotinus the Platonist: A Comparative Account of Plato and Plotinus' Metaphysics. London: Bloomsbury Academic, 2016.

Zenkovsky, Vasily Vasilyevich. A History of Russian philosophy, vol. 1. Translated by G. L. Kline. London: Routlegde \& Paul, 1953. 